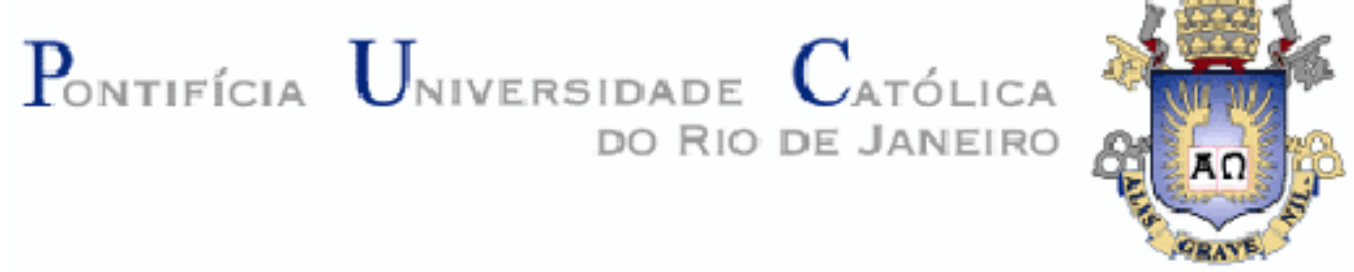

Flavia Guerra Cavalcanti

\title{
União Europeia e América Latina: Associação estratégica ou oposição hierárquica ? \\ Uma análise do discurso
}

Tese de Doutorado

Tese apresentada ao Programa de Pós-Graduação em Relações Internacionais da PUC-Rio como requisito parcial para obtenção do título de Doutor em Relações Internacionais.

Orientador: Prof. José María Gómez

Rio de Janeiro

Agosto de 2012 


\title{
Pontifícia $U_{\text {miversidade }}$ Católlica $_{\text {a }}$

Flavia Guerra Cavalcanti

\author{
União Europeia e América Latina: \\ Associação estratégica ou oposição \\ hierárquica? Uma análise do discurso
}

Tese apresentada como requisito parcial para ob tenção do grau de Doutora pelo Programa de Pós-Graduação em Relações Internacionais da PUC-Rio. Aprovada pela Comissão Examinadora abaixo assinada.

Prof. José María Gómez Orientador Departamento de Relações Internacionais - PUC-Rio

Prof. Paulo César Duque-Estrada Departamento de Filosofia - PUC-Rio

Prof. Giuseppe Cocco Escola de Comunicação/UFRJ

Prof. Paulo Luiz Moreaux Lavigne Esteves Departamento de Relações Internacionais - IRI-PUC-Rio

Prof. Rafael Antonio Duarte Villa Universidade de São Paulo (USP).

Profa. Mônica Herz

Vice-Decana de Pós-Graduação do Centro de Ciências Sociais - PUC-Rio 
Todos os direitos reservados. É proibida a reprodução total ou parcial do trabalho sem autorização do autor, do orientador e da universidade.

\section{Flavia Guerra Cavalcanti}

Graduou-se em Comunicação Social na Escola de Comunicação (ECO) da Universidade Federal do Rio de Janeiro (UFRJ) em 1997. Trabalhou no Jornal O GLOBO. Mestre em Ciência Política pela UFRJ em 2005. Pesquisa Integração européia e latinoamericana.

Ficha Catalográfica

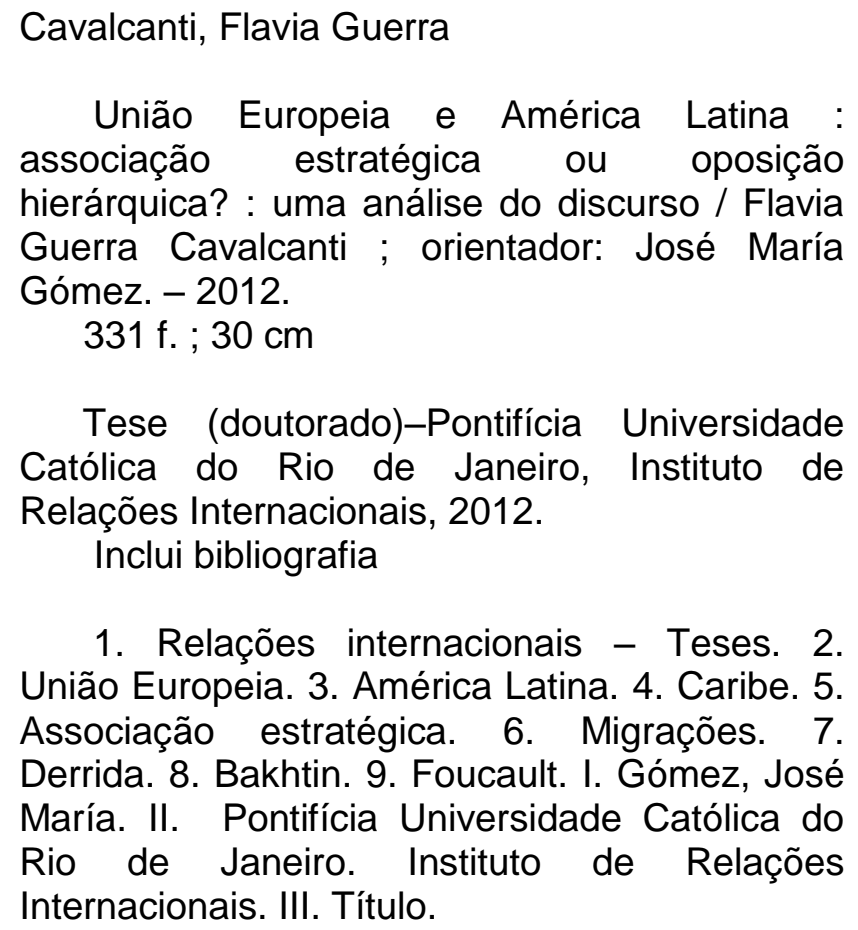

1. Relações internacionais - Teses. 2. União Europeia. 3. América Latina. 4. Caribe. 5. Associação estratégica. 6. Migrações. 7. Derrida. 8. Bakhtin. 9. Foucault. I. Gómez, José María. II. Pontifícia Universidade Católica do Rio de Janeiro. Instituto de Relações Internacionais. III. Título. 
Ao meu pai, Frederico Cavalcanti.

À minha avó, Antonietta Knupfer Cavalcanti (in memoriam). 


\section{Agradecimentos}

Ao Professor José María Gomez, pela orientação e apoio em todos os momentos desse processo.

À Coordenação de Aperfeiçoamento de Pessoal de Nível Superior (CAPES) e à Coordenação Geral de Pós-Graduação da PUC-Rio, pelos auxílios concedidos, sem os quais este trabalho não poderia ter sido realizado.

Aos Professores do Instituto de Relações Internacionais, Nizar Messari, Luís Manuel Rabello Fernandes, Sônia de Camargo, Paulo Esteves e João Pontes Nogueira, pela formação durante o doutorado.

À amiga Érica Simone Resende, sempre presente e disposta a conversar sobre questões acadêmicas.

Ao antropólogo Jean-François Véran, pelas conversas que me levaram à primeira concepção do projeto.

Aos amigos e colegas que me acompanharam nas diversas etapas do doutorado: Tatiana Teixeira, Leonardo Valente, Hugo e Glaura Arend, Danilo Marcondes, Maria Ribeiro, Marta Moreno, Maíra Siman, Ana Garcia, Bárbara Lima, Sabrina Villenave e Charles Pessanha.

À secretária do Instituto de Relações Internacionais Lia Gonzalez, pelas informações e apoio na fase final do processo. 


\section{Resumo}

Cavalcanti, Flavia Guerra; Gómez, José Maria. União Europeia e América Latina: associação estratégica ou oposição hierárquica?. Uma análise do discurso. Rio de Janeiro, 2012, 331p. Tese de Doutorado Departamento de Relações Internacionais, Pontifícia Universidade Católica do Rio de Janeiro.

A associação estratégica entre a União Europeia e a América Latina e o Caribe é apresentada nas declarações de cúpula como um espaço de prosperidade, desenvolvimento e segurança. As duas regiões compartilhariam valores em comum e, por isso, poderiam formar uma "comunidade imaginária". Uma análise dos discursos oficiais mostra, no entanto, que existe uma fratura nesta comunidade devido à presença da diferença colonial. A América Latina e o Caribe ainda são o "Outro" bárbaro, atrasado, em desenvolvimento, que deveria portanto seguir o caminho indicado pelos europeus. A cisão torna-se mais explícita no tema migratório, que coloca as duas regiões em lados opostos. O migrante latinoamericano não é considerado um semelhante do europeu, mas é representado como um "Outro" que deve ser submetido a controles fronteiriços. Por outro lado, a posição do migrante na fronteira lhe confere também um lócus de enunciação e produção do conhecimento a partir da fronteira. Esta tese recorre a autores pósestruturalistas e pós-colonialistas para discutir a possibilidade de contestar, a partir da fronteira, o caráter eurocêntrico do projeto de associação estratégica.

\section{Palavras-chave}

Associação estratégica; União Europeia; América Latina; Caribe; migrante latino-americano. 


\section{Abstract}

Cavalcanti, Flavia Guerra; Gómez, José Maria (Advisor). European Union and Latin America-Caribbean: strategic association or hierarchical opposition? A discourse analysis. Rio de Janeiro, 2012, 331p. PhD Thesis - Departamento de Relações Internacionais, Pontifícia Universidade Católica do Rio de Janeiro.

The summit declarations between European Union and Latin America/Caribbean present their strategic association as a space of prosperity, development and security. Both regions would supposedly share the same values and, as a consequence, participate in an "imaginary community". However, the discourse analysis reveals a community fractured by the colonial difference. Latin America and Caribbean are the barbarous "Other", the one which is "not yet" modern and developed. For that reason, it should follow the european model. The fracture in the strategic association is more explicit in migration issues. Far from being considered an equal, the latin-american immigrant is represented as an "other" which is submitted to border controls. However, the position of the migrant in the border is also an opportunity for producing knowledge from the border. This thesis employs post-structuralism as well as post-colonialism in order to discuss the eurocentric character of the strategic association.

\section{Keywords}

Strategic association; European Union; Latin America; Caribbean; latinamerican immigrant. 


\section{Sumário}

1.Introdução

2. A associação estratégica entre União Europeia e América Latina e Caribe

2.1 Como as abordagens tradicionais tratam o conceito de associação estratégica

2.2 O diagnóstico tradicional 22

2.3. Os "Outros" da Europa 28

2.3.1. Os Estados Unidos são o 'outro', a América Latina é 'irmã': a construção da associação estratégica

2.3. 2. O não dito da associação estratégica: a América Latina ainda é o "Outro" da Europa

2.3.3. A Europa só se constitui como tal a partir da "descoberta" da América

2.3.4. A sensação de "não estar de todo" e a antropofagia

2.3.5. Europa, Estados Unidos e América Latina-Caribe: aproximações e afastamentos

2.3.6. A China como o "outro oriental"

2.4. A Crise Europeia e o fim do modelo

3. Desconstruindo e Descolonizando

3.1. O marco teórico pós-estruturalista e pós-fundacionalista

3.2. Uma concepção de história pós-fundacionalista e pós

Colonialista

3.3 História eurocêntrica e desenvolvimento

3.4. Différance, formação discursiva e genealogia

3.5. Bakhtin: uma abordagem dialógica sobre a história

3.6. É possível compatibilizar o pós-estruturalismo com o póscolonialismo? Différance e Diferonça 
4. O Posicionamento da União Europeia e da América Latina no século XXI: as declarações de cúpula

4.1 A Declaração como gênero de discurso 138

4.2 Polifonia e Intertextualidade $\quad 147$

4.3 Uma genealogia das oposições hierárquicas 156

4.3.1 O cristão e o não-cristão 157

4.3.2 Bárbaro, Selvagem, Canibal 162

4.3.3 Civilização e Barbárie $\quad 167$

4.3.4 Razão e Emoção 173

5. As migrações na associação estratégica 186

5.1 As migrações nas declarações de cúpula 189

5.2 O Western Bond e a migração latino-americana 196

5.3 O Fluxo Migratório entre Europa e América Latina-Caribe $\quad 201$

5.3.1 Os padrões migratórios e as inversões de fluxo 203

5.4. A Diretiva do Retorno e a associação estratégica 208

5.5 Desconstruindo a oposição hierárquica migrante legal/migrante ilegal latino-americano: a hospitalidade incondicional 215

5.5.1 O estrangeiro, o bárbaro e o fantasma 216

5.5.2 O migrante latino-americano na UE: estrangeiro ou bárbaro? 218 5.6 O migrante ilegal latino-americano e o canibal: a dimensão contestadora

6. Conclusão 235

7. Referências Bibliográficas

8. Anexos 


\section{Lista de Tabelas}

Tabela 1 - População Estrangeira latino-americana e Caribenha em países europeus selecionados 


\section{Introdução}

As relações entre a União Europeia e a América Latina e o Caribe constituem um tema clássico da literatura sobre relações internacionais. Não são apenas os discursos oficiais de chefes de Estado e de Governo que consideram as duas regiões como historicamente ligadas. Os textos acadêmicos não raro também fazem esta leitura. Nas abordagens tradicionais, a Europa e a América Latina e o Caribe são tomadas como regiões que existiriam a priori, como entidades previamente constituídas e que, num determinado momento, iniciado com o período das “descobertas", se encontram.

A partir de uma perspectiva pós-estruturalista que considera o discurso como parte da realidade e elemento fundamental de sua constituição, argumentamos que essas entidades Europa (ou União Europeia) e América Latina e Caribe só existem como produto da relação que se inicia no século XVI. Até então, não se pode falar de Europa tal como a conhecemos hoje. Tampouco se poderia falar de uma América Latina e Caribe, distintos da América do Norte e possuidores de um latinismo intrínseco. No marco teórico da desconstrução, poderíamos afirmar que Europa e América Latina/Caribe são um efeito de diferenças e não formas absolutas de ser. Não existe o intrinsecamente europeu nem o especificamente latinoamericano. Ao mesmo tempo, afirmar que a Europa e a América Latina e o Caribe são um efeito de diferenças significa mostrar que elas se constituem mutuamente.

A associação estratégica e os discursos das cúpulas entre a União Europeia e a América Latina e o Caribe representam no século XXI uma nova forma de essas duas regiões continuarem o processo de co-constituição num mundo globalizado. É certo que o termo "associação estratégica" tornou-se recorrente na diplomacia do século XXI entre países e regiões do globo e, por isso, não é uma exclusividade da relação entre a União Europeia e a América Latina. A própria União Europeia pode ter associações estratégicas com vários países e regiões, assim como a América Latina e o Caribe. O que difere a associação estratégica da União Europeia e da América Latina das demais é o tratamento que ela recebe nos discursos oficiais. Nas reuniões de cúpula, iniciadas em 1999 no Rio de Janeiro, a 
associação estratégica é descrita como um momento especial dessas relações, que teria a capacidade de inaugurar uma nova fase de aproximação e, quem sabe, moldar uma nova ordem internacional mais justa e benevolente do que a criada após o fim da Guerra Fria.

Portanto, o que nos interessa discutir não é a associação estratégica em si, cujos resultados práticos são até agora irrisórios, mas o discurso sobre a excepcionalidade dessa relação de associação estratégica entre a União Europeia e a América Latina e o Caribe. O que está envolvido quando se afirma nos discursos das Cúpulas que a União Europeia e a América Latina e o Caribe formam um "nós" que estaria comprometido com determinados objetivos e valores?

Numa primeira leitura, os discursos das cúpulas reproduzem a linguagem diplomática e consensual de outros documentos. Nesse sentido, não haveria nada de muito revelador nesses textos. No entanto, a análise do discurso mostra que não existe "texto menor". Muitas vezes, o texto mais insignificante e secundário de um autor é reinterpretado e passa a ocupar espaço privilegiado no conjunto de sua obra. Uma outra vantagem do "texto menor" seria a possibilidade de ele apresentar questões que não foram suficientemente exploradas nas chamadas obras principais, mas que poderiam trazer novas chaves de leitura para estas. O próprio Derrida escolhe uma obra menor de Rousseau, o Ensaio sobre a Origem das Línguas, para tratar da relação entre a fala e a escrita.

Por esta razão, não pretendemos apresentar os seis documentos das declarações de cúpula como o "texto" fundamental para entender as relações entre a União Europeia e a América Latina e o Caribe. É apenas a partir da intertextualidade entre estas declarações de cúpula e outros textos sobre a Europa, a América Latina, a União Europeia, os Estados Unidos, a antropofagia, o cristianismo, a civilização, a barbárie e o progresso que podemos refletir sobre nosso objeto. Em suma, precisamos recuperar e mobilizar todo um repertório de oposições hierárquicas de outras épocas e contextos para entender o que está em jogo no discurso sobre uma associação estratégica entre as duas regiões. Ou ainda, para percebermos o que permanece silenciado no discurso da associação estratégica.

Um dos objetivos desta tese é apontar, com base na estratégia desconstrutiva de Derrida, como o discurso sobre a associação estratégica mina as próprias oposições hierárquicas que o sustentam. A ideia de um espaço birregional entre UE e América Latina e Caribe é construído com base numa suposta semelhança de 
valores entre as duas regiões. Esta proximidade permitiria impulsionar um projeto de remodelamento da ordem internacional com características diferentes do projeto norte-americano. A criação do "nós" da associação estratégica dependia portanto de uma oposição desse "nós" ao Outro americano. No entanto, a oposição hierárquica nós/outro norte-americano é enfraquecida por discursos que representam o latino-americano como um "outro bárbaro".

Estas relações com o "outro norte-americano" ou com o "outro bárbaro latino-americano" não estão explícitas nas declarações de cúpula. Só chegamos a estes "outros" pela análise das cadeias de significantes que, em variados contextos, produz efeitos de diferenciação. Assim, o outro norte-americano é intuído quando analisamos o contraste entre as declarações de cúpula e os discursos de George W. Bush sobre o combate ao terrorismo. O outro norte-americano também surge claramente nos discursos de Habermas e Derrida contra a Segunda Guerra do Iraque.

O "outro bárbaro latino-americano" apresenta-se em diferentes momentos na relação da Europa com a América Latina, às vezes sob os termos canibal, antropófago, não-cristão, não civilizado. Apesar de a associação estratégica entre União Europeia e América Latina e Caribe ser uma tentativa de criar uma "comunidade imaginária", como prevista por Benedict Anderson, o discurso sobre o outro bárbaro latino-americano retorna e coloca em risco esse projeto. Porém, esse retorno não se dará na mesma linguagem dos séculos XVI a XIX, repleta de termos como canibal, antropófago, bárbaro, não civilizado. O outro bárbaro latinoamericano retorna sob a forma do migrante ilegal latino-americano, o qual, no entanto, guarda a marca daqueles outros termos. Em outras palavras, o migrante ilegal latino-americano carrega rastros do bárbaro, do canibal, do antropófago... Entre estes traços, está a dimensão contestadora da divisão entre eu e outro. O canibal e o Calibán de Shakespeare são quase revolucionários. Há também uma crítica potencial a uma narrativa hegemônica sobre o surgimento da Europa e a "descoberta" da América, que se transformaria gradativamente, nos séculos seguintes, numa cópia da Europa.

É importante lembrar que esta suposição sobre o caráter contestatório do migrante ilegal latino-americano não é algo intencional. É a sua presença que, por si só e inadvertidamente, apresenta a crítica ao status quo da Fortaleza Europa anti-imigrantes. De acordo com o marco teórico e os autores aos quais recorremos 
na tese, não podemos partir do pressuposto de um sujeito autônomo, moderno e centrado que colocaria uma crítica à narrativa europeia da associação estratégica. Quando nos referimos à dimensão crítica do migrante latino-americano, não estamos querendo significar uma intencionalidade do migrante latino-americano. Não há completa autonomia na utilização do discurso, como veremos com Bakhtin. Somos limitados pelo gênero do discurso (Bakhtin) ou por formações discursivas (Foucault, Laclau e Mouffe), e é dentro desta moldura conceitual que falamos. Portanto, a crítica "apresentada" (os verbos podem nos levar a interpretações equivocadas sobre a existência de um sujeito autônomo) pelo migrante é, na verdade, uma crítica que resulta de práticas discursivas. O bárbaro contestava a ordem da pólis; o canibal representava uma provocação à civilização europeia. Esses discursos contra-hegemônicos continuarão sendo "apresentados" pelo migrante ilegal latino-americano.

Em relação à capacidade de agência desse migrante ilegal latinoamericano, nada nos garante que ela seja possível como decorrência de sua posição crítica. As discriminações, racismos e exclusões são revelados pelo discurso contra-hegemônico, mas isto pode não ser suficiente para uma efetiva mudança da forma como a hospitalidade e as fronteiras entre os Estados são hoje pensadas. A exclusão e marginalização são tais que impedem qualquer ação mais efetiva por parte desse migrante.

Para mostrarmos os deslocamentos nas cadeias de significantes, utilizamos uma análise genealógica, que, por definição, está mais interessada no presente do que no passado. Por esta razão, não faremos uma análise sobre cada período histórico; apenas retomaremos discussões de outros períodos quando elas apresentarem rastros no presente.

A relevância da pesquisa reside na possibilidade de pensarmos, no século XXI, uma relação que esteve na base da constituição do mundo moderno. A formação da Europa e da América Latina ocorreu de forma concomitante e teve influência na conformação do mundo moderno. Quais as possibilidades de a relação atual - a da associação estratégica - remodelar as identidades da União Europeia e da América Latina? E ainda: qual a chance de esta relação ter algum impacto no sistema internacional contemporâneo? Consideramos que a relação entre estas duas entidades que surgiram nos primórdios do mundo moderno ainda é fundamental para entendermos as transformações e desafios da política contemporânea. 
A ideia de uma associação estratégica birregional é apresentada como um espaço de segurança, progresso e generosidade, em contraste com o mundo exterior anárquico e ameaçador. As ilusões sobre a criação de um inside resguardado de todos os infortúnios contra um outside permanecem, portanto, como um discurso estruturador do internacional. Este projeto revela ainda uma tentativa de resgate da "Ideia de Europa" como modelo civilizacional e um convite à América Latina e Caribe para participarem da empreitada. É importante notar que a noção de "civilização europeia”, cuja formação começou no século XVI no contato com a América - "sem nós, não haveria Europa" -, continua a se reportar à América Latina para continuar seu trabalho. O despertar da Europa, como previu Sloterdijk (capítulo 2), se manifesta numa associação estratégica com a América Latina.

No capítulo 2, exploramos o conceito de associação estratégica e apresentamos algumas leituras sobre o porquê do fracasso desse projeto entre União Europeia e América Latina. Nesta abordagem das teses tradicionais, mostramos suas limitações e antecipamos o marco teórico que empregaremos ao longo da tese para tratar da relação UE-América Latina. Também discutimos neste capítulo os "outros" da Europa, "outros" importantes na sua constituição, "outros" que permanecem e estruturam a identidade da União Europeia e da América Latina e Caribe e, ainda, "outros" mais recentes como a China. Se o triângulo Europa-América Latina-Estados Unidos sempre foi um tema clássico - e incontornável - quando se pensava em estudar a América Latina ou a Europa, talvez no futuro tenhamos de considerar um "outro chinês" que já surge nos discursos da Europa, dos Estados Unidos e da América Latina. Mas este seria um tema para outra oportunidade. Apenas nos limitamos em pontuar o surgimento desse "outro oriental".

É a partir da tentativa de a Europa se diferenciar dos Estados Unidos e retomar seu projeto civilizatório que a associação estratégica com a América Latina deve ser entendida.

No capítulo 3, apresentamos nosso marco teórico pós-estruturalista e tentamos mostrar as aproximações e possíveis conexões entre Michel Foucault, Laclau, Mouffe, Bakhtin e Derrida. No entanto, completamos nossa reflexão teórica com autores pós-colonialistas como Aníbal Quijano, Walter Mignolo, Enrique Dussel, Arturo Escobar e Fernando Coronil. O objetivo é aproximar a desconstrução e a descolonização, mostrando as semelhanças entre ambas e a possibilidade de combiná-las na análise da relação entre a União Europeia e a América Latina e 
o Caribe. Um de nossas discussões teóricas diz respeito à possibilidade de unir desconstrução e descolonização a partir do conceito de antropofagia.

No capítulo 4, examinamos o discurso das declarações de cúpula em seus aspectos gerais, sem nos determos num assunto específico. Em seguida, empreendemos uma análise genealógica das oposições hierárquicas que perpassam a relação entre as duas regiões em diversas épocas e contextos históricos. Percebemos assim a "variação na repetição" ou a "dispersão na regularidade" nos discursos entre as duas regiões.

No quinto e último capítulo, analisamos a questão da migração na associação estratégica. As oposições hierárquicas discutidas no capítulo 4 são aqui pensadas em torno do migrante latino-americano. Nesta parte, o conflito e a cisão da associação estratégica se tornam mais visíveis. Quando se trata de migrantes ilegais latino-americanos, sem raízes europeias ou com um espanhol não padrão, o discurso acolhedor da associação estratégica revela seu caráter puramente instrumental. A nossa análise é aqui realizada a partir do ponto de vista do migrante ilegal latino-americano, como ele é afetado pelas oposições hierárquicas que persistem na relação entre União Europeia e América Latina-Caribe. Também indagamos sobre seu potencial de contestação do discurso oficial das cúpulas e sua capacidade simbólica de representar o ponto de vista da América Latina sobre a associação estratégica. 


\section{A associação estratégica entre União Europeia e América Latina-Caribe}

As reuniões de cúpula entre a União Europeia e a América Latina e o Caribe iniciaram-se em 1999 com a proposta era criar uma "associação estratégica" entre as duas regiões. Pode-se objetar que a União Europeia assina acordos com diversas regiões, inclusive com aquelas que podem ser consideradas como "Outros" contemporâneos da Europa, como os Estados Unidos ou os países do Mediterrâneo. Desta forma, a associação estratégica entre a União Europeia e a América Latina não seria diferente de qualquer outro acordo e, consequentemente, não haveria motivos para que a considerássemos especial.

De fato, o documento European Security Strategy (ESS), de 2003, propõe parcerias estratégicas da Europa com vários atores centrais. Embora seis países sejam mencionados - EUA, Rússia, Japão, China, Canadá e Índia -, a lista de parceiros estratégicos não está fechada. Ao contrário, uma parceria estratégica poderia ser desenvolvida com "todos aqueles que compartilham nossos objetivos e valores e estão preparados para agir em sua defesa" (ESS, 2003, p. 1). Portanto, não há uma lista oficial de parceiros estratégicos da União Europeia. A lista depende do significado que se atribui ao termo parceria, como veremos na próxima seção. Em fevereiro de 2010, por exemplo, o presidente do Conselho Europeu, Herman Van Rompuy, incluiu o Brasil como parceiro estratégico. Em julho do mesmo ano, a comissária de Comércio Europeu, Catherine Ashton, apresentou uma outra lista, composta por EUA, Rússia, Japão, Canadá, China, Índia, Brasil, África do Sul e Indonésia.

Por outro lado, a União Europeia mantém parcerias que não recebem a denominação de estratégicas, como, por exemplo, a "União para o Mediterrâneo "1", formada em 1995 a partir da Declaração de Barcelona. Esta parceria não se assemelha a uma "associação estratégica", uma vez que visa tão-somente a tratar de problemas regionais, como energia, segurança, terrorismo, imigração, comércio e

\footnotetext{
${ }^{1}$ A União para o Mediterrâneo reúne os 27 da União Europeia, cinco países do norte da África (Argélia, Egito, Marrocos, Mauritânia e Tunísia), quatro países do Oriente Médio (Israel, Jordânia, Líbano, Síria), Autoridade Nacional palestina, Turquia, Albânia, Croácia, Bósnia Herzegovina, Montenegro e Mônaco.
} 
meio-ambiente. O Mediterrâneo não é visto como um parceiro estratégico que possa fortalecer a influência europeia no sistema internacional, mas como uma região cuja eventual instabilidade ameaça a segurança europeia. Desta forma, o Mediterrâneo é tratado mais como um problema (a chegada à Europa de refugiados do Egito, da Tunísia e da Líbia causa apreensão nos governos do continente) do que como uma contribuição ao projeto europeu de reafirmação internacional.

Assim, podemos perceber que a relação entre União Europeia e América Latina difere tanto das parcerias estratégicas previstas no European Security Strategy (ESS) quanto do processo de Barcelona. Os seis países citados no ESS como estratégicos não precisam compartilhar valores comuns com a Europa, tanto que China, Índia e Japão estão incluídos no documento. A motivação para a parceria estratégica prevista no ESS é outra: o poder econômico e político daqueles países.

O inverso ocorre no processo de Barcelona. Os países mediterrâneos do Norte da África apresentariam uma história e uma cultura relativamente semelhante à dos europeus. Segundo a Declaração conjunta da Cúpula de Paris para o Mediterrâneo, “a Europa e os países do Mediterrâneo estão unidos pela história, geografia e cultura" (2008, p. 9). No entanto, eles não são elevados ao status de parceiros estratégicos.

A relação da América Latina e do Caribe com a União Europeia é a única a combinar valores comuns como motivação para a parceria e associação estratégica. A excepcionalidade desta relação fica evidente quando adotamos um marco teórico pós-estruturalista. O discurso sobre a excepcionalidade da relação UEALC é tão revelador quanto a simples ocorrência da relação em si. "Quando um autor comete um engano ou mente, seu texto não é menos significativo do que quando diz a verdade" (Todorov, 1982, p. 75).

Portanto, a pergunta recorrente em debates e textos sobre se uma "associação estratégica" entre a União Europeia e a América Latina/Caribe existe de fato está mal colocada. A pergunta que deveríamos nos fazer, a partir de uma perspectiva pós-estruturalista, é “o que a União Europeia quer significar ao dizer que tem uma associação estratégica com a América Latina/Caribe?" ou ainda "Por que, apesar de também ter laços culturais com a África, decorrentes do processo de colonização, a União Europeia não opta por uma parceria estratégica com a África com base no argumento dos valores comuns?" 
A associação estratégica entre a União Europeia e a América Latina/Caribe torna-se relevante para o estudo das relações internacionais contemporâneas na medida em que ela se apresenta como um dos projetos de resistência à hegemonia americana. Nesse sentido, Juan Pablo de Laiglesia, Secretário de Estado para Iberoamérica do Ministério de Assuntos Exteriores e de Cooperação da Espanha, referiu-se à UE e à ALC como um "Novo Ocidente" capaz de apresentar uma "visão sobre a nova governança da globalização" (Laiglesia, 2010, p. 1).

Mas o discurso sobre a possibilidade de um novo Ocidente só faz sentido se as duas regiões forem apresentadas como naturalmente semelhantes, detentoras de valores comuns. Esta argumentação, por sua vez, só se sustenta se partirmos do pressuposto de que tais valores em comum estão relacionados à latinidade. Por outro lado, como veremos ao longo desta tese, os “valores latinos" são a expressão de um discurso monológico sobre a formação cultural da América Latina e do Caribe que deixa em segundo plano as vozes indígenas e africanas.

Nossa hipótese é de que a "comunidade imaginada" (Anderson, 2008) que as declarações de cúpula tentam criar entre a União Europeia e a América Latina e o Caribe é perpassada pelas tensões e ambiguidades presentes tanto no discurso europeu sobre a América Latina-Caribe quanto no discurso latino-americanocaribenho sobre a Europa. A comunidade imaginada é cindida pela visão europeia do latino como bárbaro, assim como pela "sensação de não estar de todo" (Süssekind, 1990) presente no discurso latino-americano.

Essas tensões estão atenuadas nas declarações das cúpulas porque o pronome "nós", exaustivamente repetido nestes documentos oficiais, produz um efeito monológico, consensual. Contudo, as ambiguidades se tornam mais visíveis quando analisamos o contexto, atual e passado, das relações entre a União Europeia e a América Latina e o Caribe. A análise do discurso genealógica mostrará o caráter conflituoso e político dessa relação.

\section{1}

\section{Como as abordagens tradicionais tratam o conceito de associação estratégica}

O conceito de associação estratégica é impreciso e até o momento não há, por parte da União Europeia, uma tentativa de definir seu conteúdo. "Apesar de 
seu uso exaustivo e de sua significação, o termo associação estratégica permanece como um dos mais indefinidos instrumentos da política externa da União Europeia" (Liszczyk, 2010, p. 1). Para Giovanni Grevi, a falta de clareza conceitual, ainda que não intencional, seria uma vantagem por permitir o grau de flexibilidade e ambiguidade necessário para ajustes e concessões de ambos os lados. Tomando emprestado um conceito de Jacques Derrida, estaríamos lidando com um indecidível (ver capítulo teórico). A associação estratégica tanto pode significar uma relação privilegiada quanto uma relação supérflua e efêmera.

As poucas e vagas definições presentes nos documentos da União Europeia tratam a associação estratégica como um meio para atingir determinados fins. No relatório da Comissão Europeia denominado "Uma parceria mais forte entre a União Europeia e a América Latina", a associação estratégica birregional é estabelecida para "forjar relações fortes nas esferas política, econômica e cultural" (Comissão Europeia, 2005, p.6). Thomas Renard também destaca o caráter instrumental da parceria estratégica ao apresentá-la como "uma moldura para elevar o diálogo entre as partes ao nível das Cúpulas" (2010, p.3). Na visão de Thomas Cieslik, as nações tentam aumentar seu poder e esfera de influência na política internacional por meio do instrumento clássico da parceria estratégica. No caso da União Europeia, a associação estratégica serviria para promover uma ordem mundial alternativa, contrária à dos Estados Unidos e baseada na democracia, no Estado de Direito, nos direitos humanos e na coesão social.

Estas interpretações partem do pressuposto de que existiriam duas entidades pré-constituídas, pré-estabelecidas - a União Europeia e a América Latina e o Caribe - que lançariam mão do instrumento da associação estratégica para se posicionarem no sistema internacional. A partir de um marco teórico pósestruturalista, que será desenvolvido no capítulo 3, é possível problematizar esta abordagem. Em vez de "instrumento" de duas "entidades" previamente existentes, a associação estratégica pode ser vista antes como uma prática discursiva que constroi identidades, neste caso a das regiões "União Europeia" e "América Latina e Caribe". Em outras palavras, não são as entidades (União Europeia/América Latina/Caribe) que constroem a relação da "associação estratégica", mas, ao contrário, é a relação de associação estratégica que produz discursivamente uma representação da União Europeia e da América Latina e do Caribe assim como uma representação de um espaço birregional. Sendo um indecidível, a associação estra- 
tégica ora significa "relação privilegiada", criando assim identidades semelhantes para Europa e América Latina-Caribe, ora "relação supérflua", em que a identidade latino-americana seria o oposto da da Europa.

Como argumentou Jacques Derrida ao se referir à Declaração de Independência Americana, "O povo não existe. Ele não existe como uma entidade, ele não existe antes da declaração" (Derrida, 1986, p.10). O ato da fundação é, em si mesmo, um golpe de força performativo que cria uma autoridade sem outro fundamento senão aquele criado pelo próprio golpe de força. De acordo com este raciocínio, a primeira declaração das cúpulas, de 1999, teria, portanto, representado o ato fundador da associação estratégica e do espaço birregional como "comunidade imaginada".

É justamente por ser uma prática discursiva que cria uma comunidade apenas imaginada que a associação estratégica precisará ser constantemente reproduzida nos textos oficiais das cúpulas seguintes $(2002,2004,2006,2008,2010)$. Sendo a comunidade "sem fundamento", ela só poderá continuar existindo enquanto o coup de force do ato fundador (as declarações) puder ser repetido discursivamente, recriando a cada momento as identidades da União Europeia e da América Latina e Caribe.

Revela-se aqui o caráter não-fundacionalista da associação estratégica. Como veremos com mais detalhes no capítulo teórico, o pensamento pósfundacionalista não se baseia numa ausência de fundamento, mas na impossibilidade de um fundamento último. O fundamento é contingente e não definitivo. Daí a necessidade de uma constante repetição do ato fundacional. Derrida refere-se à iterabilidade (1991, p. 19) como a capacidade de a escrita ser repetida, mas esta repetição não é um retorno do mesmo. A iterabilidade significa repetição, diferença, alteração e singularidade. Na lógica da iterabilidade, temos repetição mecânica e, ao mesmo tempo, transformação e singularidade. Ou seja, a repetição produz a diferença. A repetição e a cópia sempre criam algo novo, diferente do original uma nova singularidade.

Como veremos à frente, o discurso da associação estratégica é, também ele, uma repetição de estratégias discursivas presentes em outros momentos históricos, ainda que esta repetição seja perpassada pela transformação e pela singularidade. Desta forma, podemos dizer que a associação estratégica do final do século 
XX e início do XXI representa uma relação singular entre a União Europeia e a América Latina.

Um dos objetivos da "associação estratégica" apontados pelas abordagens tradicionais é o de redefinir a política externa da União Europeia, contrastando-a com a dos Estados Unidos em termos de valores como democracia, estado de direito e direitos humanos. A União Europeia teria interesse em construir uma nova ordem mais benevolente e justa do que aquela concebida pelos Estados Unidos após o fim da Guerra Fria e o 11 de setembro. A “associação estratégica" é apresentada como um instrumento que permitiria à União Europeia afirmar a "sua identidade" em contraste com a dos Estados Unidos (ver seção 4.1 deste capítulo), como se UE e EUA fossem duas entidades pré-constituídas.

No entanto, a associação estratégica é produto de um processo de iterabilidade e se constitui como uma prática discursiva que cria as identidades "União Europeia" e "América Latina-Caribe". Ela não é um mero instrumento ao qual recorrem entidades já dadas.

Nesse processo de iterabilidade, a identidade da América Latina e do Caribe é construída como semelhante à da União Europeia em termos de valores como democracia, direitos humanos, respeito à lei internacional. Já os Estados Unidos aparecem discursivamente representados como o "outro" que preza o unilateralis-

mo na política internacional. É, portanto, a partir da diferenciação em relação a esse outro americano que a União Europeia e a América Latina e o Caribe podem constituir suas identidades como regiões benévolas, defensoras dos direitos humanos e da lei internacional.

\section{2}

\section{O diagnóstico tradicional}

As reuniões de cúpula entre a União Europeia e a América Latina e o Caribe, iniciadas em 1999 no Rio de Janeiro, não têm gerado os resultados esperados por ambas as partes. As frustrações das duas regiões podem ser notadas a partir da análise das declarações não-oficiais, com contínuas censuras mútuas. Em decorrência desta situação de desconforto, os especialistas nas relações União Europeia e América Latina-Caribe tentam desvendar as causas do impasse, ora apontando a negligência da União Europeia ora lembrando o despreparo da América Latina e 
do Caribe. Assim, a proclamada lentidão do processo de cúpulas é atribuída a diversos fatores, como o descrédito do regionalismo, o 11 de setembro, o terrorismo, o alargamento da União Europeia, o Tratado de Lisboa, o populismo latinoamericano, a ascensão econômica da Ásia, a preocupação excessiva com interesses nacionais de ambos os lados, a precariedade das instituições e os problemas na integração sul-americana.

Para José Antonio Sanahuja, o projeto político de uma associação birregional teria sido prejudicado pela exaustão do modelo de "regionalismo aberto" dos anos 90, cujos instrumentos principais foram os acordos de livre-comércio entre as duas regiões. O conceito de "regionalismo aberto" expressava a ideia de um regionalismo não exclusivo, ou seja, não haveria desvio de comércio, prejudicando terceiros. Ao contrário, o regionalismo aberto seria compatível com a abertura comercial. A expressão "regionalismo aberto" é um oxímoro, já que o primeiro termo pressupõe um fechamento na região, enquanto o segundo aponta para a abertura. O descrédito do regionalismo aberto cede lugar a uma concepção de regionalismo baseada na integração física e energética entre Estados contíguos. Nesse contexto, a ideia de associação birregional perde força por não satisfazer o critério da contiguidade.

O autor destaca ainda o impacto dos atentados de 11 de setembro e da guerra no Afeganistão nas relações birregionais entre a União Europeia e a América Latina e o Caribe. Aqueles dois eventos teriam contribuído para aumentar a preocupação da Europa com a segurança e o terrorismo, relegando o desenvolvimento e a democracia na América Latina e no Caribe a uma posição secundária em sua lista de prioridades. Em outras palavras, teria ocorrido um afastamento entre as duas regiões a partir de 2001. "A maioria dos Estados-membros está reduzindo a ajuda bilateral para a América Latina (...) para direcioná-la para países prioritários na 'guerra contra o terrorismo"” (Sanahuja, Freres, 2006, p. 37). No entanto, em outra seção do texto, os mesmos autores irão afirmar a proximidade entre a União Europeia e a América Latina no que diz respeito ao multilateralismo como meio de lidar com o terrorismo. Há a necessidade de "reagir aos atentados de 11 de setembro de 2001 e às guerras do Afeganistão e do Iraque, o que é percebido como uma política unilateral e hegemônica por parte dos Estados Unidos" (Ibidem, p. 42). 
Entendemos que este tipo de abordagem não é suficiente para explicar a indecidibilidade da associação estratégica entre União Europeia e América Latina e Caribe. A associação estratégica pode significar a aproximação das duas regiões (quando estas são representadas como semelhantes) ou, ao contrário, o afastamento de ambas (quando o latino-americano é visto como bárbaro).

Nas narrativas tradicionais, a aproximação e o afastamento são provocados por um evento específico, como, por exemplo, um ataque terrorista. Sustentamos que este acontecimento só adquire significado quando compreendido a partir das práticas discursivas que constroem as relações entre a União Europeia e a América Latina e o Caribe. Ou seja, não é o ataque terrorista em si que gera uma aproximação ou um afastamento entre a União Europeia e a América Latina e o Caribe, mas sim o sentido que a ele é dado pelas práticas discursivas. Como nos lembram Ernesto Laclau e Chantal Mouffe, os objetos não podem "se constituir enquanto tais fora de qualquer condição discursiva" (1985, p. 108).

Considerando que o discurso europeu sobre a América Latina é ambíguo, tratando a região ora como semelhante (a ideia de região-irmã) ora como diferente (o Outro), temos duas interpretações diferentes para o impacto do terrorismo na associação estratégica. Quando a América Latina e o Caribe são considerados como uma extensão do Ocidente e, portanto, semelhantes à Europa, o termo terrorismo é utilizado nos discursos como um inimigo comum contra o qual as duas regiões se uniriam. A União Europeia e a América Latina e o Caribe compartilhariam a mesma abordagem multilateral no combate ao terrorismo, contrapondo-se à percepção norte-americana sobre o tema, particularmente no governo Bush. Ao contrário, quando a Europa trata a América Latina e o Caribe como um Outro, um "suplemento dispensável", a palavra terrorismo é usada para excluir a América Latina e o Caribe da lista de prioridades da União Europeia e justificar o redirecionaciomento dos recursos para "os países com risco terrorista".

Segundo o diagnóstico tradicional, um terceiro motivo para o afastamento entre a União Europeia e a América Latina-Caribe seria a ascensão econômica da Ásia, especialmente da China. Cada uma das regiões (UE ou ALC) teria supostamente mais interesse em realizar negócios com a Ásia do que entre si. Para Günther Maihold, a União Europeia tem de se dar conta de que a emergência da China como parceiro para a América Latina "causou uma mudança profunda na parceria privilegiada" (2007, p. 13). No entanto, o mesmo pode ser dito em rela- 
ção à Europa; esta também estaria interessada numa parceria privilegiada com a China, tanto é que o país consta da lista de "parcerias estratégicas" da União Europeia, como vimos na European Security Strategy. Segundo Klaus Bodemer, “a música econômica para as empresas e para os governos europeus soa na Ásia, mais especificamente na China" (2010, p.113). De acordo com esta interpretação, o afastamento entre a União Europeia e a América Latina teria causas externas e econômicas. Não há qualquer consideração nestas análises sobre a existência - e a importância - de um discurso sobre valores comuns entre União Europeia e América Latina Caribe, assim como sobre a ausência deste mesmo discurso quando se trata da relação entre Europa e China ou entre América Latina e China (ver seção 2.3.6, a China como Outro).

Desta forma, pretendemos apresentar uma abordagem diferente daquela que considera apenas causas externas e econômicas. Nosso pressuposto é de que discursos de aproximação (semelhança) e afastamento (diferença) entre União Europeia e América Latina não podem ser explicados pela lógica da ascensão econômica da China ou em termos de interesses materiais e capacidades divergentes. Como no exemplo já mencionado do terrorismo, não é o acontecimento em si da ascensão da China que nos ajuda a entender a dinâmica de aproximação e afastamento.

Outra análise bastante corrente atribui a causa da lentidão do processo de cúpulas ao alargamento da União Europeia nos anos 2000 e à aprovação do Tratado de Lisboa (Arenal, 2010; Gratius, 2010; Malamud, 2010; Sanahuja, 2008). Para Gratius e Sanahuja, a União Europeia teria incorporado países que têm pouco ou nenhum interesse numa aproximação com a América Latina e o Caribe.

As sucessivas ampliações da União (...) influíram negativamente no interesse do conjunto da União sobre a América Latina, já que nem a maioria dos novos países da Europa central e oriental, nem os do Mediterrâneo (Chipre ou Malta) possui um excessivo interesse no subcontinente latino-americano (Malamud, 2010, p.4).

Além disso, as mudanças introduzidas pelo Tratado de Lisboa na presidência da União Europeia (em vez do rodízio de seis meses, um mandato de 3 anos) diminuiriam a freqüência com que países favoráveis à aproximação com a América Latina, como Portugal e Espanha, ocupariam a presidência da União Europeia. Além disso, a ampliação do número de membros da UE diluiria a influência de 
Portugal e Espanha, contribuindo para um afastamento entre UE e América Latina. Aqui também percebemos uma tentativa de explicar o afastamento por meio de causas materiais e externas: a entrada no bloco de países do Leste e a diluição de poder dos países ibéricos.

Esta análise condiciona a importância da América Latina para a Europa à capacidade de influência das antigas metrópoles coloniais: Portugal e Espanha. Pressupõe-se que havia, no século XVI, duas entidades ou dois sujeitos inteiramente constituídos - Portugal e Espanha - que num determinado momento teriam "descoberto" um mundo novo e vazio, ainda em formação. Como veremos na seção 2.3.3 deste capítulo, América e Europa se constituíram mutuamente. Não havia no século XVI identidades pré-constituídas (Espanha, Portugal ou Europa como entes). É justamente o "encontro" decorrente das grandes navegações e as relações que se estabeleceram a partir de então entre Europa e América que deram origem a estratégias discursivas de criação de identidades.

Em suma, a abordagem tradicional positivista atribui o afastamento UEAmérica Latina ao poder ou falta de poder dos países ibéricos, como se só eles tivessem influenciado ou sido influenciados pela América Latina. A exploração econômica das colônias pelas metrópoles ganha o primeiro plano. Ao contrário, a abordagem pós-positivista e a ênfase em elementos não-materiais nos permite afirmar que toda a Europa - e não apenas Portugal e Espanha - foi constituída pela América assim como a constituiu. Como veremos na seção 4.2.1, a relação UE-América Latina não é condicionada meramente por uma questão conjuntural (a atuação ou não atuação dos ibéricos na UE), mas pela ambiguidade do discurso europeu em relação à América Latina.

O diretor do Observatório das Relações União Europeia e América Latina (Obreal), Ramón Torrent, considera que as dificuldades da associação estratégica se devem "ao excesso de interesses nacionais, que acabam por obscurecer os resultados finais das cúpulas" (2006, p.1). Para Torrent, a União Europeia tem de lidar com os interesses de seus numerosos Estados-membros, enquanto estes prefeririam agir unilateralmente e manter relações bilaterais com os Estados da América Latina e do Caribe. Além da influência excessiva dos interesses nacionais, Torrent aponta o descompasso entre a ambição política das cúpulas e a precariedade das instituições. 
Também não são incomuns as análises que localizam na América Latina/Caribe o ponto nevrálgico do fracasso da associação birregional. Segundo Héctor Casanueva, a agenda da associação estratégica não avança porque a América Latina apresenta problemas em sua integração e, consequentemente, não consegue articular uma proposta para as cúpulas. Casanueva reproduz a visão da União Europeia durante a cúpula de Viena, em 2006, quando o bloco declarou que a associação estratégica não poderia progredir enquanto a América Latina não falasse com uma única voz, ou seja, enquanto não fosse um bloco consolidado com todos os seus problemas internos resolvidos.

Nesse sentido, Malamud afirma que a "América Latina e o Caribe têm tantas vozes quantos são os governos participantes, e cada uma delas se expressa em função de seus próprios interesses" (2010, p. 27). Argumento semelhante é defendido por Félix Peña, para quem os problemas da associação estratégica estão relacionados à dimensão organizacional da integração. Os resultados da associação estratégica foram percebidos como insatisfatórios por causa das "diversidades e assimetrias existentes nas formas de organização de cada uma das regiões" (2010, pág. 16). Nestas avaliações, a União Europeia aparece como o modelo da integração e a América Latina como a região que ainda não encontrou seu rumo:

(...) no espaço europeu existe uma construção institucional relativamente sólida e com um grande potencial de irreversibilidade. (...) De outro lado, na América Latina e no Caribe os esforços de integração regional apresentam ainda riscos de fragmentação e de relativa precariedade (Peña, 2010, p. 16).

Os estudos sobre as relações entre a União Europeia e a América Latina apontam causas materiais externas e institucionais como obstáculo para a associação estratégica. Estas causas derivam de fatores conjunturais localizados na segunda metade do século XX.

Nossa abordagem pretende destacar a existência de práticas discursivas que criam identidades distintas para a Europa e para a América Latina e o Caribe. Não existem sujeitos ou identidades constituídos pré-discursivamente. A identidade só se forma por processos discursivos. Ou seja, nenhum Estado ou região (América Latina ou União Europeia) possui uma identidade estável e prédiscursiva. 
As estratégias discursivas apresentam a América Latina e o Caribe ao mesmo tempo como semelhante (um outro ocidente) e como diferente (um outro bárbaro). A nosso ver, é esta oscilação discursiva que constitui o quadro interpretativo para a análise das relações entre a União Europeia e a América Latina. Entretanto, a oscilação detectada na relação entre a União Europeia e a América Latina não é exclusiva do século XX. A ideia de uma oposição hierárquica já estava presente na época do "Descobrimento" da América. É verdade que a semelhança entre ambas as regiões não se fazia tão presente, a não ser pelos discursos de Francisco de Vitória sobre a unidade da natureza e do gênero humano. Quando o termo "América Latina" é criado no século XIX por intelectuais franceses, a semelhança ganha o primeiro plano, embora a oposição hierárquica continue emergindo nos discursos. Em suma, a ambiguidade no discurso europeu sobre a América Latina remonta ao século XVI.

\section{3}

\section{Os "Outros" da Europa}

Vários "Outros" têm sido fundamentais no processo de formação de uma identidade europeia. A oposição entre infiéis e bárbaros, de um lado, e povos civilizados, de outro, perpassa a história do continente (Harbsmeier, 1985). A velha retórica entre Ocidente (civilizado) e Oriente (bárbaro) "estruturou a autocompreensão dos europeus desde Heródoto e Péricles” (Marquand, 2011, p.9).

Segundo Neumann, a identidade europeia sempre se formou em relação ao “Oriente", sendo que o termo "Oriente" deve ser compreendido como uma metáfora para o outro e não necessariamente uma localização geográfica situada a leste. "Como o outro é uma invenção humana, embora as diferenças culturais entre eu e outro possam ser suficientemente reais, no fundo é historicamente arbitrário quem num determinado momento ocupa o lugar do outro" (Neumann, 1999, p. 41).

No século XXI, abundam os candidatos a outros contemporâneos da Europa, ainda que cada um deles apresente características específicas. Talvez possamos distinguir entre tipos de "outros". Entre os "outros" situados nas bordas da Europa, podemos mencionar o Norte da África, o Oriente Médio, a Rússia e a Turquia. 
O Norte da África e o Oriente Médio se destacariam como "outros radicais". Desses espaços proviria hoje a maior parte dos imigrantes indesejados da União Europeia. Já a Rússia continua desempenhando o papel de outro que historicamente lhe foi atribuído pela Europa, ora bárbara ora civilizada. Teríamos aqui um "outro tradicional".

Na visão de Neumann, a Turquia seria o "Outro" dominante na história do sistema estatal europeu. Os turcos foram representados a partir do século XV como "sinônimo de crueldade, despotismo e depravação. (...) Uma acusação típica aos turcos era que eles teriam propensão para o estupro homossexual" (Marquand, 2011, p. 3). Recentemente, a candidatura da Turquia à União Europeia tem gerado debates sobre se a identidade europeia, historicamente associada ao cristianismo, não sofreria um abalo com a entrada de um país majoritariamente muçulmano no bloco.

A primeira abordagem sobre os outros da Europa estaria, portanto, relacionada àqueles que estão mais próximos geograficamente e contra os quais a Europa precisa afirmar sua identidade. No entanto, a União Europeia também vem se posicionando nas duas últimas décadas contra "Outros" situados em regiões mais distantes. Assim, o norte-americano, o latino-americano ou o chinês/asiático surgem nos discursos contemporâneos como "outros" que se destacariam por características diferentes das europeias.

\subsection{1}

\section{Os Estados Unidos são o 'outro', a América Latina é 'irmã': a cons- trução da associação estratégica}

Ao contrário dos turcos, os índios americanos do "Novo Mundo" eram representados pelos europeus como ingênuos, destituídos de luzes, porém capazes de aprender a religião cristã. Por mais que o americano constituísse um outro para a Europa, esse outro não adquiria o caráter de uma ameaça ou invasão iminente ao seu território, como no caso dos turcos.

A relação entre Europa e América poderia assim ser melhor definida pela expressão "inimigos íntimos". Nos primeiros séculos da "descoberta" do "Novo Mundo", a América do Norte e a América do Sul eram tratadas de forma indistinta 
e seus habitantes eram genericamente referidos como índios. Todos os americanos, portanto, eram bárbaros que precisavam ser convertidos e civilizados pelos conquistadores europeus, sem distinção entre norte e sul. Neste sentido, a experiência do "Novo Mundo" serviu como um recurso de diferenciação para a Europa e, consequentemente, para a criação de uma identidade europeia.

No entanto, as diferenças entre o Norte e o Sul da América começarão a surgir ainda no período da colonização. De acordo com David Campbell, os espanhois, portugueses e franceses (...) tentaram incorporar essa população em suas sociedades - apesar da extrema violência exercida contra os colonizados -, enquanto os ingleses sempre evitaram qualquer contato. A presença da mestiçagem no sul e sua ausência no norte será gradualmente utilizada como uma forma de diferenciação entre as duas Américas. No século XIX, as teorias pseudocientíficas sobre mestiçagem e degeneração atuam como uma máquina de diferenciação entre o norte-americano, supostamente branco e puro, e o latino-americano miscigenado e decadente.

O educador e ex-presidente da Argentina Faustino Domingo Sarmiento dizia que os ingleses que povoaram a América do Norte conservaram a pureza de sua psicologia por terem mantido distância dos autóctones. Ao contrário, na América Latina, os espanhóis se misturaram com mulheres indígenas, o que resultou numa degeneração de sua psicologia. Em suma, na visão de Sarmiento, os norteamericanos seriam europeus puros e os hispanoamericanos, europeus decaídos. Mas a inferioridade dos hispanoamericanos não devia ser atribuída apenas aos indígenas, segundo Sarmiento. O próprio espanhol já era um europeu inferior ao anglo-saxão, uma vez que a Espanha que conquista o continente é a Espanha medieval que traz consigo um elemento de atraso e subdesenvolvimento.

No entanto, a tentativa dos norte-americanos de se diferenciarem dos latino-americanos e se apresentarem como uma extensão da cultura europeia nunca foi totalmente compartilhada pelos europeus. Um dos temas do escritor americano, naturalizado britânico, Henry James (1843-1916) foi justamente a distância quase intransponível entre europeus e americanos no século XIX. Em O Americano, Os Europeus e Daisy Miller, entre outras obras, James mostra o embate entre o puritanismo americano e o epicurismo europeu. Neste contexto, os norteamericanos são representados pelos europeus como pouco sofisticados, incultos, vulgares e excessivamente preocupados com dinheiro. 
Esta percepção sobre um hiato entre norte-americanos e europeus reaparece no século XXI. Como lembra T.R. Reid, um quadro do programa britânico Big Breakfast apresenta uma família americana, os Lardburgers, como completamente destituída de classe. Os Lardburguers são obesos, crueis e ignorantes; falam alto e brigam o tempo todo. Os europeus sempre tiveram prazer em ridicularizar os norte-americanos, uma tendência que aparece nas pesquisas de opinião realizadas periodicamente na Europa.

Segundo Reid, o preconceito em relação ao "Outro americano" serviu para unificar os europeus em torno de uma identidade. Este processo se tornou mais intenso após o fim da Guerra Fria, quando tanto os Estados Unidos quanto a União Europeia tentaram se reposicionar no sistema internacional.

Antes da queda do Muro de Berlim, a Comunidade Europeia já debatia a possibilidade de criar um mercado interno para aumentar a competitividade e concorrer com os Estados Unidos. Em 1986, o Ato Único Europeu estabeleceu as etapas para a constituição de um mercado interno em 1992. Com a queda do muro de Berlim em 1989, o projeto de uma moeda única foi apresentado como uma decorrência lógica do mercado interno e considerado um ponto fundamental para a estabilidade e o crescimento econômico da Europa.

Esta iniciativa foi percebida pelos Estados Unidos como um movimento da Europa para construir uma fortaleza econômica. Como reação, o presidente George Bush lançou uma proposta para uma "região americana global de comércio", que passou a ser conhecida como "iniciativa Bush". O objetivo era sinalizar para a Europa que qualquer incremento no protecionismo europeu provocaria uma reação norte-americana, com a possível constituição de uma zona de livre-comércio unindo a América do Norte e a América do Sul.

Mas o projeto europeu não se revelou tão ameaçador quanto os Estados Unidos temiam. O Tratado de Maastricht, assinado em 1992, diferia dos Tratados fundadores em relação à concepção econômica adotada. Enquanto os primeiros eram influenciados por uma visão keynesiana, o novo documento considerava o Mercado Interno e a integração econômica a partir do conceito de regionalismo aberto, ou seja, o mercado interno seria uma etapa para a inserção da União Europeia no processo de liberalização comercial mundial. Desta forma, Maastricht impôs aos Estados-membros um receituário neoliberal composto por baixa inflação, aperto monetário e déficits mínimos. 
Criado em 1991, o Mercosul (Mercado Comum do Sul) também será fortemente influenciado ao longo da década de 90 pelo conceito de regionalismo aberto, principalmente após o relançamento, em 1994, da “iniciativa Bush", renomeada como Alca (Área de Livre-Comércio das Américas). No ano seguinte à proposta da Alca, a União Europeia e o Mercosul negociaram um acordo quadro inter-regional, o qual estabeleceu uma ambiciosa agenda de associação que incluía a formação de uma área de livre-comércio entre os dois blocos num prazo de 10 anos. A partir dessas considerações, podemos concluir que o contexto econômico da última década do século XX se caracterizava pela predominância do neoliberalismo e do regionalismo aberto. Por outro lado, percebe-se que a América Latina oscilava entre o alinhamento com os Estados Unidos e com a União Europeia.

As crises econômicas do final da década - e a decorrente descrença no neoliberalismo - levaram a União Europeia a rever suas estratégias para a América Latina e o Caribe. Um acordo quadro e uma área de livre-comércio não seriam mais suficientes para impulsionar as relações entre o bloco europeu e a América Latina e o Caribe. Era preciso propor algo mais ambicioso, que fosse além da mera troca comercial. O conceito de "associação estratégica birregional" previa uma aproximação em vários campos: econômico, político, social, ecológico, securitário, cultural etc... Ou seja, mais do que uma área de livre-comércio, a associação estratégica propunha a criação de um "espaço birregional” baseado em valores comuns a ambas as regiões. Assim seria possível criar um "espaço de prosperidade e segurança" em contraste com o modelo neoliberal propagado pelo "Outro norte-americano". Neste discurso, o significante "associação estratégica" adquire a conotação de uma "relação privilegiada" entre UE e América Latina e Caribe.

O fim da Guerra Fria trouxe ainda um outro desafio para a União Europeia: o seu reposicionamento político num mundo agora unipolar². A guerra da Bósnia, que começou no mesmo ano (1992) da assinatura do Tratado de Maastricht, revelou o descompasso entre a dimensão política e econômica da União. O mesmo bloco que se preparava para criar um mercado interno e uma moeda única era incapaz de lidar com um conflito em seu entorno e entre possíveis candidatos ao bloco.

\footnotetext{
${ }^{2}$ Em artigo publicado na Foreign Affairs em 1990, Charles Krauthammer referia-se ao "momento unipolar" do sistema internacional, em que a única superpotência era os Estados Unidos.
} 
Entre 1945 e 1989, a guerra entre Estados havia desaparecido da Europa. “Duas gerações de europeus cresceram sob a impressão, até então inconcebível, de que a paz era a ordem natural das coisas" (Judt, 2005, p. 750) e de que o Holocausto nunca mais aconteceria. Norbert Elias apontou para o perigo deste tipo de naturalização ao lembrar que, quando Napoleão conquistou o Egito, os povos europeus passaram a acreditar que a civilização era sua essência natural e não uma conquista precária resultante de uma longa luta. Foi justamente por isso, afirma Elias, que os europeus estavam mal preparados para lidar com a ascensão do nacional-socialismo e de suas políticas genocidas no século XX.

De forma similar, o pós-Segunda Guerra permitiu que, por duas gerações, a paz fosse considerada como a ordem natural das coisas na Europa. Consequentemente, a União Europeia não soube como se posicionar no momento da eclosão da guerra da Bósnia. Uma das estratégias discursivas utilizadas foi a de que os Balcãs eram uma região em que a barbárie tinha raízes históricas. Este discurso permitia que a União Europeia se apresentasse como o "espaço civilizado" onde tais disputas sangrentas não poderiam ocorrer. Entretanto, conforme Hitchcock, "algumas das características que levaram à crise na Iugoslávia existiram e ainda existem em vários lugares da Europa" (2003, p. 380).

Além disso, aquela estratégia discursiva também servia para justificar o não-envolvimento. Se as disputas eram "enraizadas" e "históricas", não havia muito o que fazer. Num primeiro momento, o não-envolvimento era uma forma de afirmar sua própria civilização. Com o decorrer da guerra, no entanto, os países europeus decidem participar das operações de paz sob o comando da ONU. Era uma outra forma de reiterar seu caráter civilizado. Mas a guerra só foi interrompida em 1995 com os bombardeios da OTAN, liderada pelos Estados Unidos. Parecia que a "civilização europeia" não havia sido capaz de conter os "bárbaros" por meio de ações civilizadas como as operações de paz.

A sensação de fracasso na guerra da Bósnia levou os europeus a questionarem o poder militar da Europa. Mais uma vez, estava-se diante da imagem de uma Europa como gigante econômico e anão político. Paradoxalmente, a limitação militar serviu para reforçar uma imagem civilizada que, por sua vez, não deixou de trazer alguns benefícios para a União Europeia. A UE começou a se diferenciar como um espaço pós-nacional, pós-westfaliano, pós-guerra, pós-hobbesiano. Seria "não tanto uma rede de instituições ou um corpus de leis, mas um conjunto 
de valores - "valores europeus" - incorporados na nova Carta de Direitos Fundamentais" (Judt, 2005, p. 735).

A percepção de que "a paz era a ordem natural das coisas" também foi abalada pela necessidade de incorporar os países do Leste Europeu, para os quais a memória do pós-Guerra não poderia ser chamada de pacífica. Nesse sentido, a preparação do alargamento para o Leste nos anos 90 obrigou a União Europeia a reescrever o seu passado e, consequentemente, a sua identidade. Tratava-se então de reafirmar perante os novos membros a imagem da União Europeia como um espaço de prosperidade, segurança, paz, respeito aos direitos humanos e resolução dos conflitos por meio da diplomacia. Em outras palavras, os candidatos à adesão deveriam adotar os "valores europeus" representados pelo chamado acquis communautaire.

Portanto, o lançamento de uma "associação estratégica" com a América Latina e o Caribe em 1999 deve ser compreendido a partir desse contexto político no qual a União Europeia estava às voltas com a redefinição de seu papel e identidade no período pós-Guerra Fria. Em vez de aceitar resignadamente a subserviência aos Estados Unidos - como ficou evidente no caso da Bósnia -, a União Europeia começava a traçar uma estratégia para se posicionar de forma independente no cenário internacional. Para isto, no entanto, seria necessário diferenciar-se do “Outro norte-americano", aproximando-se de uma América Latina que compartilhasse seus valores.

Este movimento de oposição europeia aos Estados Unidos será momentaneamente estancado no período imediatamente posterior ao 11 de setembro. Algumas horas depois do ataque, o primeiro-ministro Tony Blair declarou sua solidariedade aos americanos. Até o jornal tradicionalmente anti-americano Le Monde estampou em sua manchete: "somos todos americanos". Uma pesquisa realizada pela companhia suíça Isopublic revelou que $80 \%$ dos dinamarqueses, $79 \%$ dos britânicos, $73 \%$ dos franceses, $58 \%$ dos espanhois e noruegueses e $53 \%$ dos alemães aprovavam a participação de seus países num ataque militar americano. Em suma, o ataque às Torres Gêmeas e ao Pentágono pode ser lido como a irrupção de um acontecimento histórico que desestabilizou o quadro de inteligibilidade segundo o qual o americano era cruel, ignorante e belicoso. O americano passou a ser visto então como justo, inocente e digno. Fazia então sentido lembrar que a Aliança Atlântica havia sido construída com base na ideia de valores comuns - liberda- 
de, democracia, direitos humanos - entre os Estados Unidos e a Comunidade Europeia.

No entanto, este apoio incondicional durou pouco. Um ano depois dos ataques, políticos, colunistas e acadêmicos europeus descreviam os Estados Unidos como egoístas que insistiam em tomar ações unilaterais. A administração Bush fortaleceu todos os velhos preconceitos e estereótipos sobre os Estados Unidos. Nas palavras de T.R. Reid, o Atlântico começava a se alargar. A imagem dos Estados Unidos deixava de ser a de protetor do continente europeu e se transformava em ameaça.

Em 2003, Robert Kagan defendeu em Do Paraíso e do Poder a tese de que a América e a Europa são fundamentalmente diferentes e estão se tornando cada vez mais distantes à medida que os Estados Unidos acumulam poder militar e os europeus buscam sua superação por meio da cooperação internacional. Neste sentido, os americanos estariam ainda no mundo da história e da política de poder, enquanto os europeus viveriam num paraíso kantiano pós-moderno e a-histórico. Kagan lembra que nem sempre foi assim. Até a Segunda Guerra Mundial, a situação era inversa: os europeus, ainda hegemônicos, praticavam a política de poder. Já os Estados Unidos defendiam a cooperação. Para Kagan, o não-hegemônico sempre optará pela cooperação e discursará contra o uso da força.

Mesmo os críticos de Kagan reconheceram que sua teoria do afastamento e de uma diferença intrínseca entre Estados Unidos e União Europeia estava correta. As discordâncias surgiam quando a Europa era apresentada como fraca e decadente. Os europeus reagiram a este diagnóstico e inverteram a oposição: a Europa seria forte justamente por promover uma nova ordem internacional mais civilizada, sem precisar recorrer à força.

Em repúdio à Guerra do Iraque, Jürgen Habermas e Jacques Derrida assinaram em 2003 uma declaração intitulada "After the War: the rebirth of Europe”, na qual exortam a Europa a contrabalançar o unilateralismo dos Estados Unidos. Ainda que isto não fosse dito claramente, os dois filósofos buscavam a criação de uma "identidade europeia" capaz de rivalizar com a postura norte-americana pós11 de setembro. No texto, a Europa é apresentada, em contraste com os Estados Unidos, como a região que conseguiu superar a história de chauvinismo nacional e militarismo, destacando-se hoje pela defesa da lei internacional como forma de resolução dos conflitos. O manifesto também faz uma diferenciação entre euro- 
peus e americanos em relação ao conceito de igualdade. Enquanto os americanos definem a igualdade segundo a concepção liberal de tratamento justo perante a lei, os europeus a entendem como "igualdade relativa ao padrão de vida".

$\mathrm{O}$ argumento de que Derrida não teria concordado totalmente com o texto de Habermas se enfraquece quando nos deparamos com um outro texto de Derrida no qual ele convoca a Europa "a assumir o papel que lhe cabe na construção de uma outra globalização. (...) Nós devemos lutar pelo que a Europa conserva de insubstituível no mundo que está por vir" (Derrida, 2004, p.1). Derrida acrescenta que a Europa deveria se tornar "o motor de uma outra globalização, seu laboratório" (loc.cit) e clama por "uma Europa que mostre o exemplo do que pode ser uma política, uma reflexão e uma ética herdeiras do Iluminismo passado e portadoras do Iluminismo vindouro" (Derrida, 2004, p. 1). ${ }^{3}$

$\mathrm{O}$ fato de dois pensadores filosoficamente opostos concordarem sobre a necessidade de um renascimento do continente atesta a força da "Ideia de uma Europa" capaz de recuperar a posição perdida no cenário mundial entre 1945 e 1989. Habermas e Derrida reproduzem no manifesto um discurso sobre a Ideia de Europa que vem sendo repetido nos mais variados círculos intelectuais desde o fim da Guerra Fria.

Nos debates acadêmicos de relações internacionais, a União Europeia é tradicionalmente considerada "como um tipo distintamente diferente de ator internacional. Ao longo dos anos, a União Europeia tem sido descrita como um poder civil, soft power e, mais recentemente, um poder normativo nas relações internacionais" (Tocci, 2008, p. 1). De acordo com Ian Manners, a União Europeia seria um "ator de política externa que molda, instila, difunde - e assim normaliza - regras e valores em assuntos internacionais por métodos não coercitivos" (Manners apud Tocci, 2008, p.2). Os textos oficiais da União Europeia reforçam essa percepção ao fazerem explicitamente referência a um papel diferenciado da União Europeia no sistema internacional. Esta atuação internacional seria influenciada pela identidade da União Europeia, apresentada como virtuosa, pós-moderna, distante da política de poder e do jogo de soma zero. A Europa estenderia à sua política externa os valores que a constituem como um ator internacional "sui generis".

\footnotetext{
3 A defesa do Iluminismo por Derrida parece entrar em contradição com a sua obra sobre a desconstrução. Na seção sobre metodologia, voltaremos a esta questão para tentar examinar em que medida a desconstrução pode ser usada contra o próprio texto de Derrida em defesa de uma ideia de Europa.
} 
Miroslav Milovic refere-se ao "atual discurso sobre a grandeza europeia" (Milovic, 2007, p. 47). Na apresentação de uma palestra do crítico literário George Steiner, realizada no Instituto Nexus em 2004, o diretor da instituição, Rob Riemen, inicia a discussão com a pergunta sobre se a Europa "continua ou não a ser uma boa ideia e qual é realmente a importância e relevância política do ideal europeu de civilização" (Riemen, 2004, p. 12). A cultura europeia é descrita por Riemen como "essencialmente cosmopolita" (Riemen, 2004, p.12). Steiner reitera a necessidade de recuperar o que ele chama de "a ideia de Europa", a qual estaria baseada num humanismo secular:

(...) nas garras do fundamentalismo assassino - seja ele o do Sul e Centro americanos, ou seja o do Islã _, a Europa ocidental pode ter o privilégio imperativo de produzir, de pôr em prática, um humanismo secular. Se conseguir libertar-se da sua própria herança negra, (...) pode, uma vez mais, indicar o caminho a seguir (Steiner, 2004, p. 52).

Steiner constroi neste parágrafo uma ideia de Europa baseada em uma memória seletiva dos fatos históricos. Apesar de reconhecer a existência de uma herança negra, o autor associa a Europa ao humanismo secular, como se esta fosse a força predominante na história do continente. Já o fundamentalismo é localizado "no Sul e Centro americanos" e "no Islã", ignorando outras correntes de pensamento presentes nestes locais. Em suma, a seletividade histórica empreendida por Steiner atribui identidades fixas e redutoras à Europa, ao sul e centro americanos e ao Islã. O que se depreende deste discurso é uma tentativa de representar a Europa como a "salvadora da civilização" num mundo repleto de Outros fundamentalistas (uma parte dos Estados Unidos e o Islã).

Peter Sloterdijk também detecta o renascimento de um discurso sobre a grandeza civilizacional da Europa. Cada vez se ouve com mais frequência a tese de que "o estupor europeu e, principalmente, alemão depois de 1945 não podia ser um estado definitivo, e que a fase do encolhimento entre as novas superpotências só pode ter o caráter de uma moratória" (Sloterdijk, 2002, p. 33). Na avaliação do autor, parece quase inexorável o retorno da Europa pois o princípio do poder mundial residiria em suas raízes. O momento de vácuo e letargia de 1945-1989 teria nos dado a impressão equivocada de que "o ímpeto do movimento histórico teria definitivamente desenvolvido novos centros de ação no Leste e no Oeste" (Ibidem, p. 36). Ao contrário, a essência da Europa estaria num mecanismo de 
transmissão imperial, ou seja, a Europa mantém-se em movimento porque reivindica, reencena e transforma o Império. Depois de transferir o poder para os Estados Unidos, a Europa estaria hoje disposta a retomar sua essência imperial? Na visão de Sloterdijk, este não seria o melhor caminho. Em vez de reproduzir o modelo de poder imperial, os europeus deveriam "submeter a uma metamorfose histórica o próprio princípio da grande potência ou do Império. (...) A Europa será o seminário onde os homens aprendem a pensar para além do Império" (Ibidem, p.62). Embora Sloterdijk tenha uma visão crítica sobre uma nova Europa imperial, sua solução não deixa de ser uma tentativa de recentramento da Europa. Ao assumir a tarefa de inovação, seminário ou laboratório, o continente estaria recuperando seu papel de provedor de um modelo para o mundo.

As referências a um renascimento da Europa abundam na literatura do período pós-Guerra Fria. Segundo David Marquand, a Europa passou por um processo de auto-congratulação nos anos 90, em que parecia que o vazio apontado por Sloterdijk seria enfim preenchido por um novo projeto europeu. O sucesso europeu em persuadir Estados nacionais a transferirem parte de sua soberania para a União Européia era apresentado como um modelo digno de ser repetido em outras regiões. A vocação da Europa seria levar a mensagem deste sucesso para o resto da humanidade. Para Ulrich Beck, a frase que resumia o futuro era algo como "esqueça a América, a Europa está de volta" (Beck apud Marquand, 2011, p. 24).

De acordo com Mark Leonard, a Europa iria liderar o século XXI por meio de um novo tipo de poder, não o poder estritamente militar considerado por Kagan, mas um "poder transformador" que deixaria de lado vitórias militares de efeito efêmero e atuaria a longo prazo redesenhando o mundo. O poder europeu estaria muito mais ligado à sua capacidade de difusão de tratados, constituições e leis do que à posse de armamentos. Desta forma, ela teria possibilidades de expandir sua influência sem provocações.

Os países estão se inspirando no modelo europeu e alimentando seus próprios projetos, da Asean e do Mercosul à União Africana e à Liga Árabe. (...) Veremos o nascimento de um 'Novo Século Europeu'. Não porque a Europa vai dominar o mundo como um Império, mas porque a forma europeia de fazer as coisas se tornará a forma do mundo fazer as coisas (Leonard, 2005, p. 1). 
Leonard reproduz nesta passagem uma tese similiar à de Sloterdjk. A Europa não dominará por impulso imperial, mas "pelo exemplo". O caráter normativo da política externa e da ideia de Europa continuam presentes. Nos dois casos, estamos diante de discursos autocongratulatórios, que recentralizam a Europa e o seu papel no mundo. Na próxima seção, veremos como Mark Leonard mudou de ideia com a ascensão da China. Em 2008, o autor afirmou que o século XXI será da China.

Portanto, a exortação de Habermas e Derrida por um renascimento da Europa assim como a sugestão de Steiner de que a Europa pode mostrar o caminho a seguir devem ser compreendidas no contexto do debate sobre a "ideia de Europa". Segundo Stefan Elbe, a "ideia de Europa" traz em si o conceito de "vitalidade espiritual". Este significaria a "habilidade de uma cultura em identificar significados comuns e abrangentes" (Elbe, 2001, p. 8), o que é imprescindível para a criação de uma ordem mundial.

De acordo com Gerard Delanty, a ideia de Europa apareceu vinculada, ao longo dos séculos, a um ideal platônico imutável. Aqueles que acreditavam nesta tese tendiam a associar a Europa a valores como liberdade, democracia e autonomia. Karl Jaspers, por exemplo, referia-se a um "espírito europeu”, enquanto T.S. Eliot defendia uma "tradição essencialmente europeia" (Delanty, 2002, p.1). Para Delanty, estas concepções do século XX formam ainda hoje um consenso bastante difundido. Por isso, o autor sugere uma desconstrução da ideia de Europa como ideal platônico imutável. A ideia de Europa "sempre esteve em um processo de invenção e reinvenção determinado pela pressão de novas identidades coletivas" (Delanty, 2002, p.1).

Dito de outra forma, a ideia de Europa não é uma substância misteriosa pairando acima da sociedade e da história. Em vez de ser simplesmente um sujeito da história, a Europa é produto da história. A partir de uma perspectiva pósestruturalista, a ideia de Europa não existe como substância, mas é um construto constantemente moldado por práticas discursivas.

Pode-se dizer que a Ideia de Europa constitui hoje, na União Europeia, um discurso cultural hegemônico, produtor de consensos. A partir de Foucault, poderíamos dizer que a Ideia de Europa faz parte de uma formação discursiva hegemônica, na qual a Europa "não é algo que possa ser facilmente escolhido ou rejeitado, pois é ela que estrutura o campo das escolhas e a moldura epistemológica na qual 
as escolhas são articuladas" (Ibidem, p. 6). Como consequência deste discurso hegemônico, a ideia de Europa tenderia, como a ideia de nação em outras épocas, a ser reverenciada e sacralizada. Porém, a ideia de Europa não tem o mesmo apelo emocional da ideia de nação.

Essa proximidade entre as ideias de Europa e Nação na verdade contrariam as teses tradicionais que apresentam a Europa como representante de um cosmopolitismo e, portanto, como uma alternativa para o nacionalismo extremado. O que se vê é uma transferência da deificação da Nação para a Europa. Neste sentido, argumenta Delanty, a Ideia de Europa não minou a ideologia nacionalista, mas reforçou-a. A Europa não teria, portanto, se libertado de sua "herança negra", como pensava Steiner (2004, p.52).

Nos últimos 10 anos, as manifestações nacionalistas e xenofóbicas parecem ter confirmado a suspeita de Delanty. Recentemente, a crise econômica de 2008 e a recaída de 2012 apenas contribuíram para acirrar e tornar mais visível a tendência chauvinista e xenófoba. Assim, em lugar da Ideia de Europa cosmopolita, aberta ao outro, vemos cada vez mais a afirmação da Ideia de "Fortaleza Europa", estimulada pelo debate sobre a revisão do Acordo de Schengen.

De certa forma, a ideia de Europa como "Fortaleza" ganhou espaço depois da consolidação, nos anos 90, da ideia de Europa como “força motora por trás (...) da substituição de um tradicional programa social democrata por um programa político neoliberal" (Delanty, 2002, p.9). Em outras palavras, a crise econômica de 2008, provocada e gestada por políticas neoliberais em curso na União Europeia, acabou por fortalecer sentimentos anti-imigração. Além disso, as políticas de austeridade adotadas pela União Europeia para conter a crise estão aprofundando a xenofobia.

Como vimos em Manners, a política externa da UE se baseia em seus valores, numa certa imagem e ideia de Europa. No entanto, a tradição da ideia de Europa pressupõe um modelo universal que deveria ser seguido pelas demais nações. Como veremos em outra seção deste capítulo e no capítulo teórico, a Ideia de Europa está embasada numa concepção de história etnocêntrica, em que a Europa exporta seus valores supostamente universais para os outros, os mais atrasados que precisam alcançar o nível de desenvolvimento material e espiritual mais avançado. Immanuel Wallerstein alerta para o fato de este universalismo ser, na verdade, um "universalismo europeu", o que significa dizer um "particularismo euro- 
peu". A estratégia do discurso hegemônico é justamente transformar a particularidade em universalidade, apresentando os seus interesses particulares como universais.

Tendo em vista este contexto, argumentamos que a "associação estratégica" entre a União Europeia e a América Latina/Caribe não se limita a um acordo entre as duas partes, mas também constrói os "Outros" do sistema internacional. A associação estratégica tentaria moldar uma ordem mundial mais benevolente e justa, inspirada na Ideia de Europa e no universalismo europeu. Os "Outros" do sistema internacional seriam aqueles passíveis de receber os valores da associação estratégica.

No entanto, a lógica reproduzida na escala inter-regional é a mesma que presidiu a formação do Estado moderno, ou seja, a distinção inside/outside. A deificação do Estado, como vimos em Delanty, transfere-se para o espaço da União Europeia e, posteriormente, para o da associação estratégica. As declarações constroem o mundo exterior como um lugar perigoso, o que justificaria a criação de uma associação birregional para proteger seus integrantes dos riscos do outside.

Reproduzindo o modelo do Estado moderno, a associação birregional é construída discursivamente como moralmente superior ao outside anárquico por promover os valores ligados à ideia de Europa: integração, democracia, liberdade individual, lei, segurança, direitos humanos, progresso e justiça. Portanto, a associação estratégica está perpassada pela Ideia de Europa. Ambas as regiões são repositárias da Ideia de Europa. São apresentadas como boas e generosas, detentoras de obrigações morais e intenções benignas e, por isso, capazes de contribuir para a criação de uma ordem mundial mais justa. Temos, portanto, um desnivelamento moral entre o inside e o outside, em que o primeiro é moralmente superior ao segundo.

Em 2002, o ex-Comissário de Comércio da União Europeia Pascal Lamy declarou que o objetivo último da associação estratégica era que "a UE e a América Latina jogassem um papel fundamental no desenho do mundo do futuro" (Lamy apud Úbeda, 2002, p. 120). No entanto, a América Latina/Caribe teria um papel de coadjuvante nesse projeto, já que o próprio Lamy insiste na necessidade de "exportação" do modelo europeu. Não se trata da exportação de um modelo europeu-latino-americano-caribenho que ganharia sua expressão na associação 
estratégica, mas de um "modelo europeu", para o qual a América Latina e o Caribe contribuiriam como atores secundários.

Na visão de Lamy, poderíamos dizer, tomando emprestado um conceito de Derrida, que a América Latina funcionaria como um suplemento da Europa. Em Derrida, o suplemento tem dois significados: 1) ele é um extra não-essencial, que é acrescentado a algo completo. 2) Ao mesmo tempo, esse extra vai completar o que supostamente já era completo em si mesmo. De acordo com esta interpretação, a América Latina e o Caribe preencheriam a função de suplemento na medida em que seriam "atores secundários", um "extra" que contribuiria para o projeto europeu de criar uma nova ordem. Por outro lado, algo parece faltar à União Europeia, caso contrário ela não necessitaria recorrer ao "extra", ao "suplemento" representado pela América Latina. Esta lógica paradoxal perpassa a relação entre a União Europeia e a América Latina e o Caribe.

A pergunta que orientará nossa pesquisa decorre do contexto acima analisado. Qual o papel da América Latina e do Caribe no discurso europeu sobre a constituição de uma identidade europeia - e de uma associação estratégica - capaz não só de se contrapor aos Estados Unidos, mas também de criar uma ordem mundial alternativa? Por outro lado, qual o lugar que a Europa ocupa no discurso latino-americano sobre a associação estratégica birregional? Em que medida essa associação com a Europa não serve à região da América Latina e do Caribe como instrumento para associarem seus valores à cultura europeia e, desta forma, se projetarem internacionalmente como civilizados?

As declarações assinadas nas seis cúpulas realizadas entre a União Europeia e a América Latina (Rio, 1999; Madri, 2002; Guadalajara, 2004; Viena, 2006; Lima, 2008; Madri, 2010) apresentam as duas regiões como iguais, unidas pelos mesmos valores e por uma história em comum. Um exemplo desta proximidade seria o fato de a União Europeia e a América Latina/Caribe privilegiarem o uso da lei internacional como meio para a solução de conflitos. Desta forma, a América Latina e o Caribe seriam os parceiros ideais para a União Europeia levar à frente seu projeto de reposicionamento no cenário mundial. Do ponto de vista da América Latina e do Caribe, a União Europeia seria o aliado perfeito para reforçar sua imagem de zona de paz, defensora da lei internacional e promotora de uma ordem internacional mais justa.

Para o escritor mexicano Carlos Fuentes: 
A Europa e a América Latina poderiam dar o exemplo: a liberdade para a movimentação de capitais e de mercadorias não basta. A globalização só merecerá este nome quando incluir a livre circulação de pessoas e a divisão do trabalho sem fronteiras (2003, p.1).

Podemos notar que a pretensão de "dar o exemplo" não é algo que se restrinja apenas à Europa. No discurso de Fuentes, vemos que o autor acredita numa associação entre a Europa e a América Latina capaz de "dar o exemplo". O texto é omisso em relação àqueles que tomariam a Europa e a América Latina como exemplos. No entanto, subentende-se que as duas regiões seriam um exemplo para todos os outros Estados do sistema internacional. Ao tratar da declaração de independência americana, Derrida nos lembra que nunca se assina uma declaração para si mesmo. A declaração é sempre um documento para os outros. As declarações de cúpula entre a União Europeia e a América Latina seriam, portanto, muito mais do que um documento destinado a reger as relações dessas duas regiões. Ao contrário, elas teriam um caráter pedagógico e normativo, ao mostrar a associação birregional como um exemplo para os demais.

\subsection{2}

\section{O não dito da associação estratégica: a América Latina ainda é o "Outro" da Europa}

Como veremos mais detalhadamente ao longo desta tese, a análise dos documentos de cúpula mostra que, paralelamente à ideia de uma proximidade entre duas regiões que compartilham os mesmos valores (seção anterior), permanece no discurso europeu a visão sobre a América Latina e o Caribe como o "Outro" bárbaro, atrasado, arcaico, aprendiz. As declarações vão confirmar a avaliação de Wanderley Guilherme dos Santos:

Na perspectiva de uma geografia humana europeia, a América Latina ainda se confunde com o Oriente dos mapas cartográficos quinhentistas - uma espécie de ápeiron sociológico, habitado por mutantes, rebentos da transplantação de estoques europeus a regiões inóspitas à civilidade, retardatários da civilização (2007, p. 50).

Fernando Coronil confirma esta interpretação ao mostrar que a área que se tornou a América Latina tem sido descrita como "diferente e inferior em diferen- 
tes períodos históricos, de acordo com a tipologia dominante: selvagem, primitivo, atrasado, tradicional, subdesenvolvido, em desenvolvimento, Terceiro Mundo, emergente, falido" (2011, p. 246).

No entanto, o paradoxo do discurso europeu sobre a América Latina/Caribe é que a região é vista, ao mesmo tempo, como semelhante (um "outro Ocidente" segundo a formulação de José Guilherme Merquior ou "extremo ocidente" conforme sugestão de Alain Rouquié) e como diferente (o Oriente dos mapas cartográficos quinhentistas, nas palavras de Santos). Esta ambiguidade no tratamento da América Latina/Caribe nos lembra o conceito de "duplo movimento" desenvolvido por Tzvetan Todorov. Ao nos depararmos com a diferença, diz o autor, realizamos um duplo movimento: a assimilação e a inferiorização. Por um lado, a América Latina/Caribe é considerada como semelhante depois de assimilar os valores europeus. Por outro, ela é vista como inferior e as inferiorizações ganham expressão nas oposições hierárquicas Ocidente/Oriente, civilizado/bárbaro, desenvolvido/em desenvolvimento, moderno/arcaico, europeu/latino, racional/irracional.

O próprio discurso latino-americano por vezes incorpora essas oposições hierárquicas, reconhecendo-as como válidas. Este processo de incorporação acrítica do discurso de saber do outro sobre nós foi descrito por Walter Mignolo como “colonialidade do saber". Porém, como veremos no capítulo teórico, é possível desconstruir e descolonizar o saber por meio de uma estratégia antropofágica.

Na próxima seção (2.3.3), pretendemos discutir dois processos, o da constituição da identidade europeia em relação ao outro latino-americano, a partir da leitura de Aníbal Quijano, e a forma como a identidade latino-americana relaciona-se com a europeia, expressa pela sensação de "não- estar de todo" (Flora Süssekind) e pelo conceito de entre-lugares (Silviano Santiago).

\subsection{3}

\section{A Europa só se constitui como tal a partir da "descoberta" da Améri- ca}

Sem nós a Europa não teria sequer a sua pobre declaração dos direitos do homem. 
Nesta seção, apresentamos o recorte temporal da pesquisa, sem, no entanto, aprofundar a discussão teórica. Esta será feita no capítulo seguinte, na seção sobre a concepção de história pós-fundacionalista e pós-colonialista.

Se a Europa sempre se constituiu a partir de seus Outros, como afirma Neumann, qual o lugar da América Latina nessa formação? Será que a América Latina poderia ser configurada como um dos Outros da Europa no século XXI ? Ou poderíamos dizer que a América Latina tem pouca importância para a Europa neste século, já que o continente estaria mais preocupado com os Outros que vêm da África e do Mundo Islâmico?

Na análise de Aníbal Quijano e Walter Mignolo, Europa e América produziram-se, histórica e mutuamente, como as duas primeiras novas identidades geoculturais do mundo moderno. “A América como construto geosocial também nasceu ao longo do século XVI. A criação de sua entidade geosocial foi o ato fundacional do sistema-mundo moderno" (Quijano, Wallerstein apud Mignolo, 2007, p. 70). Disto decorre que a América não se incorporou a uma economia-mundo capitalista prévia. Ao contrário, ela foi condição para o surgimento da economiamundo capitalista.

No entanto, ao longo dos séculos, a História eurocêntrica tem apresentado uma narrativa na qual a Europa aparece como autoengendrada e a América é simplesmente descoberta por um sujeito europeu que já existiria previamente (ver a concepção de história discutida no capítulo teórico). Esta versão originou-se no Humanismo europeu dos séculos XV e XVI e se legitimou academicamente no século XIX, a partir de uma concepção de história linear e evolutiva na qual a Europa ocupava o ponto final. Prevalece, portanto, na história universal, um silenciamento sobre a co-constituição identitária entre a Europa e a América Latina e, consequentemente, sobre como a América Latina se tornou um "Outro" para a Europa, um outro em relação ao qual o europeu começa a delinear sua identidade.

Sem a América, sem o conhecimento de formas de existência social baseadas na igualdade social, a reciprocidade, a comunidade, a solidariedade social de algumas sociedades indígenas pré-coloniais, em especial na região andina, não se poderiam explicar as utopias europeias dos séculos XVI, XVII e XVIII (Quijano, 2006, p.73).

A co-constituição aponta também para uma con-temporaneidade entre a América Latina-Caribe e a Europa. Os tempos e as histórias das duas regiões não 
estão numa sequência unidirecional, mas fazem parte de um único mundo moderno em plena formação. A Europa Ocidental, diz Quijano, é formada sobre o fundamento da América. Aqui lembramos a conclusão de Octavio Paz em "Labirinto da Solidão" sobre a con-temporaneidade da América Latina: "Pela primeira vez na história, somos contemporâneos de todos os homens" (apud Santiago, 2006, p. 17). Neste aspecto, Quijano é bem mais radical do que Paz. A contemporaneidade não é de agora; remonta ao século XVI. Sempre fomos contemporâneos.

É importante distinguir aqui o texto e o contexto e, ao mesmo tempo, mostrar sua interação ${ }^{4}$. O contexto do século XVI, como apontado por Quijano, tornava a Europa e a América contemporâneas, parte de um mesmo mundo. Porém, o discurso europeu sobre a América já relegava então a região a um passado imemorial, idílico, fora da história ou anterior ao da história europeia. Paradoxalmente, era justamente a contemporaneidade entre as duas regiões que criava as condições de possibilidade para um discurso etnocêntrico sobre a linearidade da história. A diferença na contemporaneidade incomodava de tal forma que ela precisava ser enquadrada e neutralizada no passado ${ }^{5}$.

O novo sistema de dominação social inaugurado pela modernidade no século XVI baseou-se na categoria social de raça. Esta era utilizada, segundo Quijano, para naturalizar e legitimar as novas relações de poder impostas aos sobreviventes. Em vez de atribuir a derrota dos índios a um conflito de poder, o discurso racialista localiza a causa do massacre dos índios em sua inferioridade natural. A partir de uma abordagem pós-estruturalista, poderíamos dizer que não há precedência do material em relação ao discursivo, mas uma concomitância entre o material e o discursivo. Quijano argumenta que, por ser um construto mental, a classificação racial "não seria nem sequer imaginável fora da violência da dominação colonial" (2006, p. 66). Mas a violência também não seria imaginável fora do discurso. É a racialização que tenta emprestar um sentido à violência contra o outro.

O recorte temporal de Quijano, que adotamos nesta pesquisa, localiza o início da modernidade no século XVI, justamente a partir da "descoberta" da América. Entendemos que a localização do início da modernidade no século XVIII, a partir da Revolução Francesa, obedece a uma visão etnocêntrica da histó-

\footnotetext{
${ }^{4}$ Esta questão será discutida no capítulo teórico.

${ }^{5}$ Como veremos no próximo capítulo, o discurso europeu sobre a América é tributário da Filosofia da História Hegeliana, que localizava a América fora da história.
} 
ria. Além de silenciar a contribuição da América Latina para a formação do mundo moderno no século XVI, este recorte histórico associa a modernidade a uma determinada forma de racionalidade.

O que Mignolo irá chamar de "colonialidade do saber" é justamente a aceitação, por parte da América Latina, daquele recorte histórico etnocêntrico. Até o começo do século XX, a América parece admitir a ideologia eurocêntrica sobre a modernidade como verdade universal, o que implicava a "invisibilidade sociológica dos não-europeus, 'índios', 'negros' e seus 'mestiços' (...) a respeito da produção de subjetividade, de memória histórica, de imaginário, de conhecimento 'racional"'(Quijano, 2006, p. 78). Este foi o período em que, como dizia Leopoldo Zea, a América era apenas o monólogo da Europa.

Porém, este processo de invisibilização do outro não ocorre de forma linear. Como veremos adiante, "o reprimido retorna sob outra forma” (Santiago, 2006, p. 10). As relações intersubjetivas entre dominadores e dominados criou, aos poucos, um universo cultural considerado "híbrido", sendo que híbrido não significa aqui uma mistura entre duas identidades. Como veremos no capítulo teórico, o híbrido não equivale a uma síntese. Ele estaria mais próximo do conceito de indecidibilidade de Derrida e do operador "entre-lugares" de Silviano Santiago. Ou seja, a identidade latino-americana passou a ser um terreno de indecidibilidade entre o europeu e o não-europeu.

Mas, ainda aqui estamos embebidos na colonialidade do saber, uma vez que o modelo continua sendo o europeu, a partir do qual se faz a diferenciação entre o europeu e o não-europeu. O não-europeu - índios, negros e mestiços aparece como uma negação do polo positivo, identificado como europeu. A própria categoria "europeu” apresenta cisões. Há uma máquina de diferenciação de significado atuando dentro desta categoria. O que se entendia por europeu no século XVI englobava ou excluía o ibérico? A resposta dependerá do ponto de vista que se adote sobre a modernidade:

Poderíamos considerar que o discurso europeu sobre a América Latina é ambíguo porque há uma "máquina de diferenciação" entre o ibérico e o europeu. Nesta leitura, a Ibéria seria responsável por promover uma aproximação com a América Latina, enquanto a Europa continental produziria o afastamento. Neste caso, teríamos dois discursos em confronto na Europa, um produzido pela Ibéria, enfatizando os valores comuns e propondo maior aproximação, e outro provenien- 
te da Europa continental, marcando um afastamento em relação ao continente latino-americano.

Essa versão aposta num certo afastamento da Península Ibérica e, consequentemente, da América Latina, em relação ao continente europeu. As análises sobre a especificidade da Ibéria costumam desembocar na conclusão de que a "diferença ibérica" foi contida pelos Pirineus. De fato, o conceito de modernidade pós-Iluminista relega a Ibéria a uma posição secundária na formação europeia, não só isolando-a, mas negando-lhe qualquer interferência no desenvolvimento histórico do continente.

Este descolamento da Ibéria em relação ao continente europeu irá aparecer tanto no discurso europeu que considera a Ibéria e a América Latina como os “Outros bárbaros" da Europa quanto no discurso latino-americano que simplesmente inverte a hierarquia anterior e afirma a superioridade ibérica e latina. A ideia de uma distinção entre os europeus remonta a Hegel, que distingue o Norte e o Sul da Europa. Os países do sul da Europa não carregariam o desenvolvimento em sua constituição e deveriam ser "ajudados" pelos países do norte.

Uma outra possibilidade seria afirmar o papel da Ibéria na formação da Europa e do discurso europeu. A Ibéria teria influenciado a formação da modernidade europeia no século XVI e, consequentemente, o discurso europeu deste período sobre a América. A Europa como um todo - e não apenas a Ibéria - teria traços em comum com a América Latina. Por outro lado, esta mesma Europa percebe a si mesma como distante da América. Existe, portanto, uma contradição no discurso produzido pela Europa pois uma parte dele se aproxima da América, enquanto a outra dela se afasta.

A tese sobre a influência da Ibéria na formação da modernidade europeia é compartilhada por autores como Quijano, que destaca a co-constituição identitária entre a Europa e a América Latina. O papel da Europa na constituição da América Latina não é um processo unidirecional; o contrário também ocorreu, ou seja, a América Latina também influenciou a construção do imaginário do moderno sistema mundial. Como sugere Chakrabarty, é preciso considerar a interseção de ambos os lados da modernidade. O Terceiro Mundo contribui para a Modernidade da mesma forma que esta o produz.

O filósofo argentino Enrique Dussel (1992) chama a atenção para o fato de que o início da modernidade planetária e europeia é uma consequência da "desco- 
berta" da América e do estabelecimento do circuito comercial e financeiro do Atlântico. Walter Mignolo reforça o argumento de Dussel: "a conexão do Mediterrâneo com o Atlântico através de um novo circuito comercial, no século XVI, lança as fundações tanto da modernidade quanto da colonialidade" (2003, p.81).

Com a localização da modernidade no século XVI, Quijano, Dussel e Mignolo, entre outros, afirmam a presença da herança ibérica na formação europeia. Ao contrário, o conceito de modernidade criado no século XVIII obscurece a agência exercida pela periferia ibérica na formação do imaginário moderno europeu e da identidade europeia. Um exemplo desta articulação está no fato de que é apenas com a conexão do circuito Atlântico que os árabes se transformam no "outro" contra o qual se constitui a identidade europeia no início da modernidade.

Ao tratar do neotomismo na formação da Ibéria, Rubem Barboza Filho mostra como Portugal e Espanha ocuparam "o centro do mundo ocidental, tornando-se responsáveis por grande parte dele, no momento de dissolução das antigas sínteses racionalizadoras construídas pela cristandade" (2000, p. 278). A tarefa reflexiva empreendida pela Ibéria teria tido impactos profundos nas dimensões religiosa e política do mundo europeu.

Com base nesta interpretação, diríamos que o discurso europeu do século XVI sobre a América Latina não é produzido apenas na Península Ibérica. Ao contrário, "o escândalo" do Novo Mundo provoca um impacto que não se limita à Ibéria, mas estende-se a todo o continente europeu. Portanto, o discurso europeu sobre a América Latina no século XVI não pode ser senão um discurso comum a todo o espaço geográfico europeu.

Em Jangada de Pedra, José Saramago relata o desgarramento da Península Ibérica do restante da Europa, o que reforçaria a primeira hipótese, ou seja, a de um afastamento da Península Ibérica em relação à Europa. No entanto, a história contada pelo escritor mostrará que esta hipótese não é tão inequívoca pois, num determinado momento, descobre-se num muro localizado no continente europeu (do qual a Península Ibérica já se separou) a inscrição "Nous aussi, nous sommes ibériques" (Saramago, 1986, p.140), supostamente escrita por francófonos. A frase será repetida nas várias línguas dos outros países europeus, insinuando uma herança ibérica que teria se expandido pela Europa. "Somos todos ibéricos !", bradavam os europeus no romance de Saramago. 
Defender um isolamento da Ibéria em relação à Europa nos parece um tanto exagerado. A Ibéria funcionaria antes como um "território-ponte" (Buarque de Holanda, 1995, p.31) por meio do qual "a Europa se comunica com os outros mundos" (Idem). Espanha e Portugal representam uma zona de fronteira, onde o europeísmo se manifestaria de forma mais suave. O ibérico, por sua vez, também é submetido a uma máquina de diferenciação, como aponta Santiago em sua análise sobre "Raízes do Brasil", de Sérgio Buarque de Holanda. O brasileiro se diferencia do hispânico por ser semeador, aventureiro e desleixado. O lema do semeador seria “colher o fruto sem plantar a árvore”. Já o hispânico é associado ao ladrilhador que reduplica no Novo Mundo a geometria e a racionalidade das cidades espanholas, preocupando-se mais em construir do que tirar proveito do que encontra pela frente. Há, portanto, uma cisão - e hierarquização - no mundo ibérico.

\subsection{4}

\section{A sensação de "não estar de todo" e a antropofagia}

Em O Brasil não é longe daqui, a crítica de literatura Flora Süssekind anlisa o desconforto de nossa "sensação de não estar de todo", que significaria um não pertencimento, uma sensação de inadequação ao lugar. Ou, como diria Mário de Andrade, a "moléstia de Nabuco", que vem a ser esse hábito de "vocês [brasileiros] andarem sentindo saudade do cais do Sena em plena Quinta da Boa Vista” (apud Santiago, 2006, p. 104). Esta sensação ocorreria, segundo Süssekind, porque desde sempre nosso olhar sobre nós mesmos se constituiu a partir de fora.

Alguns exemplos podem ser encontrados na pintura do século XIX, cujos artistas eram instruídos nas perspectivas, nas técnicas e nos mapas europeus. Só após uma longa estadia de aprendizado na Europa ou de uma formação sob os cuidados de um professor europeu, estava o artista brasileiro apto a pintar nossa paisagem. "Aprendemos a pintar a luz e a paisagem tropicais com os mestres da Missão Artística Francesa" (Rocha, 2011, p.13). Disto decorria uma sensação de não estar de todo, pois a paisagem brasileira era revelada por uma técnica europeia. Luiz Felipe de Alencastro, em $O$ Trato dos Viventes, também faz referência à formação do Brasil como algo que ocorreu a partir de fora. "O Brasil se formou fora do Brasil" (Alencastro apud Rocha, 2011, p.11). A sensação de "não estar de todo" resulta do fato de que fomos constituídos no descentramento. 
O tema do "não estar de todo" tem uma vasta tradição no Brasil. Já havia aparecido na abertura de Raízes do Brasil, de Sérgio Buarque de Holanda ${ }^{6}$. A famosa passagem de "Raízes" - "somos ainda hoje uns desterrados em nossa terra" (Buarque de Holanda, 1995, p.31) - nos lembra que as formas de vida que trouxemos de países distantes se desenvolveram em um ambiente hostil. Roberto Schwarcz considera este trecho de Raízes revelador do fenômeno das "ideias fora de lugar" no Brasil, ou seja, a importação de estilos de vida e pensamento que não encontram espaço no território nacional.

Leyla Perrone Moisés destaca o sentimento do desterro entre os primeiros letrados da América Latina:

formados nas universidades das metrópoles, sentiam-se, em seus próprios países, como europeus exilados. (...) Os poetas brasileiros do século XVIII queixavam-se de nossos rios, à beira dos quais nenhuma ninfa resistiria ao calor e aos mosquitos (Perrone Moisés, 1997, p.3).

A colonialidade do saber decorre do fato de termos absorvido a cultura europeia acriticamente, de pretendermos ser um “Outro Ocidente” (Merquior, 1993), mais pobre, mais enigmático, mais problemático, mas não menos Ocidente. Esta colonialidade seria a responsável por nossa "inadequação" e sensação de "não estar completamente aqui".

Esta condição nos remete às noções de modelo e cópia (ver capítulo teórico). A ideia de "inadequação" só faz sentido se pensarmos que existe um modelo ao qual se adequar. Nesta interpretação, seríamos então uma cópia - de diferentes graus de qualidade conforme a época - de um modelo localizado na Europa.

Todavia, o descentramento não é uma característica exclusivamente brasileira. Segundo João Cezar de Castro Rocha, "não se trata de um fenômeno intrinsecamente brasileiro, mas da condição de países de passado colonial recente" (2011, p.13). Esta afirmação está inserida em toda uma tradição de considerar a América como extensão da Europa ${ }^{7}$.

Jorge Luis Borges costumava dizer que não há o especificamente latinoamericano. "Ser americano é um modo mais amplo de ser europeu, já que não

\footnotetext{
${ }^{6} \mathrm{Na}$ interpretação de Silviano Santiago, a ideia do desterro em Sérgio Buarque de Holanda será desbancada ao longo da narrativa por uma outra visão.

${ }^{7}$ Se a América é extensão da Europa, o Brasil será a extensão de Portugal. Evaldo Cabral de Melo lembra-nos que, desde o século XVI, a América portuguesa era considerada um "outro Portugal" (MELO, 2008, p. 19).
} 
somos outra coisa" (Borges, 1990, p. 18). Para Borges, a totalidade do mundo ocidental e uma boa parte do mundo oriental eram uma projeção da Europa. "Creio que nós somos o reflexo da Europa, a prolongamento da Europa, e que podemos ser um espelho, possivelmente magnífico, da Europa, posto que a Europa esquece geralmente que ela é Europa" (Borges, 1997, p.1).

A moléstia de Nabuco e a sensação de "não estar de todo" serão questionadas pelo movimento antropofágico no século XX, que chama a atenção para o caráter híbrido da cultura brasileira e latino-americana. Como veremos na discussão teórica (capítulo 3), o híbrido aqui não quer dizer necessariamente mistura, mas estar "entre-lugares", entre a Europa e a América.

Em outras palavras, a antropofagia parece ser o conceito central para entendermos como foi possível a constituição da América Latina e do Caribe como um “outro" da Europa, uma identidade em relação à qual a Europa podia constituir a si mesma. Isto significa introduzir a antropofagia na reflexão sobre relações internacionais em geral e na relação UE-América Latina em particular.

Os cronistas coloniais descreviam os atos dos ameríndios como antropofágicos e bárbaros. Desde a Grécia, a imagem da antropofagia era usada para representar a alteridade de forma pejorativa. "Classificar um povo como antropófago é marcá-lo com o signo mais radical da alteridade e da barbárie, como criaturas alienadas da razão e da sociedade civil, mais próximas das espécies canibais de animais do que da comunidade humana ética" (Greer, 2005, p. 279).

Heródoto considerava os antropófagos, que chamava de andrófagos, como os mais selvagens dos selvagens. "Não há homens que possuam hábitos mais selvagens do que os Andrófagos. Não conhecem nem a lei, nem a justiça, e são nômades. (...) De todos os povos de que acabo de falar são os únicos a comer carne humana" (Heródoto, 2001, 493). Já na Divina Comédia, o antropófago é submetido a um dos mais duros castigos ao ser enviado para a região mais longínqua do Inferno. É o que acontece com Ugolino, o nobre que teria devorado seus filhos no século XIII em Pisa. Em suma, a antropofagia é representada nesses relatos como o limite da humanidade, o ponto a partir do qual não podemos mais falar do humano.

Com a "descoberta" da América, o antropófago transforma-se no canibal. Segundo Enrique Dussel, a palavra canibal foi um dos primeiros neologismos criados pelo encontro entre europeus e americanos, revelando um mal-entendido. A 
nosso ver, o significante canibal, assim como a ideia de antropofagia, conservam um potencial epistêmico para se pensar as relações entre Europa e América Latina no século XXI.

Nesse sentido, a antropofagia e o canibalismo deixam de ser vistos como um costume bárbaro e passam a ser tratados como uma estratégia de relacionamento com a alteridade. Como aponta Jáuregui, "Na história cultural latinoamericana, o canibal tem a ver mais com o pensar e o imaginar do que com o comer" (2008, p. 16). Não se trata de negar a ocorrência histórica de casos de canibalismo $^{8}$. O que esses autores fazem é mudar o problema e a pergunta. Em vez de perguntar "comeu de fato ou não comeu?", passa-se a investigar os regimes de verdade das narrativas sobre o canibalismo, ou seja, a forma como o canibalismo é representado no discurso colonial.

Jáuregui chama a atenção para a presença do "tropo canibal" nas narrativas de viagem do século XVI e como o termo acaba se tornando o significante mestre para a diferença colonial. Luís Madureira desenvolve tese semelhante em Cannibal Modernities, ao repensar a "emergência da pós-colonialidade nos movimentos de vanguarda do Novo Mundo" (Madureira, 2011, p.300). Segundo este autor, a antropofagia prefigura o projeto pós-colonial de "provincializar o Ocidente" e se insurgir contra a hegemonia epistêmica dominante denunciada por Walter Mignolo. De acordo com Jorge Schwartz, o Manifesto Antropofágico representa "uma das estratégias mais originais elaboradas na América Latina para resistir aos inevitáveis processos de colonização" (SCHWARTZ apud Madureira, 2011, p.312).

A leitura de Madureira sobre o Manifesto é compartilhada por Vera Follain de Figueiredo, para quem a antropofagia representa uma narrativa contrahegemônica da modernidade. Segundo a tese de Mignolo, a ideia de modernidade foi construída a partir de um lugar hegemônico de produção do conhecimento. "Oswald reivindica o direito de dialogar com essa produção sem subserviência. (...) Busca outro lugar de enunciação que permita a relativização das imagens criadas pela tradição ocidental" (Figueiredo, 2011, p. 391).

A antropofagia funciona como uma estratégia que revela o lado obscuro da modernidade, ou melhor, sua outra metade, a colonialidade. Desta forma, o mani-

\footnotetext{
${ }^{8}$ Os relatos sobre a ocorrência de canibalismo são considerados pouco confiáveis. "Barlomeu de las Casas notou que, frequentemente, as notícias sobre canibais correspondiam a rumores e acusações e que as áreas em que habitualmente apareciam coincidiam com aquelas em que o encontro colonial enfrentava resistências" (JÁUREGUI, 2008, p. 21).
} 
festo de Oswald apresenta preocupações que serão posteriormente centrais para autores pós-colonialistas. O lado obscuro da modernidade é o lado violento, colonialista, eurocêntrico, desenvolvimentista ou "desenvolvimentalista", no neologismo de Dussel.

\subsection{5}

\section{Europa, Estados Unidos e América Latina-Caribe: aproximações e afastamentos}

A União Europeia e a América Latina e o Caribe não são entidades com identidades fixas, mas construções em processo contínuo de formação que surgem de discursos praticados ao longo dos séculos. Neste sentido, as lógicas da diferença e da equivalência são fundamentais para a compreensão da relação entre União Europeia, América Latina/Caribe e para a constituição de suas identidades. Num primeiro momento, a União Europeia tenta se diferenciar dos Estados Unidos no período pós-Guerra Fria apresentando-se como defensora dos direitos humanos, do multilateralismo, da lei internacional etc... É em relação ao "outro" norte-americano que os europeus tentaram, naquele período, construir uma identidade na política internacional.

Este empenho em se diferenciar dos Estados Unidos ganha novo impulso com a Guerra do Iraque, em 2003, quando se estabelece, após um breve apoio, o "hiato Atlântico" (Atlantic gap), conforme formulação do historiador Tony Judt. Naquele ano, o público europeu se opôs às linhas gerais da política externa do presidente americano George W. Bush.

Entretanto, como nos alerta Judt, o Atlantic gap não era apenas um desacordo sobre armas. "O que realmente estava afastando os dois continentes era o crescente desacordo sobre valores. Nas palavras do Le Monde, a 'comunidade transatlântica de valores está se deteriorando"” (Judt, 2005, p. 788). Em artigo assinado com Jacques Derrida em 2003, Jürgen Habermas discorre sobre os atributos da Europa que a distanciariam dos Estados Unidos, entre eles o secularismo e a condenação da pena de morte. Na avaliação de Judt, para observadores europeus, o uso da pena de morte parecia colocar os Estados Unidos em algum lugar fora da "civilização moderna". É interessante notar que, se no século XIX a civilização está associada ao cristianismo, no XXI ela aparecerá como o atributo daque- 
les que já se secularizaram. Ou seja, há um deslizamento do significante civilização ao longo de uma cadeia de significantes. Outro ponto da argumentação sugere que os Estados Unidos, por adotarem a pena de morte, não são suficientemente civilizados.

Como veremos no capítulo 4, os Estados Unidos constituíram a sua identidade justamente com base na dicotomia civilizado e bárbaro, na qual eles ocupavam a posição de civilizados, igualando-se aos europeus, enquanto os índios americanos eram representados como os bárbaros. Portanto, o manifesto de Habermas e Derrida rompe, de uma certa forma, com duas associações naturalizadas e estabelecidas: aquela entre civilização e cristianismo (já não é preciso ser cristão para ser civilizado na Europa) e aquela entre civilização e Estados Unidos.

Nesse contexto, as qualidades não-norte-americanas da Europa começaram a se tornar um elemento da auto-identificação europeia. Ser europeu passou a significar "não ser norte-americano". Ou seja, os valores europeus eram contrastados com os valores norte-americanos. Esta comparação está perpassada por um caráter normativo e etnocêntrico, pois ela permite que a Europa se apresente, no início do século XXI, como o modelo das virtudes internacionais, que deveriam ser imitadas pelos demais. Como vimos, esta representação parte do pressuposto de que os europeus teriam aprendido com seus próprios erros durante o século XX.

Não estamos seguros sobre esta suposição. A construção da imagem europeia como modelo das virtudes internacionais (o que poderíamos chamar de "arquivo europeu”) é resultado de um processo seletivo de memorialização, no qual alguns fatos do passado são esquecidos e outros lembrados. Apenas determinados elementos foram selecionados para fazer parte do "arquivo europeu". Nesse sentido, a construção da identidade europeia no período pós-Guerra Fria não deixa de ser uma "invenção do passado que serve ao presente" (Kohn, McBride, 2011, p. 14).

Conforme nos lembra Enzo Traverso, a história e a memória não são a mesma coisa. "A memória é uma representação do passado que se constroi no presente" (2011, p. 255). Obviamente, esse processo de reconstrução narrativa tem uma intenção fundacionalista, pois comporta uma tentativa de definir o que seria a essência europeia depositada no arquivo histórico. No entanto, as disputas que surgiram nos últimos anos sobre como a narrativa histórica europeia deve ser con- 
tada revelam o caráter contingente de seu fundamento ou a possibilidade de profanação do arquivo.

Tony Judt e Enzo Traverso, entre outros autores, destacam que as últimas décadas do século XX na Europa foram marcadas por um crescente fascínio público pelo passado como um "artefato desconectado, encapsulado não em memórias recentes, mas memórias perdidas" (Judt, 2005, p. 768). A história teria deixado de ser uma fonte de esclarecimento sobre o presente (a noção de Historia Magistra Vitae $^{9}$ ) para se tornar uma ilustração de como as coisas foram extremamente diferentes do que são hoje. A descontinuidade se sobrepõe à continuidade. Portanto, a narrativa histórica passou a enfatizar não o que unia os europeus ao passado, mas o que os separava desse passado.

É nesse contexto do final do século XX que a União Europeia tenta recriar para si uma identidade contrastante e independente da dos Estados Unidos. Durante a Guerra Fria, a Europa havia se tornado uma província dentro do "modelo de civilização transatlântico”. Segundo Hans-George Gadamer (1900-2002), de 1914 até o fim da Segunda Guerra Mundial, a Europa passou por um processo de "provincialização" ${ }^{\prime 10}$. Portanto, quando o modelo de civilização transatlântico é constituído nos pós guerra, a Europa que nele ingressa já é uma província, tendo deixado de lado a pretensão de governar o mundo em nome da razão universal.

A crise, como veremos com Laclau e Mouffe mais à frente, é o momento em que a contingência do fundamento é revelada e diversos projetos hegemônicos disputam a fixação do "significante vazio", tentando criar um ponto nodal (um fundamento), ainda que este também seja contingente.

O manifesto de Habermas e Derrida parece contestar a narrativa do descentramento ou provincialização da Europa ao afirmar que "a esfera pública europeia" estaria aberta a uma democracia cosmopolita. Segundo estes filósofos, a Europa teria de fazer referência ao seu glorioso passado (civilização, liberdade individual, direitos humanos, welfare state, ciência, filosofia). Nas palavras de Iris

\footnotetext{
${ }^{9}$ A expressão historia magistra vitae foi cunhada por Cícero e significa a história como mestra da vida ou a história como instrução para a vida.

${ }^{10}$ Boaventura de Souza Santos lembra que a provincialização da Europa é uma ideia de HansGeorge Gadamer recentemente popularizada por Dipesh Chakrabarty. A provincialização da Europa designaria o processo histórico da perda da centralidade cultural e política da Europa no sistema mundial moderno que teria se iniciado em 1914 e terminado com o fim da Segunda Guerra Mundial.
} 
Young, configura-se assim a proposta de um "recentramento" da Europa, exatamente o oposto de uma provincialização. Ao tentar construir sua identidade "em oposição aos Estados Unidos”, a União Europeia memorializa seu passado, selecionando os "aspectos supostamente gloriosos" para serem colocados no arquivo e silenciando sobre o colonialismo. Mais: os elementos selecionados são apresentados como parte de uma essência europeia, daí o caráter fundacionalista deste processo de memorialização.

Percebemos aqui a atuação da lógica da diferença no eixo do hemisfério norte na medida em que o discurso europeu tenta definir identidades essencializadas para a Europa (repositório de virtudes, secular, civilizada, respeitadora dos direitos humanos e da lei internacional) e para os Estados Unidos (religiosos, defensores da pena de morte, unilaterais).

Entretanto, a lógica da equivalência também atua simultaneamente neste eixo transatlântico, mostrando que a oposição entre essas duas "entidades" é apenas contingente. A oposição de identidades entre Europa e Estados Unidos se desfaz quando os dois são justapostos à América Latina e ao Caribe, pois, neste momento, a União Europeia e os Estados Unidos são reconfigurados como "equivalentes". Surge então o que Doty chamou de "ligação ocidental" (Western Bond). As diferenças entre União Europeia e Estados Unidos são superadas graças à existência desta "ligação ocidental", que, por sua vez, acentua as diferenças entre o Ocidente (UE e EUA) e o Não-Ocidente (América Latina/Caribe).

Vale notar que a atuação das lógicas da diferença e da equivalência no eixo Norte-Sul são a outra face da moeda da relação transatlântica. Quando a lógica da diferença atua entre Europa e Estados Unidos (Atlantic gap), a lógica da equivalência se dá entre a Europa e a América Latina e o Caribe. Ao contrário, quando a lógica da equivalência se estabelece entre Europa e Estados Unidos (Western Bond), a lógica da diferença preside a relação entre Europa e América Latina e Caribe.

\section{SITUAÇÃO 1:}

\section{Lógica da equivalência}

Europa- Estados Unidos
Lógica da diferença - $O$ outro

América Latina e Caribe 


\section{SITUAÇÃO 2:}

\section{Lógica da equivalência}

Europa-ALC

\section{Lógica da diferença - $O$ outro}

Estados Unidos

A América Latina e o Caribe, portanto, também têm suas identidades reconfiguradas pelo funcionamento simultâneo das lógicas da diferença e da equivalência. Na situação 1, a América Latina e o Caribe são representados como o Outro, o não-Ocidente, por oposição ao Western bond entre Europa e Estados Unidos. Como veremos no capítulo 4, o discurso europeu e o norte-americano se assemelham em sua caracterização do latino-americano e caribenho como pouco desenvolvido, imaturo, passional etc... No Western Bond da Comunidade Transatlântica, o etnocentrismo europeu se estende à América do Norte. Esta passa a ser uma extensão dos supostamente superiores valores europeus.

Na situação 2, temos a atuação de uma lógica da equivalência entre a Europa e a América Latina e o Caribe, a qual deve ser pensada a partir do contexto do Atlantic gap entre os Estados Unidos e a Europa. Como vimos, a Europa se apresenta no século XXI como portadora de valores morais que os Estados Unidos não mais possuiriam. Por outro lado, a Europa encontraria um "semelhante" na América Latina e no Caribe, regiões que compartilhariam dos valores europeus e poderiam ser definidas como um “Outro Ocidente”. Mas será que caberia falar de um European Union-Latin American Bond?

Poderíamos dizer que a construção da semelhança entre as duas regiões depende de um processo de memória seletiva por meio do qual a União Europeia elege a latinidade como representante dos valores comuns - e, portanto, da semelhança - entre a União Europeia e a América Latina e o Caribe. Só que esta memorialização de valores latinos é realizada ao custo do esquecimento de outras culturas, como as africanas e indígenas. Mais: referir-se à latinidade como algo consensual entre as regiões significa reproduzir o discurso monológico que apresenta os valores dos vencedores como naturais, apagando da memória a violência do processo de colonização por meio do qual aqueles mesmos valores puderam se tornar “consensuais". Quando a América Latina e o Caribe são designados como um “Outro Ocidente”, esta representação ocorre com base nos valores latinos em detrimento dos valores africanos, aymaras, tupis, quéchuas ... Temos, portanto, um 
silenciamento sobre a diferença colonial na construção/invenção desta comunidade União Europeia/América Latina/Caribe.

Na situação 1, a latinidade aparecia relacionada a pouco desenvolvimento, imaturidade e passionalidade, ou seja, tinha uma conotação negativa. Ela era contraposta aos valores anglo-saxões, supostamente melhores. No entanto, na situação 2, ela será associada aos valores europeus, agora considerados superiores aos norte-americanos, já que estes defendem a unilateralidade, a pena de morte, a força como meio de solução de controvérsias. Assim, no discurso europeu do século XXI, os valores europeus e a latinidade são o que sustenta as "virtudes internacionais", em oposição à "falta de civilização" dos norte-americanos.

Em suma, a lógica da diferença fixa identidades, estabelece oposições, enquanto a lógica da equivalência desfaz essas identidades fixas. Mas as duas lógicas agem simultaneamente, o que significa que a lógica da diferença voltará a fixar identidades, apesar do trabalho contrário e incessante da lógica da equivalência. O discurso tem, portanto, uma natureza dual. Ele contém, ao mesmo tempo, a possibilidade da fixação parcial de significado e a possibilidade da abertura. Em suma, a perspectiva pós-fundacional permite compreender que as relações entre a União Europeia, a América Latina e os Estados Unidos - as semelhanças e as diferenças entre elas - estão baseadas num fundamento contingente.

Vale destacar que, tanto na situação 1 quanto na 2, a América Latina e o Caribe aparecem como produtos da lógica da colonialidade (matriz colonial de poder) tal como teorizada por Walter Mignolo. A lógica da colonialidade opera em quatro domínios da experiência humana: econômico (apropriação de terra, exploração de mão-de-obra e controle das finanças), político, social e epistêmico. Não podemos nos esquecer da "cumplicidade cada vez mais estreita entre o cristianismo (e o saber cristão) e a evolução do capitalismo" (Mignolo, 2007, p. 54) na constituição da América. As bulas papais vinculavam a Igreja cristã ao mercantilismo e defendiam o direito dos cristãos de "tomar posse".

Ora a América Latina e o Caribe são representados como o "Outro" (o diferente, o não-ocidental) ora são vistos como o "Outro Ocidente" (semelhante, porém latino). No primeiro caso, não é difícil perceber como a representação da região como diferente e não-ocidental está intrinsecamente ligada à dimensão econômica, política e social da lógica da colonialidade. A América Latina e o Caribe são o espaço da apropriação econômica e da exploração da mão-de-obra. No 
segundo caso, a colonialidade do poder parece menos evidente, pois afinal há o reconhecimento de uma semelhança. Mas é justamente aí, na semelhança, que a colonialidade do poder se manifesta subrepticiamente. Falar em "Outro Ocidente" significa pressupor a Europa como modelo para a América. Nesta perspectiva eurocêntrica, a história da humanidade, como vimos em Dussel, é um processo linear no qual a Europa ocupa o estágio final da modernidade. Aqui, a América Latina e o Caribe não são apenas o "Outro", mas aquele que pode se tornar plenamente ocidental caso siga os modelos de desenvolvimento econômicos, políticos, sociais e epistêmicos europeus. No entanto, a diferença colonial está obscurecida nesta formulação.

A discussão acima mostra como as fronteiras entre Estados Unidos, União Europeia e América Latina-Caribe são o tempo todo repensadas em função das mudanças nas práticas discursivas e, consequentemente, nas identidades desses atores. O marco teórico pós-estruturalista permite problematizar essas fronteiras. No caso da aproximação entre União Europeia e América Latina/Caribe, a oposição aos Estados Unidos é reforçada. Neste caso, a linha fronteiriça inside/outside é traçada entre a associação estratégica UE-ALC (inside) e os Estados Unidos (outside).

Porém, concomitantemente a esse traçado fronteiriço, uma outra linha separa a União Europeia da América Latina/Caribe quando o discurso europeu interpreta a América Latina e o Caribe como o Outro bárbaro, o atrasado, o arcaico, o aprendiz. Neste discurso, a União Europeia é representada como o inside e a América Latina/Caribe como o outside. Neste deslocamento da fronteira, os Estados Unidos são vistos como semelhantes à Europa e incorporados ao inside. Europa e Estados Unidos se unem, portanto, no discurso sobre a América Latina/Caribe. Em outras palavras, o discurso europeu sobre o latino-americanocaribenho reproduz o discurso etnocêntrico norte-americano sobre a existência de uma outra América, latina, atrasada e pobre.

A partir do exposto, concluímos que a concepção moderna de fronteira como demarcação rígida entre inside/outside não dá conta da complexidade das relações entre a União Europeia e os seus outros. A produção de fronteiras é um processo ininterrupto e simultâneo, baseado num fundamento contingente. Segundo Laclau, o "outside constitutivo" tem uma função revelatória pois mostra a natureza contingente de toda objetividade. 
Em outras palavras, quando a União Europeia refere-se à América LatinaCaribe como região-irmã, os Estados Unidos aparecem como o Outro, o outside constitutivo. Ao contrário, quando o discurso europeu considera a América Latina como o outro bárbaro, esta passa a ser o outside constitutivo e os Estados Unidos se deslocam para o inside. As posições inside/outside, portanto, não estão dadas de uma vez por todas, não há um fundamento último que sirva de base para uma delimitação definitiva. O outside é, assim, o que revela a natureza contingente de uma objetividade, que pode ser a associação UE-ALC ou EUA-UE.

Nossa proposta de analisar os documentos das cúpulas entre União Europeia e América Latina-Caribe nos séculos XX e XXI incluirá a referência a práticas discursivas de outros períodos históricos, mas esta leitura não será realizada com base numa concepção de história linear, como se as relações entre União Europeia e América Latina e Caribe no século XXI fossem uma decorrência lógica das relações entre essas entidades em períodos anteriores. É por este motivo que as relações entre União Europeia e América Latina-Caribe não serão apresentadas numa sequencia temporal linear: séculos XVI, XVII, XVIII, XIX e XX. Ao contrário, nossa análise se concentra no presente, nas declarações de cúpula da última década, e apenas em momentos específicos remete a outros séculos. Como sugere Giorgio Agamben, é a partir da obscuridade do presente que conseguimos apreender o passado. Qualquer acusação de anacronismo seria despropositada, uma vez que só há anacronismo quando pressupomos uma história linear e sequencial, o que não é o caso no marco teórico pós-estruturalista.

\subsection{6}

\section{A China como o "outro oriental"}

A história da reconfiguração do sistema internacional que se iniciou nos anos 90 estaria incompleta se não destacássemos a ascensão da China. Se o período imediatamente posterior à dissolução da União Soviética pôde ser chamado de unipolar, o início do século XXI é marcado pela "ascensão do resto", nas palavras de Fareed Zakaria (2008), mas sobretudo da China. Segundo Timothy Garton Ash, a grande história deste século não será o combate ao terror desencadeado após o 11 de setembro, mas a ascensão da Ásia, além do deslocamento do poder do Ocidente para o Oriente. Garton Ash corrobora assim a tese já defendida por Mark 
Leonard de que a ascensão da China seria "a grande história de nossa época" (2008, p.5), algo equivalente à ascensão e queda de Roma, do Império Otomano, da Grã-Bretanha ou da União Soviética. Recentemente, Ian Morris destacou que a ascensão da China significa "a maior mudança em riqueza, poder e prestígio desde que a revolução industrial catapultou a Europa ocidental para o domínio global há 200 anos" (2010, p.1).

A China cresce mais de $9 \%$ ao ano há quase trinta anos, o que significa a taxa mais alta verificada historicamente para uma grande economia. Entretanto, diferentemente do "Outro americano", a China não compartilharia os "valores europeus", podendo ser assim denominada como um outro "radicalmente outro".

A constituição do americano como "Outro" se dá a partir da criação do Atlantic gap, quando os Estados Unidos supostamente teriam se afastado dos valores europeus que estiveram na base de sua formação. O Atlantic gap se configuraria, portanto, como uma degeneração da comunidade transatlântica. Ao contrário, o Outro "radicalmente outro" chinês esteve desde sempre no Oeste, uma região que não apresentaria o nível civilizatório da Europa ${ }^{11}$ por conta dos "valores asiáticos".

O debate sobre a existência de valores asiáticos em contraste com valores ocidentais intensificou-se nos anos 90 no meio político e acadêmico. Seus defensores pareciam retomar a teoria de Hegel sobre o pensamento asiático como destituído de logos e, portanto, pouco propenso à crítica e à liberdade tal como entendidas no Ocidente. $\mathrm{O}$ suposto despotismo inerente ao pensamento asiático teria sido responsável tanto pelo rápido crescimento quanto pela catástrofe econômica dos anos 90 nos países do Leste Asiático. De modo geral, os defensores dos "valores asiáticos" estavam se referindo ao Sudeste Asiático, sobretudo a Tailândia e Cingapura, mas era comum encontrar comentários de que o resto da Ásia era "similar".

Por outro lado, a preocupação com a ordem e a disciplina também estariam na base de uma concepção asiática sobre direitos humanos e democracia diferente daquela dos ocidentais. Há uma tendência nos Estados Unidos e na Europa a pres-

\footnotetext{
${ }^{11}$ Em sua Filosofia da História, Hegel afirma que a Ásia seria pré-filosófica. Para Hegel, a filosofia era uma herdeira direta do Logos grego, que estaria estreitamente vinculado à liberdade de pensar do espírito. Esta condição não existiria nas sociedades asiáticas, que, por isso, estariam fadados ao despotismo.
} 
supor que a liberdade e a democracia são uma antiga conquista da cultura ocidental ainda pouco disseminada na Ásia.

Esta tese foi criticada por muitos, entre eles o economista indiano Amartya Sen, para quem não há qualquer evidência de que valores asiáticos seriam essencialmente despóticos:

\begin{abstract}
Não há valores quintessenciais que separem os asiáticos como grupo de pessoas do resto do mundo e que estejam presentes em todas as partes desta imensa e heterogênea população. A tentação de ver a Ásia como uma única unidade revela uma perspectiva eurocêntrica (1997, p.3).
\end{abstract}

Em outras palavras, os chamados valores asiáticos invocados para justificar o autoritarismo não são especialmente asiáticos em qualquer sentido significativo. Eles também aparecem em escritos europeus dos últimos 2.500 anos. Não podemos esquecer que direitos políticos e civis ganharam uma forma particular no Ocidente num período relativamente recente, o que torna discutível a afirmação de que esses compromissos com a liberdade são um componente "tradicional" das culturas ocidentais. Ao analisar os trabalhos de intelectuais indianos, chineses e europeus, Sen mostra que as duas correntes de pensamento - a autoritária e a democrática - estiveram presentes na história asiática, assim como na história europeia. Portanto, poderíamos dizer que o debate em torno dos valores asiáticos em contraste com valores ocidentais está baseado numa seletividade da memória realizada pelo mundo ocidental. Extrai-se do passado os elementos que apontam na direção da liberdade e da democracia e "inventa-se uma tradição" (Hobsbawn, 1984).

O eurocentrismo também está presente na própria localização do Oriente. O termo, que durante muito tempo foi largamente usado para a Ásia, refere-se a uma posição da Europa centralizada no mapa mundi e voltada para o local de nascimento do sol. Mas o planeta não corresponde à representação de um mapa mun$d i$ aberto com a Europa e os Estados Unidos localizados no Ocidente. Se continuarmos em direção ao Oeste, descobriremos que o "Japão, a Coreia do Sul e Taiwan estão no ocidente da Califórnia" (Marquand, 2011, p.9).

Tanto na seletividade de elementos históricos quanto na construção da representação visual do Oriente, estamos diante do que Walter Mignolo denominou de colonialidade do saber, um conceito correlato ao de colonialidade do poder. A 
trama entre poder e saber, teorizada por Michel Foucault, reaparece assim nos discursos, relatos e narrativas do Ocidente sobre o Oriente no século XXI.

Em Identity and Violence, Sen nos apresenta um exemplo desta atuação da colonialidade do saber na sociedade ex-colonial. Ao associar a Índia com a espiritualidade e o imaterial, o discurso anti-colonial acaba reforçando o discurso colonialista que desqualifica as conquistas indianas na ciência e na matemática. O que vemos aqui é claramente uma identidade reativa indiana (espiritual, imaterial) que se contrapõe a uma identidade monolítica ocidental (racional, científica, material). Ou seja, os indianos reforçam a antinomia Ocidente-Oriente dos últimos 25 séculos segundo a qual o Ocidente é, por excelência, o lugar da razão, da eficiência, do Iluminismo, do moderno, do racional.

Marquand considera que a crise econômica de 2008 mostrou o absurdo desta proposição. "Pelo menos em termos de crescimento econômico, elemento privilegiado pelo modelo americano, podemos dizer que, na crise de 2008, a "Oriental" China e a Índia foram mais eficientes, mais bem-sucedidas e racionais do que os ocidentais Estados Unidos" (Marquand, 2001, p. 20). Enquanto os americanos gastaram descontrolada e irracionalmente, os chineses foram "racionais e disciplinados" o suficiente para pouparem.

Nos anos 90, a secretária de Estado de Bill Clinton, Madeleine Albright, afirmou que os Estados Unidos era a “nação indispensável”. Mas diante da crise e do endividamento dos Estados Unidos e da Europa, parece que o país indispensável ou, pelo menos, um dos indispensáveis, é agora a China. Em setembro de 2011, o governo chinês declarou que compraria títulos de dívida europeia e alertou os Estados Unidos para os seus gastos militares excessivos.

Neste sentido, a China vem se firmando como um "Outro" asiático tanto para os Estados Unidos quanto para a Europa. Em relação à China, podemos perceber o que Roxanne Lynn Doty chamou de western bond (ligação ocidental) entre Europa e Estados Unidos. Quaisquer desavenças na comunidade transatlântica são atenuadas e silenciadas diante de um terceiro que atua como "Outro". Neste momento, os valores europeus e norte-americanos parecem encontrar uma harmonia sob a denominação mais genérica de "valores ocidentais", os quais se contraporiam a supostos "valores asiáticos".

O discurso europeu sobre os valores asiáticos, que criaria uma oposição entre o Ocidente e o Oriente, entre racionalidade e irracionalidade, entre o europeu 
e o asiático encontra sua versão norte-americana no discurso contemporâneo sobre a China "como uma ameaça" ao equilíbrio das contas americanas e à hegemonia ocidental liberal. Em 2007, o departamento de pesquisas do Congresso americano elaborou um relatório intitulado Is China a Threat to the US Economy?. Embora reconheça que a compra do governo chinês de bônus do Tesouro americano tem financiado o décifit federal e ajudado a manter as taxas de juros dos Estados Unidos relativamente baixas, o relatório aponta para a ameaça chinesa. O décifit comercial com a China é visto como resultado de "práticas de comércio injustas, como a moeda artificialmente subvalorizada e os subsídios para produtores domésticos" (2007, p. 1). Ou seja, o chinês é representado como trapaceiro, nãoconfiável, desonesto, manipulador das regras de comércio. Além disso, a China “crescentemente ignora normas antigas" (Samuelson, 2008, p. 1) de comércio e promove "uma política de comércio predatória" (loc. cit). O discurso europeu sobre os valores asiáticos como intrinsecamente autoritários é reproduzido em versão norte-americana, que destaca o caráter antiliberal do governo chinês, supostamente contrário às "antigas" regras do livre-comércio. O suposto autoritarismo da China é assim visto como uma ameaça à ordem liberal criada pelos Estados Unidos após a Segunda Guerra Mundial.

O discurso sobre uma China detentora de valores diferentes dos ocidentais pode ainda estimular teorias como a de Vicente Palacio sobre uma possível associação entre a Europa, os Estados Unidos e a América Latina. Estes três continentes estariam ligados por valores ocidentais, que se oporiam aos valores asiáticos da China. Esta funcionaria, portanto, como um "Outro" contra o qual poderia ser construído um "Novo Ocidente” (Palacio, 2011, p. 273).

\footnotetext{
A região que abarca as Américas e a Europa compartilha não apenas uma herança comum - história, valores e instituições -, mas também os elementos sobre os quais podemos construir uma comunidade transatlântica alargada: comércio, investimento, imigração e trocas culturais e sociais dinâmicas (Palacio, 2011, p. 274).
} 


\section{4}

\section{A Crise Europeia e o fim do modelo}

Com a crise econômica na Europa, uma das questões que se tornou pertinente foi justamente a de se o continente estaria novamente se tornando irrelevante. Será que a crise europeia não está mostrando exatamente a falta de vitalidade espiritual da Europa? Não estariam os líderes europeus falhando em termos de vitalidade espiritual? Depois da crise econômica, como podemos continuar a falar da Ideia de Europa como um ideal ou um modelo para a América Latina e o Caribe?

A crise econômica iniciada em 2008 nos Estados Unidos expandiu-se e aprofundou-se a partir de 2010 na Europa. Depois de alguma melhoria em 2011, vários países da zona do euro voltaram a apresentar problemas de financiamento de suas dívidas no final daquele ano e em 2012. Algumas explicações para a crise europeia apontam a arquitetura institucional incompleta da zona do euro como a causa do problema. Seria necessário criar um organismo financeiro supranacional, aprofundando a integração com uma união fiscal. Outras localizam o problema no chamado modelo social europeu, que se traduziria na manutenção de um Estado de Bem-estar social. Nestes discursos, a União Europeia não poderia mais ser vista como um modelo de bem-estar e de integração bem sucedida, nem para a América Latina nem para qualquer outra região do mundo.

O que se depreende destas análises muitas vezes é uma descrença na capacidade da Europa de buscar seu caminho para o "progresso" e o "desenvolvimento" no mundo globalizado. Estaria em questão, portanto, muito mais do que a precariedade do projeto de construção do euro ou a falência do Estado de bem-estar social. A Europa poderia estar perdendo novamente sua relevância, após um período pós-Guerra Fria em que a possibilidade de sua recentralização apareceu como uma meta plausível. A Ideia de Europa, ou seja, de uma civilização capaz de oferecer bem-estar à sua própria população e ainda exportar esse modelo para o mundo, vem sofrendo um desgaste por conta da crise do euro.

É preciso, todavia, estar atento para o que está em jogo quando se diz que o modelo europeu está obsoleto. Para os que defendem a austeridade fiscal proposta por Angela Merkel, o modelo do Estado Providência é o responsável pelo endividamento de alguns países e, por isso, deveria ser descartado. Seria este o 
modelo por trás da paralisia e da falta de competitividade europeia num mundo globalizado. Por outro lado, os críticos das políticas de austeridade adotadas na Europa chamam a atenção para o fato de que são justamente essas políticas que estão transformando a Europa num não-modelo para a América Latina e para o mundo.

A partir de nossa discussão na seção anterior, poderíamos questionar se a atual crise econômica - e, sobretudo, a resposta dada a ela até o momento - não mina também o projeto europeu de construção de uma nova ordem internacional capaz de fazer face àquela erigida pelos Estados Unidos nos anos 90. A tentativa de se contrapor aos Estados Unidos pela defesa dos direitos humanos, respeito à lei internacional e de uma globalização mais humana não pode ser sustentada quando, diante da crise econômica, a Europa corta salários e gastos em áreas essenciais ao bem estar da população e intensifica as políticas de restrição à entrada de migrantes.

Como a diferenciação da Europa em relação aos Estados Unidos se dá a partir de um processo de construção da semelhança com a América Latina, no momento em que a Europa não mais se opõe aos Estados Unidos, ela concomitantemente se afasta da América Latina. Isto se torna mais evidente no caso das migrações, uma vez que o aumento do controle na fronteira atinge latino-americanos, rompendo com qualquer discurso sobre uma possível semelhança entre latinoamericanos e europeus.

Para Abraham Newman, a Europa está implementando políticas de austeridade que deixariam o Tea Party, ala ultraliberal do Partido Republicano, com inveja. Na cúpula da União Europeia marcada para 28 e 29 de junho, um tratado sobre pacto fiscal foi apresentado como solução para a crise europeia. $\mathrm{O}$ "Tratado da austeridade", na expressão de Newman, cria sanções para os países que não seguirem os critérios estabelecidos pelo Tratado de Maastricht, em 1992.

A austeridade vai transformar a economia política da Europa no longo prazo, dando credibilidade a ideia neoliberais de governo limitado e mercados pouco regulados. A ironia dessa transformação é que ela revigora exatamente as ideias que ajudaram a causar a crise (Newman, 2012, p.1).

Nesse contexto, a Grécia se tornou o laboratório do movimento de austeridade. Os gregos são vistos como os maus alunos que não souberam aplicar corre- 
tamente a ajuda concedida pela União Europeia desde a entrada do país na zona do euro. Desta forma, cria-se uma oposição hierárquica entre os europeus do norte, disciplinados com as contas, e os do sul, perdulários que se aproveitaram das vantagens de entrar na zona do euro. A oposição hierárquica que aparece, em alguns momentos, (como veremos ao longo da tese) entre europeus e latinoamericanos sofre aqui um deslocamento com a crise do euro, transformando-se em oposição entre europeus do norte e europeus do sul. Este deslocamento ocorre por meio da construção de uma similaridade entre europeus do sul (os "latinos" da Europa) e latino-americanos.

As comparações entre a Grécia e a Argentina de 2001-2002 são abundantes na imprensa internacional. O jornalista Larry Elliott, do The Observer, acredita que a Grécia deveria seguir o exemplo da Argentina de desvalorização da moeda. No entanto, a Grécia só teria autonomia para isto se deixasse a zona do euro. Para Elliott, a Argentina escolheu um caminho solitário em 2002 e a previsão era de um “Armageddon econômico”. No entanto, o país cresceu 9\% de 2003 a 2007. Já o ex-diretor do Banco Central argentino Mario Blejer entende que a Grécia não deve seguir o exemplo argentino, pois, o custo do fim da paridade entre o peso e dólar foi alto para a Argentina. Segundo Blejer, houve recuperação e crescimento após a desvalorização argentina, mas disso não se segue que o modelo argentino seja bom para a Grécia. Afinal, diz ele, este país faz parte de uma estrutura monetária multilateral, o que não acontecia no caso da Argentina.

Apesar de os dois exemplos acima se limitarem a fazer uma comparação da situação financeira da Grécia de 2012 e da Argentina de 2002, o debate sobre a crise europeia também tem resvalado para explicações culturais para o endividamento grego. E é justamente neste ponto que características atribuídas aos latinoamericanos nos anos 90 voltam a ser utilizadas para se referir aos gregos, como, por exemplo, a preguiça. Seriam os gregos preguiçosos como os latinoamericanos? Dizer para os gregos não seguirem o exemplo argentino não seria uma forma discreta de alertá-los para as consequências da falta de disciplina com as finanças? A indisciplina dos argentinos ao decidirem pela moratória não deveria ser copiada pelos gregos, parecem dizer alguns críticos. O perdulário também é frequentemente associado à irracionalidade e a um comportamento impulsivo. Ao contrário dos europeus do norte, os europeus do sul e os latino-americanos seriam menos racionais, mais emotivos e, portanto, mais propensos a gastar do que a 
poupar. A falta de disciplina fiscal seria apenas uma consequência da falta de disciplina moral.

Com esta estratégia de limitar o "problema" a uma determinada parte de seu território, "o sul", a União Europeia pode continuar a utilizar o seu discurso sobre um modelo europeu de austeridade a ser seguido e aplicado pelos países não tão disciplinados. A Grécia torna-se alvo de programas do Fundo Monetário Internacional antes destinados aos chamados "países em desenvolvimento". Os analistas se preocupam em mostrar que a Grécia atual em nada lembra a Grécia do século V a.c., berço, segundo estas interpretações, da cultura europeia (ver Dussel, capítulo 3). A Grécia do século XXI é colocada ao lado de Portugal, Espanha e Itália, países que não "carregam o desenvolvimento em seu núcleo", conforme acreditava Hegel.

Portugal, Espanha, Itália e Grécia frequentemente aparecem em charges e textos como países que não conseguem ter o mesmo nível de produtividade, disciplina e responsabilidade que os demais. Em artigo publicado no "The Guardian", o editor do jornal grego Kathimerini disse que a Grécia deveria escolher entre "se tornar a versão europeia da Argentina ou amadurecer em direção a um Estado europeu moderno" (Papahelas, 2010, p.1). Em suma, os países latino-americanos continuam a ser vistos como imaturos, agora acompanhados pelos países do Sul da Europa, que teriam de optar entre ser latino-americanos imaturos ou europeus maduros. Ironicamente, os gregos se transformam nos novos bárbaros da Europa.

Para Ulrich Beck, pretende-se "civilizar o Sul irresponsável e endividado em nome de princípios universais, ou seja, em nome do 'bom senso econômico', do "bem da Europa"' (2012, p.3). Os princípios universais a que Beck se refere seriam princípios alemães. Uma espécie de universalismo alemão estaria sendo hoje apresentado como universalismo europeu para os países do Sul. De acordo com o discurso do universalismo alemão, seguir as regras alemãs significaria optar pelo euro e pela permanência na Europa.

Dado que a Europa não tem como sustentar um projeto alternativo de ordem internacional e globalização, haveria ainda interesse em manter seu comprometimento com a associação estratégica? Antes de qualquer consideração sobre uma fissura na associação estratégica UE-ALC, devemos lembrar que a crise econômica europeia provocou uma divisão dentro do próprio bloco europeu. O tratamento dispensado até o momento aos países endividados da UE mostra uma "co- 
munidade imaginada" em frangalhos. De certa forma, esta fratura também leva a um enfraquecimento da "comunidade imaginada" da associação estratégica UEALC.

Entre a Europa do Norte e a do Sul estabelece-se uma fronteira que situa o Sul da Europa ao lado de países da América Latina. É como se a oposição hierárquica Europa/América Latina se transformasse na oposição Europa do Norte/Europa do Sul-América Latina. Em outras palavras, o distanciamento da Europa em relação à América Latina começa a ser desenhado dentro da União Europeia, no momento em que o bloco se refere a seus países periférios com os mesmos termos pejorativos outrora empregados para designar o latino-americano como um “outro bárbaro". Existe uma "outra Europa”, representada por Grécia, Portugal, Espanha e Itália, que, por sua vez, tem comportamento semelhante aos "outros latino-americanos": emotividade, impulsividade, irracionalidade e falta de disciplina. Em meio à crise, a estratégia discursiva da União Europeia retoma o discurso de um afastamento entre o europeu e o ibérico/latino-americano. Os territóriosponte - Espanha e Portugal - , que faziam a ligação da Europa com a América Latina, se transformam em muralhas que dificultam a comunicação entre essas duas regiões. 


\section{Desconstruindo e Descolonizando}

Não é comum encontrar estudos sobre as relações entre a União Europeia e a América Latina que utilizem um marco teórico pós-positivista. O contrário também é verdadeiro. Aqueles que trabalham na perspectiva pós-positivista geralmente não se voltam para as relações entre estas duas regiões.

Embora tenhamos apontado algumas insuficiências das abordagens tradicionais na seção 2.1 do capítulo 2, não pretendemos negar sua validade. A escolha por um marco teórico pós-positivista decorre de nossa percepção de que a dimensão discursiva e representacional é comumente negligenciada nos estudos sobre a Europa e a América Latina.

Ao se referir às relações entre a União Europeia e a América Latina e o Caribe, as abordagens tradicionais presumem a existência a priori de um Norte (a União Europeia) e um Sul (a América Latina e o Caribe) que seriam entidades não-problemáticas capazes de interagir uma com a outra em determinados períodos. A própria expressão "descoberta da América" parte do pressuposto da existência a priori de algo que foi simplesmente descoberto por um sujeito europeu, também pré-existente.

De acordo com estas abordagens tradicionais, as declarações de Cúpula entre a União Europeia e a América Latina e o Caribe, que serão analisadas nos próximos capítulos desta tese (capítulo 4 e capítulo 5), representariam, portanto, mais uma etapa dessa relação entre duas entidades constituídas a priori.

Ao contrário, a partir de um marco teórico pós-estruturalista, é possível afirmar que foram os "encontros" ou as "relações" entre a Europa e a América Latina e o Caribe que forneceram tanto as práticas discursivas quanto o contexto no qual as identidades dessas regiões puderam ser construídas, tanto no século XVI quanto no século XXI.

A partir de 1999, com as reuniões de Cúpula, detectamos o surgimento de um novo sujeito a partir dos "encontros" UE-ALC: a associação estratégica birregional. O discurso presente nas declarações funda um espaço birregional (a Co- 
munidade União Europeia-América Latina-Caribe), pretendendo conferir-lhe legitimidade, autoridade e poder de agência no sistema internacional.

A associação estratégica é ainda um campo de forças cujos significados podem ser contestados e que contém em si um espaço de abertura. Em outras palavras, as identidades da União Europeia e da América Latina e do Caribe não estão dadas de uma vez por todas dentro da associação estratégica, mas continuam sujeitas a um processo de transformação. A teoria de Chantal Mouffe e Ernesto Laclau nos possibilita avaliar como a "associação estratégica" funciona como um "significante vazio ou flutuante" 12 , gerando uma disputa ininterrupta entre grupos que tentam fixar seu significado. A ambiguidade e falta de precisão do termo "associação estratégica" permite que a União Europeia fixe seu significado ad hoc, conforme sua necessidade de aproximação ou afastamento da América Latina e do Caribe. Por outro lado, o significante flutuante da "associação estratégica" também permite que América Latina e o Caribe tentem fixar seu significado de acordo com seus interesses.

A fim de compreender melhor a associação estratégica iniciada em 1999, esta pesquisa pretende realizar uma genealogia crítica das relações União Europeia-América Latina-Caribe, investigando como determinadas práticas representacionais - como as oposições hierárquicas entre as duas regiões - persistem ao longo dos séculos. A genealogia também nos permite perceber que não há identidades fixas e naturalizadas para a União Europeia e a América Latina e o Caribe; estas foram - e continuam - sendo construídas historicamente nos vários "encontros".

Na perspectiva teórica que escolhemos, a articulação não é apenas uma prática que será estudada pelo pesquisador, senão que constitui também uma prática do próprio pesquisador, que pode recorrer a diferentes autores contanto que apresente as semelhanças entre eles e as premissas ontológicas do marco teórico. Para tanto, utilizaremos as obras de Michel Foucault (a fase arqueológica e a genealógica, considerando que não há uma separação rígida entre elas), Mikhail Bakhtin e Jacques Derrida, assim como as contribuições de Ernesto Laclau e Chantal Mouffe, que, por sua vez, recorrem a Foucault e Derrida. No entanto, como veremos neste capítulo, o pós-estruturalismo deve ser complementado - po-

\footnotetext{
${ }^{12}$ Este conceito de Laclau e Mouffe será discutido mais à frente neste capítulo.
} 
rém não negado - por uma abordagem descolonizadora capaz de destituí-lo de sua origem etnocêntrica. Com este objetivo, veremos como as obras de Walter Mignolo, Aníbal Quijano, Enrique Dussel, Arturo Escobar e Fernando Coronil nos permitem uma leitura crítica do pós-estruturalismo e, consequentemente, uma reflexão sobre como desconstruir a partir da periferia do sistema, revelando a diferença colonial.

Por fim, devemos dizer que não pretendemos adotar uma abordagem estritamente textualista - que pressuporia uma demarcação nítida entre texto e contexto. Pretendemos pensar o contexto histórico em que se dão as práticas discursivas de constituição das identidades.

Antes de discutirmos as relações entre os autores, no entanto, convém apresentar as linhas gerais do marco teórico selecionado, com suas potencialidades e limitações.

\section{1}

\section{O marco teórico pós-estruturalista e pós-fundacionalista}

A teoria e a análise de discurso pós-estrututralista está relacionada à Escola de Teoria do Discurso de Essex, na qual a obra de Ernesto Laclau ocupa uma posição importante. Em colaboração com Chantal Mouffe, Laclau fez uma crítica ao essencialismo e determinismo da Teoria Marxista no livro "Hegemonia e Estratégia Socialista”, enfatizando a contingência e a historicidade do que chamamos de objetividade. O foco se desloca para a problematização das representações e categorizações do mundo que possuem um caráter hegemônico. O objetivo da análise do discurso, na perspectiva da Escola de Essex, é mapear os processos pelos quais o significado é criado e fixado, e como algumas fixações se tornam institucionalizadas e hegemônicas.

A perspectiva pós-estruturalista parte do pressuposto de que as identidades de sujeitos e objetos materiais são constituídas como tais no discurso, o que não significa negar o mundo material. Reproduzimos aqui a tão citada argumentação de Laclau e Mouffe sobre este ponto:

O fato de que todo objeto é constituído como um objeto de discurso não tem nada a ver com o fato de haver um mundo externo ao pensamento ou com uma oposi- 
ção entre realismo e idealismo. O que se nega não é que os objetos existam fora do pensamento; o que se nega é que os objetos possam se constituir enquanto tais fora de qualquer condição discursiva (1985, p. 108).

A identidade não deve ser vista como um epifenômeno de uma subestrutura material mais substantiva. Isto seria repetir a lógica de uma divisão entre superestrutura e infra-estrutura. Disto decorre que não podemos traçar uma separação nítida entre práticas discursivas, puramente lingüísticas, e não-discursivas, pois recairíamos na dicotomia entre pensamento e realidade. Por esta razão, diz Laclau, a metonímia e a metáfora não são formas de pensamento que acrescentam um segundo sentido (a conotação) à realidade; ao contrário, essas figuras de linguagem são parte do terreno primário no qual o social é constituído. Existe um entrelaçamento do literal e do figurativo. Como veremos mais à frente, a própria noção de hegemonia não deixa de ser uma metonímia, na medida em que temos uma parte (os interesses de um grupo particular) que pretende se apresentar como a legítima representante do todo (os interesses de todos, portanto universais). A metáfora também é utilizada para hegemonizar o discurso como, por exemplo, a paradiástole, que realiza uma redescrição de algumas características, chamando o astucioso de sábio, o temerário de corajoso, o avarento de cauteloso.

A definição de discurso em Laclau é tão ampla que inclui o que seria comumente chamado de não-discursivo. O discurso "não está restrito à fala ou à escrita, mas engloba todos os sistemas de significação. Neste sentido, ele é contíguo com a vida social" (Laclau, 2006, p. 106). Ao adotarmos a teoria de Laclau e Mouffe nesta pesquisa, estamos assumindo o caráter material e performativo do discurso e da identidade.

É importante destacar que a abordagem pós-positivista não nos fornece um conjunto de métodos para conduzir uma pesquisa concreta. O método não é compreendido como um grupo de regras e técnicas supostamente neutros e mecanicamente aplicáveis a todos os objetos empíricos. Ao contrário, quando optamos pela análise pós-estruturalista do discurso, as questões de metodologia aparecem sempre relacionadas a premissas ontológicas e epistemológicas incompatíveis com a perspectiva positivista das teorias essencialistas sobre a produção do conhecimento. A premissa ontológica, como veremos neste capítulo, está relacionada à ausência de um fundamento último para a verdade. Disto decorre que a epistemologia 
adotada não pode ter como objetivo a busca por uma verdade ou fundamento último.

Em relação a este ponto, vale lembrar a presença e a influência de Immanuel Kant na obra de Michel Foucault e do marco teórico pós-estruturalista. Segundo Kraemer, A Crítica da Razão Pura apresenta uma série de questionamentos sobre o conhecimento que estará na base das concepções epistemológicas pósestruturalistas. A Crítica, por exemplo, realiza um deslocamento da pergunta sobre o conhecimento. Não se trata de saber algo sobre o ser das coisas, mas sobre as condições de possibilidade da ciência. Além disso, a Crítica não pergunta sobre os fundamentos ideais ou metafísicos do conhecimento, mas se contenta em saber quais são os elementos que o constituem enquanto fato.

Kraemer lembra que a questão do fundamento já havia sido deslocada por Leibiniz nos séculos XVII e XVIII com a introdução do princípio da razão suficiente, que contraria a tese clássica sobre o fundamento. Em Aristóteles, o fundamento significava a causa incondicionada, da qual dependeriam as demais causas condicionadas. O fundamento era a condição de possibilidade última, a causa essenacial. O princípio de razão suficiente elimina a noção de causa incondicionada e essencial e propõe em seu lugar uma "causa suficiente e necessária". A teoria de Leibiniz traz uma vantagem para a ciência, na medida em que esta não precisa mais "se perder" na busca dos fundamentos últimos; não há mais necessidade de ir tão longe. Por outro lado, essa suposta "vantagem" significa restringir o pensamento aos aspectos lógicos ou aos fenômenos, sem mais indagar sobre as condições de possibilidade. Outro problema da razão suficiente diz respeito à noção de necessidade, que pode facilmente nos levar para o caminho dogmático no qual conceitos históricos e subjetivos e, portanto, contingentes, são elevados à condição de fundamento último. Em suma, Leibniz elimina a causa fundamental, mas dá à razão suficiente o mesmo caráter de necessidade que a causa fundamental possuía.

Assim, diz Kraemer, o projeto kantiano reintroduz a crítica ao fundamento, diferenciando entre fenômeno e numenon. A causalidade como necessidade investiga a natureza enquanto fenômeno (acontecimento observável). No entanto, Kant não advoga nenhum fundamento (metafísico) para o conhecimento e tampouco um discurso sobre as origens. Não é possível um conhecimento do em-si (numenon), de uma realidade em-si. O que podemos conhecer são apenas os fe- 
nômenos, que observamos por meio de nossos esquemas mentais. Ou seja, podemos fazer um uso legítimo da razão para os fenômenos, mas não para o numenon, que é incognoscível.

Na filosofia kantiana existe a pressuposição de que o mundo possui uma essência, uma substância, um fundamento, a coisa-em-si; só não podemos conhecê-la. No reconhecimento da existência da coisa-em-si e, portanto, de uma ontologia metafísica, Kant não difere muito da tradição filosófica. Será apenas no questionamento sobre o conhecimento que Kant abrirá novas possibilidades epistemológicas para a filosofia nos séculos XIX e XX.

Tendo em vista esta abordagem sobre o conhecimento, optamos por "problematizar" as relações entre a União Europeia e a América Latina e o Caribe em vez de adotar um método destinado a descobrir ou medir uma "verdade" sobre um objeto. A problematização, tal como elaborada por Michel Foucault, propõe a construção do objeto de pesquisa assim como a pergunta de pesquisa, levando em consideração elementos arqueológicos e genealógicos (questão que será discutida mais à frente). Em nossa pesquisa, a problematização aponta para o discurso paradoxal utilizado pelas duas regiões quando se referem uma à outra ao longo dos séculos: ora vemos similaridade, ora dissimilaridade. Esta abordagem arqueológica é complementada pela genealógica na medida em que a análise do discurso que será empreendida concentra-se em "discursos presentes" - mais especificamente, os discursos das cúpulas entre a União Europeia e a América Latina e o Caribe ocorridos entre 1999 e 2010 -, que serão examinados à luz de outros exemplos históricos.

Consequentemente, nossa hipótese não pode ser algo passível de ser aprovado ou rejeitado ao final da pesquisa, como se estivéssemos tentando descobrir o que o empírico tem a nos dizer sobre nossa elaboração teórica. Na perspectiva pós-estruturalista, a hipótese deriva da problematização. No caso de nossa pesquisa, a problematização das relações União Europeia-América Latina nos permite levantar a hipótese de que existe uma permanência de determinadas representações entre ambas as regiões ao longo dos séculos.

Um ponto em comum entre os autores mencionados na introdução deste capítulo diz respeito ao caráter aberto e incompleto do discurso. Em suas margens, o discurso se encontra com outros discursos que também são abertos e instáveis. $\mathrm{Na}$ linguagem foucaultiana, as "formações discursivas" não estão isoladas do 
mundo exterior por uma fronteira, mas se conectam com outras formações discursivas também em processo de transformação.

O termo "formação discursiva" aparece nos escritos da fase arqueológica de Foucault, considerada pelos críticos como distinta da fase genealógica e demasiado estruturalista. No entanto, como ressalta Inês Lacerda Araújo, "não há um corte radical entre a arqueologia e a genealogia (...) pois a descrição das práticas discursivas é que fornece o material para a genealogia" (2007, p. 1). Além disso, o suposto estruturalismo da formação discursiva é desmentido pela ideia foucaultiana de "irrupção dos acontecimentos", que afasta a possibilidade de uma continuidade e uma totalidade histórica inerente às grandes estruturas.

Ao recorrerem ao conceito de formação discursiva, Laclau e Mouffe enfatizaram o aspecto da "irrupção dos acontecimentos" e sua contribuição para a abertura do discurso. Para estes autores, a ordem social não é uma essência; ao contrário, ela se caracteriza por práticas de articulação que se expressam em "cadeias de significantes" mais ou menos precárias. A instabilidade na cadeia de significantes ocorre devido à existência de um significante vazio ou flutuante. Os grupos de uma ordem social disputam a apropriação do "significante vazio", tentando preenchê-lo com práticas de articulação ligadas a seus próprios projetos hegemônicos. Assim, há uma proliferação de significados na ordem social que só é limitada quando um grupo consegue preencher o "significante vazio ou flutuante", fixando parcialmente o significado em "pontos nodais". Neste momento, a cadeia de significantes se estabiliza, ainda que provisoriamente.

Ora, é justamente o caráter parcial da fixação que garante a possibilidade de uma abertura no discurso em alguns momentos, sobretudo em épocas de crise. Em outras palavras, as "formações discursivas" de cada grupo social estão constantemente em disputa para se tornarem hegemônicas por meio da fixação de um "ponto nodal". Mas o caráter inerentemente precário do ponto nodal, que pode ter uma duração curta ou longa, transforma a formação discursiva num espaço propício à "irrupção do acontecimento" (Foucault) ou a uma abertura.

Laclau e Mouffe irão se referir à irrupção como um momento de crise hegemônica no qual o quadro de inteligibilidade que até então fazia sentido numa determinada ordem social é abalado. Desta forma, a cadeia de significantes da prática articulatória hegemônica ou da formação discursiva é desestabilizada. É neste momento que o ponto nodal se torna mais "frouxo", abrindo a possibilidade 
para que o significado parcialmente fixado pelo grupo hegemônico seja desestabilizado e o significante vazio volte a ser alvo de disputa. O momento da disputa é também aquele em que a dimensão hegemônica da política se torna mais intensa.

Um exemplo apontado por Laclau seria o do significante democracia, que adquire significados diferentes conforme seja articulado com os termos "antifascismo" ou "anticomunismo" numa cadeia de significantes. Uma articulação mais recente tem sido aquela entre democracia e mercado capitalista, em uma formação discursiva que é apontada por muitos como neoliberal. No entanto, Fernando Coronil chama a atenção para a articulação do significante democracia com socialismo nos governos da esquerda latino-americanos das duas últimas décadas.

Em Debates e combates, posterior a Hegemonia e Estratégia Socialista, Laclau refere-se à relação entre a dimensão do vazio e a constituição das identidades. Estas só podem vir a se formar porque há um espaço vazio no qual ocorrem determinadas práticas articulatórias. Laclau chama a atenção para um "processo recíproco" que estrutura todo campo político discursivo. Por um lado, a dimensão do vazio debilita o "particularismo de um significante concreto" (Laclau, 2008, p. 15), ou seja, não há particularismo completamente estável dada a permanência do vazio e, consequentemente, sempre existe a possibilidade de abertura. Por outro lado, a particularidade confere à universalidade um corpo, uma encarnação, algo de concretude. A hegemonia (ou, como vimos acima, a prática articulatória hegemônica) se estabelece quando uma certa particularidade passa a ser tomada como universalidade. Como veremos ao longo desta tese, o particularismo europeu se apresentou como universal em diferentes períodos históricos.

Qualquer contestação a uma prática articulatória hegemônica também tentará associar um particularismo ao universalismo, criando uma nova relação hegemônica. A encarnação (do universal no particular) é inerente a todo tipo de relação hegemônica. No entanto, a encarnação não deve ser confundida com reificação, pois esta “consiste numa operação de inversão. O que é derivativo aparece como originário; o que é aparente é apresentado como essencial" (Laclau, 2008, p. 19).

Pensar a encarnação como reificação seria acreditar que o grupo hegemônico A estabelece sua hegemonia com base num fundamento último. E que um grupo hegemônico não-A contestaria a hegemonia de A também com base num fundamento último. Esta seria a fórmula A-não A do conflito, rejeitada por Laclau 
na medida em que a identidade de cada pólo se limita a ser a negação do outro. Nesta abordagem, o campo político abarcaria dois essencialismos (dois fundacionalismos) em contraposição. Por exemplo, o projeto hegemônico europeu de uma missão civilizatória (baseado numa essência europeia e identidade europeia) seria contestado por um projeto hegemônico anticolonial (que se apoiaria numa essencialização do passado histórico pré-colonial e numa identidade étnico-cultural).

Ao contrário, Laclau entende que a encarnação do universal no particular não tem relação com a ideia de um fundamento último. A encarnação estabelece um "fundamento contingente", segundo a expressão de Judith Butler. Esse fundamento contingente seria formado pela "agregação contingente de elementos heterogêneos" num ponto nodal. Desta forma, a prática articulatória hegemônica (assim como a formação discursiva hegemônica) está sempre baseada num "fundamento contingente":

\begin{abstract}
Não há um substrato, uma natura naturans a partir da qual as articulações sociais existentes poderiam ser explicadas. Essas articulações não são as superestruturas de nada, mas o terreno primário na constituição da objetividade social. Isto implica que há uma contingência essencial (Laclau, 2008, p. 51).
\end{abstract}

Porém, a presença da contingência não significa que as práticas articulatórias "possam se deslocar em qualquer momento em qualquer direção" (loc. cit.). Como vimos acima, o ponto nodal tem certa estabilidade, ainda que esta estabilidade seja construída sobre uma pluralidade de elementos heterogêneos. Em outras palavras, a homogeneidade é construída sobre heterogeneidades que se ligam umas às outras por meio de relações equivalenciais.

Torna-se claro aqui o elemento pós-fundacionalista do pensamento de Laclau. De acordo com Oliver Marchart, o pós-fundacionalismo não pode ser confundido com o anti-fundacionalismo ou com um pós-modernismo do "vale tudo". Enquanto o anti-fundacionalismo se insurge contra o fundamento, o pósfundacionalismo não pretende desacreditar o fundamento, mas apenas debilitar seu status ontológico. "O debilitamento ontológico do fundamento não conduz à ausência total de todos os fundamentos, mas à impossibilidade de um fundamento último" (Marchart, 2007, p. 29).

As teorias pós-fundacionalistas baseiam-se na diferença ontológica entre o político (entendido como uma dimensão ontológica da sociedade) e a política (as 
práticas ônticas da política convencional, como certas formas de ação, o subsistema político). A dimensão do político revela que a sociedade não pode basear-se em um fundamento, a não ser que ele seja "contingente", como apontado por Butler.

Vários movimentos hegemônicos tentam fundar a sociedade sem ser inteiramente capazes de fazê-lo. Isto porque toda fundação é parcial (o ponto nodal de Laclau também é uma fixação parcial). Segundo Marchart, o político (a dimensão ontológica) se retira no momento mesmo em que funda o social. Como consequência, a sociedade tentará, em vão, buscar um "fundamento último" na política (partidos, sistemas de governo), mas esta só tem a oferecer um "fundamento efêmero e contingente".

Em suma, o pensamento pós-fundacionalista não abandona a busca do fundamento; mas, partindo da diferença ontológica entre o político e a política, sabe que qualquer fundamento encontrado será sempre contingente. Diríamos que o encontro do fundamento é impossível, mas sua busca é indispensável. Não podemos abrir mão da tentativa de buscar o fundamento.

Neste sentido, o pensamento de Derrida é marcado por um pósfundacionalismo e não um anti-fundacionalismo. Como veremos à frente com mais detalhes, a desconstrução não pode ser considerada anti-fundacional porque ela não se propõe a liquidar o fundamento, mas apenas enfraquecer seu "status ontológico", mostrando seu caráter contingente, construído, efêmero. Aceitar que o fundamento é contingente equivale a questionar a existência de um significado em si:

independente do sistema linguístico-conceitual em que ele se encontra, como se a linguagem, tanto falada quanto escrita, servisse apenas para expressar, transportar ou comunicar, num segundo momento, um sentido em si mesmo já previamente existente (Duque-Estrada, 2002, p.18).

Um outro aspecto do pós-fundacionalismo é que ele não se detém depois de supor a ausência de um fundamento final e, por isso, não se converte em um nihilismo anti-fundacional. O que está implícito em Laclau é que é perfeitamente plausível construir a política sobre o pilar do fundamento contingente. É só isto que temos, mas já é o suficiente. Em Derrida, a tentativa de estabelecer um fundamento contingente aparece no conceito de "posição". Mesmo consciente do 
caráter contingente de qualquer "posição" (mesmo sabendo que ela será desconstruída a qualquer momento), o seu estabelecimento é necessário para que se possa atuar politicamente num determinado momento. A posição seria a encarnação do universal no particular, sem resvalar para a reificação.

De um ponto de vista pós-fundacionalista, a memória e a identidade de um grupo não são, portanto, constituídas a partir de um fundamento (um passado, uma etnia), mas surgem a partir de articulações baseadas em um "fundamento contingente”. Nesse sentido, a identidade de um grupo não está relacionada a um substrato que o uniria naturalmente. Não há natura naturans, como destacou Laclau. Ao contrário, a identidade é construída de modo contingencial: a eliminação das diferenças dentro de um grupo (a criação da identidade) se torna possível porque essas diferenças são igualizadas em relação a um outro grupo (o outside constitutivo). Para Laclau, o outside tem uma função revelatória na medida em que mostra a natureza contingente da objetividade.

Como vimos no capítulo 2, o discurso sobre valores asiáticos, latinoamericanos ou ocidentais tenta estabelecer como natura naturans o que é historicamente contingente. Tenta-se criar uma identidade asiática, latino-americana ou ocidental a partir da fixação de pontos nodais em torno de determinadas características. É isto, por exemplo, o que faz Samuel Huntington ao reduzir as identidades de diferentes grupos a um único ponto nodal (o religioso) e, desta forma, traçar fronteiras intransponíveis entre as civilizações.

É justamente o fato de o fundamento ser contingente, ou seja, de não haver um "fundamento do fundamento", que permite a abertura e o exercício da liberdade. O conceito de liberdade com o qual estamos lidando relaciona-se a um movimento de fundar, mas um fundar que é sempre provisório. A liberdade dá fundamento e, ao mesmo tempo, o toma. Este processo ininterrupto de fundar e desfundar é uma condição da significação, ou seja, para que a significação seja possível (o fundar), a ruptura da significação (o desfundar) é uma pré-condição necessária.

Como vimos em Laclau e Mouffe, o momento da crise é aquele em que a significação colapsa e a contingência é revelada. É importante notar que o status da contingência é suprahistórico (por isso, ela é necessária), mas a experiência da contingência e sua realização estão submetidas a condições histórico-empíricas. Retomando a explicação de Laclau, podemos dizer que o universal (supra- 
histórico) só se manifesta ao encarnar no particular histórico-empírico. Desta forma, a compreensão da crise como "contingência" está sempre histórica e contextualmente localizada.

Ao conectar o supra-histórico com o empírico-histórico, esta elaboração teórica impede que cometamos o erro do textualismo e do contextualismo. O primeiro tipo de erro privilegia o texto, enfatizando a autonomia das articulações entre os significantes em relação ao contexto (neste caso, qualquer fundamento é abolido). $\mathrm{O}$ erro oposto, o do contextualismo, tenderia a compreender o contexto histórico-empírico como um fundamento e a prática discursiva como mero epifenômeno que emana do substrato contextual. Tanto no textualismo quanto no contextualismo, há uma separação entre práticas discursivas e não-discursivas.

Em contraste, a relação do supra-histórico com o empírico-histórico (ou a encarnação do universal no particular) permite que adotemos uma abordagem distante do contextualismo. Em vez de o fundamento estar localizado no contexto (contextualismo), ele é produzido no momento da encarnação do universal num contexto histórico-empírico particular. Ao mesmo tempo, este fundamento é contingente porque outras encarnações do universal (outras fundações) irão sucedê-lo.

É a partir desta perspectiva pós-fundacionalista que Laclau e Mouffe irão interpretar o conceito de "formação discursiva" de Foucault. Se a formação discursiva é composta por regularidades e dispersões, como veremos mais à frente, então uma interpretação pós-fundacionalista da "formação discursiva" deveria associar as regularidades à dimensão supra-histórica e as dispersões aos momentos de encarnação do universal numa articulação particular histórico-empírica.

As articulações de significantes funcionam com base em duas lógicas opostas que fixam e, ao mesmo tempo, subvertem significados (e consequentemente identidades): a lógica da diferença e a lógica da equivalência. A lógica da diferença tenta fixar as posições dos agentes sociais como estáveis. Presume-se que as identidades estejam baseadas em "essências", em "fundamentos". Desta forma, elas são representadas como diferentes de outras identidades também essenciais, como se houvesse uma fronteira rígida entre as identidades. Já a lógica da equivalência revela a natureza contingente e instável das identidades. Aqui, a identidade é apresentada como uma construção discursiva e não como algo que teria uma "essência" ou um "fundamento". Como as duas lógicas atuam simultaneamente, podemos dizer que sua combinação resulta numa lógica pós- 
fundacionalista. O que a lógica da diferença "funda" como essência é "desfundado" pela lógica da equivalência, ou seja, há fundamento, mas ele é contingente.

\section{2}

\section{Uma concepção de história pós-fundacionalista e pós-colonialista}

A memória do homem não é uma soma: é uma desordem de possibilidades indefinidas

Jorge Luís Borges

Nas últimas décadas, os historiadores têm trabalhado com a questão da memória e da experiência, especialmente quando esta é vivida por grupos marginalizados que não puderam registrar sua trajetória em documentos oficiais. Esta abordagem resultou numa nova maneira de ler os arquivos. Em vez de tomar os dados do arquivo como um material representativo da verdade que apenas precisaria ser revelado e organizado pelo historiador, passou-se a questionar como esses arquivos foram construídos e mantidos e como determinados silêncios se instalaram. Em suma, em vez de perguntarmos o que o arquivo é, tentamos investigar as condições de possibilidade que permitiram a sua formação.

O arquivo não é uma mera coleção de fatos, mas já é ele próprio uma préseleção de dados realizada de acordo com certos interesses como, por exemplo, os interesses do Estado ou de uma instituição religiosa. Em última análise, estamos tratando também aqui de "pontos nodais" que se fixam num determinado momento como a narrativa hegemônica.

$\mathrm{Na}$ abordagem historiográfica tradicional, pressupõe-se que o arquivo seja a fonte do conhecimento e que bastaria acessá-lo para recuperar a história de um determinado período. Este paradigma de pesquisa positivista valoriza a coleta e análise da informação sobre um objeto de estudo. Além disso, trabalha com uma ideia de ciência na qual existiria uma nítida separação entre o observador e o observado. A pesquisa nada mais é do que a tentativa de confirmar ou não, por meio de investigação empírica, hipóteses levantadas pelo observador sobre o observado.

A partir da "virada linguística" ocorrida na disciplina historiográfica, reconheceu-se a natureza problemática da linguagem, que antes era tomada simples- 
mente como um meio transparente utilizado para veicular os dados encontrados no arquivo histórico. De acordo com a concepção pós-estruturalista da linguagem, o historiador é um observador que está constitutivamente implicado no objeto da pesquisa. Consequentemente, a "virada linguística" na historiografia abriu a possibilidade de contribuições da literatura e da teoria crítica, tornado mais flexíveis as fronteiras entre as diversas disciplinas.

A linguagem tem um papel na constituição do objeto e, portanto, as afirmações históricas dependem de "traços textualizados" (Lacapra, 2000, p. 26). Embora a contextualização seja necessária para a compreensão histórica, ela não pode ser tomada como o único modo de explicação. A hipercontextualização não raro objetifica, reifica e fixa o passado. Contra este risco, os estudos históricos recentes recorrem ao texto como uma forma de questionar os contextos de produção e recepção. Como explica Dominick LaCapra, “o texto pode repensar o contexto" (2004, p. 17), gerando implicações sociais e políticas.

O questionamento do arquivo é um exemplo de como o texto pode repensar o contexto, considerando que o termo "texto" não se refere exclusivamente a material escrito, mas abarca toda a ordem dos signos. Assim, uma voz, um retrato ou uma imagem também são "texto". Segundo LaCapra, os textos podem ter uma dimensão trans-histórica que "não pode ser explicada em termos contextuais estritamente circunstanciais ou imediatos" (2004, p. 18). Esta dimensão trans-histórica está relacionada à capacidade do texto de desafiar leitores contemporâneos, apresentando-lhes problemas.

Na perspectiva historiográfica tradicional, o arquivo é tomado como fundacional, arcaico, ou seja, é nele que está guardada a história fundadora de uma determinada coletividade. Mas ele também tem um viés normativo, ao indicar o caminho que deve ser seguido pela comunidade se quiser preservar sua origem. É a partir dele que uma comunidade pode relembrar seu passado e construir ou reafirmar sua identidade. Temos, portanto, um "fetichismo arquivista" na historiografia tradicional.

Esta concepção do arquivo foi criticada por Derrida em Mal de Arquivo (2001). O "mal de arquivo" seria o desejo de lembrar a origem, que resulta de

\footnotetext{
${ }^{13}$ Em francês, a expressão "mal de" originalmente se referia a uma mulher em trabalho de parto, que estaria "en mal d'enfant". Por analogia, o termo passou a designar uma vontade para fazer algo. Assim, "mal d'archive" seria um desejo irresistível pela procura nos arquivos.
} 
uma falta originária e estrutural da memória. Ele é também uma tentativa de fixar o significado do passado, preenchendo as falhas da memória a partir da procura incessante nos arquivos. $\mathrm{O}$ mal de arquivo "é dirigir-se a ele com um desejo compulsivo, repetitivo e nostálgico, um desejo irreprimível de retorno à origem, uma dor da pátria, uma saudade de casa, uma nostalgia do retorno ao lugar mais arcaico do começo absoluto" (Derrida, 2001, p.118). A historiografia tradicional sofre, portanto, do mal de arquivo na medida em que considera os documentos oficiais como a principal fonte de pesquisa, o lugar onde o começo absoluto pode ser encontrado.

Em outro texto, Freud e a cena da escritura, Derrida aponta a semelhança entre a ideia de inconsciente em Freud e a concepção de arquivo. Na obra freudiana, o inconsciente seria o arquivo da memória, o lugar onde todas as impressões são depositadas. No entanto, lembra Derrida, o conteúdo do inconsciente não pode ser resgatado completamente; ele só se torna acessível por modos de interpretação suplementares. Portanto, a falta originária e estrutural da memória nunca poderá ser completamente preenchida. O que temos é uma recriação (uma interpretação suplementar) daquilo que foi vivido ou, para retomar um tema borgiano, uma ficcionalização da memória.

As concepções historiográficas recentes consideram que a memória está relacionada a uma versão do passado (aquela que se pode seletivamente recordar) e não com o passado mesmo, ou seja, com um fundamento. A memória é construída com base num "fundamento contingente", formado pela articulação seletiva de significantes. Margaret Kohn e Keally McBride apontam para a emergência de histórias e mitos que surgem post facto para explicar a fundação de um novo regime. Embora tais narrativas pretendam revelar um fundamento (passado) que já existiria como tal e estaria apenas sendo resgatado, o que acontece de fato é uma “invenção do passado que serve ao presente” (Kohn, McBride, 2011, p. 14).

Estas histórias excluem alguns detalhes e inventam outros. Eventualmente, elas são contestadas por outros grupos que tentam "incluir características esquecidas e revisar a narrativa para torná-la historicamente mais acurada" (loc. cit.). As disputas em torno dessas narrativas revelam a existência de um "fundamento contingente", que, apesar de apresentar certa estabilidade, não está imune à contesta- 
ção e à revisão. É este o momento da disputa hegemônica, em que cada grupo tenta fixar o significado do "significante vazio", criando um novo fundamento.

A crítica à nova abordagem historiográfica surgiu ainda nos anos 80 e 90, quando Christopher Norris, entre outros, defendeu a incompatibilidade entre a história e disciplinas como a literatura ou a teoria crítica. Os textos literários ou filosóficos seriam fontes não confiáveis pois não trazem evidências sobre o mundo. Logo, a desconstrução, geralmente utilizada na crítica literária, não seia um "método de leitura" confiável para a história, pois ela poderia subverter o sentido tradicional desses textos. No entanto, segundo Norris, a desconstrução seria inadequada para um texto histórico construído a partir de arquivos confiáveis. Este tipo de comentário pressupõe o arquivo como algo sagrado ${ }^{14}$, não passível de desconstrução e reinterpretação.

Ao contrário de Norris, entendemos que não só é possível, como desejável, associar a história a outras disciplinas ou teorias. Um ponto em comum entre alguns dos autores que usaremos como arcabouço teórico desta tese - Foucault, Bakhtin, Derrida - é justamente a forma como concebem a disciplina histórica numa perspectiva pós-positivista (o que será visto nas próximas seções). Um de nossos desafios é mostrar a compatibilidade entre estes autores, já que nem sempre suas teorias se mesclam de forma espontânea, apesar de professarem concepções de história convergentes. No entanto, a associação entre esses autores e sua utilização na análise é possível. "Pode-se empregar e até combinar duas ou mais abordagens" (Lacapra, 2000, p.29).

Uma leitura desconstrutiva radical nos levaria a nos concentrar no jogo do significado, um jogo arbitrário, mecânico e desumano. Teríamos um modo de análise demasiado abstrato, no qual a especificidade se perderia. Esta visão desconstrutiva radical é geralmente associada a Paul de Man, embora Derrida, para alguns autores, também pareça, em alguns momentos, se aproximar da abordagem de De Man.

A desconstrução, como veremos à frente, se detém na análise de "forças dialogizadas" no interior de um texto, que muitas vezes contrariam a intenção do

\footnotetext{
${ }^{14}$ Se o arquivo é considerado sagrado pelos historiadores e apenas eles têm acesso aos documentos, talvez pudéssemos resgatar aqui o conceito de profanação de Giorgio Agamben como uma tentativa de contestar este monopólio. De acordo com este autor, profanar significa restituir as coisas ao livre uso dos homens; no caso em tela, a profanação tornaria o arquivo não só mais acessível, mas incluiria a possibilidade de questionar o modo como ele foi construído.
} 
autor. A desconstrução se caracteriza ainda pela inversão e deslocamento de oposições binárias hierarquizadas. O resultado do deslocamento é uma redefinição do termo subordinado. Porém, Derrida nos alerta justamente para o fato de que o deslocamento não produz um jogo arbitrário de proliferação de significados. A desconstrução não busca uma polissemia dos conceitos, mas uma disseminação. Ao contrário da polissemia, em que múltiplos níveis semânticos são invocados e superpostos, convergindo numa síntese, na polissemia temos uma explosão do horizonte semântico e a instauração de um indecidível. No lugar da síntese entre dois termos, somos confrontados com a indecidibilidade entre dois termos. Na formulação de Duque-Estrada, podemos perceber que a distinção entre polissemia e disseminação está relacionada à possibilidade ou não de retorno ao sentido anterior:

\begin{abstract}
A polissemia comporta a ideia de uma saída de si - na proliferação de níveis semânticos - e de um retorno a si - em direção à plenitude da palavra integral -, numa espécie de movimento re-preenchedor da linguagem e, portanto, numa dialética regulada pelo horizonte do mesmo. (...) A "lógica" da disseminação introduz algo inteiramente distinto: ela não somente rompe com o caminho de volta, mas com a própria ideia de matriz, introduzindo a diferença no interior do mesmo" (Duque-Estrada, 2002, p. 14).
\end{abstract}

O risco da disseminação (a reescrita, a rearticulação) é que podemos recair numa descontextualização excessiva em que segmentos de textos seriam desconectados do tempo e do espaço em que emergiram para adquirirem outros significados. É por esta razão que a desconstrução e a disseminação são por vezes acusadas de serem a-históricas, de negarem o contexto e investirem numa hipertextualização. Mas este não é um desdobramento necessário da desconstrução e da disseminação. Elas podem adquirir uma dimensão mais crítica e política (o que será retomado na seção deste capítulo sobre Derrida).

Ao optarmos por Bakhtin e apontar suas semelhanças com Derrida, estamos procurando justamente enfatizar o papel do contexto na obra do último. Bakhtin critica Saussure por seu formalismo abstrato e a-histórico e defende uma linguagem historicamente situada, contextualizada. A proposta de Derrida não é diferente, pois critica o formalismo estruturalista de Saussure e propõe uma estratégia pós-estruturalista que leve em consideração o contexto. Segundo Lacapra, uma leitura dialogizada baseada na teoria de Bakhtin pode apresentar semelhanças com a desconstrução. Isto porque o dialogismo "refere-se a um jogo de forças na 
linguagem" (2000, p.64). Mas existe um aspecto sob o qual o dialogismo pode se aproximar da desconstrução. Ambos têm imenso poder de provocação, questionando pressupostos e propondo releituras.

Em relação ao trabalho com o contexto, podemos ainda citar Foucault, em cuja obra encontramos a relação do significado com o poder e as instituições de uma determinada época (contexto). Portanto, os três autores utilizados como marco teórico de nossa análise compartilham uma preocupação com uma linguagem historicamente situada.

Pensar o fazer historiográfico a partir do dialogismo bakhtiniano significa ir contra o predomínio de uma única voz temporal na concepção de história. É preciso enfatizar um "tempo histórico dialógico", que exploraria o passado de maneira que ele não se configure como causa ou precedente do atual, ou seja, nega-se uma concepção unilinear e teleológica de história. Esta abordagem evitaria uma assimilação do passado por valores e conceitos do presente. Em outras palavras, não correríamos o risco de uma presentificação, uma submissão ou conformismo ao presente.

Como propunha Nietzsche, devemos tomar o contemporâneo como intempestivo, ou seja, dissociado e desconectado do presente. Somos contemporâneos quando não coincidimos perfeitamente com o nosso tempo. "Mas, exatamente por isso, exatamente através desse deslocamento e desse anacronismo, ele é capaz, mais do que os outros, de perceber e apreender o seu tempo" (Agamben, 2009, p. 58-59). Inversamente, destaca Agamben, “aqueles que coincidem muito plenamente com a época, que em todos os aspectos a esta aderem perfeitamente, não são contemporâneos porque, exatamente por isso, não conseguem vê-la, não podem manter fixo o olhar sobre ela" (loc. cit.). Agamben vai além da definição nietzschiana. O contemporâneo seria não apenas aquele que mantém fixo o olhar no seu tempo, mas o que consegue neutralizar as luzes de sua época para descobrir o lado obscuro do presente. A partir desta obscuridade do presente, podemos inquirir o passado, que, por sua vez, poderá iluminar as trevas do presente.

Este processo, no entanto, nos exigirá incluir na análise uma perspectiva pós-colonialista sobre a história. O lado oculto - e obscuro - da modernidade é a colonialidade, mas esta constatação só é possível quando abandonamos a visão de uma história unilinear eurocêntrica, em que a colonialidade faria parte do passado e a modernidade do presente. Em outras palavras, só percebemos a coexistência de 
modernidade e colonialidade quando, sendo contemporâneos, conseguimos neutralizar as luzes excessivamente ofuscantes da modernidade.

Os autores pós-colonialistas - e voltaremos a este tema em outras partes deste capítulo - apresentam uma visão de história que incorpora contribuições pós-estruturalistas, mas vai além delas, introduzindo a discussão sobre a diferença colonial. Para eles, o pós-estruturalismo precisa ser complementado por uma reflexão feita a partir das margens do sistema. Se os pós-estruturalistas contestam a Filosofia da História de Hegel e os grandes esquemas narrativos, eles o fazem a partir do centro do sistema. Ao contrário, os chamados pós-colonialistas procuram pensar a partir de um continente - a América - que havia sido silenciado na história linear de Hegel.

Em Europe, Modernity and Eurocentrism, Enrique Dussel mostra como a História centrada na Europa é uma construção intelectual. Ao contrário do que costumamos pensar, a Grécia não é o berço da Europa:

A diacronia unilinear Grécia-Roma-Europa é uma construção ideológica que remonta ao romanticismo alemão do final do século XVIII. Assim, a linha única de desenvolvimento Grécia-Roma-Europa é um subproduto conceitual do 'modelo ariano' eurocêntrico (Dussel, 2000, p.1-2).

Segundo Dussel, no período áureo da Grécia (V a.c), as regiões mais desenvolvidas eram a Ásia (Turquia) e a África (Egito). Para os gregos, a Europa não era nem sequer um problema. Portanto, a região que veio a se tornar a Europa moderna nunca esteve próxima culturalmente da Grécia originária, como nos fazem crer os relatos eurocêntricos. Pelo contrário, a República Romana e, depois, o Império Romano do Ocidente, falavam latim, enquanto os gregos utilizavam sua própria língua para se comunicarem com os árabes. Portanto, romanos e gregos faziam parte de dois mundos completamente autossuficientes.

Este isolamento será rompido no século VII, quando o Império Romano do Oriente (o Império Romano do Ocidente caíra em 476 a.c.) confronta o mundo islâmico. É só a partir deste momento que a cultura clássica grega, que já era próxima do mundo árabe muçulmano, terá mais contato com a cultura cristã bizantina do Império Romano do Oriente.

Mas expansão do Islã a partir do século VII colocará a Europa medieval numa posição periférica. Como já amplamente divulgado, Aristóteles estava mais 
próximo do mundo árabe do que do cristão. Era lido em Bagdá antes de ser traduzido para o latim na Espanha e depois alcançar Paris no fim do século XII.

Durante a Renascença Italiana, pela primeira vez o Ocidente Latino se juntará aos gregos para se contrapor aos turcos, sendo que estes deixarão de reivindicar a partir deste momento a origem helênica e bizantina do mundo muçulmano. Estaria então aberto o caminho, segundo Dussel, para a cadeia de significantes Grécia-Roma-Europa. A herança grega teria sido "sequestrada" (Dussel, 2000, p. 468) para a narrativa da Europa moderna.

A narrativa hegemônica é a da centralidade da Europa e de uma modernidade europeia. Nesta perspectiva, a modernidade é lida como um processo de emancipação da imaturidade da razão para a racionalidade. Se no século XIX este relato aparece na Filosofia da História de Hegel, no século XX uma nova versão estará presente no pensamento de Jürgen Habermas, para quem “os eventos históricos chaves para a criação do princípio da subjetividade moderna são a Reforma, o Iluminismo e a Revolução Francesa” (apud Dussel, 2000, p. 469). Um outro intelectual contemporâneo, Zygmunt Bauman, afirma que "no que se refere à história, a Europa foi definitivamente um país exportador, apresentando (até bem recentemente) uma balança de comércio exterior consistentemente positiva" (2004, p.14). Teríamos, portanto, uma sequência histórica completamente centrada na Europa e sem qualquer influência da América neste processo. É a Europa que produz e exporta a História.

Uma outra narrativa da modernidade aparecerá nos textos de autores póscolonialistas como Aníbal Quijano (ver capítulo 2), Fernando Coronil, Enrique Dussel e Walter Mignolo. Antes de 1492, ou seja, antes da chegada de Cristóvão Colombro à América, não podemos falar em uma história global. Com a invasão e não "descoberta" - da América, o circuito atlântico substitui o mediterrânico e Espanha e Portugal passam a contribuir para a formação da Europa. Na visão desses autores, a Ibéria ocupa lugar central na modernidade e na constituição da subjetividade moderna. Holanda, Inglaterra e França vão apenas seguir o caminho iniciado pela Espanha e por Portugal.

No entanto, na narrativa hegemônica sobre a modernidade - aquela presente tanto em Hegel quanto em Habermas -, a contribuição de Espanha e Portugal no século XVI é silenciada pois este período é associado à Idade Média. Na interpretação de Dussel, a conquista da América é a condição de possibilidade para a Eu- 
ropa conseguir uma vantagem comparativa em relação a seus vizinhos do Oriente (Turcos, Muçulmanos, Chineses). É por este motivo que Mignolo enfatizará que, antes do orientalismo, tivemos ocidentalismo. Foi a subjugação do extremo ocidente (a América) que permitiu à Europa instituir-se como sujeito moderno conhecedor do Oriente (objeto) e criar o orientalismo. Como vimos no capítulo 1 , Quijano chama a atenção para a co-constituição identitária entre a Europa e a América Latina, o que também as torna contemporâneas. Neste sentido, a América Latina entrou na modernidade como o primeiro "Outro" que seria submetido e explorado. Após fortalecer-se nesta co-constituição com a América Latina, a Europa pode voltar-se para a exploração do Oriente.

Uma narrativa histórica alternativa, constituída a partir da América Latina, procura desvendar o lado obscuro da modernidade. Esta, apresentada como o auge da racionalidade, também possui seu momento de irracionalidade, representado pelo colonialismo. Mais: não se trata de superar a razão como tal, mas apenas seu lado violento, abrindo a possibilidade para o que Dussel chama de transmodernidade: "a transmodernidade seria um projeto mundial de liberação ética no qual a alteridade (...) poderia tornar-se plena" (2000, p. 473).

Uma história escrita a partir da América Latina não usaria, por exemplo, a expressão "descoberta da América”, mas sim o termo "invasão". Segundo Dussel, para os povos que aqui habitavam, tratou-se de uma invasão a seu território e destruição de seu modo de vida. A "descoberta" pressupõe um sujeito europeu que realiza uma ação de des-vendar, des-cobrir um objeto (a América) que estava encoberto. Consequentemente, esta narrativa tradicional - reiterada em 1992 pela Espanha, por ocasião dos 500 anos da "descoberta" - nega a agência da América Latina, representando o continente como uma massa apática que teria sido descoberta e moldada de acordo com os valores europeus.

Na Filosofia da História de Hegel, a América Latina está localizada fora da História; ela teria sido um lugar vazio até a chegada dos europeus, que assumiram o fardo de transmitirem seus valores ao continente até que ele atingisse o nível alcançado pela Europa. Portanto, o eurocentrismo resulta no que Dussel denominará "desenvolvimentalismo":

o pensamento de que o caminho seguido pelo desenvolvimento moderno da Europa pode ser seguido unilateralmente por qualquer outra cultura. O desenvolvi- 
mento é considerado aqui como uma categoria ontológica, e não apenas como uma categoria sociológica ou econômica. Ele é o 'movimento necessário' do Ser para Hegel (Dussel, 1995, p. 68).

Na concepção hegeliana, o desenvolvimento é dialeticamente linear e tem uma direção determinada, um "movimento necessário" do Oriente para o Ocidente, sendo o Ocidente europeu o ponto de chegada do desenvolvimento do Espírito Absoluto. Nesta trajetória, a América Latina e a África estão ausentes devido à sua localização no hemisfério Sul. Dussel chama a atenção para o fato de ambas serem consideradas por Hegel como regiões ainda na infância e que não teriam História. Consequentemente, seus povos também estariam numa situação de imaturidade, precisando ser conduzidos pelos civilizados europeus. Mas não por qualquer europeu. Aqui também Hegel fará distinções entre a Europa do Sul (Portugal, Espanha, sul da França e Itália) e a do Norte e do Noroeste (Alemanha, Inglaterra, França e os países escandinavos). Embora o sul europeu tenha tido importância na antiguidade, ele não carrega o desenvolvimento em seu núcleo. Esta característica pertenceria à Europa do Norte e do Noroeste. Em suma, Hegel não só relega a América Latina a um lugar fora da História, mas minimiza o papel de Portugal e Espanha no desenvolvimento da modernidade. As relações entre os países ibéricos e a América Latina no século XVI não são consideradas fundamentais para a compreensão da modernidade.

Na filosofia hegeliana, não há, portanto, a co-constituição e a contemporaneidade entre Europa e América Latina apontadas por Quijano. Negar a contemporaneidade significa colocar a Europa como modelo para a América Latina. Como lembra Fernando Coronil, este "modo de historicidade satura a vida política com a síndrome do 'ainda não', uma perspectiva que descreve algumas sociedades como sempre 'ainda não' civilizadas, 'ainda não' industrializadas, 'ainda não' modernas" (Coronil, 2011, p. 246). O advérbio de tempo "ainda" coloca as sociedades contemporâneas numa escala temporal. Ele realiza o que o antropólogo Johannes Fabian chama de "negação da contemporaneidade" (FABIAN, apud CORONIL, 2011, p.246), quando sociedades que coexistem na contemporaneidade são distribuídas em períodos históricos diferentes.

Contra uma Filosofia da História hegeliana, Dussel recorre ao pensador latino-americano Leopoldo Zea, que defendia uma "filosofia da história da América 
Latina" distinta da filosofia da história europeia e ocidental. Em Zea, a concepção de história não é a de uma sucessão linear de acontecimentos rumo a um aperfeiçoamento da Humanidade, como aparece em Kant e Hegel. A História aqui ganha o sentido de um "acontecimento" ou "evento" situado no nível da vida cotidiana; uma conscientização dos latino-americanos sobre sua própria história.

No entanto, Dussel considera que essa conscientização proposta por Zea seria apenas um primeiro passo. Precisaríamos, diz Dussel, de mais do que conscientização, precisaríamos de uma filosofia latino-americana que possa dialogar com a filosofia hegemônica euro-norte-americana.

Historicamente, a comunidade filosófica euro-norte-americana - e também a comunidade filosófica hegemônica na América Latina - sempre ignorou as filosofias periféricas, condenando-as a um lugar "fora da história da filosofia". Também em termos epistemológicos e filosóficos, a América Latina é o "Outro" da comunidade filosófica euro-norte-americana. A "ligação ocidental" estabelecese aqui claramente nesta exclusão da América Latina como o lugar que produz uma "outra filosofia".

Por esta razão, não basta recorrermos a uma história do "pensamento latino-americano", como tem sido feito por vários autores. Referir-se simplesmente a um pensamento latino-americano é muito vago e não implica necessariamente a constituição de uma filosofia no sentido estrito. O que Dussel defende é uma utilização do discurso, da problemática e dos métodos da "comunidade filosófica hegemônica" para elaborarmos uma filosofia no sentido estrito que possa interpelar aquela comunidade hegemônica. Ela poderia ainda introduzir no debate problemáticas e categorias até agora ausentes da filosofia euro-norte-americana. Mas, apesar de ser uma "filosofia no sentido estrito", ela difere da filosofia euro-norteamericana por ser marginal, explorada.

A nosso ver, a proposta de Dussel pode ser interpretada como uma tentativa de evitar uma polarização entre uma filosofia "essencialmente" europeia e outra "essencialmente" latino-americana. O reconhecimento de que a filosofia latinoamericana é marginal não significa que ela deva abrir mão do rigor metodológico pois este não é uma exclusividade do discurso hegemônico filosófico europeu. Se nos contentássemos com um pensamento latino-americano como mera reflexão sobre nossa posição periférica, estaríamos contribuindo para reforçar a dicotomia entre "Europa/razão" e "América Latina/sentimento". Parece ser isto que Dussel 
quer evitar (ele não renega o racionalismo iluminista; apenas seu lado irracional e violento). Ao mesmo tempo, adotar o rigor metodológico do discurso filosófico hegemônico não equivale a "imitar" a filosofia europeia. Ao contrário, a filosofia produzida a partir da periferia significa uma "razão do Outro" (Dussel, 1993, p. 75) que produz categorias inéditas.

Um exemplo de pensamento elaborado a partir da América Latina pode ser ilustrada pelo conceito de perspectivismo ameríndio, cunhado por Eduardo Viveiros de Castro. O perspectivismo ameríndio seria um "outro pensamento" capaz de interpelar a filosofia e a modernidade ocidentais. O perspectivismo ameríndio não pressupõe categorias como "sujeito" e "substância"; estes não existem a priori, mas são produto de uma relação. Esta concepção subverte a tradição filosófica europeia, a qual toma a substância como um dado e as relações como uma consequência.

Poderíamos dizer que o privilégio da relação sobre a substância também é uma característica do pensamento pós-positivista desenvolvido por europeus. O poder em Foucault não é uma substância, mas uma relação. E o conceito de différance de Derrida é primordialmente relacional; o sentido só se produz a partir de uma relação entre os significantes. No entanto, não pretendemos equiparar o pensamento ameríndio ao pensamento pós-positivista europeu; o pós-positivismo europeu não leva em conta a diferença colonial. Justamente para chamar a atenção para nossa especificidade, Viveiros de Castro utiliza o termo "diferonça", uma mistura da différance de Derrida com a palavra "onça", que faria referência ao universo ameríndio. No perspectivismo, a relação adquire uma característica diferente da que aparece no pós-positivismo: a incorporação. A diferonça é uma relação de incorporação canibal. O modo básico de relacionamento ameríndio é a caça, a predação do outro.

Historicamente, a incorporação canibal foi associada ao mito pelo pensamento hegemônico eurocêntrico. Como explicar o canibalismo a não ser por meio dos mitos e da des-razão presentes nas culturas ameríndias? O perspectivismo ameríndio resgata o mito do canibalismo de seu lugar de conhecimento subalterno e destituído de razão. O mito canibal não é o oposto da razão, mas um pensamento rigoroso - como queria Dussel - sobre incorporação, predação, transformação a partir da periferia e da diferença colonial. Em suma, pode-se falar de um "cogito canibal” (Viveiros de Castro, 1986). 
No entanto, este cogito se caracteriza por negar qualquer tipo de dogma. Viveiros de Castro mostrou que o tema da inconstância da alma selvagem (Il selvaggio è mobile) era bastante comum nos relatos dos europeus sobre os ameríndios. O problema dos índios não estava na falta de inteligência, mas na ausência de duas outras potências da alma: a memória e a vontade. Tudo o que aprendiam rapidamente era esquecido em pouco tempo e substituído por novos conhecimentos. Não se fixava em suas mentes, comprometendo o trabalho dos missionários.

Esta interpretação teria, em parte, algum fundamento. "Ela de fato corresponde a algo que se pode experimentar na convivência com muitas sociedades ameríndias" (Viveiros de Castro, 2001, p. 191). A concepção ocidental de cultura pressupõe uma paisagem povoada por estátuas de mármore, ou seja, toda sociedade tende a perseverar no seu próprio ser. Nossas identidades, tradições, memórias são constituídas no mármore e custam a ser modificadas. Na linguagem do Padre Antonio Vieira, citado por Viveiros de Castro, estas seriam nações de mármore. Ao contrário, no cogito canibal, o conhecimento é rapidamente aprendido, mas também esquecido. Teríamos então nações de murta, na definição de Vieira.

A inconstância não ocorre apenas em relação ao "cardápio ideológico ocidental, mas também, e de um modo ainda mais difícil de analisar, de sua relação consigo mesmas, com suas próprias e 'autênticas' ideias e instituições” (Idem). Essa inconstância resultaria numa "abertura ao outro", como já havia assinalado Claude Lévi-Strauss. Em seu estudo sobre a tribo tupi-guarani dos Araweté, Eduardo Viveiros de Castro havia definido o "cogito canibal" como a "topologia do devir-outro, totalmente contrário ao narcisismo" (1986, p.25). A prática colonial era narcísica porque tentava tornar o outro igual a si próprio, como num jogo de espelhos. Por isso, os conquistadores se arvoravam o direito de levar o cristianismo aos indígenas. Em contraste, o "cogito canibal" quer se tornar o outro, deviroutro, ser absorvido pelo outro. Em vez de narcisismo, há uma entrega e abnegação absolutas. O ato canibal não visa a transformar o outro (como o conquistador narcisista), mas alterar a si próprio com base no outro (quem "come" é que se altera). Ou seja, o canibal não pretende preservar a sua identidade pois não é isto o que lhe importa. Não há substância identitária em meio à inconstância. O que o canibal almeja é o estabelecimento de uma troca, uma relação. Como já dito, o perspectivismo ameríndio não pressupõe um "sujeito" e uma "substância", portan- 
to, não faz sentido preservar uma identidade substancial, como ocorre nas "nações de mármore".

Segundo Viveiros de Castro, a incorporação canibal do outro obriga o homem a sair de si: "o exterior estava em processo incessante de interiorização, e o interior não era mais que movimento para fora" (2011, p. 220). A fronteira presente neste cogito é, portanto, bem diferente daquela que separa o sujeito moderno de seu exterior ou o Estado moderno do ambiente internacional anárquico.

Um outro aspecto do canibalismo apontado pelos antropólogos (Viveiros de Castro, 2011; Obeyesekere, 2005) diz respeito ao diálogo que precedia o ato canibal. A conversa com o Outro não visava a inculcar no outro sua própria cultura (num discurso monológico) e eventualmente puni-lo com o canibalismo caso não se adequasse aos preceitos ensinados. Não se tratava de convencer o outro a ser igual a si. Tanto o matador quanto a vítima conversavam sobre a relação de dependência que se estabeleceria entre seus grupos por meio da vingança canibal. O matador proclamava o ato canibal como vingança de uma ação passada, enquanto a vítima advertia que o seu grupo o vingaria no futuro. Não havia uma relação de subserviência entre o matador e a vítima pois ambos tinham direito à palavra e à construção de uma narrativa. A conversa era dialógica; duas vozes trocavam experiências e relacionavam-se de forma simétrica. A "antropofagia canibal" era dialógica, o Outro tinha a sua alteridade preservada. Esta questão terá implicações para a própria concepção de tempo ameríndia.

Como vimos, na Filosofia da História kantiana e hegeliana, as sociedades se desenvolviam rumo ao estágio já alcançado pela Europa. O outro é assimilado ao modelo europeu e sua voz é inaudível. Poderíamos aqui utilizar a expressão "antropofagia monológica" para caracterizar o processo pelo qual o europeu "engolia" o outro para transformá-lo no seu semelhante. A "Antropofagia monológica" revela o modo de ser europeu em processos como o assimilacionismo, a missão civilizatória, o desenvolvimentismo e a teoria da modernização.

Ao contrário, a antropofagia canibal nos introduz numa concepção de tempo e história dialógica em que a voz da vítima é escutada no mesmo momento em que se ouve a voz do matador. O ato canibal não é o resultado de uma assimetria em que uma cultura superior tenta assimilar outra inferior e situada num estágio de desenvolvimento anterior. A incorporação canibal se realiza entre duas culturas que estão numa relação simétrica: coexistem num mesmo tempo e uma depende 
da outra para a preservação de sua memória. Os inimigos eram os guardiões da memória coletiva:

a memória do grupo - nomes, tatuagens, discursos, cantos - era a memória dos inimigos. Longe de ser uma afirmação obstinada de autonomia por parte dos parceiros desse jogo (como quis Florestan, e mais tarde Pierre Clastres), a guerra de vingança tupinambá era a manifestação de uma heterenomia primeira, o reconhecimento de que a heteronomia era a condição da autonomia (Viveiros de Castro, 2011, p. 241).

\section{3}

\section{História eurocêntrica e pós-desenvolvimento}

A teleologia eurocentrada teorizada por Hegel reaparece nos discursos das décadas de 40 e 50 sobre o desenvolvimento. O discurso sobre o desenvolvimento e a modernização dos países do chamado Terceiro Mundo pressupõe uma trajetória cujo ponto final é representado pelos países europeus e pela América do Norte. Segundo Inayatullah e Blaney, a diferença cultural é transformada em uma diferença temporal que tenderia a ser eliminada com o tempo, o que nos leva à conclusão de que, em última instância, há uma negação da diferença dos países ditos “em desenvolvimento".

Assim, este discurso do desenvolvimento e da modernização defende o que poderíamos denominar um "desenvolvimento monológico" em que a única voz audível é a da Europa e da América do Norte (aqui novamente vemos claramente o western bond). Ou ainda, recorrendo ao termo "antropofagia monológica" que utilizamos na seção anterior, poderíamos pensar num "desenvolvimento antropofágico monológico", no qual o conhecimento do "Norte" sobre desenvolvimento se expande para áreas do globo mais pobres, engolfando-as e submetendo-as a um único modelo.

A análise de Arturo Escobar e outros sobre o discurso do desenvolvimento no século XX revela sua constituição como um dispositivo para a produção cultural, social e econômica do Terceiro Mundo. Os programas de desenvolvimento para o Terceiro Mundo tiveram seu protótipo na missão de 1949 à Colômbia organizada pelo Banco Mundial. O objetivo era levantar dados sobre o país para 
poder formular uma estratégia de desenvolvimento que o retirasse da situação de caos em que se encontrava.

Este programa foi estendido a todos os países considerados subdesenvolvidos. Na análise de Escobar, o desenvolvimento tornou-se um modo de pensamento e uma fonte de práticas onipresente. "O desenvolvimento atingiu o status de certeza no imaginário social" (Escobar, 1995, p. 5). A pergunta que deveríamos nos fazer, diz Escobar, é a de como algumas representações se tornaram dominantes e moldaram a forma pela qual a realidade passou a ser imaginada. Com base no trabalho de Foucault sobre a relação entre discurso e poder, Escobar analisa as condições de possibilidade desse discurso e, consequentemente, revela seu caráter histórico e contingente. Em suma, apesar de seu "status de certeza" no imaginário social, o discurso do desenvolvimento emergiu num determinado contexto histórico-social.

A transformação do desenvolvimento em certeza contou com uma série de processos, como, por exemplo, a profissionalização do tema. O conceito de "profissionalização" refere-se a um conjunto de técnicas e práticas disciplinares que “organizam, administram e controlam a geração, difusão e validação do conhecimento" (Escobar, 1988, p. 430). Em relação ao desenvolvimento, esta profissionalização se deu por meio de centros de estudo em universidades norte-americanas e europeias, missões de aconselhamento do Banco Mundial e cooptação de intelectuais do Terceiro Mundo. Criou-se assim um conhecimento por meio do qual um sujeito, representado por países desenvolvidos ou organizações internacionais, poderia intervir para "salvar" as nações pobres, consideradas como um objeto da ação do Norte. A produção do conhecimento e a profissionalização do tema também contaram com instituições internacionais (ONU) e bilaterais (US Agency for International Development), além de agências regionais e locais do Terceiro Mundo.

De forma mais ampla, esta ideia sobre desenvolvimento deve ser vista como produto de uma cultura específica, a cultura moderna ocidental, que, por sua vez, deu origem à economia ocidental. Noções de produtividade e racionalidade gestadas no ocidente embasaram os preceitos da economia e foram, posteriormente, aplicados a outras regiões por meio da estratégia do desenvolvimento.

Assim, a subjetividade racional moderna dos europeus poderia transformar a subjetividade "ainda não muito racional" da América Latina, em particular, e do 
Terceiro Mundo, em geral. Chandra Mohanty chama a atenção para a presença de uma espécie de "subjetividade subdesenvolvida" (Mohanty apud ESCOBAR, 1995, p. 9) caracterizada por passividade e ignorância. Este tipo de construção teria sido comum no discurso colonial e volta a se manifestar no discurso sobre o desenvolvimento.

Entre essas "subjetividades subdesenvolvidas", podemos mencionar as comunidades indígenas. Para Escobar, a maioria dos antropólogos se coloca dentro ou fora do paradigma desenvolvimentista. Aqueles que atuam dentro do modelo aplicam seus conhecimentos em prol do desenvolvimento de comunidades indígenas. Já os que estão fora do modelo defendem o autenticamente indígena. Porém, o que vemos são comunidades que estão recriando suas identidades no contato com formas de produção globalizadas e, ao mesmo tempo, reafirmando seu lugar e a cultura local. Portanto, longe da ausência de agência a elas atribuída pela concepção hegemônica, as comunidades indígenas atuam na construção de um modelo de desenvolvimento local ou o que Escobar chama de "pósdesenvolvimentismo".

Diríamos que essas comunidades atuam antropofagicamente, abrindo-se ao outro, mas sem imitá-lo em todos os aspectos. Estaríamos diante de uma antropofagia dialógica desenvolvimentista, uma vez que este processo antropofágico não elimina nem submete o outro supostamente mais desenvolvido. O que há é uma incorporação canibal de características do outro, mas não sufocamento do outro. As duas vozes se alternam, se fundem, se fragmentam, criando um desenvolvimento dialógico.

A discussão sobre a agência dos excluídos é fundamental na visão de Escobar e provoca uma reflexão sobre como lidar com a teoria pós-estruturalista em contextos pós-coloniais. Em sua visão, a desconstrução deve ser seguida imediatamente pela reconstrução, de forma a permitir que essas vozes até então excluídas possam se tornar audíveis. Neste ponto, Escobar concorda com a tese de Homi Bhabha (1990, p. 75) sobre a insuficiência da desconstrução para análise de sociedades pós-coloniais. Haveria uma tendência nestas críticas a discutir a alteridade principalmente em termos dos limites do logocentrismo ocidental, deste modo negando a alteridade cultural "envolvida em condições discursivas e históricas específicas" (BHABHA, 1990, p. 73) que requereriam um tipo diferente de estratégia de leitura. 
Em suma, a desconstrução e outras teorias pós-estruturalistas seriam necessárias, mas não suficientes para garantir agência aos excluídos. Como já dito na introdução deste capítulo, não se trata de negar o pós-estruturalismo, mas de complementá-lo. No entanto, suspeitamos que o potencial da desconstrução para reconstruir e para pensar o outro talvez seja maior do que afirmam estes autores. Como discutiremos em outra seção, a desconstrução não é uma simples estratégia de contestação do logocentrismo ocidental e da subjetividade moderna. Ela também não é uma teoria destituída da preocupação com “condições discursivas e históricas específicas", como se se tratasse de um mero jogo de abstrações. Uma leitura incompleta da desconstrução poderia, de fato, nos dar esta impressão, qual seja, a de que a desconstrução seria uma técnica de denúncia de paradoxos lógicoformais.

\section{4.}

\section{Différance, formação discursiva e genealogia}

Uma das possíveis críticas a este trabalho seria a de que a obra de Jacques Derrida não poderia ser usada para problematizar a relação entre a União Europeia e a América Latina e o Caribe ou para desnaturalizar as oposições hierárquicas que a perpassam porque o etnocentrismo do autor teria ficado explícito no discurso de 2003 sobre a necessidade de a Europa retomar seu lugar no mundo. Sustentamos que o potencial crítico da desconstrução não é afetado pela tomada de posição de Derrida porque esta é provisória, contingente. O etnocentrismo pode ser um momento, mas não é uma característica intrínseca da desconstrução.

Isto porque a desconstrução consiste em uma estratégia de leitura que prevê dois movimentos: a inversão e o deslocamento (o qual pode resultar na disseminação) das oposições hierárquicas. Na inversão, o segundo termo, hierarquicamente inferior, marginalizado e desprestigiado, é valorizado e apresentado como superior ao primeiro. No entanto, essa valorização do termo inferiorizado sofre um deslocamento. Há um deslizamento do significado do segundo termo, o que impede a cristalização deste segundo termo.

Consequentemente, o etnocentrismo não está inscrito na estrutura da desconstrução, pois ele depende da permanência da barreira, da separação entre o eu e o outro. A desconstrução realiza justamente - considerados seus dois movimentos 
- um processo de derrubada da barra de separação (/) entre os elementos inicialmente contidos numa oposição hierárquica. Reforça esta tese o fato de ela ter sido apropriada e desenvolvida por alguns representantes dos estudos pós-colonialistas, como veremos na próxima seção.

Como poderíamos interpretar esta aparente contradição na obra de Derrida? O autor mostra as sutilezas necessárias para entendermos a desconstrução. De fato, se ela se detiver no primeiro movimento, o da inversão, o risco de essencialização é grande. Temos uma "posição". Quando a desconstrução se realiza plenamente, o segundo movimento de deslocamento rompe com a essencialização inerente à inversão. Revela-se então o caráter contingente da "posição"; seu ponto nodal é desestabilizado.

É importante notar que muitas das críticas feitas a Derrida consideram apenas um dos momentos da desconstrução, como se fosse possível desmembrála. Os que consideram unicamente a fase da inversão, como Iris Young, dirão que Derrida assume uma "posição", aqui entendida como fundamento e essencialização, de defesa etnocêntrica do papel da Europa no mundo. Outros dirão que a desconstrução não permite o estabelecimento de posições, pois se preocupa apenas em destruir, mas não em reconstruir (Escobar e Bhabha enfatizam a ncessidade de reconstruir imediatamente após a desconstrução, como vimos). Entendemos que o posicionamento não está ausente em Derrida, mas também não tem caráter de fundamento. Ele é um posicionamento contingente, de acordo com a "singularidade do contexto".

Derrida deixa isto claro ao ser interrogado sobre o Estado. Em entrevista a Elisabeth Roudinesco, ele admite que:

em determinadas situações o Estado, sob sua forma atual, pode resistir a certas forças que considero mais ameaçadoras. O que chamo aqui de 'responsabilidade' é o que dita a decisão de ser aqui pelo Estado soberano, ali contra ele, pela sua desconstrução segundo a singularidade do contexto e do que se acha em jogo" (Derrida, 2004, p. 114).

Portanto, se analisarmos mais detidamente a defesa da Europa que Derrida apresenta no manifesto de 2003, contrastando-a com o unilateralismo americano, podemos dizer que ele adotou uma posição "pela Europa". Naquele contexto específico, o da invasão do Iraque, Derrida colocou-se "pela Europa", mas isto não 
quer dizer que sua posição não possa ser "contra a Europa” em outras circunstâncias.

Esta seria uma forma de explicar a convergência entre Habermas e Derrida. A exaltação da Europa por parte de Habermas está relacionada a uma leitura etnocêntrica sobre o papel da Europa, como bem apontado por Dussel. Os fatos marcantes da modernidade teriam acontecido, na visão de Habermas, na Europa do século XVIII. Em Habermas, a União Europeia representa a essência da racionalidade e da virtude. Ao contrário, no momento em que Derrida concorda com Habermas em 2003, ele está adotando uma "posição" que tem um "fundamento contingente". Ser "pela Europa" não equivale a sustentar uma essência europeia, mas apenas "resistir a certas forças mais ameaçadoras" (loc. cit.), no caso a guerra preventiva de George W. Bush. Em suma, Habermas e Derrida só podem convergir porque, provisoriamente, o último adota uma posição.

A crítica de Iris Young, portanto, seria pertinente no caso de Habermas. Há uma memorialização do passado da Europa, selecionando os "aspectos supostamente gloriosos" - silenciando sobre o colonialismo - para serem colocados no arquivo da essência europeia.

Mas esta mesma crítica não poderia ser dirigida a Derrida, uma vez que ele não compartilha da ideia de um arquivo europeu como depósito de uma verdade sobre a história da Europa. A única ressalva que poderíamos à sua posição "pela Europa" é a de que a diferença colonial permanece ausente da discussão. Na posição "pela Europa", o colonialismo europeu é obscurecido com vistas a fortalecer a virtude europeia perante os Estados Unidos. Como argumentamos, esta "posição" é provisória e a própria desconstrução poderá ser usada para apontar a persistência do colonialismo. No entanto, neste processo, ela terá de ser complementada por uma abordagem pós-colonialista.

Em certa medida, o conceito de "posição" em Derrida pode ser comparado ao de "essencialismo estratégico" de Gayatri Chakravorty Spivak. Como sugere o termo "estratégico", o essencialismo de Spivak se propõe a ser provisório; como a posição, ele traria em si a contingência.

O problema é que se torna muito difícil saber exatamente o ponto em que esses conceitos - posição e essencialismo estratégico - deixam de exercer a função provisória e contingente para a qual foram criados e passam a operar como 
suportes de uma essencialização e de um fundamento. Ou, na expressão de Ernesto Laclau, como "pontos nodais".

Na visão de Jean-Loup Amselle, o "essencialismo estratégico" de Spivak, na medida em que afirma uma alteridade radical, corre o risco de perder seu caráter estratégico e servir de instrumento para novos fundamentos. A questão é: quando a "posição" se cristaliza ? quando o essencialismo estratégico deixa de ser provisório ?

Feitas essas considerações, argumentamos que a desconstrução apresenta um caráter pós-fundacionalista que é crucial para nosso objetivo de desnaturalizar as oposições hierárquicas encontradas na relação entre a União Europeia e a América Latina.

O pós-fundacionalismo exposto pelas lógicas da diferença e da equivalência também está presente no conceito de différance de Derrida, uma das inspirações de Laclau e Mouffe. A différance sugere que o significado não é apenas resultado de uma "diferenciação" entre termos presentes no discurso, como apontava Saussure, mas também depende do fato de que cada elemento presente deve relacionar-se com algo que está ausente, "guardando em si a marca do elemento passado e já se deixando escavar pela marca do elemento futuro" (Santiago, 1976, p. 44-45). Por isso, Derrida recorre à palavra rastro (trace), querendo com isto significar que cada termo traz em si o rastro de todos os outros termos.

Segundo Derrida, “todo conceito está envolvido numa cadeia na qual ele se refere a outros conceitos, por meio de um sistemático jogo de diferenças” (1982, II). "Para que o movimento esteja presente, a presença já deve estar marcada pela diferença e pelo diferimento" (Culler, 1982, p. 110). Pensamos o presente a partir do tempo como différance. A noção de presença, portanto, é derivada, um efeito de diferenças e não uma forma absoluta do ser.

O termo différance refere-se ainda a uma alternância entre duas perspectivas: a da estrutura e a do evento. A estrutura linguística é necessária para o evento da fala, mas esta é necessária para que o sistema linguístico se estabeleça. A différance designa justamente a indecidibilidade entre estes dois momentos. Ela não é presença nem ausência, mas um jogo de diferenças.

Isto não quer dizer que o significado seja impossível. O significado dominante, elemento central na estrutura discursiva, provoca a interrupção da cadeia de significantes, num processo similar ao que Laclau e Mouffe vão descrever ao se 
referirem à constituição de "pontos nodais" na "cadeia de significantes". O trabalho da desconstrução visa a expor a arbitrariedade desse significado dominante responsável pela interrupção do fluxo da cadeia de significantes.

O ponto nodal pode se expressar na oposição filosófica, na qual não temos uma pacífica coexistência de termos contrapostos, mas uma violenta hierarquia. "Um dos termos domina o outro (axiologicamente, logicamente), ocupa a posição de comando". (Derrida, 2001, p. 56-57). Por outro lado, os pontos nodais estabelecem o fundamento ou o que Derrida chama de "metafísica da presença" que domina a filosofia ocidental. No entanto, essa busca é vã, pois, na realidade, os pontos nodais são representações discursivamente construídas que podem ser contestadas devido ao fato de apresentarem um "fundamento contingente".

$\mathrm{Na}$ hierarquia dos termos contrapostos, o primeiro termo está associado a um modelo e ao logos (a posição de comando) e o segundo à cópia ou degeneração do primeiro termo (o suplemento, a negação, a queda). O logocentrismo da filosofia ocidental supõe a prioridade do primeiro termo nas oposições hierárquicas essência/aparência, masculino/feminino, civilizado/bárbaro, pensamento/mundo, racional/irracional etc...

Como já vimos, a estratégia da desconstrução consiste em uma inversão e um deslocamento das oposições hierárquicas. Por exemplo, na oposição hierárquica masculino/feminino, o masculino é o termo hierarquicamente superior no discurso dominante. A inversão eleva o status do feminino, tornando-o hierarquicamente superior ao elemento masculino. Esta seria a posição adotada por algumas correntes do movimento feminista. O problema da inversão é que ela reifica a oposição e as identidades, deixando intacta a fronteira que separa os dois termos. Por isso, ela precisa ser complementada pelo deslocamento. No exemplo acima, o deslocamento do feminino significaria um deslizamento de seu significado, estabelecido a partir de sua oposição em relação ao masculino. O feminino "deslocado" não representaria mais uma oposição ao masculino e a própria fronteira seria diluída.

Entretanto, Derrida admite que esta situação de diluição das fronteiras das oposições hierárquicas é sempre provisória. É impossível evitar a formação de novas oposições, novas cristalizações de identidades, novas fixações de significados na cadeia de significantes. Por isso, o trabalho da desconstrução também deve ser contínuo. 
Uma outra formulação seria a de que o trabalho da desconstrução mostra como um discurso mina a filosofia que afirma ou as próprias oposições hierárquicas nas quais se baseia. Um exemplo desta estratégia pode ser verificada na reversão da oposição hierárquica de um esquema causal. A causalidade é um princípio básico do nosso pensamento; supomos que causas produzem efeitos. E mais: que a causa tem uma prioridade lógica e temporal sobre o efeito. Mas a desconstrução abala esta ordem ao realizar um intercâmbio de propriedades entre os termos. Assim, o efeito é o termo originário; é a partir dele que procuramos a causa. Ele é então a causa da causa. Produz-se aqui um deslocamento entre os termos. Como explica Culler, "se tanto a causa quanto o efeito podem ocupar a posição de origem, então a origem não é mais originária; ela perde seu privilégio metafísico" (Culler, 1982, p.102).

Em relação à nossa pesquisa, como ficará mais claro nos próximos capítulos, a relação entre União Europeia e América Latina-Caribe é muitas vezes considerada como oposição entre modelo (Europa) e cópia (América), em que o modelo seria o originário, a causa. Uma desconstrução desta narrativa histórica, no entanto, mostraria que, se a Europa "descobriu" a América, foi a "descoberta" da América que "causou” a Europa. Esta linha de raciocínio está implícita nas teorias de Dussel e Quijano sobre o papel fundamental da América na constituição da Europa.

Não se sabe então quem é causa de quem; quem é a origem. Consequentemente, não seria mais tão simples afirmar que a América é uma derivação da Europa. A desconstrução da narrativa histórica tradicional mostrará o que essa história pode ter ocultado ou silenciado (a diferença colonial ou o "escuro do presente", na formulação de Agamben) numa cadeia de significantes.

Em Laclau e Mouffe, a cadeia de significantes insere-se em uma formação discursiva, o que permite compatibilizar Jacques Derrida e Michel Foucault num mesmo marco teórico. De acordo com a definição de Foucault, só podemos afirmar a existência de uma formação discursiva quando detectamos regularidades e dispersões entre discursos elaborados em diferentes períodos históricos. A regularidade é definida por Foucault como um arcabouço que se reproduz no discurso.

A regularidade, aquilo que é constante, não está no objeto, na enunciação, nos conceitos ou nos temas. Ela não está no objeto porque não podemos falar de um objeto a priori; não está no enunciado, pois estes variam de uma época para 
outra; não está nos conceitos, pois também estes são diferentes de acordo com as épocas; e, por fim, a regularidade não está nos temas, que no caso da relação União Europeia e América Latina-Caribe são múltiplos. A regularidade encontra-se no "jogo de regras", ou seja, na lógica das práticas representacionais que acompanharam os encontros do Norte com o Sul. Foucault utiliza o termo "a priori histórico" para se referir a uma instância que funciona como condição de possibilidade do conhecimento e que se imporia como necessária. Ao contrário do a priori formal kantiano, o "a priori histórico" está sujeito à historicidade, isto é, pode transformar-se. Só que essa possibilidade de transformação não significa que ele não seja necessário durante o período de sua vigência. Em outras palavras, o "a priori histórico" parece funcionar como um ponto nodal que, durante seu período de vigência, impõe-se como a verdade de uma determinada formação discursiva. No entanto, o caráter contingente e histórico do ponto nodal permitirá uma abertura.

Desta maneira, podemos dizer que a regularidade dos discursos norteamericanos e europeus sobre a América Latina se expressa na forma de oposições hierárquicas. Os temas e termos empregados nas diferentes épocas variam, mas sempre dentro do arcabouço das oposições hierárquicas, que poderiam ser vistas como o a priori histórico.

Como vimos com Laclau, a particularidade confere à universalidade um corpo, uma encarnação. As regularidades apontadas por Foucault correspondem às oposições assimétricas. Já as dispersões irão aparecer sob formas concretas, encarnadas nas oposições cristão/não-cristão, europeu/latino, desenvolvido/em desenvolvimento, moderno/atrasado. Ou seja, o supra-histórico manifesta-se sob condições histórico-empíricas.

É justamente a estrutura repetida (o a priori histórico, que por vezes atua como supra-histórico) ao longo dos séculos que constituirá o que Foucault chamou de regularidade do discurso. Já a dimensão histórica dependerá da irrupção do acontecimento que se dá sob condições histórico-empíricas indeterminadas. Se o a priori histórico nos remete a uma abordagem estruturalista, a irrupção do acontecimento desfaz esta percepção ao introduzir a dimensão do imponderável, do acaso. É esta a leitura que Laclau e Mouffe fazem da formação discursiva em Foucault. Segundo aqueles dois autores, a possibilidade da irrupção existe devido à abertura inerente ao discurso e à disputa por um significante vazio em um momento de crise da representação. 
O surgimento do par civilizado/canibal, no contexto da "Descoberta da América", por exemplo, representa uma irrupção em relação ao par anterior cristão/não-cristão, civilizado/bárbaro. O encontro entre o europeu e os povos do continente americano provoca uma crise no quadro de referências que conferia inteligibilidade ao modo de vida europeu. Desta forma, a palavra canibal é um dos primeiros neologismos produzidos pela expansão europeia no Novo Mundo.

Também é - como diria Enrique Dussel - um dos primeiros encubrimientos do Descobrimento, um mal-entendido lingüístico, etnográfico e teratológico do discurso colombino. Mas este mal-entendido é determinante porque fornece o "significante mestre" para a alteridade colonial (Jáuregui, 2008, p. 13-14).

Em outras palavras, o "mal-entendido" proporciona o significante central, que é também o significante flutuante ou vazio. Tanto é assim que o termo canibal não conhecerá "sossego semântico" (Jáuregui, 2008). O acontecimento em torno do termo canibal sofrerá outra irrupção na luta anti-colonial, quando uma crise na representação do colonizado o leva a atribuir um outro significado ao significante canibal.

A possibilidade de irrupção do acontecimento histórico permite que identifiquemos na formação discursiva de Foucault um rico material para a crítica genealógica. A genealogia realiza uma análise diacrônica, abarcando diferentes períodos de tempo. No entanto, temos de tomar cuidado para não conceber a diacronia como uma mera sucessão de etapas ou um primeiro passo para a comparação entre épocas distintas. A genealogia constitui uma ruptura com a história linear, entendida como busca pela origem ou movimento em direção ao progresso, como vimos com Lacapra.

Por um lado, ela rompe com a ideia de uma história como procura pela origem e por uma essência atemporal. Sua tarefa será mostrar que os valores e as instituições não têm um significado universal ou intrínseco, uma origem ou uma essência, mas são produtos de um regime histórico e contingente. Por outro lado, ela se afasta da noção iluminista de progresso, como uma sucessão de eventos que se movem em direção a um telos.

Sobre a compatibilidade entre as fases arqueológica e genealógica de Foucault, entendemos que a diferença entre as duas seria mais uma questão de grau do que de natureza. É como se a genealogia levasse às últimas conseqüências e desenvol- 
vesse uma ideia já presente na arqueologia: a noção de descontinuidade. Se a arqueologia discursiva prevê continuidades e descontinuidades na formação discursiva, a genealogia vai concentrar seu foco de análise nas descontinuidades. Ela introduz mais descontinuidades do que continuidades. A História não é escrita como uma grande totalidade de "pontos monumentais", impondo uma continuidade de similaridades e analogias entre passado e presente. Ao contrário, a História caracteriza-se por rupturas, descontinuidades ou, para usar um termo que já aparece na arqueologia, pela "irrupção do acontecimento".

$\mathrm{Na}$ formação discursiva, conseguimos identificar a regularidade, a forma que se repete, mas também detectamos a irrupção do acontecimento, ou seja, os elementos novos em uma época e não em outra. A partir deste levantamento, a crítica genealógica analisará como uma determinada forma (no caso a oposição hierárquica) ganhou diferentes conteúdos e significados ao longo dos séculos.

No caso das oposições hierárquicas civilizado/bárbaro ou civilizado/canibal, a genealogia mostrará que cada um destes pares é produto de um contexto histórico e não de uma verdade absoluta. Não existe uma essência do civilizado, assim como do bárbaro ou do canibal. Estes termos só adquirem seu significado porque se inserem numa cadeia de significantes na qual cada conceito remete a outro. Além disso, a cadeia de significantes faz parte de um contexto histórico no qual um grupo tentou manter seu domínio por meio da designação de características negativas ao outro (estratégia da classificação do outro).

Para a crítica genealógica, essas dicotomias não podem ser inseridas numa história linear de progresso em que o bárbaro e o canibal ocupariam um momento anterior ao do civilizado. Este tipo de pressuposto está presente, por exemplo, no discurso de Las Casas e de Cabeza de Vaca, para quem seria possível ensinar a civilização e o cristianismo ao indígena, considerado como bárbaro ou canibal num primeiro momento.

Um dos motivos para nossa escolha desta linha de análise está relacionado à afinidade entre a genealogia e nosso propósito em relação a nosso objeto de estudo. Um genealogista está, geralmente, mais interessado no presente do que no passado. O objetivo é problematizar o presente ao construir uma contra-memória. Portanto, a genealogia questiona e historiciza discursos atuais ao traçar as relações de poder e conhecimento sob as quais esses discursos foram formados. A História é estudada como uma série de batalhas entre diferentes interpretações. 
O presente trabalho parte da identificação de uma problemática e de um discurso presentes: as representações atribuídas pela União Europeia à América Latina e o Caribe e as práticas discursivas utilizadas por estas regiões quando se referem à Europa. O contexto histórico do "descobrimento", por exemplo, interessa como contra-memória que nos permitirá problematizar e historicizar o discurso da chamada “associação estratégica” entre a União Europeia e a América Latina e o Caribe.

Poderíamos dizer que a noção de formação discursiva nos permite mapeamento as oposições hierárquicas. Já a genealogia nos leva a problematizar ou historicizar essas oposições.

Contudo, a desconstrução de Derrida também é uma estratégia válida para apontar o caráter histórico, construído e precário das oposições hierárquicas. Mas como realizar uma desconstrução que também seja uma crítica genealógica? Como conciliar estratégias de análise que não são exatamente semelhantes e às vezes até consideradas incompatíveis pela literatura pós-estruturalista?

A nosso ver, existe um reducionismo em algumas leituras da obra de Derrida que associam a desconstrução a uma mera técnica de denúncia de paradoxos lógico-formais da qual a história estaria ausente. Em "Força de Lei”, o próprio Derrida desfaz o equívoco ao esclarecer que:

\footnotetext{
Em geral, a desconstrução se pratica segundo dois estilos que, o mais das vezes, ela enxerta um no outro. Um deles assume o aspecto demonstrativo e aparentemente não-histórico dos paradoxos lógico-formais. O outro, mais histórico ou mais anamnésico, parece proceder por leituras de textos, interpretações minuciosas e genealógicas (2010, p. 40).
}

Para muitos, a relação da desconstrução com a história permanece obscura. Os historiadores tradicionais apresentam a disciplina como algo que determina o sentido, mas Derrida não pensa a história desta maneira. Por isso a acusação, que vimos acima, de que Derrida seria um textualista, negando que os contextos históricos determinem o sentido. Ao contrário, Derrida enfatiza que discurso, sentido e leitura "são históricos do começo ao fim, produzidos em processos de contextualização, descontextualização e recontextualização" (Culler, 1997, p. 148). O próprio conceito de différance pressupõe uma relação "no tempo". O sentido é um efeito não apenas das relações de um significante com outro (numa relação lógica atem- 
poral como ocorria em Saussure), mas também das relações entre um significante presente e um ausente, em um tempo entendido como diferença, diferenciação e diferimento. Portanto, Derrida enfatiza a historicidade das articulações, assim como o fato de que essa historicidade não pode ser vista como um fundamento, uma origem. Neste aspecto, a visão derridiana sobre a história se assemelha à da genealogia de Foucault. Poderíamos inclusive nos referir a uma "genealogia desconstrutiva à la Derrida e Foucault" (Glynos, Howarth, 2008, p. 15).

O que a desconstrução recusa é a "determinação histórica do sentido", ou seja, a ideia de que o sentido é determinado única e exclusivamente pelo contexto histórico. Os que adotam esta abordagem analisam os textos apenas a partir do contexto histórico no qual foram escritos, excluindo possíveis sentidos como historicamente inadequados. Derrida declara que seu ponto de partida é o de que nenhum sentido pode ser determinado fora de contexto, mas nenhum contexto conhece a saturação, ou seja, o contexto é ilimitado. Logo, o sentido está aberto a alterações quando possibilidades maiores (outros contextos) entram em jogo.

A crítica à falta de historicidade em Derrida deriva de leituras que se fixam em apenas um aspecto de sua obra, da mesma forma que determinadas interpretações sobre Foucault consideram apenas a fase arqueológica ou a genealógica. Diríamos que nem Derrida é tão textualista quanto parece à primeira vista nem Foucault é puramente genealógico. Em outras palavras, Derrida também atribui importância à história e Foucault não deixa totalmente de lado a estrutura da formação discursiva, mesmo na chamada fase genealógica.

É verdade que os trabalhos de Derrida estão interessados nas regularidades, estruturas que reaparecem em discursos de vários tipos. O que se esquece com frequiência é que a desconstrução "tem como alvo revelar a existência de articulações e fragmentações ocultas dentro de totalidades assumidamente monádicas” (De Man apud Culler, 1997, p. 283). Em outras palavras, a desconstrução aponta as fragmentações subjacentes nas regularidades, na totalidade da estrutura. Desta forma, ela demonstra um compromisso com a abertura e a descontinuidade histórica.

O mesmo equívoco ocorre em algumas leituras sobre Foucault, que destacam a genealogia como a verdadeira representante do pensamento do autor, sem considerar sua relação com a produção da fase arqueológica. Em Michel Foucault, uma Trajetória Filosófica, Hubert Dreyfus e Paul Rabinow apresentam a noção de 
arqueogenealogia para se referir a este entrelaçamento entre as duas fases de Foucault. Os críticos dessa noção argumentam que Foucault era um pensador radicalmente preocupado com as rupturas históricas e epistêmicas dos discursos e, por isto, sua obra também teria sofrido uma ruptura, da fase arqueológica para a genealógica. Sua teoria jamais poderia ser apresentada de modo linear, formando um sistema ou qualquer outro tipo de unidade.

No entanto, a nosso ver, ao utilizar a ideia de genealogia, Foucault não pretende afastar-se das análises da dita fase "arqueológica". Segundo Rafael Haddock Lobo, "as pesquisas genealógicas de Foucault seriam dedicadas não só a traçar uma arqueologia dos saberes, mas também a pensar a relação desses saberes com o poder" (2010, p. 2). Ou seja, não há sequencia entre arqueologia e genealogia, mas simultaneidade; a arqueologia está contida na genealogia.

Tanto Foucault quanto Derrida identificam regularidades ${ }^{15}$ e descontinuidades nos discursos. E a consideração por ambos da descontinuidade discursiva deriva de uma visão compartilhada sobre um conceito de história genealógica. $\mathrm{O}$ segundo "estilo" da desconstrução, menos preocupado com as regularidades, tem um caráter histórico, anamnésico e genealógico.

A ideia de uma temporalidade intempestiva (Nietzsche) é um ponto em comum entre Foucault e Derrida. Como lembra Lacapra, existe um modelo de temporalidade como deslocamento ou "repetição com mudança", vistos a partir de uma margem problemática. Este modelo, que tem sua origem em Nietzsche e Heidegger, aparece nas concepções de tempo de Foucault e Derrida. Por isso, a nosso ver, considerar a formação discursiva como estruturalista seria pouco preciso. Os deslocamentos na cadeia de significantes da formação discursiva garantem sua abertura ao novo, à irrupção do acontecimento. Há, ao mesmo tempo, repetição e mudança neste deslocamento. Para Lacapra, estaríamos lidando com variações dentro do mesmo. Ao longo do tempo, temos repetidas porém diferentes torções da "mesma" ansiedade (obviamente esta não será idêntica em todos os tempos).

\footnotetext{
15 Gérard Granel (1967) afirma que Derrida parte do postulado de Foucault de uma epistemé geral para poder sustentar a existência de "une unité profonde à l'intérieur d'une certaine époque historique”. Neste sentido, Derrida e Foucault concordariam em relação a uma unidade da epistemé. No entanto, como veremos, os dois autores vão refinar suas análises e considerar a presença de descontinuidades, rupturas e aberturas na epistemé de uma determinada época.
} 
Em relação a Foucault, devemos lembrar que esta configuração pósestruturalista da formação discursiva em nada se assemelha à formação discursiva que aparece num texto como História da Loucura. Ali, de fato, a formação discursiva tem um caráter estruturalista, na medida em que períodos dissociados são apresentados como estruturas sincrônicas e congeladas num momento do tempo. A mudança de um período para o outro não é explicada por Foucault.

Um dos poucos momentos, segundo Lacapra, em que Foucault consegue explicar a mudança ocorre na explicação do deslocamento da lepra pela loucura. Aqui temos repetição (há um lugar de exclusão e marginalização que permanece) e mudança (o objeto que ocupa este lugar muda: ora a lepra, ora a loucura). Em vez de continuidade ou ruptura, temos um deslocamento de um período para outro. Consequentemente, diz Lacapra, a fronteira entre o Renascimento e a Idade Clássica seria mais permeável e indeterminada do que supunha o próprio Foucault.

A análise de Lacapra confirma a de Hubert Dreyfus e Paul Rabinow, segundo a qual não podemos criar uma separação absoluta entre uma arqueologia, marcada pela análise do discurso e supostamente construída em termos epistemológicos estreitos, e a genealogia, que se caracteriza pela relação entre poder e conhecimento. "Aplicar uma periodização ao pensamento de Foucault é tão problemático e restritivo quanto o próprio uso que ele faz da periodização no estudo do passado (Lacapra, 2000, p. 163). O trabalho de Foucault sobre o poder e o conhecimento está pelo menos prefigurado na História da Loucura. Nesse texto, Foucault revela uma concepção de tempo como deslocamento ou "repetição com mudança” e, neste sentido, já se aproxima do modelo temporal de Derrida.

Em Posições, Derrida critica o conceito de história tradicional, baseada no sistema logocêntrico, mas propõe uma outra concepção que reforça a historicidade. Não se pode dizer que Derrida seja desfavorável à história, pois ele a usa contra a filosofia justamente para desconstruir teorias essencialistas provenientes da metafísica, afirmações a-históricas ou trans-históricas. Assim como Foucault o faz por meio da genealogia, Derrida enfatiza a historicidade de discursos que se pretendem naturais, a-históricos.

No entanto, Derrida também usa a filosofia contra a história e é esta ousadia que provoca interpretações equivocadas sobre a relação do autor com a disciplina. A história não pode ser tomada como uma autoridade privilegiada nem tam- 
pouco os arquivos a partir dos quais essa autoridade é construída. A história parte, segundo Derrida, de um "texte general" (texto geral) que não tem fronteiras. Estamos sempre interpretando esse "texto geral" e fazendo determinações de sentido que são suficientes para nossos propósitos. Mas é sempre possível apresentar outras interpretações do "texto geral" porque este fornece outras conexões e contextos. Retomando o que dissemos na seção anterior, o contexto em Derrida é ilimitado e pode abrir possibilidades novas de interpretação.

A desconstrução também detecta o que Derrida qualifica de "enxertos" nos textos, ou seja, momentos em que há uma junção ou uma sutura entre elementos contraditórios. Em outras palavras, a desconstrução expõe a heterogeneidade do texto ou, para usar um termo de Bakhtin (ver próxima seção deste capítulo), a heteroglossia de um texto, a presença de mais de uma voz num texto que se apresenta, na maior parte das vezes, como monológico, produto de uma única voz.

Quando um texto é enxertado em outro, o seu significado muda pois o contexto também é outro. Por exemplo, uma sentença de Platão num texto de Kant adquire um sentido que não possuía no próprio texto platônico. O contexto no qual a sentença é utilizada por Kant dar-lhe-á um novo sentido. O enxerto, portanto, deve ser entendido como uma intervenção na medida em que o texto enxertado muda o sentido do texto inicial.

\section{5}

\section{Bakhtin: uma abordagem dialógica sobre a história}

Nesta seção, recorreremos a Mikhail Bakhtin e seus conceitos de carnavalização, dialogismo e heteroglossia, tentando mostrar não só sua compatilidade teórica com Foucault e Derrida, mas também o potencial de sua teoria para desestabilizar pontos nodais e significados fixos.

Conforme discutido, a formação discursiva de Foucault não possui uma fronteira bem delimitada e, portanto, não está completamente separada e isolada de outras formações discursivas. Na interpretação de Laclau e Mouffe, a fronteira da formação discursiva é constantemente redesenhada à medida que a prática articulatória (cadeia de significantes) que a sustenta é confrontada com outras práticas articulatórias (outras combinações de significantes). A leitura de Laclau e Mouffe sobre a formação discursiva em Foucault nos parece apropriada porque chama a 
atenção para a dispersão dentro da formação discursiva. Longe de ser homogênea e apresentar apenas regularidades, a formação discursiva é uma unidade dividida, constitutivamente heterogênea e freqüentada pelo "outro". No interior de uma mesma formação discursiva, há vozes dissonantes que dialogam, aproximam-se e opõem-se.

Embora Bakhtin não use o termo formação discursiva, sua concepção de discurso tem semelhanças com a de Foucault. A teoria bakhtiana do dialogismo ou heteroglossia estabelece que mesmo o texto mais aparentemente monológico não é produto de um indivíduo, mas de uma interação entre interlocutores e discursos. Se a formação discursiva de Foucault é perpassada pelo outro e por vozes heterogêneas, o discurso na concepção de Bakhtin é sempre o resultado da interação de múltiplas vozes. Em ambos os casos, o enunciado do discurso não é o produto de um sujeito moderno, centrado e autônomo. Bakhtin enfatiza as restrições que controlam nosso discurso mais íntimo, como, por exemplo, a noção de "gênero de discurso" e, neste ponto, também se aproxima da concepção de sujeito de Derrida. Para Bakhtin, não somos sujeitos completamente autônomos no uso da linguagem, mas nos subordinamos a "gêneros de discurso" (speach genre) no momento em que falamos.

O discurso monológico se apresenta como o produto de uma única voz, mas uma análise mais detida mostrará a existência da polifonia por trás da monoglossia. O dialogismo pode expressar-se em textos monofônicos ou polifônicos, sendo que ele está implícito nos textos monofônicos e explícito nos polifônicos. Em outras palavras, o dialogismo é constitutivo da linguagem e, portanto, está sempre presente. Contudo, ele irá se expressar de diferentes maneiras nos textos.

A compatibilidade teórica entre Foucault e Bakhtin não pode prescindir da noção de genealogia. Embora Bakhtin não seja geralmente considerado, ao lado de Nietzsche e Foucault, como um genealogista, "ele foi fortemente influenciado pelo trabalho de Nietzsche ${ }^{16}$ e seu método é muito similar ao da crítica genealógica" (EVANS, 2001, p. 42). Um dos primeiros pontos que merecem destaque é o fato de que Nietzsche, Foucault e Bakhtin (e, conforme veremos posteriormente, também Derrida) pensam o mundo como uma arena de forças conflitantes. Sua

\footnotetext{
${ }^{16}$ James Curtis aponta que um dos principais professores de Bakhtin, Tadeusz Zielinski, era um especialista e entusiasta de Nietzsche. Ele também mostra como Bakhtin usa imagens similares às de Nietzsche.
} 
marca é mais o fluxo do que a permanência. De acordo com Evans, Bakhtin teria ido mais longe do que Nietzsche e Foucault ao especificar a forma como as forças sociais ou vozes estão ligadas umas às outras. A mistura de vozes caracterizaria o que Bakhtin chama de hibridismo, um processo semelhante ao enxerto de Derrida. Mais especificamente:

o hibridismo significa uma mistura de duas linguagens sociais dentro dos limites de um único enunciado, um encontro, dentro da arena de um enunciado, entre duas consciências linguísticas diferentes, separadas uma da outra por uma época, por diferenciação social ou por algum outro fator (Bakhtin, 1981, p. 358).

De acordo com a teoria do hibridismo de Bakhtin, o diálogo tem duas dimensões: a vertical, na qual a troca ocorre entre dois interlocutores específicos, e a lateral, na qual as linguagens sociais são formadas e reelaboradas à luz uma da outra. Na concepção bakhtiniana, cada palavra ou objeto está sobrecarregado com todas as linguagens sociais de uma sociedade. Nesta hibridização de vozes, Bakhtin revela um aspecto da heteroglossia que o aproxima da genealogia de Foucault. Vejamos. A tensão entre monoglossia e heteroglossia está presente em todos os enunciados. A monoglossia ou monologismo é o desenvolvimento de uma linguagem mestre, associada a processos sociopolíticos e culturais de centralização. Em contraste, a heteroglossia é a estratificação da linguagem em gêneros diferentes, que estão ligados a processos de diferenciação social e descentralização.

Como argumentamos, a formação discursiva não pode ser pensada separadamente da genealogia. De fato, na Arqueologia do Saber, Foucault não se refere explicitamente à relação entre saber e poder e não recorre à genealogia de Nietzsche como inspiração. No entanto, já estava implícita nesta obra sua preocupação com a questão do poder:

Durante muito tempo acreditei que aquilo de que eu corria atrás era uma espécie de análise dos saberes e dos conhecimentos. (...) Ora, não creio que esse era meu problema. Meu verdadeiro problema é aquele que, aliás, atualmente, é o problema de todo mundo: o do poder (Foucault, 1977, p. 225).

Foucault caracteriza o poder como uma "multiplicidade de relações de força" que são imanentes à esfera na qual operam e que constituem sua própria organização. Disto decorre que o poder produz sujeitos, objetos e outros elementos no domínio em que atua. Além disso, ele deve ser pensado em conjunção com a resis- 
tência, ou seja, só há poder onde há resistência. Poder e resistência estão simbioticamente relacionados; o poder requer a resistência para poder permanecer como poder.

Em relação à formação discursiva, entendemos que ela pode ser pensada em termos de saberes e poderes, embora Foucault não faça esta relação explicitamente na Arqueologia do Saber. De uma certa forma, é esta a interpretação de Laclau e Mouffe ao se referirem à formação discursiva como uma prática articulatória ligada a um determinado grupo social. Por exemplo, os neoliberais tentam apresentar como evidente a articulação entre neoliberalismo e civilização. Como vimos em outra seção, uma formação discursiva se torna hegemônica quando um grupo consegue fixar o significado do "significante flutuante". Ora, esta estratégia está diretamente relacionada à rede de saberes e poderes. Fixar o significado do significante flutuante é uma tentativa de estabelecer um regime de verdade, de fundar um saber - como, por exemplo, o do vínculo entre neoliberalismo e civilização -, ato este que não está desvinculado do exercício do poder. Ao contrário, o significante vazio ou flutuante é disputado por diferentes grupos e é desta relação de forças que resultará a fixação do significado. E é justamente por haver disputa, ou seja, resistência, que podemos afirmar a existência do poder.

Podemos dizer, lembrando Escobar, que a racionalidade ocidental e a noção de desenvolvimento dela decorrente representam uma formação discursiva hegemônica, a qual pretende expandir-se para as demais regiões do globo. Contudo, precisamos igualmente destacar que esta formação discursiva hegemônica encontra resistência por parte de outras formações discursivas, como aquela representada por comunidades indígenas, que tentaram fixar um outro significado para o significante desenvolvimento. Vimos na seção anterior que Escobar complementa o pós-estruturalismo de Foucault com uma abordagem pós-colonialista. Nesta seção, argumentamos que a teoria do dialogismo de Bakhtin pode complementar a teoria de Foucault para aproximá-la dos propósitos do pós-colonialismo. É certo que Escobar não utiliza Bakhtin em sua adaptação de Foucault, mas um de seus principais pontos, a questão da agência, pode ser pensado a partir da contribuição de Bakhtin.

Retomando a relação de Bakhtin com Foucault, podemos traçar um paralelo entre as noções de monologismo/monoglossia e dialogismo/heteroglossia e a concepção de formação discursiva como campo de poderes e saberes. 
O texto monofônico representa o predomínio de uma correlação de forças que sufoca e marginaliza outras vozes. A monofonia ocorre quando uma formação discursiva é dominada por uma única voz, quando a disputa pelo significante vazio é interrompida por uma voz que se impõe às demais e fixa um significado. No entanto, como já salientado, todos os textos são dialógicos, a única diferença residindo entre o dialogismo explícito e o implícito. Também vimos que a fixação do significado no "ponto nodal" é precária e temporária. A nosso ver, a afinidade entre a formação discursiva, entendida como rede de poderes e saberes, e o conceito de dialogismo poderia ser sustentada da seguinte forma. A monofonia ou o monologismo correspondem ao momento de fixação do ponto nodal. Mas essa fixação é precária, assim como o monologismo. Conforme citado, a tensão entre monoglossia e heteroglossia é constante.

Antecipando uma aproximação entre Bakhtin e Derrida, que desenvolveremos mais à frente, diríamos que o que temos o tempo todo é a différance, o deslizamento do significado a partir das modificações nas relações entre os termos da cadeia de significantes. Ou ainda: o que temos o tempo todo é o dialogismo, uma tentativa permanente das outras vozes de desestabilizar o ponto nodal e fixar outro significado.

O "dialogismo explícito" ocorreria num momento em que as diferentes vozes estão presentes e em oposição explícita em uma cadeia de significantes. Assim, o efeito produzido a partir da relação entre os termos do discurso é dialógico. Ao contrário, o "dialogismo implícito" existe quando os termos presentes na cadeia de significantes se relacionam com termos ausentes. No entanto, o efeito produzido por esta relação entre significantes presentes e ausentes é monológico. Por isso, dizemos que o dialogismo implícito parece monológico; embora se trate, de fato, de um dialogismo, o efeito é monológico.

Assim como ocorre com Foucault e Derrida, Bakhtin se propõe a mostrar a contingência histórica de conceitos que se apresentam como absolutos. Enquanto o monologismo tenta se apresentar como um fundamento natural, o dialogismo revela a contingência do fundamento.

Citando o caso de Rabelais, Bakhtin examina como este autor revelou a contingência das "matrizes habituais" que constituíam a formação discursiva dominante no período medieval (ou o monologismo do período). Em outras palavras, Rabelais aponta o caráter contingente e histórico das "cadeias de significantes" ou 
das "práticas articulatórias" que foram capazes de fixar o significado na Renascença. Ao mesmo tempo, o autor interfere na formação discursiva predominante ao introduzir uma nova cadeia de significantes. Se, na Idade Média, o corpo estava associado ao ascetismo e a um espaço fechado, em Rabelais ele se torna grotesco e cheio de orifícios que garantem a comunicação com o exterior.

Em suma, a formação discursiva de Foucault, entendida como rede de saberes e poderes, o deslizamento do significado na cadeia de significantes (a différance de Derrida) e a heteroglossia e o hibridismo em Bakhtin são estratégias condizentes com a crítica genealógica pois revelam o caráter histórico e contingente dos discursos.

Contudo, uma possível incompatibilidade teórica entre Derrida, Foucault e Bakhtin poderia surgir a partir do conceito de voz. Geralmente, a voz está relacionada a um sujeito, a um indivíduo, ou seja, é personalizada. Porém, há aqueles, como Evans, que consideram que o conceito de voz de Bakhtin é compatível com a ideia de anonimato presente na teoria de Foucault. Isto porque a simples referência a uma linguagem social, como faz Bakhtin, não garante que a voz seja pessoal. "Como Nietzsche e Foucault, Bakhtin oscila entre subordinar sujeitos a forças sociais e considerar os sujeitos como seres autônomos" (Evans, 2001, p. 54). No texto Discourse in the Novel, Bakhtin afirma que "o autêntico ambiente de um enunciado (...) é a heteroglossia dialogizada, anônima e social como a linguagem, mas simultaneamente concreta, preenchida com um conteúdo específico e marcada como um enunciado individual” (1981, p. 272). Neste ponto, Bakhtin também não está distante da différance de Derrida, que supõe uma indecidibilidade entre dois momentos, o da estrutura (língua) e o do evento (fala).

Percebemos ainda uma possibilidade de aproximação entre o conceito de dialogismo de Bakhtin e a questão da indecidibilidade em Derrida. Em um artigo de 1966, Julia Kristeva reconheceu a dívida do dialogismo com a dialética, mas mostrou que os dois não podem ser confundidos. Enquanto a dialética busca a síntese, o dialogismo não pode ser resolvido, o que o aproxima da noção derridiana de indecidibilidade entre os diferentes elementos de uma dicotomia.

A dialética pressupõe que os indivíduos estão numa "situação ideal de diálogo", como acredita Jürgen Habermas, e que, em algum momento, chegarão a uma síntese, a um consenso. A crença iluminista de Habermas o leva a esperar que um consenso e uma normatividade resultem da razão universalizante. Ao contrá- 
rio, tanto Bakhtin quanto Derrida sustentam que os falantes não podem entender um ao outro completamente. A continuação do diálogo depende do fato de que nenhuma das partes sabe exatamente o que a outra quer significar quando diz o que diz. Assim, o dialogismo depende da irredutibilidade de cada um dos participantes.

No entanto, o fato de Bakhtin trabalhar com o conceito de voz, polifonia e monofonia, ou seja, termos que remetem à phonè, poderia significar uma posição diametralmente oposta à de Derrida, que critica o privilégio concedido à fala em detrimento da escrita na cultura ocidental.

Para Michael Holquist, Derrida critica a oposição hierárquica entre fala e escrita, com a hipervalorização da primeira e a apresentação da escrita como uma degeneração da fala, esta sim considerada autêntica. Esta dicotomia estaria na base do fonocentrismo e logocentrismo da metafísica ocidental. A crítica de Derrida ao fonocentrismo aparece claramente no momento em que ele define seu conceito de différance, o qual só pode ser concebido na escrita. De fato, a palavra différance depende de uma substituição (a troca do "e" pelo "a") que é puramente gráfica, não acarretando nenhuma diferenciação na pronúncia da palavra. Em contraste, argumenta Holquist, Bakhtin insiste "na primazia da fala porque o que ele tem a dizer sobre os romances é incompreensível sem uma ênfase na pronúncia” (1981, p. XXI).

Em contraste, Robert Cunliffe acredita numa aproximação de Bakhtin e Derrida em relação ao grafocentrismo. Cunliffe lembra que Bakhtin considera o romance como a forma dialógica por excelência justamente porque ele depende apenas da escrita, ao contrário do teatro, que precisa da fala para completar-se enquanto obra. "Todos os outros gêneros literários, com exceção do romance, são mais antigos do que a linguagem escrita e o livro, e até os dias de hoje eles mantêm características orais" (Bakhtin, 1981, p.3). Cunliffe argumenta que Bakhtin compartilha com Derrida a "suspeita da fala" pois esta provocaria um efeito de monologização do discurso. Ambos teriam encontrado na escrita uma forma de se libertar da política e da possessividade da voz. "Derrida e Bakhtin argumentam que a "fala viva" é phoney, phoney no sentido de que distorce, nos leva a pensar erroneamente sobre o que a linguagem realmente é" (Cunliffe, 1997, p. 357).

Cunliffe chama a atenção para as sutilezas na argumentação de Derrida e Bakhtin. No primeiro, a escrita não se refere apenas às formas literais de inscrição, 
mas se expande para englobar toda a ordem dos signos. Nesse sentido, da perspectiva de Derrida, a gravação de uma voz, uma pintura ou uma tatuagem também devem ser consideradas como "escrita". A escrita é generalizável, abarca outras formas de expressão. Já Bakhtin privilegia o romance porque este é a única forma gráfica de expressão. Para Cunliffe, talvez Bakhtin seja então mais grafocêntrico do que Derrida uma vez que, para Bakhtin, a forma gráfica está restrita ao discurso do romance, enquanto para Derrida a forma gráfica se estende a todas as formas de expressão.

Mas nossa intenção não é provar ou avaliar quem é o mais grafocêntrico. Apenas pretendemos destacar que as diferenças entre Bakhtin e Derrida não são tão pronunciadas quanto querem nos fazer crer alguns autores. A nosso ver, estes dois autores têm metas e objetivos similares, como a crítica às fundações e a qualquer tipo de fechamento. A partir do exposto por Cunliffe, podemos dizer que a crítica de Bakhtin ao monologismo se assemelha à de Derrida ao fonocentrismo. Em ambos os casos, trata-se de apontar os problemas da hipervalorização da phoné.

A rejeição de Derrida e Bakhtin à primazia da phoné decorre de uma leitura crítica desses autores sobre a teoria do signo de Saussure. Em outros termos, Derrida e Bakhtin se aproximam por sua oposição a Saussure. Apesar das contribuições de Saussure para abalar a presença a si do significado, este abalo ainda é tímido. "É importante precisarmos aqui que a extensão deste mesmo abalo vai se mostrar muito mais ampla para Derrida do que pretende o próprio Saussure" (Duque-Estrada, 2002, p.19).

Derrida reconhece que Saussure aponta para a indissocialibilidade entre significado e significante, abalando desta forma a tradição metafísica. Todavia, Saussure acaba por reforçar a importância do significado ou, em outras palavras, ele considera a existência do que Derrida chamará de um significado transcendental. "A linguagem e a escrita são dois sistemas distintos de signos; o segundo existe apenas para representar o primeiro" (Saussure apud Derrida, 1976, p.30). A phoné, portanto, continua precedendo a escrita, vista como derivação ou suplemento da fala.

O monologismo se manifestaria, sobretudo, na phoné, que impõe uma interpretação monológica e autoritária. A fala teria a propensão a restringir o significado. Na linguagem de Laclau e Mouffe, a fala estanca o fluxo na cadeia de signi- 
ficantes. "Aquele que fala (...) conduz melhor seus signos; ele está ali para acentuá-los, infleti-los, retê-los ou soltá-los segundo as exigências do momento, a natureza do efeito buscado, a ocasião oferecida pelo interlocutor" (Derrida, 2005, p. 60). A fala, portanto, exerce a função de fixar o significado.

A similaridade entre Bakhtin e Derrida não se resume à crítica ao fechamento da linguagem. A estratégia utilizada por eles - respectivamente, o dialogismo e a desconstrução - para resistir a esse fechamento também é semelhante. $O$ dialogismo e a desconstrução invertem a lógica subjacente à cadeia de significantes que sustenta a formação discursiva hegemônica. Neste sentido, podemos dizer que ambas as estratégias são contra-hegemônicas.

Outro conceito de Bakhtin que se aproxima do dialogismo e da desconstrução é o de carnavalização, o qual, por sua vez, possui afinidades com o conceito de antropofagia, como veremos mais à frente. O carnaval celebra a relatividade de todas as estruturas autoritárias, invertendo a oposição hierárquica ou assimétrica imposta pelo discurso monológico. A carnavalização significa um rompimento com as formalidades da hierarquia e das diferenças herdadas pelas diferentes classes sociais, idades ou castas. Durante essas festas, a "vida saía de seus trilhos habituais, legalizados e consagrados" (Bakhtin, 1987, p.77). As mésalliances carnavalizadas revelam a arbitrariedade não apenas de convenções lingüísticas e literárias estabelecidas, mas também de toda uma gama de arranjos institucionais e papéis sociais. O carnaval nos desfamiliariza com o estado das coisas, historicizando o que era tido como imutável e eterno e revelando o caráter contingente do fundamento.

O processo de carnavalização é realizado por meio de uma inversão da oposição hierárquica, que constitui o primeiro movimento da desconstrução. Durante a festa, os pobres, oprimidos, marginalizados, destituídos se tornam as grandes estrelas, enquanto os ricos e privilegiados são relegados a uma posição subalterna. Recorrendo a Nietzsche, poderíamos dizer que há uma transvaloração. O que até então era considerado feio torna-se bonito, o que era extravagante surge como luxuoso, o brega transforma-se em belo. No entanto, a inversão carnavalesca é temporária, representa uma suspensão no tempo do cotidiano e sua reversibilidade está prevista desde o início. A subversão pode ocorrer contanto que tudo retorne ao estado de coisas anterior. 
Entendemos que a desconstrução vai além da carnavalização por propor um deslocamento do significado e não apenas uma inversão "com cláusula de reversibilidade". Apesar de instituírem novas combinações entre significantes, as mésalliances carnavalescas guardam a memória do padrão da cadeia de significantes dominante. O monologismo do discurso dominante retorna depois do dialogismo da carnavalização.

Ao contrário, a desconstrução desloca o significado que emanava da oposição hierárquica, restituindo o fluxo da cadeia de significantes ou a différance. Esta não comporta o fechamento ou a pré-determinação que um compromisso com a cadeia de significantes dominante exigiria. Como já discutido, o próprio Derrida admite a fixação do significado em alguns casos, quando é necessário tomar "posições" em relação a determinados assuntos. Em suma, o que queremos destacar é que o dialogismo, a carnavalização e a desconstrução terão sempre de se confrontar, vez ou outra, com pontos nodais, fixações de significado e monologismos.

O potencial crítico do carnaval e do dialogismo está relacionado à concepção de temporalidade a eles subjacente. Bakhtin argumenta que o mundo épico é colocado num passado heróico e mítico conectado ao início da nação. A história épica é separada do tempo presente por uma "distância épica". A temporalidade do épico é totalmente acabada e não pode ser modificada ou reinterpretada, embasando desta forma um discurso monológico. Esta concepção de temporalidade é a mesma que está subjacente à ideia de arquivo, conforme discutimos na seção sobre a concepção de história pós-fundacionalista e pós-colonialista. A idealização das origens tem sua contrapartida na projeção do futuro como catástrofe. Ora, a representação do passado como idílico e do futuro como ameaça e risco acaba por legitimar práticas autoritárias capazes de garantir um futuro idealizado ${ }^{17}$.

Ao contrário, o carnaval contesta a história oficial, monológica, o arquivo, que apresenta uma origem para a nação e uma prescrição sobre sua trajetória rumo ao progresso. Ao inverter as hierarquias, o carnaval apresenta uma reinterpretação crítica da história oficial da nação, revelando uma temporalidade intempestiva (Nietzsche). Assim como Foucault e Derrida, Bakhtin adota como estratégia de contestação uma temporalidade como deslocamento ou "repetição com mudança".

\footnotetext{
${ }^{17}$ Albert Hischman chamou a atenção para a estrutura do discurso conservador. Uma de suas manifestações é o discurso da catástrofe. Projeta-se um futuro catastrófico para justificar a adoção de determinadas políticas conservadoras.
} 
Os marginalizados, os vencidos tornam-se heróis, ao passo que os heróis da nação são associados, na cadeia de significantes, a espoliadores, falsários, aventureiros, oportunistas. A hierarquia civilizado/bárbaro é invertida e os bárbaros são reinterpretados como aqueles capazes de trazer a criação, a alegria e a experimentação a uma sociedade decadente pelo excesso de civilização. Em algumas interpretações sobre a América Latina, o canibal, por exemplo, deixa de ser uma aberração, um desvio da ordem, e se transforma na representação por excelência da resistência criativa à ordem dominante.

Neste sentido, o carnaval realiza uma suspensão da temporalidade entendida como tempo linear e ideia de progresso, tão presente na narrativa eurocêntrica sobre a modernidade. Em vez de considerar a diferença como "uma aberrração perigosa das normas da estabilidade, da segurança e da ordem" (Inayatullah, Blaney, 2004, p.2), a carnavalização provoca um deslocamento da diferença, localizando-a num espaço de liberdade e crítica ao monologismo vigente.

De uma certa forma, a carnavalização, assim como a antropofagia, permite ao latino-americano-caribenho re-significar - ou profanar - os atributos que lhe foram conferidos pelo discurso monológico europeu e nos quais os latinoamericanos-caribenhos não se reconhecem. Mas a profanação não se esgota na simples inversão; para realizar todo o seu potencial, ela deve completar o segundo movimento da desconstrução, como temos visto até aqui.

\section{6 \\ É possível compatibilizar o pós-estruturalismo com o pós- colonialismo? A Différance e a Diferonça.}

Um dos problemas com os quais nos deparamos nesta pesquisa é o da utilização de autores pós-estruturalistas considerados etnocêntricos - e de uma teorização etnocêntrica porque produzida a partir de um locus de enunciação situado na Europa - para analisar a relação entre a União Europeia e a América Latina. Como a América Latina e o Caribe poderiam afirmar sua capacidade de agência a partir de uma teoria etnocêntrica?

Aqui devemos lembrar o que Jean-Loup Amselle chama de o "paradoxo francês”. Embora estritamente europeu em sua concepção e gênese, o pós- 
estruturalismo teria potencial para universalizar-se. Seu campo de aplicação seria muito vasto, inclusive entre os autores que se autodenominam pós-coloniais. $\mathrm{O}$ sírio Aziz Al-Azmeh se alinha com Amselle pois acredita que não somos "muito diferentes" dos outros. "Os tropos e noções de pensamentos políticos e sociais hoje disponíveis formam um repertório universal. Embora 'de origem ocidental', tornou-se no último século e meio um patrimônio universal" (Al-Azmed apud Mignolo, 2010, p.118).

$\mathrm{O}$ argumento de Amselle sobre o paradoxo francês e o de Al-Azmed sobre um repertório universal são contestados por Walter Mignolo com base na diferença colonial. Para este autor, a desconstrução não consegue dar conta, sozinha, da diferença colonial. Só é possível transcender a diferença colonial da perspectiva da subalternidade e da descolonização. Mas falar da perspectiva da subalternidade significa também agir a partir de outro terreno epistemológico.

Para Mignolo, a epistemologia e o pensamento moderno têm uma origem europeia e, ao "viajarem" para a América, esbarram na diferença colonial. O ponto de chegada é sempre contaminado pela diferença colonial. É justamente por conta desta "contaminação" pela diferença colonial que é possível haver produção de conhecimento na América. É a partir do local da diferença colonial que novas epistemologias podem emergir, epistemologias que Mignolo denominará “pensamento liminar". A filosofia latino-americana de Enrique Dussel e o perspectivismo ameríndio de Viveiros de Castro, como vimos em outra seção, são exemplos de pensamentos liminares.

A ideia de pensamento liminar de Mignolo deve muito à noção de "gnose africana", desenvolvida por Valentin Mudimbe em seu estudo sobre a invenção da África. A gnose incluiria formas de conhecimento que a filosofia e a epistemologia europeia subaltenizaram nos processos imperiais coloniais.

A gnose liminar de Mignolo é um lócus dicotômico de enunciação que se situa nas fronteiras do sistema mundial colonial/moderno. Portanto, a fronteira é o lugar de um potencial epistemológico. Além de Dussel e Viveiros de Castro, outros exemplos de pensamento liminar estão presentes nas abordagens de Héle Béji e Edouard Glissant. Mignolo aproxima estes dois autores de seu pensamento liminar ao explicar que as propostas de ambos estão ligadas a uma razão pósocidental. Héle Béji sugere uma cultura mundial que resultaria do pensamento liminar e que estaria ligada a uma razão pós-ocidental. Na mesma linha, Glissant 
refere-se à possibilidade de uma cultura mundial não hegemônica. Nos dois casos, estaríamos distantes do "universalismo europeu".

Ao considerar a desconstrução, Mignolo mostra as suas limitações, o que a distinguiria do "pensamento liminar". Ela não se constituiria a partir das margens e fronteiras, mas a partir do pensamento europeu e da metafísica europeia. "Uma coisa é desconstruir a metafísica ocidental enquanto a habitamos e outra trabalhar com a descolonização como forma de desconstrução, a partir da exterioridade histórica da metafísica ocidental" (Mignolo, 2003, p. 70).

Derrida estaria situado dentro da metafísica ocidental e, portanto, não teria como empreender um movimento descolonizador que partisse da exterioridade da metafísica. O problema não seria uma desconsideração deliberada pelo colonialismo. Segundo Mignolo, Derrida está consciente dos males do colonialismo e, portanto, chega a pensá-lo como objeto de estudo. Derrida não conseguiria perceber, diz Mignolo, a diferença colonial epistemológica.

A crítica de Derrida ao logocentrismo ocidental nos deixaria ainda dentro de uma epistemologia moderna ocidental. A desconstrução nos apresenta uma crítica válida, mas que esbarra no monolinguismo. A questão da língua será fundamental para entender este ponto. A desconstrução contribui para o pensamento liminar ao não conceber a língua como instrumento neutro de uma epistemologia objetiva. No entanto, sua contribuição termina neste ponto. Ela não consegue ir além porque, apesar de não ver a língua como instrumento neutro, ela trabalha dentro do monolinguismo da cultura europeia.

Mignolo recorre a Khatibi para mostrar um exemplo de pensamento liminar que vai além do monolinguismo da desconstrução. Khatibi refere-se a um "outro pensamento", que "desloca a desconstrução da metafísica ocidental de seus limites para um esforço descolonizador. A desconstrução torna-se descolonização no espaço fraturado do bilinguismo e do bilinguajamento" (Mignolo, 2003, p.74). Khatibi pensa entre línguas, no caso, o francês e o árabe, e esta característica de seu pensamento o afastaria da desconstrução, que não apresenta este movimento de pensar a partir da fronteira, a partir do entre línguas.

A nosso ver, a antropofagia qualifica-se como uma epistemologia a partir do local geoistórico da América Latina. A Antropofagia afirmará que não somos uma cópia da Europa nem adotamos a epistemologia moderna ocidental como forma de conhecimento. Ao contrário, "nunca admitimos o nascimento da lógica 
entre nós" (Andrade, 1928). "Nunca fomos catequizados. Fizemos foi Carnaval" (loc. cit). "Contra todos os importadores de consciência enlatada. A existência palpável da vida. E a mentalidade pré-lógica para o Sr. Lévy-Bruhl estudar” (loc. cit.). E ainda: "não tivemos especulação. Mas tínhamos adivinhação" (loc. cit). O manifesto antropofágico insurge-se contra o conhecimento lógico, especulativo, racionalista europeu, mostrando que há uma forma de conhecimento antropofágico relacionada à concretude da experiência, ao Carnaval, ao hibridismo, à paródia, ao humor e à adivinhação.

Entendemos que a antropofagia é um exemplo de "desconstrução descolonizadora" ou, em outras palavras, a antropofagia é capaz de tornar complementares a desconstrução e a descolonização do saber. Ela atuaria no sentido de fazer com que as limitações da desconstrução sejam superadas pela diferença colonial e as limitações da descolonização corrigidas pela desconstrução. Vimos acima, na crítica de Mignolo, as limitações da abordagem desconstrutiva. A seguir, veremos as limitações da descolonização que poderiam ser complementadas pela desconstrução.

Uma das possibilidades de descolonizar o saber seria optar pelo pólo nãoeuropeu, mas esta decisão, a nosso ver, implicaria uma simples inversão da dicotomia europeu/não-europeu em que o segundo termo ganharia precedência e valor em relação ao primeiro. No início da modernidade, intelectuais "mestiços", como Garcilaso de la Vega, o Inca, Huaman Poma de Ayala, Santa Cruz Pachacuti Salcamayhua e Blas Valera, realizaram a inversão, defendendo o legado aborígine, a “autenticidade cultural”. O mesmo processo de inversão irá aparecer no famoso ensaio de Robert Morse, $O$ espelho de Próspero, no qual o autor hipervaloriza o latino-americano, e ainda no Ariel, de José Henrique Rodó, que defendia a herança cultural hispânica de todos os povos ibero-americanos contra o utilitarismo norteamericano.

O problema desta abordagem é que ela acaba por confirmar a "sensação de não estar de todo", do "mal-estar na dependência", do descompasso temporal entre metrópole e colônia. (ver capítulo 2). Como salientava Sérgio Buarque, a própria ênfase com que afirmamos esse antagonismo constitui uma confissão de fraqueza. Edward Said recai no mesmo problema de Rodó: a inversão pura e simples. Em Orientalismo, Said analisa a relação entre saber e poder e chega à conclusão de que o orientalismo, o saber europeu sobre o oriente, é um saber interessado, desti- 
nado a subordinar os povos do Oriente Médio. No entanto, a interpretação de Said acaba por afirmar um essencialismo simétrico e inverso, ou seja, reifica o Ocidente.

O "erro" de Rodó e Said revela os riscos de se utilizar apenas o primeiro movimento da desconstrução - a inversão - para descolonizar o saber. No caso de Said, a inversão levou a uma essencialização do Ocidente, que Mignolo denominará de "ocidentalismo". Ou seja, a inversão apenas substitui uma essencialização por outra ou repõe um fundamentalismo no lugar de outro. Para Mignolo, o Ocidente não é uma essência, mas uma construção que se iniciou no século XVI. Antes do orientalismo, tivemos ocidentalismo. Foi a subjugação do extremo ocidente (a América) que permitiu à Europa instituir-se como sujeito moderno conhecedor do Oriente (objeto) e criar o orientalismo.

Ao responder a estas críticas, Said avança com uma nova teorização que deixa de lado as essencializações sobre o Ocidente e enfatiza o hibridismo das identidades. O problema, como veremos mais à frente, é que o hibridismo, em algumas formulações, pressupõe a presença anterior de duas identidades igualmente essencializadas que vão se misturar num segundo momento.

Constatamos, portanto, que uma das limitações da descolonização do saber está na inversão e na atribuição de qualidades superiores aos povos colonizados.

Uma outra possibilidade de descolonizar o saber ocorreria se utilizássemos não só a inversão, mas também o deslocamento, ou seja, o segundo movimento da desconstrução. Este seria um exemplo de como a desconstrução poderia complementar a descolonização do saber.

Se a racionalidade europeia se baseia em dicotomias, divisões e binarismos, a escolha do pólo oposto ao europeu apenas confirmaria a "racionalidade metafísica" europeia (a inversão legitima o binarismo). Ao contrário, quando recorremos ao conceito de indecidibilidade de Derrida, estamos rompendo com aquele padrão dicotômico.

Em sua leitura sobre o modernismo, Silviano Santiago nos apresenta o operador textual do "entre lugar", que não significa um ponto médio entre dois extremos, mas um espaço relacional que não é nem cá nem lá. Ou seja, é um indecidível. O “entre-lugar" também pode ser associado ao hibridismo, desde que este não seja entendido como uma síntese dialética entre duas qualidades opostas. O "entre lu- 
gar" não é mélange de dois elementos, mas indecidibilidade, alternância constante entre dois polos.

O termo hibridismo muitas vezes pode significar o estabelecimento de uma nova essência. Porém, se o hibridismo estiver associado à indecidibilidade, não teremos como recair na tentação de lhe atribuir uma essência, já que seu movimento será sempre difuso, alternado, oscilante entre os dois pontos.

O hibridismo de Santiago é "capaz de subverter oposições categóricas e movimentos ideológicos essencialistas, bem como capaz de prover uma base para a reflexividade cultural e para a mudança" (Posso, 2008, p.112). As ideias de diferença e suplemento são fundamentais para a noção de hibridismo ou entre-lugar, que não é um ponto intermediário entre modelo e cópia.

Entre a prisão e a transgressão, entre a submissão ao código e a agressão, entre a obediência e a rebelião, entre a assimilação e a expressão - ali, nesse lugar aparentemente vazio, seu templo e seu lugar de clandestinidade, ali se realiza o ritual antropófago da literatura latino-americana (Santiago, 2000, p.26).

Na metáfora do autor, a prisão representa a cultura europeia assimilada nos trópicos, e a transgressão, o movimento de afastamento em relação a essa cultura. A transgressão está presente em Rodó, Morse e outros: uma inversão da hierarquia europeu/latino que exalta as qualidades do latino-americano. O código é a civilização europeia e a agressão, a afirmação de uma civilização tropical idílica e baseada em valores superiores. A obediência e a assimilação estão presentes na absorção de padrões europeus; já a rebelião se apresenta nos discursos nacionalistas de alguns modernistas. O antropófago da literatura latino-americana fica ENTRE um pólo e outro, ocupa um espaço VAZIO. Assim, a antropofagia é um entrelugar, nunca se fixa num dos extremos, não é nem modelo nem cópia. Logo, o hibridismo vincula-se ao entre-lugar e não a uma mistura.

A leitura pós-moderna empreendida por Silviano Santiago, portanto, se distancia da noção de "não estar de todo" e do desconforto causado por um desenraizamento. O “entre lugar” oscila constantemente de um pólo a outro. O ressentimento e o mal estar da mera inversão da hierarquia - uma das possibilidades de descolonização do saber - são substituídos por um “entre” indecidível que não se deixa apreender em fixações essencialistas. 
A partir destas considerações, pretendemos mostrar como a antropofagia, da mesma forma que "um outro pensamento" de Khatibi, se configura como uma “desconstrução descolonização" ou, em outras palavras, como ela consegue compartibilizar a desconstrução com a descolonização do saber. Porém, nem toda leitura sobre a antropofagia confirma este potencial. Podemos ter uma antropofagia que se limita à inversão e contribui para um anti-colonialismo. Ou uma antropofagia entendida como hibridismo, mistura do eu e do outro.

Certas interpretações sobre o Manifesto Antropófago de Oswald de Andrade apontam seu caráter provinciano. Desprezaríamos o europeu e nos voltaríamos para o estritamente brasileiro. Esta versão considera o manifesto como certidão de batismo de uma identidade nacional, a essencialização da identidade do brasileiro.

Na América Latina, o canibal e a antropofagia a ele vinculada também foram interpretados como afirmação de uma identidade latino-americana. O movimento anticolonialista produziu uma mudança de significado do termo canibal, invertendo a oposição hierárquica e tentando fundar o mito do bom canibal. O Caliban monstruoso e voraz de Shakespeare, por exemplo, se converteu no símbolo de identidades que tentam uma descolonização da cultura. O selvagem canibal transforma-se num símbolo de resistência, passa a ser aquele que resistiu à invasão da Conquista.

Nestes casos, a estratégia se limita a uma simples inversão. Em vez de europeizados, somos brasileiros orgulhosos de nossa identidade. Em vez de calibans inferiorizados, somos calibans fortes e resistentes, calibans-herois. Ao inverter os termos, a antropofagia reproduz o fundamentalismo da identidade: uma identidade brasileira como totalmente diferente da europeia ou uma identidade caliban, que rejeitaria tudo o que fosse europeu.

No contexto latino-americano, temos o debate entre Rodó e Roberto Fernández Retamar sobre com qual personagem da Tempestade, de Shakespeare, seríamos mais parecidos. Rodó inverte a hierarquia a partir do personagem Ariel, o habitante da ilha que, ao contrário de Caliban, aprende todas as lições ensinadas por Próspero. Ariel representaria os povos ibero-americanos, alunos dispostos a copiar e imitar o modelo de Próspero. Mas esta interpretação foi contestada por Retamar, para quem nosso símbolo não é Ariel, mas Calibán. 
Próspero (...) escravizou Calibán e lhe ensinou seu idioma para poder entender-se com ele: que outra coisa poderia fazer Calibán senão utilizar esse mesmo idioma para maldizê-lo? Não conheço outra metáfora mais acertada de nossa situação cultural (Retamar, 1930, p. 1).

No entanto, podemos fazer uma outra leitura da estratégia antropofágica de Oswald. Para Suely Rolnik, só uma leitura desatenta da antropofagia oswaldiana poderia nos levar a associá-la a uma "identidade brasileira". Ela é "um movimento que se desloca dessa busca de uma representação da cultura brasileira" (Rolnik, 1996, p.16). A antropofagia é, assim, o contrário de uma imagem identitária ou o oposto de um pensamento fundacionalista.

Giuseppe Cocco também interpreta o Manifesto Antropófago como uma crítica aos essencialismos de todo tipo. O Manifesto está próximo do perspectivismo ameríndio de Viveiros de Castro e não de teses sobre a autenticidade brasileira. "Nos parece interessante discutir a atualidade revolucionária e constituinte do Manifesto Antropófago (...) na perspectiva indicada por Viveiros de Castro, quer dizer, na perspectiva do devir-Brasil do mundo e do devir-mundo do Brasil” (Cocco, 2009, p.245).

A nosso ver, a proposta de Oswald era justamente o contrário de uma essencialização da identidade do brasileiro. A antropofagia de Oswald se aproximaria da estratégia da desconstrução. Tanto a antropofagia quanto a desconstrução desestabiliza constantemente a antítese dentro/fora. O canibal ou o antropófago não respeita as marcas que estabilizam a diferença.

O movimento anticolonialista apenas invertia os termos, representando o canibal como bom, resistente, um herói que luta contra a colonização. O conceito do Manifesto não se contenta com a inversão da oposição hierárquica cultura europeia/cultura brasileira, mas produz um deslocamento do significado de cultura brasileira.

Em diversos trechos do Manifesto, Oswald realiza enxertos em teses tradicionais sobre o que seria "o brasileiro", tentando justamente desfazer determinados mitos e idealizações. Por isso, seu discurso é fragmentado, como aponta o crítico Antonio Cândido (1977). Múltiplas vozes surgem a partir dos enxertos realizados na história oficial.

Oswald realiza, avant la lettre, a reflexão sobre a história que vimos em Lacapra. Tal como o pensamento pós-colonial de Dussel, Quijano, Coronil e ou- 
tros, a antropofagia se contapõe à narrativa moderna sobre a centralidade da Europa no mundo.

A Antropofagia de Oswald realiza uma releitura da história oficial brasileira, ou seja, do discurso monológico que apresenta uma origem e um fundamento para a história da Nação. O que se reconstroi na antropofagia é a história dos oprimidos, subalternizados, das alteridades, toda uma polifonia de vozes (enxertadas no discurso oficial) que haviam sido abafadas pelo monologismo da história linear e iluminista do "Descobrimento". A antropofagia é, portanto, uma estratégia de contestação da "ofensa" que re-significa a memória dos vencidos.

O Manifesto re-significa as origens da Nação. O Padre Vieira deixa de ser um herói para se tornar o "autor do nosso primeiro empréstimo, para ganhar comissão" (Andrade, 1928). Para piorar, "Vieira deixou o dinheiro em Portugal e nos trouxe a lábia" (loc. cit.). O padre Vieira é aqui re-significado como um oportunista e sua escrita, tida como uma das melhores da língua portuguesa, é rebaixada à categoria de "lábia". Além disso, o rei que faz o acordo com Vieira era um "rei-analfabeto" (loc. cit). Assim, os supostos fundadores da nação são resignificados como ignorantes, trapaceiros, oportunistas.

Poderíamos dizer que essa re-significação da origem está relacionada a uma crítica genealógica à visão tradicional da história do "Descobrimento". Diz Oswald: "Contra as histórias do homem que começam no Cabo Finisterra" (1928). O cabo Finisterra, localizado na Galiza, era considerado o fim da terra (Finis Terrae), no caso, o fim da Europa, para além do qual só haveria mar; a história que começa no Cabo Finisterra é a do "Descobrimento da América". Mas é contra esta história que Oswald e o movimento antropofágico se insurgem, pois havia uma história anterior à oficial, pertencente a um "mundo não datado, não rubricado. Sem Napoleão. Sem César" (1928). Aqui dois pontos merecem destaque. O mundo "não datado e não rubricado" nos remete a uma temporalidade distinta da cronológica, linear, marcada por etapas sucessivas. Por outro lado, essa história é uma história sem heróis, sendo estes aqui representados metaforicamente por Napoleão e Cesar.

A genealogia rompe ainda com a ideia de que a História é uma grande totalidade de "pontos monumentais". Também neste aspecto, a crítica de Oswald parece genealógica, uma vez que uma história sem Napoleão e Cesar significa uma história sem marcos monumentais. 
O tratamento não-linear que Oswald confere à temporalidade pode ser notado na organização do material. O autor promove uma desordem cronológica ao se referir na mesma frase à "história que começa no Cabo Finisterra", "Napoleão" e "Cesar". A história do "Descobrimento" da América, que começa no Cabo Finisterra, nada tem a ver com Napoleão e Cesar. Além disso, Cesar é anterior a Napoleão. Ao misturar as épocas históricas, Oswald provoca uma desorganização da temporalidade linear.

Esta leitura paródica da temporalidade é confirmada ao final do Manifesto, quando o autor alude ao episódio do naufrágio do navio em que viajava o bispo Sardinha, que teria sido devorado por índios. Oswald data o Manifesto no Ano 374 da deglutição do Bispo Sardinha. Embora o Manifesto tenha sido escrito em 1928, esta data é a do calendário cristão europeu. O nosso calendário e a nossa história começam, ironicamente, em 1554, quando o Bispo foi devorado.

Nesta leitura, a antropofagia de Oswald se aproxima dos autores póscolonialistas e de sua crítica sobre a narrativa história da modernidade que despreza a colonialidade. No entanto, também vemos elementos próximos da desconstrução na estratégia de Oswald.

Para o crítico Antônio Cândido, a escrita de Oswald é fragmentária, “tendendo a certas formas de obra aberta, na medida em que usa a elipse, a alusão, o corte, o espaço branco, o choque do absurdo, pressupondo tanto o elemento ausente quanto o presente" (Candido, 1977, p.78).

A descrição de Cândido sobre o estilo de Oswald tem vários pontos de contato com a noção de différance da desconstrução. Retomando a definição de Santiago, a différance não é apenas resultado de uma "diferenciação" entre termos presentes no discurso, mas da relação entre termos presentes e ausentes. O signo guarda em si a marca do elemento passado e se deixa escavar pela marca do elemento futuro, sendo que estes elementos estão ausentes.

As elipses, alusões, cortes e espaços brancos do discurso fragmentado do Manifesto Antropófago revelam justamente o movimento da re-significação proposto pela antropofagia e pela desconstrução. É por meio desses recursos linguísticos que um significado fixo presente no discurso monológico será desestabilizado e reintroduzido como significante flutuante na cadeia de significantes ou, em outras palavras, será lançado novamente no sistemático jogo de diferenças. 
A linguagem de Oswald está ancorada na sátira, na paródia, na descontextualização criativa, na estética da colagem, no humor, características que também estão presentes na definição de carnavalização de Bakhtin. O carnaval utiliza-se da paródia e da sátira para criticar o monologismo e introduzir o dialogismo.

De acordo com Jáuregui, o significante canibal realiza uma fuga vertiginosa na constelação do que Derrida denomina différance:

Os canibais evocam inicialmente os ciclopes e os cinocéfalos e depois parecem ser (...) soldados de Khan; rapidamente se convertem em índios bravos e sua localização coincide com a do buscado ouro; os canibais são definidos também como escravos ou moradores de certas ilhas. Longe de encontrar um momento de sossego semântico, o canibal desliza ao longo de um espaço não-linear: o espaço da différance colonial" (2008, p. 14).

No entanto, a resignificação na différance colonial, apresentada por Jáuregui, preserva o significado negativo de canibal. Em Oswald, num primeiro momento, podemos ver uma inversão. O canibal, que no século XVI aparecia numa cadeia de significantes ao lado de termos como selvagem, não-cristão, primitivo, criança, não-humano, surgirá no Manifesto com um significado positivo. O canibal que devora o bispo Sardinha é aquele que não se deixou catequizar, aquele que resistiu à imposição do cristianismo.

Esta “inversão" de Oswald, no entanto, não nos autoriza a concluir que ele se limita ao movimento de valorização do termo inferiorizado da oposição hierárquica europeu/canibal. A interpretação do Manifesto não pode ser feita com base num dos recortes de Oswald, mas deve levar em conta o conjunto do texto e a inter-relação entre os seus fragmentos. A "inversão" de Oswald é provisória porque será complementada pelo movimento de deslocamento que dilui a barreira entre eu e outro.

Oswald refere-se ao Visconde de Cairu como um "antropófago sagaz". "Contra a verdade dos povos missionários, definida pela sagacidade de um antropófago, o Visconde de Cairu" (Andrade, 1928). Embora haja aqui uma "inversão" - antes o antropófago era criança, imaturo, primitivo - ela é seguida por um deslocamento que anula a divisão entre o representante da história oficial (o Visconde) e o antropófago. As identidades de nobre e antropófago não podem mais ser pensadas separadamente e é este híbrido "nobre- antropófago" que se colocará contra a catequese, metáfora do saber e da filosofia europeia. 
A questão sobre como ler e interpretar o Manifesto Antropófago está ainda bastante presente no debate nacional. Em um texto sobre o Manifesto, Sergio Paulo Rouanet faz uma diferenciação entre a antropofagia caeté e a antropofagia tupinambá, que estariam em disputa no texto. A primeira seria uma antropofagia voltada para o próprio umbigo, provinciana, que exalta o ser brasileiro. Seria uma antropofagia chauvinista e preocupada com a defesa das raízes da comunidade e de uma identidade brasileira. Em nossa interpretação, os caetés são aqueles que se limitaram à inversão, devorando o outro num canibalismo chauvinista. Em contraste, os tupinambás realizam um deslocamento que leva a uma identidade aberta, nômade, híbrida, cosmopolita, provisória, em constante fluxo. São cidadãos do mundo, prontos para realizar uma antropofagia desconstrutora de identidades fixas.

No texto, Rouanet "psicografa" Oswald e mostra que o modernista teria deixado de ser um antropófago caeté para se tornar um antropófago tupinambá. Em suma, Oswald mandaria um recado, por meio de Rouanet, de que mudou de opinião sobre a antropofagia. A nosso ver, a "carta psicografada" de Oswald não seria necessária pois, desde o início, é possível ler o Manifesto numa “chave tupinambá".

Numa leitura bakhtiniana, o caeté é o defensor do monologismo; mesmo quando absorve o outro, só o faz em seus próprios termos, mantendo o predomínio de sua voz. Ao contrário, o tupinambá introduz o dialogismo, o hibridismo, realizando uma antropofagia da indecidibilidade, em que a identidade oscila entre uma raiz tupinambá e uma identidade estrangeira.

A interpretação de Rouanet é compartilhada pelo escritor e diplomata João Almino. "a cultura brasileira não é (...) insular e voltada unicamente para suas raízes, para o solo nacional (...) nem, por outro lado, se insere de forma secundária ou subordinada, numa civilização universal centrada na Europa" (Almino, 2011, p. 55).

Não podemos negar que o Manifesto Antropófago faz uma crítica ao cosmopolitismo eurocêntrico predominante na cultura brasileira do final do século XIX e início do XX, mas esta atitude corresponderia apenas à fase da inversão da desconstrução, o momento em que se assume uma "posição" contrária ao polo inicialmente dominante da oposição hierárquica. Digamos que é o momento em que se substitui um monologismo por outro, uma identidade fixa por outra. 
Mas o Manifesto não para por aí. Não há, diz Almino, uma opção pelo primitivo em prejuízo do civilizado/cosmopolita/eurocêntrico. A nosso ver, não há opção pelo primitivo simplesmente porque a dicotomia civilizado/primitivo é desfeita no deslocamento. O primitivo de Oswald é, ao mesmo tempo, moderno, civilizado, tecnologizado, daí a imagem do híbrido "bárbaro- tecnizado" presente no Manifesto. A semelhança da antropofagia com a desconstrução torna-se clara nesta diluição da dicotomia. Não há superioridade do civilizado sobre o primitivo nem deste sobre aquele. O que ocorre é uma troca mútua de propriedades entre primitivo e civilizado.

A cultura brasileira deixa de ser pensada como oposta à europeia e se torna híbrida. "Nunca admitimos o nascimento da lógica entre nós (...) Nunca fomos catequizados. (...) Fizemos Cristo nascer na Bahia. Ou em Belém do Pará (...) Nunca fomos catequizados. Fizemos foi Carnaval" (Andrade, 1928, p. 1). De fato, o carnaval, como vimos com Bakhtin ${ }^{18}$, subverte a lógica das oposições hieráquicas e produz hibridismo.

O enxerto e o hibridismo que percebemos no texto de Oswald nada mais são do que resultado de uma antropofagia que se mantém entre duas linguagens ou entre duas consciências linguísticas diferentes, sem criar uma síntese entre elas. Este hibridismo se assemelha ao entre-lugar (Santiago) e ao indecidível (Derrida).

Dessa forma, o discurso latino-americano é marcado pela indecidibilidade; ele emerge entre o código europeu (modelo) e a transgressão (a cópia). Este discurso não é um termo de uma relação, mas é a própria relação. O discurso latinoamericano nunca é posicionado, ou melhor, é "provisoriamente" posicionado se lembrarmos que todo ponto nodal ou toda posição tem um caráter contingente. Como parte de um ritual antropofágico, ele transforma os dois polos, no caso em estudo, a União Europeia e a América Latina e o Caribe.

O entre-lugar mostra que o já constituído (as entidades Europa e América Latina e Caribe) nunca foi o que nós pensávamos que era, pois a América Latina não é apenas um suplemento da Europa, mas a ultrapassa. Em vez de mera cópia e suplemento, a América Latina "transforma e deforma" o que é europeu, criando sua própria originalidade.

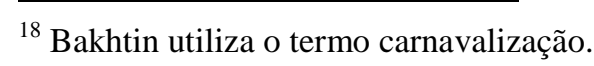


O par transforma/deforma foi apresentado por João Cruz Costa na obra Contribuição à História das Ideias no Brasil, de 1956:

Certos autores, muito ciosos de originalidade, costumam denunciar a imitação como a fonte dos nossos defeitos e erros. É mister, porém, não esquecer que a imitação é um fenômeno social natural e universal. Nossa terra não possui o monopólio da imitação. Aliás, esta, como escreve Adrien Delpech, não vai sem deformação, o que já constitui uma originalidade. (apud Santiago, 2006, p. 196).

No entanto, é a própria noção de originalidade que é posta em questão no processo da cópia e da deformação. Na interpretação clássica, o modelo é original e autêntico (a Europa) e a cópia, uma reprodução fiel e não-original (a América Latina). Mas, se a cópia for infiel, ou seja, se ela deformar o original, teremos então a criação de uma obra original. E, talvez, como afirma o personagem principal do filme Cópia Fiel, de Abbas Kiarostami, a cópia tenha tanta qualidade quanto o original. Na formulação de Derrida, é a cópia que confirma o original. Sem a imitação não sabemos como identificar o original, o modelo, o clássico.

No Manifesto da Poesia Pau-Brasil, Oswald também re-significa a cópia ao exclamar: "contra a cópia, pela invenção e pela surpresa" (2011, p. 24). Poderíamos interpretar esta passagem da seguinte forma: contra a cópia que imita, a favor da cópia que inventa ao deformar o que copiou.

Augusto de Campos apontará o Manifesto Antropofágico como o texto referencial para a análise de nossa cultura por ser "a única filosofia original brasileira":

Ela não envolve uma submissão (uma catequese), mas uma transculturação: melhor ainda uma 'transvaloração': uma visão crítica da história como função negativa (no sentido de Nietzsche), capaz tanto de uma apropriação, como de desapropriação, desierarquização, desconstrução (Campos, 1992, p. 233).

Em suma, a antropofagia de Oswald seria uma espécie de pensamento liminar, de um outro pensamento ou, ainda, de uma filosofia feita a partir da América Latina, como queria Dussel. O Manifesto Antropofágico realiza um processo de descolonização da desconstrução. A frase "Tupi, or not tupi that is the question" repete a estrutura da frase de Hamlet, mas em vez do suposto universalismo 
do "Ser ou não ser", Oswald mostra que há uma especificidade cultural em "Tupi ou não tupi”. Esta é a nossa questão, a questão do colonizado e não uma especulação metafísica sobre o ser.

Nossos problemas não são os mesmos dos europeus, aponta Oswald. Ao contrário dos relatos da literatura europeia do século XX sobre a desconstrução do sujeito moderno, na literatura latino-americana o sujeito está marcado, desde o início, pelo fracasso. Um protagonista de Beckett conserva a consistência discursiva de um ex-sujeito cartesiano transcendental. Já o protagonista de um romance latino-americano não tem a mais remota experiência do sujeito cartesiano.

Processo semelhante está presente no conceito de "diferonça" de Viveiros de Castro. Em Oswald, o "ser ou não ser" hamletiano é transformado no "tupi or not tupi"; em Viveiros de Castro, a différance de Derrida emerge como diferonça. Nos dois casos, a lógica da filosofia europeia não é descartada de imediato, mas transgredida, deformada, resultando numa reflexão que se posiciona na margem, como pensamento liminar. 


\section{4. \\ O Posicionamento da União Europeia e da América Latina no século XXI: as declarações de cúpula}

\subsection{A Declaração como gênero de discurso}

Conforme antecipado no capítulo 1, as seis declarações de cúpula entre a União Europeia e a América Latina e o Caribe tentam construir uma determinada visão de mundo que corrobora a leitura tradicional sobre a natureza do sistema internacional. Este é apresentado como um lugar perigoso, onde impera a anarquia entre os Estados e de onde provêm as ameaças. As declarações reproduzem o “discurso sobre a problemática da anarquia" (Ashley, 1988) nas relações internacionais, apresentando-o como uma justificativa para a criação da associação estratégica.

Uma das principais características desse discurso - e que será incorporada pelas cúpulas - é a naturalização da anarquia. Esta é considerada como o fundamento do internacional, um elemento que estaria sempre presente, ou melhor, que seria a própria matéria da qual o internacional é feito. O trabalho de Ashley e de outros autores pós-estruturalistas nas relações internacionais será o de mostrar a anarquia como uma construção política arbitrária e explicitar a forma como ela é construída pelas práticas discursivas presentes na disciplina. A chamada "prática heroica" (Ashley, 1988) é uma tentativa constante de reafirmar, por meio da repetição, o caráter natural da anarquia.

As declarações de cúpula realizam dois processos de naturalização: o da anarquia, seguindo a tradição nas relações internacionais, e o das relações entre a União Europeia e a América Latina. Podemos dizer que tanto o outside (anarquia) quanto o inside (UE-ALC) da associação estratégica são naturalizados, compreendidos como evidentes em si mesmos. A primeira naturalização se baseia numa longa prática discursiva das relações internacionais, como mostrou Ashley; já a segunda recorre a relações históricas que, de tão remotas, justificariam a naturalização das relações entre a União Europeia e a América Latina e o Caribe. Quaquer possível cooperação entre estas duas regiões é vista como uma decorrência lógica e "natural" da história. 
As declarações constroem o mundo exterior como uma ameaça, um lugar de desordem e anarquia, justificando assim a criação de uma associação birregional capaz de garantir a ordem. Listamos abaixo os termos que aparecem nas seis declarações de cúpula e que podem ser considerados como sinônimos de ordem e desordem:

\section{Ordem}

Integração

Democracia

Direitos humanos

Segurança

Estado de direito

Liberdade individual

Boa governança

Estabilidade política

Progresso

Justiça

Coesão social

Accountability

crescimento econômico

paz international

respeito pela soberania

Desenvolvimento sustentável

Igualdade social

Sistema multilateral

Prevenção

integridade territorial

estabilidade macroeconômica

liberalização comercial

meio ambiente

não-intervenção

autodeterminação

\section{Desordem}

globalização

discriminação

racismo

xenofobia

corrupção

armas de destruição em massa

migração ilegal

mudanças

pobreza

tráfico ilícito de armas

terrorismo

crime organizado

drogas

assimetrias

furacões

mudança climática

exclusão

desigualdade

vulnerabilidade

desastre natural

desafios

fluxos financeiros voláteis

coerção

uso da força 
Não há correspondência entre os termos que aparecem na coluna da esquerda e da direita. Optamos por esta disposição porque, muitas vezes, um termo da coluna da "ordem" se opõe a mais de um da coluna da "desordem". As listas nos permitem visualizar os diversos elementos que são considerados como parte da anarquia do sistema internacional e que demandam uma reação da associação estratégica, que defenderá todos os valores localizados à esquerda do quadro. A integração, por exemplo, é considerada uma forma de enfrentar um processo de globalização que traz consigo assimetrias, exclusão, desigualdade, vulnerabilidade e fluxos financeiros voláteis. Ou então poderíamos dizer que a democracia, tal como prevista no espaço birregional da associação estratégica, é capaz de se contrapor ao uso da força, da coerção.

Da mesma forma, o Estado de direito, a boa governança, a estabilidade política e os direitos humanos são armas poderosas contra a discriminação, o racismo e a xenofobia. No caso dos furacões e desastres naturais, a associação estratégica ficaria encarregada de criar políticas destinadas à preservação ambiental e à prevenção de catástrofes. E, claro, a associação seria um espaço de progresso e justiça para aqueles que dele participarem, em contraste com o "mundo exterior" onde grassa a pobreza e a desigualdade econômica e social.

Uma análise do quadro acima exposto revela que a associação estratégica entre União Europeia e América Latina é discursivamente construída como moralmente superior ao outside anárquico. Haveria, assim, um desnivelamento moral entre o inside e o outside, configurando uma oposição hierárquica. Um dos objetivos desta tese é apontar, com base na estratégia desconstrutiva de Derrida, como o discurso sobre a associação estratégica mina as próprias oposições hierárquicas nas quais se baseia.

A proposta de uma associação birregional com base na percepção da ameaça pressupõe que a anarquia surgiu primeiro e que a associação entre a União Europeia e a América Latina é apenas uma forma de reagir à anarquia. Teríamos então a anarquia como causa e a associação estratégica como sua consequência. Se analisarmos, entretanto, as duas colunas de palavras que correspondem à ordem e à desordem, veremos que nem sempre o que faz parte da associação estratégica (coluna da esquerda, ordem) é uma reação a fatos da coluna da direita. Ao contrário, é possível encontrar casos em que elementos atribuídos à associação estratégi- 
ca e, por isso, considerados moralmente superiores, são a causa de eventos listados na coluna da direita.

Os documentos, por exemplo, defendem a liberalização comercial do espaço birregional, ou seja, cria-se uma oposição hierárquica entre liberalização e protecionismo, na qual o segundo termo é moralmente condenável. No entanto, os documentos também consideram os fluxos financeiros voláteis - sobretudo após a crise econômica de 2008 - como um elemento da desordem. Assim, omite-se o fato de que é a liberalização comercial (ordem) a responsável por fluxos financeiros voláteis (desordem). Inverte-se assim a causalidade pressuposta pelo discurso da associação estratégica, de que a ordem é uma reação à desordem, à anarquia e à ameaça do mundo exterior. Na questão dos fluxos financeiros, percebemos que é a ordem da "liberalização" que causa ou, pelo menos, propicia a desordem da desregulamentação excessiva.

O mesmo pode ser dito se pensarmos na oposição hierárquica entre progresso/crescimento econômico, por um lado, e pobreza/desigualdade, por outro. Há quem defenda, como consta nas declarações de cúpula, que o progresso e o crescimento são instrumentos inequívocos de combate à pobreza e à desigualdade. Mas parece que este não é um ponto de vista amplamente compartilhado. Sem aprofundar uma discussão sobre crescimento e desigualdade, que fugiria aos propósitos deste trabalho, poderíamos lembrar a existência de uma literatura empenhada em mostrar que progresso e crescimento geram desigualdade e pobreza. Em vez de solução para a pobreza, eles seriam seus financiadores.

Um último exemplo de oposição hierárquica que não resiste à estratégia desconstrutiva é aquela que pode ser estabelecida entre segurança e migração ilegal. Entende-se comumente que a migração ilegal, sinônimo de desordem, é um problema que deve ser combatido com medidas de segurança. Contrapõe-se assim a ordem à desordem, sendo que a primeira é uma reação à segunda. A desordem desencadeia (causa) medidas de ordem. No entanto, o que torna a migração "ilegal" é justamente o controle de fronteira, a tentativa de estabelecer uma separação estrita entre o inside e o outside. Portanto, é a ordem do Estado que cria a ilegalidade da migração e não o contrário.

O discurso de uma associação estratégica provedora de uma nova ordem mundial marcada por qualidades encontra ainda seus limites na noção de "outside constitutivo" (Derrida, Walker, 2010). Pode-se falar no espaço birregional porque 
existe um "outside constitutivo", formado pelos elementos da "coluna da desordem". Esse outside é mesmo visto como a garantia da existência e da especificidade da associação.

Mas, como discutido no capítulo 2, se o objetivo da associação estratégica é dar o exemplo de como proceder no cenário internacional, então supõe-se - e espera-se - que outros Estados sigam o mesmo caminho. Revela-se então o paradoxo do projeto e a impossibilidade de a associação estratégica alcançar o que promete. Caso todos os Estados adotem os valores da ordem (coluna 1), de que forma ainda poderemos falar de um "outside constitutivo"? O espaço da ordem não pode se estender e abarcar todo o globo pois isto acarretaria a ausência de um “outside constitutivo", que, na verdade, é a condição de possibilidade para o espaço birregional. Temos, portanto, um discurso que mina o próprio projeto que pretendia sustentar. A ideia de um crescimento espontâneo e natural da associação estratégica é vedada pela necessidade de um "outside constitutivo", que nos obriga a desnaturalizar aquilo que considerávamos como dado.

Em seu estudo sobre as Declarações de Independência, David Armitage notou a tentativa de naturalização empreendida pelo texto. No caso das declarações das cúpulas, estamos trabalhando com um documento sem qualquer relação com processos de independência. Ainda assim, existem alguns pontos do argumento de Armitage que podem detectados nas declarações de cúpulas, como o processo de naturalização.

Na declaração de independência dos Estados Unidos, por exemplo, considera-se a existência de "verdades evidentes por si mesmas". Nesse sentido, o documento não cria nada de novo, mas apenas expressa algo que já fazia parte do mundo, confirmando sua legitimidade. As seis declarações de cúpula seguem, de uma certa forma, este padrão pois pretendem confirmar relações entre a União Europeia e a América Latina que seriam já naturais em si mesmas. Os documentos das cúpulas só irão reiterar e formalizar algo "evidente em si mesmo": a proximidade de valores entre a União Europeia e a América Latina.

As declarações, sejam ou não de independência, dirigem-se sempre aos outros, como lembra Derrida. Por esta razão, elas costumam ter uma estrutura semelhante. Geralmente, são iniciadas por pronomes da primeira pessoa, como "nós". Um outro aspecto recorrente das declarações está no seu caráter performa- 
tivo ${ }^{19}$, ou seja, na possibilidade de realizarem o ato a que se referem. Uma declaração de independência realiza o ato de independência, assim como uma declaração de associação estratégica inaugura a associação.

Mas, ressalta Derrida, neste processo performativo, o "nós" exclui aqueles que não tomaram parte na elaboração da norma. O "nós" da declaração americana, por exemplo, não inclui os negros e os índios. Assim, a declaração de independência americana só aparentemente fala em nome do povo porque, na verdade, este é criado pelo próprio ato performativo. Ele não existia antes da declaração de independência.

Todos os textos das declarações de cúpula trazem o pronome "nós" ou verbos conjugados na primeira pessoa do plural com o pronome oculto. Do começo ao fim de cada declaração, o "nós", implícito ou explícito, aparece em quase todas as frases, em referência aos chefes de Estado e de governo da União Europeia e da América Latina-Caribe que assinaram o documento. O "nós" das declarações de cúpula exclui, portanto, os povos dos países signatários. Por outro lado, pressupõe-se um consenso e uma comunidade entre aqueles que se identificam como "nós". Haveria uma unidade de propósitos entre os chefes de Estado e de governo da UE e da América Latina-Caribe ao criarem a associação estratégica.

Uma análise das declarações mostrará que esse consenso é criado pelo pronome "nós", que, mesmo oculto na maioria das frases, cria um efeito monológico no texto. Ele parece ser uma tentativa de criar um "sentimento do nós", uma "comunidade imaginada" (Anderson, 2008) baseada nos mesmos valores históricos e culturais. Assim, temos a impressão de que apenas uma voz consensual faz a declaração: a voz da comunidade União Europeia-América Latina-Caribe. "Nós, os Chefes de Estado e de Governo da União Europeia e da América Latina e Caraíbas” (...) (Madri, 2010, p.1). “Comprometemo-nos a reforçar o nosso diálogo" (loc. cit.). "Tomaremos medidas para erradicar a corrupção e para promover a ética e a transparência nas atividades governamentais e do setor privado" (Guadalajara, 2004, p.10).

As declarações, ao utilizarem o pronome "nós" ou "eu" (sempre a primeira pessoa, do plural ou do singular), acabam produzindo um efeito monológico, que muitas vezes esconde o dialogismo ou heteroglossia presente em qualquer discur-

19 Austin distingue entre enunciados constativos e performativos. Os primeiros descrevem um estado de coisas e podem ser verdadeiros ou falsos. Os segundos realizam a ação a que se referem. 
so. Neste sentido, elas também tentam fixar um significado para o significante flutuante de uma determinada época, criando um ponto nodal. No caso das declarações de cúpula, o ponto nodal que se tenta estabelecer é o de que a associação estratégica entre União Europeia e América Latina-Caribe representa um consenso entre as regiões ou de que os interesses de ambas as partes são convergentes.

Documentos como declarações também costumam ser impositivos. Segundo Barbara Jonstone, uma forma de naturalizar o mundo é usar estruturas sintáticas que denotam certeza. A declaração de independência americana inicia-se com uma reivindicação de completa certeza, que é assegurada pelo verbo "ser" e outros conjugados no presente do indicativo, como grifado abaixo:

\begin{abstract}
Nós, por conseguinte, representantes dos Estados Unidos da América, (...), publicamos e declaramos solenemente: que estas colônias unidas são e de direito têm de ser Estados livres e independentes, que estão desoneradas de qualquer vassalagem para com a Coroa britânica, e que todo vínculo político entre elas e a GrãBretanha está e deve ficar totalmente dissolvido (Carta de Independência dos Estados Unidos, 1776).
\end{abstract}

Já na declaração de Madri de 2010, encontramos o verbo reiterar conjugado no presente do indicativo: "reiteramos" aparece nove vezes no texto. A nosso ver, reiterar poderia ser incluído no conjunto daqueles verbos que Jonstone chama de formas epistêmicas indicadoras de certeza e desencorajadoras do debate: "ser", "saber", "afirmar" e "pensar". Se considerarmos que re-iterar quer dizer afirmar novamente, repetir o que já foi dito, então o seu caráter epistêmico de "produtor de certeza" é multiplicado. A declaração de Madri não apenas afirma; ela re-itera o que já foi estabelecido nos documentos das cúpulas anteriores. Destacamos alguns exemplos retirados da Declaração de Madri: "Reiteramos o nosso empenhamento no multilateralismo, principalmente no âmbito do sistema das Nações Unidas"." Reiteramos o nosso apoio ao desarmamento e à não-proliferação nucleares". "Reiteramos o nosso empenhamento nos objectivos e princípios consagrados na Carta das Nações Unidas". "Reiteramos também a nossa decisão de apoiar todos os esforços desenvolvidos no sentido de defender a igualdade soberana de todos os Estados" (Madri, 2010).

Como visto no capítulo introdutório, a declaração de cúpula mais recente precisa reiterar e reafirmar o que foi dito nas anteriores, pois, a existência da asso- 
ciação estratégica depende desse ato de repetição. A reapresentação dos propósitos da associação estratégica expõe o seu caráter anti-fundacionalista. Se a associação tivesse sido fundada de uma vez por todas em 1999, não haveria a necessidade da reiteração. Por mais que o discurso das cúpulas tente realizar um processo de naturalização da associação estratégica entre União Europeia e América Latina-Caribe, a própria reiteração do projeto revela seu caráter contingente.

Uma comunidade birregional União Europeia-América Latina-Caribe não deixa de ser, portanto, uma "comunidade imaginada", que precisa ser refundada a todo momento. Não há um ser ontológico "União Europeia-América Latina-Caribe" desconectado das práticas que constituem essa realidade e uma dessas práticas é justamente a cúpula realizada a cada dois anos.

Em suma, as declarações se caracterizam pela utilização repetitiva do pronome na primeira pessoa, por afirmações categóricas, pela conjugação dos verbos ser, saber, afirmar, reiterar e acreditar, entre outros. Tanto o pronome "nós" quanto esses verbos conjugados no presente do indicativo conferem à declaração um efeito monológico. O pronome "nós", como vimos, parece referir-se a uma única voz. $\mathrm{E}$ os verbos citados introduzem afirmações contundentes que desestimulam a contestação. Além disso, as declarações tem um viés performativo bastante acentuado pois estabelecem uma agenda e, ao fazê-lo, comprometem-se com sua execução. $\mathrm{O}$ ato performativo gera, por si próprio, uma ação, nem que seja a de prometer algo.

A partir do exposto, poderíamos perguntar: não constituem as declarações um "gênero de discurso", tal como definido por Mikhail Bakhtin? De acordo com o autor, "cada sentença é individual (...), mas cada esfera na qual a linguagem é usada desenvolve seus próprios tipos relativamente estáveis de sentenças" (Bahktin, 2007, p. 60). Como discutido no capítulo teórico, Bakhtin se afasta dos dois polos apontados por Saussure: língua e fala. Nenhuma sentença é completamente original porque estamos submetidos aos gêneros de discurso.

Os gêneros de discurso seriam, segundo Bakhtin, muito diversos devido às imensas possibilidades da atividade humana. Cada esfera de atividade ${ }^{20}$ contém

\footnotetext{
${ }^{20}$ A ideia de uma esfera de atividade que produz gêneros de discurso lembra a noção de campo de Pierre Bourdieu. Uma aproximação entre Bakhtin e Bourdieu foi realizada por Sheila Vieira de Camargo Grillo.
} 
todo um repertório de gêneros de discurso que "crescem à medida que uma esfera particular se desenvolve e se torna mais complexa" (loc. cit.). Os gêneros de discurso podem incluir diálogos cotidianos, padrões de comando (como no caso dos militares), padrões utilizados em documentos de negócios, padrões de afirmação científica, gêneros literários, linguagem jurídica etc...

O comando militar, por exemplo, destaca-se pelo uso dos verbos no imperativo, enquanto o discurso científico costuma empregar os verbos no infinitivo. Johnstone destaca que os escritos científicos se distinguem de outros tipos por alguns elementos, como agência e transitividade. A eliminação dos agentes pela voz passiva é uma forma de o escritor reforçar a impressão de que atividades científicas são objetivas, independentemente de quem as pratique. Esta formulação parte de uma perspectiva positivista sobre a ciência, negando a ingerência da observação do sujeito sobre o objeto estudado.

A declaração dos Estados Unidos e as das Cúpulas apresentam estruturas e características em comum, como o pronome na primeira pessoa do singular ou do plural e os verbos no presente do indicativo. Mas as declarações também apresentam por vezes pontos semelhantes ao dos discursos científicos, como a eliminação da agência na estrutura da frase. A Declaração do Rio (1999), por exemplo, é escrita na terceira pessoa e de um ponto de vista supostamente neutro. A impessoalidade da terceira pessoa é reforçada na frase seguinte pelo uso da voz passiva: “Entre as decisões tomadas na Cúpula ....”.

Os Manifestos seriam também um gênero de discurso que trabalha com verbos no presente do indicativo e, sobretudo, no imperativo. Desta forma, eles teriam uma tendência ao discurso monológico, excluindo de sua argumentação qualquer traço de vozes dissonantes. As ideias de um manifesto são geralmente apresentadas como verdades absolutas, inquestionáveis. De acordo com Hans Ulrich Gumbrecht:

manisfestos nos colocam face a face com as intenções e, no pior dos casos, até com as introspecções de estranhos, sem dar nenhuma liberdade para a nossa imaginação (...). O que devemos então fazer com a energia excessiva dos escritores de manifestos que, em vez de deixar as suas intenções implícitas e fazer com que os seus leitores participem do jogo da interpretação, bradam as suas intenções para todos? (2011, p. 289). 
Ou seja, Gumbrecht está nos dizendo que os manifestos - incluindo o Manifesto Antropófago de Oswald - são monológicos, contribuindo para sufocar possíveis vozes críticas. Segundo ele, a "energia excessiva” concentrada numa posição teria o efeito de afastar eventuais oposições. A partir dos argumentos e da discussão realizados no capítulo 3, podemos constatar exatamente o contrário do que afirma Gumbrecht. O Manifesto Antropofágico rompe com a rigidez típica dos manifestos em geral e promove hibridismos e polifonias. Os enxertos introduzidos pelo Manifesto criticam a história monológica oficial e profanam o arquivo.

\section{2 \\ Polifonia e Intertextualidade}

Na seção anterior, destacamos que a utilização do pronome "nós" produz uma representação sobre uma comunidade entre a União Europeia e a América Latina-Caribe. Além disso, o pronome "nós" confere um caráter monológico ao discurso, fixando um ponto nodal. A seguir, veremos que o monologismo do discurso das cúpulas é apenas aparente porque, como mostrou Bakhtin, todo discurso é dialógico, ainda que muitas vezes a polifonia esteja implícita. O monologismo corresponde a um momento de fixação do ponto nodal (o "nós" da comunidade), mas ele próprio é precário, podendo ser contestado por outras vozes.

Em textos acadêmicos, é comum encontrar a polifonia explícita, pois geralmente o autor do texto cita e faz referências constantes a outros pensadores, com os quais concorda ou discorda. Em consequência, as vozes dos outros (ou os enxertos, para usar o termo de Derrida) aparecem explicitamente no texto. Ao contrário, nas declarações, nos deparamos com outro tipo de estrutura. A declaração não argumenta diretamente contra alguém, mas comunica ao mundo o seu ponto de vista. Entretanto, ao fazê-lo, está indiretamente se contrapondo a outras opiniões.

O dialogismo implícito no texto das declarações aparece de diversas formas. Por um lado, existe um "Outro ausente", os Estados Unidos, contra o qual a comunidade União Europeia-América Latina-Caribe cria sua identidade. É como se o texto das declarações conversasse e argumentasse com alguns documentos produzidos pelo governo americano. Por outro lado, é possível notar que, em alguns momentos, a União Europeia se refere à América Latina como um “outro", 
cindindo desta forma a comunhão de propósitos que poderia existir entre as duas regiões. Em vez de uma única voz monologizante, expressa pelo pronome "nós", temos a "voz" da União Europeia e a da América Latina e do Caribe. A voz dissonante da América Latina e do Caribe fratura a "comunidade imaginada" criada pela utilização exaustiva do pronome "nós".

Na primeira declaração de Madrid, de 2002, temos um exemplo de polifonia implícita. Um dos objetivos da cúpula é "Reforçar o sistema multilateral com base nos objectivos e nos princípios da Carta das Nações Unidas e do direito internacional (Madri, 2002, p.1). O texto não faz referência àqueles que poderiam pensar de outra maneira e é por isto que podemos dizer que a polifonia está implícita. Se estivéssemos lidando com um texto acadêmico argumentativo, a citação do pensamento contrário ao que está sendo exposto seria muito mais provável. Mas o texto da declaração parece seguir uma única direção e não se referir diretamente a quem pensa diferente.

No entanto, se considerarmos o contexto em que a cúpula de Madri ocorreu - poucos meses depois do 11 de setembro e do discurso de George W. Bush em defesa do unilateralismo -, podemos supor que a declaração está estabelecendo uma posição contra o discurso do unilateralismo nas relações internacionais. Ao mesmo tempo, a declaração de Madri é explícita sobre sua dívida com a Carta das Nações Unidas. Neste documento, portanto, a intertextualidade aparece de duas formas: implícita (na relação com o discurso americano) e explícita (na referência aos princípios da ONU).

O mesmo poderia ser dito sobre a referência da Declaração de Madri ao Tribunal Penal Internacional. O compromisso de "promover a adesão universal ao Estatuto de Roma ${ }^{21 "}$ (Madri, 2002, p.2) se contrapõe indiretamente àqueles que não ratificaram o documento, sobretudo os Estados Unidos. O governo Bush não é citado, mas atua como um "outro ausente" contra o qual a declaração constroi o seu argumento.

Por meio desta prática discursiva, a União Europeia e a América LatinaCaribe tentam fixar o ponto nodal de diferença em relação aos Estados Unidos, apresentando-se como defensoras do multilateralismo nas relações internacionais. Como vimos nos capítulos anteriores, há aqui um processo de construção de iden-

\footnotetext{
${ }^{21}$ O Estatuto de Roma é o documento que estabelece o Tribunal Penal Internacional.
} 
tidade baseado na lógica da diferença entre Estados Unidos e União EuropeiaAmérica-Latina-Caribe. Tenta-se fixar o ponto nodal de que existiria uma identidade comum à Europa e à América Latina: a de defensoras do multilateralismo. Ao mesmo tempo, os Estados Unidos são vistos como promotores do unilateralismo, como se outros governos não tivessem adotado ideias diferentes.

Outro exemplo de intertextualidade aparece no tratamento dado ao terrorismo nas declarações. No documento assinado no Rio, em 1999, portanto antes do 11 de setembro, a referência ao terrorismo é breve (pouco mais de duas linhas) e limita-se a uma condenação. O texto propõe "reforçar as acções individuais e conjuntas contra o terrorismo em todas as suas formas e manifestações, dado que estas últimas minam a paz, o Estado de direito e a democracia” (Rio, 1999, p. 4).

Na segunda cúpula, realizada em Madri, em 2002, ou seja, depois do 11 de setembro, vemos um aumento do espaço dedicado ao terrorismo na declaração final. O texto não se contenta em condenar o terrorismo, mas aponta as medidas e os princípios que devem guiar esse combate.

Combater o terrorismo, em todas as suas formas e manifestações, (...), de acordo com a Carta da ONU e no pleno respeito pelo direito internacional, incluindo os direitos humanos e as normas do direito humanitário. Comprometemo-nos a reforçar os nossos mecanismos de cooperação política, judiciária e operacional e a promover a celebração de todas as convenções internacionais sobre terrorismo, assim como a adesão às mesmas, e a implementação das resoluções da ONU nessa matéria" (Madri, 2002, p. 2).

A Declaração de Guadalajara reitera que combaterá o terrorismo e todas as suas formas e manifestações “em estrita observância do Direito Internacional, e em especial ao dos direitos humanos, e do Direito Internacional Humanitário" (Guadalajara, 2004, p.3). A intertextualidade e a inspiração nos documentos da ONU é explicitada na frase "declaramos nosso pleno apoio à implementação de todos os compromissos da Resolução 1373 do Conselho de Segurança das Nações Unidas e da Resolução XLIX/60 da Assembléia Geral, bem como das Convenções pertinentes das Nações Unidas" (loc. cit.).

Em suma, depois do 11 de setembro, o terrorismo se transformou num tema onipresente nos documentos diplomáticos e adquiriu importância nas declarações de cúpula. Há uma intertextualidade entre o discurso do governo Bush e o discurso das cúpulas, ainda que essa intertextualidade ocorra por oposição. A ideia 
de que se combaterá o terrorismo com "respeito aos direitos humanos" vai de encontro à política americana de usar qualquer meio para eliminar o terrorismo. Vale notar que os Estados Unidos não são mencionados no texto das declarações, permanecendo como um "Outro" - ausente, porém fundamental - para a construção da imagem da União Europeia e da América Latina como regiões que adotam uma postura ética em relação ao terrorismo.

Mas, paralelamente a essa lógica de diferenciação entre Estados Unidos e a associação birregional, ocorre uma cisão na própria "comunidade imaginada" União Europeia-América Latina-Caribe. Apesar do uso dos pronomes "nós", "nossa", "nosso", um exame minucioso do texto revela a presença de múltiplas vozes.

Tomaremos medidas para erradicar a corrupção (...) expressamos nossa preocupação com as práticas corruptas, ilegais e fraudulentas de alguns servidores públicos e executivos de certas empresas nacionais e transnacionais que acarretam consequências econômicas negativas, especialmente para os países em desenvolvimento" (Guadalajara, 2004, p. 5).

O verbo da frase acima está conjugado na primeira pessoal do plural, dando a impressão de que existiria um "nós", enquanto o advérbio "especialmente" realiza uma cisão desse "nós". Poderíamos dizer que o advérbio provoca uma desestabilização do ponto nodal que apresenta uma imagem de comunidade. O advérbio "especialmente" destaca que há países desenvolvidos e em desenvolvimento. Além disso, sugere que os problemas referidos, como corrupção e práticas ilegais, estão "especialmente" presentes nos países em desenvolvimento. Há uma suposição de que países em desenvolvimento estejam mais sujeitos à corrupção e a práticas ilegais; eles seriam mais vulneráveis a essas mazelas.

A divisão, dentro da associação estratégica, entre países com interesses distintos pode ser verificada em outras três ocasiões:

devemos exercer um papel proeminente na construção de uma Organização Mundial de Comércio abrangente e inclusiva, (...) e que leve em consideração o tratamento especial e diferenciado, a fim de auxiliar na integração de países em desenvolvimento à economia mundial”.

Promoveremos medidas para melhorar o processo decisório e o funcionamento dos organismos financeiros internacionais, assim como para reformar a arquitetura financeira internacional, com vista a adotar medidas ori- 
entadas a prevenir e resolver satisfatoriamente as crises financeiras e a melhorar as condições financeiras dos títulos internacionais de endividamento, tendo em conta a situação dos países em desenvolvimento".

Empenhar-nos-emos para encontrar uma solução eficaz, justa e duradoura para o problema da dívida que afeta os países da América Latina e do Caribe" (Guadalajara, 2004, p.10).

Na primeira frase, a associação estratégica (o sujeito) vai auxiliar a integração de países em desenvolvimento (o objeto) na economia mundial. Na segunda sentença, as dificuldades dos países em desenvolvimento são reforçadas devido à "situação", supostamente precária, em que se encontram. A palavra "situação" funciona como um diagnóstico dos países em desenvolvimento, um diagnóstico que confirmaria a necessidade de ajuda. $\mathrm{O}$ último trecho destacado reitera que alguma ajuda é necessária e que uma solução deve ser encontrada.

Vemos nos parágrafos acima destacados que os países em desenvolvimento e os países da América Latina e do Caribe ${ }^{22}$ são tratados como carentes de ajuda por parte da associação birregional para se integrarem à economia mundial, adotarem medidas contra a crise financeira e resolverem seu problema da dívida. Portanto, a América Latina e o Caribe deixam de ser protagonistas na associação estratégica para se transformarem em objeto de intervenção da associação. De uma certa forma, o discurso dos documentos de cúpula acaba negando aquilo que pretendia afirmar: o protagonismo da União Europeia e da América Latina e do Caribe.

No exemplo acima, vimos como a América Latina e o Caribe passaram de protagonistas a objeto da associação. Na declaração de Viena, a União Europeia se transforma no único sujeito da associação. É ela que se encarrega da ajuda ao desenvolvimento dos países da América Latina e do Caribe. A frase "reconhecemos os novos e ambiciosos compromissos assumidos pela UE tendo em vista melhorar os aspectos de quantidade, qualidade e eficácia da sua ajuda ao desenvolvimento" (Viena, 2006, p.19) mostra que a União Europeia assumirá compromissos com a ajuda ao desenvolvimento. Por outro lado, a função de objeto da

\footnotetext{
${ }^{22}$ Vale notar que o documento assinado em 2004 apresenta a América Latina e o Caribe como regiões vulneráveis a crises internacionais e que deveriam ser ajudadas pela associação estratégica em caso de turbulência. Pressupõe-se que estas regiões estejam predispostas à instabilidade econômica. A crise de 2008 revelou o equívoco desta formulação pois foram os países europeus que não conseguiram financiar suas dívidas e precisaram pedir ajuda a organismos internacionais.
} 
América Latina e do Caribe é reforçada: "Reconhecemos as iniciativas (...) para ajudar alguns países da ALC" (Viena, 2006, p.20). O "nós" da associação estratégica é assim desmembrado em um sujeito (a Europa) e um objeto (a América Latina e o Caribe) que recebe a intervenção e a ajuda daquele sujeito.

A declaração de Guadalajara também se revela paradoxal quando trata da migração, tema que será discutido com mais detalhes no nosso próximo capítulo. O documento defende uma abordagem integral das migrações, com respeito aos direitos humanos e reconhecimento da contribuição dos imigrantes para o desenvolvimento econômico e para a vida social e cultural. Nesse sentido, a associação birregional se compromete a combater a violência contra imigrantes. Com este objetivo, tanto a declaração de Guadalajara quanto as subsequentes apontam a necessidade de prevenir a migração ilegal. No entanto, esta "prevenção", que é apresentada como uma medida para proteger o migrante de redes de tráfico, significa, na prática, um fechamento da fronteira.

O tema das migrações permanecerá nos dois encontros seguintes, o de Viena e o de Lima. A Declaração de Viena, por exemplo, reitera a contradição do discurso de Guadalajara: reconhece os benefícios da migração e, ao mesmo tempo, condena as migrações irregulares. Já a Declaração de Lima lembra "os laços históricos e culturais que sempre existiram entre a América Latina e o Caribe e as nações da União Europeia" (2008, p.8). Admite-se que houve um "impacto positivo dos fluxos migratórios em ambas as direções" (loc. cit). Mas, assim como os anteriores, o documento assinado em Lima vai reforçar a distinção entre "migração regular e irregular" (loc. cit.) e a necessidade de uma administração ordenada dos fluxos migratórios. A “administração ordenada” é um eufemismo para os "programas de retorno" destinados aos imigrantes irregulares. O texto também tenta apresentar esses programas de forma agradável, utilizando adjetivos como "voluntário, digno e sustentável".

O discurso dominante sobre as migrações, presente tanto na Carta da ONU quanto nas declarações de cúpula da União Europeia e da América Latina e Caribe, considera compatível tratar de direitos humanos e restringir a migração irregular. $\mathrm{O}$ argumento é o de que o combate ao tráfico ilegal de pessoas é uma forma de proteger os seus direitos humanos. Esquece-se, porém, que a própria noção de "migração ilegal" é um produto de normas estatais. Em outras palavras, o Estado estabelece os critérios para entrada em seu território e é a partir destes 
critérios que podemos falar em "migração ilegal" ou "migração legal”. Neste sentido, podemos dizer que é o Estado que cria a figura da "migração ilegal". As medidas de controle do Estado são representadas como uma consequência da migração ilegal, quando na verdade elas são a causa desse tipo de migração.

Portanto, paralelamente a uma abordagem sintonizada com a perspectiva dos direitos humanos, vemos uma tendência à restrição da migração. As declarações, que num primeiro momento pareciam monofônicas, revelam-se polifônicas, com diferentes vozes em confronto: aquelas que adotam uma abordagem humana das migrações e aquelas que defendem maior controle na fronteira.

A questão migratória, que será o tema principal de nosso próximo capítulo, revela uma divisão na associação estratégica. Se de fato houvesse um "nós", uma "comunidade imaginada" baseada em laços históricos, a migração de latinos para a Europa não seria um problema. Apesar do discurso da declaração de Lima sobre o "impacto positivo dos fluxos migratórios em ambas as direções" (2008, p.8), a Europa continua a restringir a entrada de latino-americanos.

Esta breve análise de algumas passagens das declarações mostra dois momentos da polifonia. Em alguns trechos, a associação estratégica está coesa e "responde" a um "outro ausente", os Estados Unidos. Em outros, há uma fratura na associação estratégica. Por vezes, União Europeia e América Latina estão em campos opostos, defendendo interesses diversos. É nestes momentos, como vimos no capítulo 1, que a Europa se aproxima da visão dos Estados Unidos, formando com este o "western bond".

Como destacou Bakhtin, a polifonia está sempre presente, ainda que de forma implícita. O discurso aparentemente neutro, consensual, pacífico e monológico das declarações de cúpula está, na verdade, em confronto com outras vozes que o tempo todo procuram desestabilizar o seu ponto nodal. O discurso sobre uma comunidade transatlântica (western bond), por exemplo, desafia o ponto nodal que sustenta a associação estratégica, baseado numa cadeia de significantes em que apareceriam os termos valores latinos, Europa, América Latina, história comum, direitos humanos, respeito à lei internacional, não-intervenção etc.

A seção anterior foi destinada a mostrar alguns exemplos de monofonia e polifonia nas declarações de cúpula. Neste item, vamos discutir como os conceitos de monofonia e polifonia se relacionam com as oposições hierárquicas em vários momentos do texto das declarações. Como vimos no capítulo teórico, a 
monofonia ocorre quando uma oposição hierárquica se cristaliza. Um exemplo seria a oposição entre razão e emoção, em que a primeira corresponde ao termo superior da relação e a segunda ocupa posição residual e secundária. Uma oposição hierárquica entre razão e emoção caracteriza um discurso monofônico em que a voz predominante é a da razão. Derrida diria que este é um discurso logocêntrico.

Já a polifonia se manifestaria de duas formas, como vimos, a implícita e a explícita. A polifonia implícita é marcada pelo termo secundário da oposição hierárquica (no exemplo acima, a emoção seria o elemento polifônico). Mas a polifonia só poderia se tornar explícita caso houvesse uma inversão da oposição hierárquica.

A divisão entre países desenvolvidos e em desenvolvimento não revela apenas, como vimos na seção anterior, a polifonia da associação estratégica. Há também ali uma oposição hierárquica entre desenvolvidos e em desenvolvimento, na qual a superioridade dos primeiros lhes daria o direito e o dever de ajudar os países em desenvolvimento.

É esta hierarquia entre os países que cria as condições de possibilidade para afirmações como "auxiliar na integração de países em desenvolvimento à economia mundial", "resolver satisfatoriamente as crises financeiras (...) tendo em conta a situação dos países em desenvolvimento" e "encontrar uma solução (...) para o problema da dívida que afeta os países da América Latina e do Caribe". (Guadalajara, 2004).

Em 2002, a declaração de Madri também havia sido redigida no mesmo tom, afirmando que "alguns países em desenvolvimento têm constrangimentos que dificultam a sua integração no sistema econômico e comercial internacional" (Madri, 2002, p.11). Depois deste diagnóstico de constrangimentos e dificuldades, segue-se a solução: "medidas de assistência técnica relacionadas com o comércio e outras medidas de capacitação para ajudar a uma melhor integração" (loc. cit.). Ou seja, os países em desenvolvimento se mostram incapazes de superar os constrangimentos sozinhos e, por isso, precisariam de assistência e ajuda dos mais experientes.

No livro Imperial Encounters, Roxanne Lynn Doty mostrou como a ajuda externa tem sido um tema recorrente nas relações Norte-Sul. A ajuda externa funcionaria como uma prática discursiva que constroi identidades a partir de uma 
hierarquização entre os que sabem e os que precisam aprender. Os que sabem são os sujeitos que farão a intervenção ou prestarão ajuda àqueles que necessitam. Supõe-se ainda que os países em desenvolvimento não tenham condições de administrarem seus recursos sozinhos. Desta forma, a ajuda externa também seria responsável por introduzir "mecanismos permanentes por meio dos quais o terceiro mundo seria monitorado, classificado e colocado sob vigilância contínua" (Doty, 1996, p. 128).

A partir desta constatação, Doty argumenta que a ajuda externa seria uma técnica disciplinar e, portanto, não estaria tão distante de práticas do passado. Ela seria apenas o mais recente mecanismo disciplinador, ou melhor, uma variação de um antigo ritual de poder. Ao examinar discursos sobre ajuda externa dos anos 60, Doty conclui que o objetivo dos programas de assistência era evitar que países do terceiro mundo se transformassem num perigo para a ordem internacional. O perigo não era a pobreza em si, mas "as identidades daqueles que estavam empobrecidos, pessoas que supostamente não conseguiam ter uma visão de longo prazo sobre seus problemas" (Doty, 1996, p. 131).

Vimos que as declarações de cúpula constroem o seu discurso contra uma ameaça representada pelo sistema internacional anárquico, como pode ser verificado na lista apresentada na introdução deste capítulo. Existe um mundo globalizado prenhe de perigos, ameaças, instabilidades e a associação estratégica funcionaria como uma espécie de blindagem contra essa desordem. União Europeia e América Latina e Caribe estariam unidas contra eventuais ameaças do sistema anárquico.

No entanto, em alguns momentos, a América Latina e o Caribe serão a própria ameaça. As oposições hierárquicas entre desenvolvidos e em desenvolvimento presentes nas declarações de cúpula reproduzem o discurso sobre o perigo potencial dos mais pobres. Os países em desenvolvimento precisariam ser ajudados para que a associação estratégica não fosse prejudicada: "Superar a pobreza, a desigualdade e a exclusão é crucial para alcançar a coesão social, o desenvolvimento sustentável e para a efetividade de nossa parceria birregional" (Lima, 2008, p.3).

Aqui, pode-se perceber que o discurso da associação estratégica afirma exatamente aquilo que pretendia negar: a desigualdade nas posições da União Europeia e da América Latina e Caribe. O texto sustenta que a América Latina e o 
Caribe são áreas "em desenvolvimento" que necessitam de ajuda, mas, ao fazê-lo, nega a existência de uma associação estratégica entre iguais.

\section{3}

\section{Uma genealogia das oposições hierárquicas}

Até o momento, analisamos os textos no eixo sincrônico, procurando detectar como ocorria a polifonia e a intertextualidade entre as declarações de cúpula e outros discursos contemporâneos, como o dos Estados Unidos e o das Nações Unidas. Nesta seção, vamos empreender uma análise genealógica das declarações, o que implicará um deslocamento para o eixo diacrônico. A genealogia está mais interessada no presente do que no passado pois ela só se reporta a outras épocas com o intuito de problematizar e desnaturalizar o presente. Portanto, nosso objetivo não é um aprofundamento em períodos históricos passados, mas apenas um retorno ao passado que permita iluminar o "lado obscuro do presente".

Em consonância com nosso marco teórico já explicitado, esta análise não se interessa em descobrir se havia ou não má fé por parte dos autores das oposições hierárquicas. Nosso objetivo não é investigar as intenções dos chefes de Estado e de governo da União Europeia e da América Latina e do Caribe. Pretendemos apenas mapear a intertextualidade entre as declarações e uma série de práticas representacionais. Em outras palavras, o texto das declarações deve ser analisado como produto de práticas representacionais entre União Europeia e América Latina. Consequentemente, o significado dos textos não se limita às intenções dos autores.

A oposição hierárquica entre desenvolvido e em desenvolvimento presente nas declarações parece uma "variação na repetição" de práticas representacionais que permeiam a relação entre União Europeia e América Latina e Caribe. Como vimos, a diferenciação entre "desenvolvido" e "em desenvolvimento" cria as condições de possibilidade para que os mais desenvolvidos prestem assistência aos demais.

Esta assistência, porém, como mostrou Doty ao analisar a ajuda externa nos anos 60, não significa apenas recursos econômicos. Supõe-se que os ainda não desenvolvidos não tenham condições de aplicarem sozinhos a ajuda recebida. Eles 
seriam carentes de uma visão de longo prazo. Os discursos sobre a ajuda externa, portanto, também criam uma "identidade" para aquele que recebe o auxílio. Ao mesmo tempo, é esta identidade "carente de uma visão de longo prazo" que justifica o auxílio.

\subsection{1}

\section{O cristão e o não-cristão}

Nos séculos XVI e XVII, as identidades da Europa e da América foram constituídas mutuamente por práticas discursivas que se baseavam na oposição hierárquica entre cristão e não-cristão ou europeu e indígena. Outra oposição do período é aquela entre europeu e selvagem/bárbaro/antropófago.

Ao relatar uma catástrofe ocorrida na Flórida durante o século XVI, o conquistador espanhol Alvar Nuñez Cabeza de Vaca admitiu que era prazeroso ver "aqueles selvagens, que não foram ensinados, uivarem como brutos por compaixão por nós" (COVEY, 1983, p.1). Contudo, a palavra mais usada por Cabeza de Vaca em seu relatório de viagem aos reis espanhóis era cristão, como se pode ver nos seguintes trechos: “À noite, um dos cristãos que haviam saído para buscar água foi atingido por uma flecha (...) Todos os indígenas haviam fugido durante a noite". "Acabei ferido, junto com dois ou três outros cristãos". "Era noite quando os indígenas retornaram, sem água nos containeres e sem os cristãos". "De manhã, vieram índios em várias canoas, pedindo que soltássemos nossos reféns. O governandor respondeu que o faria quando os índios trouxessem os dois cristãos" (loc.cit).

A identidade cristã é tão ubíqua no discurso do século XVI que muitas vezes ela acaba por substituir a palavra homem. Em todas as frases acima destacadas, o termo "cristãos" poderia ser substituído, sem qualquer perda semântica, pela palavra "homens".

A palavra cristão será inserida em uma cadeia de significantes em que aparece em associação com civilização, ordem humana e cura. Em seu estudo sobre o colonizador espanhol, Covey destaca que ele queria levar a civilização e a cristandade aos indígenas e estabelecer uma ordem humana entre eles. "Ele havia descoberto que podia curar a doença deles, comunicando-lhes os ensinamentos cristãos" (loc.cit). 
Civilização e cristandade aparecem como termos correlatos, sinônimos. Ser civilizado significava ser cristão. Mais: o civilizado e o cristão se opõem ao indígena numa oposição hierárquica em que o cristão é o termo superior e provido de civilização. Já o indígena é uma página em branco que pode receber a civilização ofertada pelo cristão. Daí a afirmação "levar a civilização e a cristandade aos indígenas".

Outro objetivo de Cabeza de Vaca era estabelecer uma ordem humana entre os indígenas. A ordem humana está relacionada à cristandade; por dedução, o que não é cristão não está dentro desta ordem. Ou seja, a oposição cristão/indígena também origina a oposição entre humano e não-humano. O nãocristão é, portanto, associado ao não-humano.

No discurso do colonizador, a cadeia de significantes se completa com o termo doença. Ser indígena, não-cristão e não-humano também significaria ser doente. E a cura para esta doença estaria nos ensinamentos cristãos. Um dos pressupostos desse discurso é o de que o indígena é capaz de aprender. Esta afirmação pode parecer trivial, mas foi o resultado de acirradas disputas nos séculos XVI e XVII.

A representação do indígena "como capaz de aprender" era defendida por Bartolomé de las Casas. O indígena era pacífico e aberto aos ensinamentos cristãos. Aqui, a identidade indígena era considerada como passível de mudança, pronta para adotar os valores cristãos e europeus. Contudo, essa representação do indígena não era unânime. Para Ginés de Sepúlveda, o indígena vivia como um selvagem, praticando o canibalismo. "Aqui está a prova de sua vida selvagem (...) o fato de devorarem carne humana" (Sepúlveda apud Hanke, 144-49). Para o dominicano Tomás de Ortiz, os indígenas "comem carne humana", "são incapazes de aprender" e "se recusam a melhorar em qualquer coisa" (Ortiz apud Campbell, 1998, p. 101). Diante desta constatação de uma identidade imutável, ligada a práticas não-cristãs como o canibalismo e incapaz de aprender, só restaria aos cristãos a alternativa de escravizar os indígenas.

Em suma, o significante indígena era disputado por dois grupos, cujos discursos tentavam fixar uma identidade para o indígena. O grupo de Las Casas associava o termo indígena a significantes como pacífico, gentil, paciente, passível de ser civilizado enquanto o grupo de Sepúlveda inseria a palavra indígena numa cadeia de significantes da qual faziam parte os termos canibal, selvagem, besta, 
não-civilizado. Ambos os grupos tentavam, portanto, atribuir um fundamento, uma essência ao indígena. No entanto, a própria disputa em torno do significante vazio revela a existência de um "fundamento contingente" e de uma crise no sistema de significação. No caso do século XVI, a crise era provocada pelo assombro que a descoberta de novos povos representava para a Europa.

A fixação do significado tinha consequências práticas, uma vez que a opção pela colonização (o indígena é capaz de aprender) ou pela escravização (o indígena é um animal impossível de ser domesticado) dependia da forma como o indígena era representado.

O discurso de Cabeza de Vaca pode ser desmembrado em oposições hierárquicas como:

$\begin{array}{ll}\text { Civilização } & \text { Indígena } \\ \text { Cristandade } & \text { Não-cristão } \\ \text { Ordem Humana } & \text { Não-humano } \\ \text { Cura } & \text { Doença }\end{array}$

Os textos desse período correspondem a um discurso monológico em que a voz que aparece em primeiro plano é sempre a do europeu. É este que nomeia o indígena e o classifica como não-cristão, não-humano, canibal. Ainda que a polifonia exista, ela está implícita. Nas oposições hierárquicas, o primeiro termo é privilegiado e indica o caráter monológico do discurso. Já o segundo termo é o responsável pela polifonia implícita.

Por vezes, entretanto, é possível perceber uma explicitação da polifonia em discursos desse período. Mary Louise Pratt lembra a obra de Felipe Guamán Poma de Ayala, escrita em de 1615 numa mistura de quéchua e espanhol. O manuscrito de Poma de Ayala reescrevia a história da conquista espanhola e do cristianismo para incluir os povos americanos nativos. Ou seja, Ayala antecipa a teorização que será feita no século XX por autores pós-colonialistas que mostraram a possibilidade de questionar a histórica eurocêntrica linear a partir de um outro lócus de enunciação. A obra de Poma de Ayala é construída por hibridismos e 
enxertos, pois as vozes espanholas se misturam com as vozes nativas, formando uma justaposição que por vezes resulta num espanhol gramaticalmente incorreto. Para Bakhtin, o hibridismo resulta da mistura de "duas linguagens sociais dentro dos limites de um único enunciado" (Bakhtin, 1981, p. 358) ou "duas consciências linguísticas diferentes, separadas uma da outra por uma época, por diferenciação social" (loc. cit.). No caso do manuscrito de Poma de Ayala, temos duas consciências linguísticas separadas por diferenciação social: a do colonizador espanhol e a do nativo.

O monologismo do discurso europeu do período se manifesta ainda na tentativa de fixar uma identidade e uma essência para o cristão e o indígena. O primeiro seria bondoso, civilizado e humano, enquanto o segundo estaria desprovido daquelas qualidades. Supõe-se que estes atributos constituam, na verdade, uma essência, um fundamento da identidade.

Apesar desta formulação inicial de um fundamento da identidade, o discurso sobre a ajuda e o auxílio pressupõe necessariamente a possibilidade de transformação da identidade. Aquele que será ajudado tem capacidade para aprender, modificar-se, equiparar-se ao provedor do auxílio. Portanto, há aqui implícita uma concepção de identidade pós-fundacionalista. Desta forma, o discurso sobre a ajuda desconstroi a própria base (a oposição hierárquica entre identidades fixas) que o sustentava no início.

Vimos nas declarações de cúpula que a hierarquia entre países desenvolvidos e em desenvolvimento permitia que os primeiros se posicionassem como os doadores de ajuda aos demais. Nota-se nas declarações uma "repetição com variação" da ideia de ajuda externa dos anos 60 e das práticas discursivas dos séculos XVI e XVII.

Nos anos 60, a pobreza dos países em desenvolvimento era a "doença" que devia ser combatida por meio da ajuda externa. Da mesma forma, o paganismo e o canibalismo dos indígenas era a doença que deveria ser curada pelos ensinamentos religiosos. A oposição hierárquica entre cristãos e indígenas criava as condições de possibilidade para que o cristão ajudasse o indígena a se tornar um cristão.

Os discursos se aproximam ainda em relação à questão da ameaça e do medo. A pobreza dos países em desenvolvimento nos anos 60 significava uma ameaça à ordem liberal; eles representavam um perigo que poderia ser debelado 
caso os desenvolvidos contribuíssem para o desenvolvimento dessas regiões. Por outro lado, os indígenas representavam uma ameaça à ordem humana por não serem cristãos; se fosse possível transformá-los em cristãos _ o que os europeus se empenharam em fazer - , o problema estaria resolvido.

Pela análise do discurso das cúpulas, vimos que um dos objetivos da associação estratégica era justamente proteger os países participantes das ameaças do mundo anárquico. Porém, em alguns momentos, o discurso das declarações aponta os próprios países em desenvolvimento participantes da associação estratégica como uma possível ameaça ao projeto de criação de um espaço birregional. Eles representariam uma ameaça por conta da pobreza e da instabilidade econômica. Para combater este perigo, os países desenvolvidos se comprometeriam a ajudar aqueles considerados "em desenvolvimento".

Apesar da distância temporal, há regularidades entre os discursos dos séculos XVI e XVII e os das cúpulas União Europeia-América Latina-Caribe. Ambos são marcados por um jogo de regras representado por oposições hierárquicas e monologismos. A oposição desenvolvido/em desenvolvimento seria uma dispersão da hierarquização entre cristão e indígena. A dispersão, como se pode constatar, depende de condições histórico-empíricas, portanto, do espírito da época. Os encontros dos séculos XVI e XVII eram perpassados por uma visão religiosa do mundo; por isso, a tentativa de classificar a humanidade em cristãos e nãocristãos. No contexto do século XXI, marcado pela globalização, percebe-se a onipresença da distinção entre países desenvolvidos e em desenvolvimento.

Não estamos sugerindo a existência de uma formação discursiva que significaria uma continuidade ou uma totalidade histórica entre os dois tipos de discurso acima analisados. De acordo com o conceito de formação discursiva que adotamos (a interpretação de Laclau e Mouffe sobre Foucault), a formação discursiva não se assemelha a uma estrutura rígida, que seria repetida sem variação de um século para outro. Ao contrário, a formação discursiva é composta por práticas de articulação mais ou menos precárias, o que possibilita a abertura e a dispersão. As dispersões ou rupturas apresentarão novos termos para a oposição hierárquica predominante nos séculos XVI e XVII.

Uma analogia entre os pares cristão/não cristão e desenvolvido/em desenvolvimento estaria vulnerável à acusação de anacronismo. O argumento seria o de que projetamos a lógica da ajuda externa para o contexto da expansão do cristi- 
anismo nas Américas nos séculos XVI e XVII, perdendo com isto a especificidade do momento histórico do "descobrimento".

No entanto, não estamos adotando o programa metodológico de Quentin Skinner, segundo o qual devemos resgatar a intenção do autor no texto que lemos, evitando assim o anacronismo. Segundo Skinner, o perigo do anacronismo seria afastado se não contaminássemos o resgate das intenções com nossas expectativas. Contudo, como expusemos em nosso capítulo teórico com Lacapra, esse modelo positivista de total neutralidade do observador não se sustenta. Qualquer análise do discurso de outras épocas será influenciada, em maior ou menor proporção, por um quadro de inteligibilidade contemporâneo. A própria ideia de anacronismo pressupõe uma representação da História como uma linha reta direcionada para o futuro. Consequentemente, cada período ocupa um determinado lugar na linha histórica e não se mistura com os demais. $\mathrm{O}$ anacronismo significa uma desorganização cronológica, uma mistura de tempos, um hibridismo de temporalidades.

Além disso, a própria ideia de que se deve recuperar a intenção do autor é incompatível com nossa orientação teórica de considerar, seguindo Bakhtin, Derrida e Foucault, que não há completa autonomia do sujeito no uso da linguagem. Portanto, não nos interessa investigar a intenção do cristão nos séculos XVI e XVII e tentar compará-la com a intenção dos que oferecem ajuda externa no século XXI. O objetivo é mostrar que existem práticas representacionais (oposições hierárquicas) na relação entre Europa e América Latina-Caribe que vem se renovando nas declarações de cúpula independentemente da intenção dos autores.

\subsection{2}

\section{Bárbaro, Selvagem, Canibal}

A oposição hierárquica entre europeu e bárbaro/canibal/antropófago/selvagem está presente em vários períodos históricos, mas deve ser compreendida a partir da dispersão do significado. Não temos uma oposição europeu/bárbaro que tenha perdurado por séculos. Antes, observamos uma série de oposições hierárquicas nas quais os termos são deslocados e substituídos por outros. 
O termo bárbaro já era utilizado na Grécia antiga para designar todo aquele não fosse grego e não possuísse logos. Portanto, a oposição hierárquica prevalecente naquele período se baseava na dicotomia grego/bárbaro, sendo que o grego era o depositário de altas qualidades, enquanto o bárbaro careceria das mesmas. O bárbaro era o absolutamente outro do mundo grego e, com ele, não havia relação possível, como veremos no próximo capítulo. O bárbaro não tinha condições de aprender a língua grega e repetia vocábulos incompreensíveis, como bar-bar-bar (equivalente ao português blá blá blá). Ele não possuía logos, uma vez que não conseguia pronunciar um discurso com sentido. Portanto, a oposição grego/bárbaro traz implícita uma outra: entre aquele que tem logos (o grego) e aquele que não o possui (o bárbaro).

Desta forma, o grego utilizava-se do bárbaro para construir sua própria identidade. De acordo com Catherine Peschanski, no início havia uma indistinção entre os povos e o tempo era idêntico para todos. Isto pode ser verificado em Homero, que não utilizava a palavra bárbaro. A diferenciação ocorrerá posteriormente (já aparece em Heródoto, como vimos brevemente no capítulo 1) e instituirá uma diferença temporal entre gregos e bárbaros. Os primeiros avançam no tempo, enquanto os últimos permanecem estacionados. Cria-se, portanto, um hiato temporal no momento da diferenciação.

A partir do século XVI, o bárbaro aparecerá no discurso europeu na mesma cadeia de significantes de canibal, antropófago, selvagem ou mesmo nãocristão. Ou seja, o significante bárbaro, que no século V a.c. significava nãogrego, será associado a uma série de outros vocábulos num novo contexto. Segundo Pagden “os antropófagos (...) têm desempenhado o seu papel na descrição das culturas não europeias, desde que o primeiro grego se aventurou pelo lado ocidental do Mediterrâneo" (Pagden, 1986, p.80-81).

O termo canibal irrompe no século XV em substituição à palavra antropófago. Como vimos no capítulo 2, “canibal" é um dos primeiros neologismos produzidos pela descoberta do Novo Mundo. Segundo Carmen Nocentelli-Truet, a palavra "canibal" aparece pela primeira vez no discurso europeu numa anotação de 23 de novembro de 1492 do diário de Cristóvão Colombo. O genovês teria se aproximado de uma ilha habitada por um povo conhecido como "canibales", que teriam um só olho e seriam muito belicosos. A partir desse relato, Peter Martyr descreveu os caribes como antropófagos. O termo voltará a surgir nos textos de 
Francisco López de Gómara (1511-1566) e, mais tarde, nos relatos de viagem de Hans Staden (1557), André Thevet (1557) e Jean de Léry (1578).

O "mal-entendido de Colombo", na expressão do filósofo argentino Enrique Dussel, terá consequências duradouras para a relação entre Europa e América Latina. Como mostrou Todorov (ver capítulo 2), quando um autor comete um engano, seu texto não é menos significativo do que quando diz a verdade. Por esta razão, o "canibal" será um operador textual importante nos discursos da Europa sobre a América Latina, principalmente na literatura de viagem, o "conjunto das primeiras etnografias da América a serem publicadas na Europa" (Campbell, 1999, p. 27).

Segundo Raúl Antelo, a antropofagia podia ser encontrada em diversos povos, mas seu sentido acabou sendo atrelado a um grupo específico, o tupiguarani. Isto se explicaria devido à "relação agônica que o racionalismo europeu passou a estabelecer com a própria diferença latino-americana” (ANTELO, 2011, p. 219). O canibalismo configurará um desafio à razão humana. Antelo lembra uma série de obras que, nos séculos seguintes, representarão o canibal como um outro perigoso no imaginário europeu:

\begin{abstract}
O geógrafo Jean Bodin e sua cartografia da crueldade, ligando os canibais a Drácula, Duque da Transilvânia; o império da necessidade que decorre da obra de Girolamo Cardano, De rerum varietate; a paranoia canibofóbica de Robinson Crusoé, autêntica origem do romance ocidental; a dócil submissão apregoada por Voltaire; o canibalismo reivindicado como sistema econômico e política em Sade (2011, p. 219).
\end{abstract}

Portanto, a origem do romance ocidental estaria já marcada pela dicotomia europeu/indígena/canibal. Na obra de Daniel Defoe, Robinson Crusoé (1719), os canibais são representados como brutos, não humanos, perigosos. Ao contrário, o indígena que se torna seu amigo (nomeado de Sexta-feira) é capaz de aprender a sua língua. Ou seja, é possível civilizar o indígena, mas não o canibal. Defoe concilia no século XVIII os polos do debate do século XVI entre Bartolomeu de las Casas e Sepúlveda. Enquanto Las Casas insistia que os indígenas poderiam aprender, Sepúlveda considerava-os brutos irrecuperáveis. Para Defoe, os dois casos seriam possíveis: o canibal de Sepúlveda e o indígena que aprende a língua do colonizador. Novamente, a capacidade de aprender a linguagem parece ser o crité- 
rio de diferenciação entre os indígenas e os canibais. Há, portanto, uma prática representacional no discurso europeu que se reproduz no século XVIII, conservando elementos do discurso do século XVI. Um traço de semelhança entre o bárbaro e o canibal é justamente a questão da incapacidade de falar de forma articulada. O bárbaro só consegue pronunciar bar-bar-bar e o canibal de Defoe nem sequer pode ser "recuperado" pela linguagem.

Um relato do século XVI sobre um povo da América dizia que: "Vivem nus e de forma irracional, e emitem grunhidos como única linguagem. Seu aspecto é feio e desagradável. Dizem que, entre os bienbienes, há alguns que comem carne humana obtida por sacrifício" (Jáuregui, 2008, p. 283, grifo nosso). O americano é caracterizado, portanto, como aquele que come carne humana e emite grunhidos, o que demonstraria sua irracionalidade.

A incapacidade linguística também aparecerá no texto História de uma viagem, de Jean de Léry. Este descreve os canibais como destituídos de leis e ordem. Seriam também dados a atos de violência e teriam uma língua não compreendida por seus vizinhos. O problema da língua parece uma constante em todas as definições de canibal.

Ora, esta caracterização do americano como canibal o aproxima do bárbaro, segundo a definição clássica dada pelos gregos. Assim como o bárbaro, o canibal americano não possui logos (é irracional) e sua linguagem é um grunhido (o blá-blá-blá do bárbaro).

Contudo, não podemos falar apenas de continuidade. De acordo com o modelo de temporalidade que adotamos (ver capítulo 3), temos "repetição com mudança". A formação discursiva é constantemente marcada pela irrupção do acontecimento. Ao longo dos séculos, lidamos com diferentes torções da "mesma" ansiedade. Como mostra Maria Helena Rouanet, "as funções emprestadas à figura emblemática do canibal passaram por diversas variações ao longo dos cinco séculos que se seguiram ao descobrimento da América” (2011, p. 172). Estaríamos então diante de variações de uma "ansiedade canibal" que tem marcado as relações entre a Europa e a América Latina e o Caribe.

Outro discurso da mesma época indagava: "que humanidade, que clemência, que moderação mereciam aqueles naturais, quando eles, desprovidos de toda humanidade, incessantemente estavam devorando uns aos outros? Mais 
irracionais do que as próprias feras, faziam o que nenhum bruto faz: alimentar-se dos indivíduos de sua própria espécie” (Ibidem, p. 236, grifo nosso).

O canibal é o símbolo do limite entre o humano e o não-humano. Devese lembrar que a desumanidade, aqui atribuída ao americano, também já havia aparecido na caracterização do não-cristão no discurso de Cabeza de Vaca.

$\begin{array}{ll}\text { Bárbaro } & \text { Americano } \\ \text { Não tem logos } & \text { Irracional } \\ \text { Balbucia } & \text { Emite grunhidos } \\ \text { Não-grego } & \text { Não-cristão } \\ & \text { Não Humano } \\ & \text { Antropófago } \\ & \text { Canibal }\end{array}$

Sem lei e ordem

O bárbaro e o americano são aproximados um do outro pelo discurso europeu do século XVI. O significante "europeu" irá substituir o termo "grego" na oposição hierárquica grego/bárbaro. Paralelamente, o americano é incluído numa cadeia de significantes em que ele aparece como detentor das mesmas características dos bárbaros. Temos, assim, a transformação gradativa da oposição grego/bárbaro na dicotomia europeu/americano.

No entanto, o termo canibal será usado dentro da própria Europa contra um "outro interno". Na análise de Nocentelli-Truet, o canibalismo entrou no debate entre católicos e protestantes na França do século XVI. Os reformadores protestantes acusavam os católicos de diversas formas de canibalismo. Eventualmente, os católicos não hesitariam em devorar protestantes. Simbolicamente, a hóstia era um ritual antropofágico. As fogueiras para os hereges eram comparadas à preparação da comida pelos canibais. Já a cobrança de dízimos e indulgências pela Igreja Católica era classificada como "canibalismo econômico". Em suma, a tentativa de defender uma identidade religiosa fez com que o termo canibal fosse dirigido a europeus cristãos e não apenas a americanos não-cristãos. $O$ ensaio de Montaigne, avalia Nocentelli-Truet, teve o mérito de afastar o termo canibal do 
espaço europeu, restringindo-o ao Novo Mundo. Isto possibilitou que a França se unisse em torno do Estado-nação e deixasse a diferença religiosa de lado.

A pesquisa de Nocentelli-Truet mostra que o significante "canibal" é atribuído ao "outro" sempre que se busca construir ou fortalecer a própria identidade. Retomando a leitura de Laclau e Mouffe, a formação discursiva possui um "significante flutuante ou vazio" e é este elemento que permitirá a variação e dispersão do significado. O significante flutuante "canibal", por exemplo, é preenchido por diversos significados conforme os grupos que tentam fixá-los.

Este processo se daria de acordo com a lógica da diferença, a qual tenta fixar as posições e identidades dos agentes sociais. Quem designa o outro como canibal pretende que este tenha uma essência bárbara, violenta, irracional. Por oposição, a essência daquele que nomeia seria benévola e racional.

Contudo, a lógica da diferença é minada pela lógica da equivalência, que revela o caráter contingente das identidades. A oposição entre católicos e protestantes é transformada em união sob os auspícios do Estado. As identidades religiosas "católico" e "protestante" perdem espaço para a identidade nacional francesa. Nesse processo, o canibal deixa de ser um elemento da disputa entre católicos e protestantes para funcionar como o "outro externo" contra o qual a identidade francesa se constitui. O deslocamento do termo "canibal" de um grupo para outro evidencia que não existem povos intrinsecamente canibais. $\mathrm{O}$ que temos são práticas discursivas que associam determinados povos a canibais com o intuito de estabelecer uma diferenciação. Assim, o discurso europeu do século XVI acaba por negar justamente aquilo que pretendia afirmar, qual seja, uma associação do canibal com o não-cristão e o não-europeu.

\subsection{3}

\section{Civilização e Barbárie}

A oposição hierárquica entre europeu e bárbaro/canibal/antropófago conhecerá algumas modificações a partir da introdução na cadeia de significantes do termo civilização. O vocábulo civilização "surgiu no início do século XVII a partir do francês civiliser, do século XVI" (Williams, 2007, p. 82). Mas nesta época a 
palavra ainda não tinha o sentido que hoje atribuímos a ela. Significava então "transformar uma questão criminal em uma questão civil e, por extensão, incorporar a uma forma de organização social" (loc. cit). Civilização no sentido de estado ou processo que se refere a toda a sociedade aparecerá no século XVIII. De acordo com Starobinski, quem primeiro utilizou essa acepção foi o marquês de Mirabeau (1749-1791). Esse novo significado tornar-se-á mais comum no final do século XVIII e no XIX.

O termo civilização também aparecerá associado numa cadeia de significantes com a ideia de progresso e é a partir desse momento que ela será contraposta a barbárie, o estado daqueles que não conhecem o progresso. Tal como a distinção entre grego e bárbaro, a oposição entre civilizado e bárbaro vai relegar este último a um espaço a-histórico e marcado pelo imobilismo. Como bem destaca Newton Bignotto, "o civilizado recriou a figura do bárbaro" (2004, p. 72). A "civilização" adquire ainda um caráter normativo pois indica o caminho que todos os povos devem seguir se não quiserem desaparecer. Implícita nesta abordagem normativa está a ideia, já vista no item anterior, de que o aprendizado é possível. O bárbaro pode imitar o civilizado e dele se aproximar na trilha do progresso. Pressupõe-se, portanto, que a identidade do bárbaro possa ser transformada e convertida numa identidade de civilizado.

Na nova prática articulatória do século XVIII, o significado de "bárbaro" sofre uma ligeira modificação. Na concepção tradicional, o bárbaro é definido como aquele que não consegue aprender a linguagem; é um selvagem que só consegue balbuciar. No entanto, numa cadeia de significantes em que já aparecem os termos civilização e progresso, o significado de bárbaro se transforma. Bárbaro é aquele que pode civilizar-se. O lugar do "incapaz de aprender" passa a ser ocupado nesta cadeia de significantes por um outro termo: o "selvagem". Temos, assim, uma hierarquização entre selvagem, bárbaro e civilizado.

Este movimento dos significantes de um período para outro revela a historicidade das articulações, ou seja, o fato de que elas não são naturais nem se baseiam em um fundamento. Ao contrário, as práticas articulatórias são marcadas pelo deslizamento do significado ao longo do tempo. O bárbaro, assim como o canibal, é o termo que não conhecerá "sossego semântico", como afirmou Jáuregui, deslizando no espaço da différance colonial. 
Diante da proliferação de significados para a barbárie, Francis Wolff enumera três sentidos e os conceitos de civilização que correspondem a cada um deles. Uma das acepções seria utilizada para designar aquele que come carne humana, ou seja, o canibal. O segundo significado de barbárie estaria ligado à depredação de um objeto sagrado (um monumento, um templo). E, por fim, usaríamos barbárie para nos referir ao extermínio de pessoas (aqui o termo barbárie viria associado na cadeia de significantes a genocídio).

No primeiro caso, bárbaro seria sinônimo de canibal, como vimos acima. Em contraste, a civilização seria definida como refinamento de costumes. Supõese que as sociedades passem da barbárie à civilização e deixem para trás o primitivo hábito do canibalismo. O progresso em direção à civilização dependeria da superação desse costume bárbaro. Aqui, a civilização assemelha-se a um processo de modelagem da sensibilidade e do comportamento humano (Elias, 1994).

A segunda acepção de bárbaro, como aquele que destroi objetos sagrados, se oporia à noção de civilização entendida como ciência, letras e artes. O bárbaro furta obras de arte para poder vendê-las por um bom preço e queima bibliotecas. O bárbaro, nesta concepção, só se preocupa com o lado prático da vida e, por isso, despreza o saber e a beleza pura. Para ele, o saber deve ser direcionado a um fim e a uma utilidade. É este sentido de civilização e barbárie que será empregado por europeus ao se referirem aos americanos em determinados períodos históricos. Como vimos no capítulo 1, o europeu do século XIX não considerava o americano um "bárbaro-canibal", mas um "bárbaro que só se preocupa com dinheiro e questões utilitárias". Este tipo de prática discursiva já estava presente em Alexis de Tocqueville, que, em sua obra "Democracia na América", descreveu os americanos como pouco afeitos às artes, à literatura e à música.

A barbárie poderia equivaler ainda à perda de qualquer sentimento humanitário. Atos cometidos por regimes ditatoriais contra seu próprio povo, extermínio em massa, limpeza étnica. Em contraste, a civilização designaria aqueles que respeitam os direitos humanos dos povos. Estas definições de barbárie e civilização estão presentes nos discursos contemporâneos sobre intervenção humanitária. Acredita-se que os Estados civilizados possam intervir para estancar o banho de sangue nos Estados considerados bárbaros ou, para usar uma terminologia cada vez mais recorrente no campo das relações internacionais, nos "Estados falidos". Também foi neste sentido que os termos civilização e barbárie passaram a ser uti- 
lizados no contexto da guerra da Bósnia. A "civilização europeia" se prontificou a resgatar a Bósnia do estado de barbárie em que ainda se encontrava no final do século XX (ver capítulo 2).

É interessante notar que os significantes civilização e barbárie serão preenchidos com significados ligeiramente diferentes nos vários exemplos acima. A mudança de significado de um termo acarreta invariavelmente uma mudança no outro, confirmando a ideia saussuriana de que o significado é produto da correlação entre os significantes. No entanto, também devemos lembrar aqui as interpretações de Bakhtin e Derrida sobre a estrutura da linguagem. Para estes autores, o significado resulta de uma diferenciação entre os termos do discurso, mas este processo de produção do sentido deve ser pensado dentro de um contexto. Contra o formalismo a-histórico de Saussure, Bakhtin e Derrida defendem uma linguagem historicamente situada.

Nos três sentidos de civilização e barbárie vistos acima, percebemos que há uma mudança de contexto. O significado de bárbaro como sinônimo de canibal estava inserido num contexto de "descobrimento" do Novo Mundo e constituição da identidade europeia. Mas o significado de bárbaro sofre um deslocamento quando empregado no século XIX para classificar as nações menos preocupadas com o refinamento cultural. Já no contexto pós-Guerra Fria, o bárbaro é o que provoca conflitos étnicos.

Por outro lado, também existem semelhanças entre esses três sentidos. Como explica Bakhtin (...), o significante carrega consigo a memória de significados passados. Em Derrida, a différance prevê que cada elemento presente relaciona-se com algo que está ausente, guardando em si o rastro do passado.

Portanto, o deslocamento na cadeia de significantes não implica total ruptura, mas uma continuidade ou repetição com variação. Quando o europeu se refere a um norte-americano como bárbaro, ele quer dizer que o "outro americano" não é culturalmente refinado. Só que este significado não deixa de evocar aquele canibal que não cultivava as artes, a música e a literatura. Portanto, o significante bárbaro utilizado no contexto do século XIX não está totalmente isento de sua carga semântica anterior.

Aquele que conduz um extermínio no século XX é também um "canibal", ainda que no sentido metafórico, pois "devora o outro" pertencente a uma etnia diferente. Esta devoração só ocorreria por um desconhecimento do sentimen- 
to humanitário e, consequentemente, da noção de direitos humanos. Um dos meios para fazer o canibal compreender os valores humanitários seria educá-lo nas artes. Ora, esta concepção, que conheceu grande divulgação no Ocidente no século XX, pressupunha que a arte torna o homem mais humano, o que acabou sendo desmentido pela revelação dos casos de oficiais nazistas que ouviam Wagner.

Apesar das ligeiras mudanças de significado dos termos, a oposição hierárquica entre civilizado e bárbaro não é subvertida. Em todos os exemplos vistos, o civilizado é sempre superior ao bárbaro, seja este canibal, pouco apreciador das artes ou cruelmente violento. Em outras palavras, o bárbaro é sempre o outro, como mostrou Montaigne. "Cada um chama de barbárie o que não é do seu próprio uso" (Montaigne, I, 30).

A dicotomia civilização/barbárie vem sendo utilizada também em contextos não europeus. Embora ela tenha derivado da oposição europeu/bárbaro, ela não ficará restrita ao território europeu. A América Latina e o Caribe se apropriam da oposição hierárquica civilização/barbárie, na qual eles apareciam como os bárbaros, para voltá-la contra seus outros internos. Poderíamos dizer que se passa aqui o que Walter Mignolo chamou de "colonialidade do saber". Absorvemos dicotomias surgidas num contexto europeu e as aplicamos acriticamente na América Latina e no Caribe com o intuito de criar uma divisão continental entre os que seriam civilizados e os bárbaros.

No contexto latino-americano, os civilizados seriam os descendentes de europeus, os que carregam a "latinidade", enquanto os bárbaros seriam os autóctones, o gaucho da Argentina ou o sertanejo e o caipira no Brasil. A oposição hierárquica civilização/barbárie será utilizada, portanto, para justificar a manutenção de uma sociedade estratificada.

A oposição civilização e barbárie aparece, por exemplo, nas obras de Domingo Faustino Sarmiento e Esteban Echeverría. Em Facundo: Civilização ou barbárie, Sarmiento recomendava "no ahorrar sangre de gauchos" (não poupar sangue de mestiços) como forma de combater a barbárie dos indígenas e construir uma civilização na Argentina. Havia um componente racista na visão de Sarmiento sobre a construção da nação argentina. Esta deveria ser uma civilização europeia, com o menor contingente possível de elementos autóctone e mestiço. Este ponto nos remete a uma das considerações de Quijano, qual seja, a de que o sistema de dominação social inaugurado pela modernidade no século XVI baseou-se 
na categoria de raça. De fato, o racismo esteve presente em todas as oposições hierárquicas que vimos até o momento: grego/bárbaro, europeu/bárbaro, europeu/canibal, europeu/antropófago e civilizado/bárbaro.

Em Sarmiento, a exclusão do bárbaro pode ocorrer por meio de duas estratégias complementares, o extermínio e a educação, que corresponderiam, como vimos, às estratégias de Sepúlveda e de Bartolomeu de las Casas, respectivamente. No primeiro caso, estaríamos diante de um racismo explícito. O bárbaro deveria ser exterminado por ser uma raça intrinsecamente inferior, sem possibilidade de salvação. Consequentemente, a eliminação se apresentava aos colonizadores como a única solução. A segunda estratégia se basearia num racismo implícito; entendese que a suposta inferioridade do outro possa - e deva - ser neutralizada por uma “missão civilizacional”. Para Sarmiento, a missão civilizacional se traduzia numa missão educacional destinada a criar o que ele considerava a verdadeira identidade $\operatorname{argentina}^{23}$. Sua política era "matar os índios e gauchos e ensinar os brancos a ler" (Retamar, 1977, p. 42).

A dicotomia civilização-barbárie não é uma exclusividade da obra de Sarmiento, mas um tema recorrente na literatura latino-americana. O bárbaro está sempre associado ao popular, ao indígena e ao campo, enquanto o civilizado é o moderno, europeu e urbano. Nesta tradição latino-americana, a barbárie deve ser domada pela civilização em diversas circunstâncias: na escola, na igreja e na guerra. Mais recentemente, em El gaucho insufrible, Roberto Bolaño desconstruiu a dicotomia civilização-barbárie com certa ironia. Ao retomar o tropos do campo, da natureza intocável, ele se desencanta, mostrando que não há mais esse local para o qual retornar. O campo já foi invadido pelos elementos da civilização. Portanto, o que temos hoje não é mais uma oposição hierárquica, mas uma mescla entre civilização e barbárie.

\footnotetext{
${ }^{23}$ Segundo David Solodkow, Sarmiento teria sido influenciado pelo pensamento do século XIX, marcado por autores como Charles Darwin, Auguste Comte e Henry Spencer. Essas teorias serão utilizadas por Sarmiento para encontrar uma solução para o que ele considerava o "mal constitutivo" da heterogeneidade racial.
} 


\subsection{4}

\section{Razão e Emoção}

A oposição hierárquica entre civilização e barbárie adotada por Sarmiento e outros escritores latino-americanos começou a ser gestada no final do século XVIII na Europa. O vocábulo civilização, como já explicado, é contemporâneo da ideia de progresso e de uma história teleológica. Mas ele também estará intrinsecamente ligado à ideia de ciência. Este aspecto aparecerá nos relatos das viagens de europeus à América nos séculos XVIII e XIX.

Segundo o estudo de Mary Louise Pratt, dois tipos de relatos de viagem são comuns nesse período: aqueles voltados para uma descrição científica do Novo Mundo e os que adotam uma abordagem sentimentalista. De acordo com Pratt, a literatura de caráter científico servia para nomear o outro e mapear o terreno da exploração capitalista sob uma fachada de neutralidade. Este tipo de relato era complementado por descrições românticas e idealizadas que, de uma certa forma, representavam o colonialismo como um projeto edificante.

A literatura científica sobre viagens do século XVIII, assim como as anteriores do século XVI, tem um status epistemológico específico. Pressupõe-se que o relato forneça um caráter neutro e científico sobre o outro. Não se considera a possibilidade de interferência do sujeito no objeto a ser conhecido. Assim, quando o europeu nomeia o americano com os adjetivos canibal, selvagem ou antropófago, ele acredita que esteja dizendo uma verdade sobre o objeto.

Os relatos de viagem de caráter científico geralmente fazem referência às paisagens e aos objetos. Já os nativos são representados como parte da paisagem. O aspecto monológico deste discurso é claro: não há a voz do outro nos textos. Este tipo de relato de viagem tende a naturalizar o mundo ao toma-lo como um dado da realidade. A única tarefa do naturalista viajante seria "descobrir" o que já existe na realidade, classificando e nomeando os objetos.

Por outro lado, as descrições seguem uma estrutura similar à que vimos na concepção de discurso científico de Barbara Jonstone. A naturalização do real ocorre por meio de recursos gramaticais que criam um efeito de certeza, como, por exemplo, a utilização do verbo "ser" conjugado no presente do indicativo. De acordo com Pratt, abundam nestes textos de viagem os verbos de estado: "as 
margens são altas, as aldeias estão situadas, as coisas estão próximas de outras coisas, as ribeiras têm florestas na beira" (2011, p. 152). Destacamos ainda que os verbos estão no presente do indicativo, como havia apontado Jonstone.

Como vimos, essas formas epistêmicas inibem o debate por apresentarem uma estrutura supostamente inviolável. A polifonia presente em toda linguagem é colocada em segundo plano por práticas discursivas monológicas. Nesse contexto, em que o nativo submerge na paisagem, qualquer possibilidade de agência lhe é negada.

$\mathrm{Na}$ análise dos relatos de viagem científicos do século XVIII, Pratt destaca ainda as construções intransitivas, que Jonstone também havia apontado como uma característica do discurso científico. Com a eliminação dos agentes da estrutura do relato, fica mais fácil convencer o interlocutor de que as atividades científicas são objetivas.

A categorização da natureza comum nestes textos obedecia a um "projeto global de classificação" (Pratt, 2011, p. 64), segundo o qual seria possível catalogar e ordenar todas as coisas do planeta. Esta espécie de sonho por um saber total enciclopédico poderia ser comparado ao "mal de arquivo" teorizado por Derrida (ver capítulo 3). Para os viajantes naturalistas, a natureza seria um arquivo que precisaria apenas ser recuperado, nomeado e ordenado. Desta forma, seria possível conhecer a verdade sobre o mundo.

A classificação se estendeu aos habitantes das áreas visitadas, o que faz sentido se considerarmos que estes também eram objetos e coisas do mundo a ser desvendado. O naturalista sueco Carl Von Linné, conhecido em português como Lineu (1707 - 1778), classificou o homo sapiens em seis variedades:

a. Homem selvagem. Mudo e peludo.

b. Americano: moreno, colérico, cabeçudo, amante da liberdade, governando pelo hábito, corpo pintado.

c. Europeu: branco, sanguíneo, musculoso, engenhoso, inventivo, governado por leis, usa roupas apertadas.

d. Asiático: amarelo, melancólico, severo, arrogante, governado pela opinião e pelos preconceitos, usa roupas largas.

e. Africano: negro, astucioso, preguiçoso, negligente, governando pelos caprichos. 
f. Anões e Gigantes.

O esquema classificatório acima exposto realiza uma hierarquização racista dos homens, atribuindo a cada grupo um comportamento que seria derivado de seu fenótipo. Em outras palavras, haveria uma relação intrínseca entre o aspecto físico e qualidades morais, psicológicas, intelectuais e culturais. O europeu estaria associado a qualidades positivas, que denotariam um estágio civilizado de desenvolvimento. Seriam inventivos, engenhosos e governados por leis.

Em contraste, os outros povos seriam governados pelas emoções: o americano pelo hábito, o asiático pelos preconceitos e o africano pelos caprichos. Subjacente a este esquema, está a oposição hierárquica razão/emoção, em que aqueles que possuem a razão seriam superiores aos demais. Vale notar que o homem selvagem, na visão de Lineu, seria mudo, ou seja, estaria num estágio inferior ao do bárbaro, que, pelo menos, poderia balbuciar. De qualquer forma, tanto quanto o bárbaro, ele não teria capacidade de usar a linguagem. Os americanos, asiáticos e africanos estariam num patamar civilizatório um pouco superior ao do homem selvagem, sendo capazes de utilizar a linguagem, ainda que de forma emotiva. A distância desse povos não europeus da civilização explicaria seu excesso de emotividade e a falta de controle sobre seus impulsos. Desta forma, o americano seria colérico, cabeçudo e amante da liberdade; o asiático, melancólico, severo e arrogante; e, por fim, o negro se mostraria astucioso, preguiçoso e negligente.

É importante destacar que a classificação de Lineu não faz distinção entre americanos do Norte e do Sul. Os "americanos" constituiriam um único povo. A dicotomia civilizado/bárbaro destinava-se ao Novo Mundo, que incluía a América do Norte e a América Latina, ambas vistas como o "Outro" da Europa.

Os norte-americanos tiveram de construir seu "outro" para poder se apresentar como parte do Ocidente. Este processo de constituição da identidade norteamericana se deu tanto no momento da colonização, em que o outro era o indígena (Campbell), quanto posteriormente, quando o outro passou a ser o latinoamericano (Feres Júnior).

Em “A história do conceito de 'Latin America' nos Estados Unidos”, João Feres Jr. mostra como se deu a construção das identidades e da oposição hierárquica entre norte-americano e latino-americano. No verbete "Latin" do Oxford English Dictionary (elaborado no século XX), o latino é caracterizado como "or- 
gulhoso, passional, impetuoso, exibido e, algumas vezes, um pouco arisco" (Feres Jr., 2004, p. 43).

Nesta cadeia de significantes, a lógica da diferença atua no sentido de essencializar duas identidades: a do latino-americano e a do norte-americano. Os termos orgulhoso, passional, impetuoso, exibido surgem associados ao latino. Já o significante "norte-americano" atua no verbete como uma ausência. Assim como o viajante do século XVIII, ele é um sujeito supostamente neutro que nomeia e diz uma verdade sobre o "outro latino-americano". Há um silêncio sobre o que seria o norte-americano, mas este silêncio não deixa de ter um caráter estruturante da cadeia, uma vez que é em oposição a um norte-americano racional, disciplinado, correto e com caráter que podemos falar de um latino-americano impulsivo.

Em resumo, o norte-americano tenta se diferenciar do latino-americano reproduzindo termos semelhantes àqueles que os europeus empregavam para se referir aos "americanos" de uma forma geral. Neste processo, o norte-americano absorve as características europeias de racionalidade, inventividade e respeito às leis. O estudo de Feres Júnior aponta para uma questão já salientada por Doty: a "ligação ocidental" (Western Bond) entre Estados Unidos e Europa (ver capítulo 2).

Embora não haja consenso sobre a origem do termo América Latina ${ }^{24}$, sabemos que ele se consolidou em meados do século XIX, como parte da estratégia de Napoleão III de liderar as nações latinas. Portanto, sua origem está relacionada a um projeto imperialista francês num momento de expansão do domínio anglosaxão no continente. No contexto cientificista e racista do século XIX, a ideia napoleônica era de que haveria uma "raça latina" que deveria permanecer unida. A semelhança latina justificaria o imperialismo.

Segundo Mary Louise Pratt, na primeira metade do século XIX, ocorreu uma reinvenção da América pelos europeus, processo que esteve ligado "às possibilidades expansionistas para os capitais, a tecnologia, as mercadorias e os siste-

\footnotetext{
${ }^{24}$ Para Arturo Ardao, em sua obra Gênese da Ideia e nome da América, e Ignácio Hernando de Larramendi, em seu livro Utopia da Nova América, o termo foi criado pelo colombiano José Maria Torres Caicedo no século XIX. No entanto, Fernando Del Paso, em Notícia do Império, afirma que a expressão "América Latina" é uma concepção de Michel Chevalier, ideólogo da teoria pan-latina de Napoleão III (apud Pratt).
} 
mas de conhecimento europeus" (2011, p. 213). Portanto, a estratégia pan-latina de Napoleão III na segunda metade daquele século significava já uma reação a essa "corrida" dos países europeus para a América Latina. Napoleão tentava reservar para si o continente disputado por europeus.

A acepção "napoleônica" da América Latina trazia consigo uma conotação positiva, que, inclusive, foi apropriada posteriormente por escritores latinoamericanos. O mexicano José de Vasconcelos, em seu livro Bolivarismo e Monroísmo (1929), pensava "América como o continente criador de uma raça superior, a raça cósmica, que era a fusão final de todas as raças” (apud Bruit, 2000, p. 7).

No entanto, o significado de "latino-americano" sofrerá deslocamento no contexto norte-americano. O termo deixa de representar uma raça superior para se transformar exatamente no contrário, numa raça degenerada. É desta forma que os Estados Unidos tentam se aproximar dos europeus, relegando os latinoamericanos a uma posição secundária no hemisfério ocidental.

No quadro abaixo, podemos verificar que a oposição hierárquica do século XVI ocorria entre o europeu e o indígena (todos os americanos, sem distinção entre norte-americano e latino-americano), enquanto a oposição dos séculos XIX e XX se dará entre o norte-americano e o latino-americano. No entanto, as características do norte-americano fazem parte do mesmo campo semântico das qualidades atribuídas ao europeu no século XVI. Entende-se que quem é racional e disciplinado é também civilizado.

$\begin{array}{lc}\text { Americano/século XVI } & \text { Europeu/século XVI } \\ \text { irracional } & \text { civilizado } \\ \text { bruto } & \text { cristão } \\ \text { passional } & \text { racional } \\ \text { torpe } & \text { humanista } \\ \text { violento } & \text { linguagem } \\ \text { desprovido de humanidade } & \\ \text { não-cristão } & \\ \text { canibal } & \\ \text { bárbaro } & \\ \text { grunhido } & \\ \text { sensual } & \end{array}$


Latino-americano/século XIX

Orgulhoso

\section{Passional}

Impetuoso

Exibido
Norte-americano/século XIX

\author{
racional \\ disciplinado \\ correto \\ com caráter
}

Pelo quadro acima, percebe-se que as características atribuídas aos "americanos" de uma forma geral são transferidas para o latino-americano, enquanto as qualidades dos europeus são herdadas pelos norte-americanos. A palavra racional, por exemplo, é comum a europeus e norte-americanos. Mas esta semelhança ocorre às custas da atribuição de características negativas aos latino-americanos, que passarão a ser chamados de passionais. O termo passional, como podemos ver no diagrama, também já havia sido utilizado no século XVI para se referir indistintamente a todos os americanos.

A distinção entre norte-americanos e latino-americanos permite que o termo "norte-americano" se desloque para a cadeia de significantes que atribuía qualidades aos europeus, daí a semelhança de atributos dos dois quadros da direita. Ao mesmo tempo, o termo latino-americano permanece atado a uma cadeia de significantes que o associa ao bárbaro, ao canibal, ao violento e desprovido de humanidade. Nas cadeias de significantes analisadas, a oposição hierárquica europeu/canibal transforma-se na oposição norte-americano/latino-americano, sendo que o norte-americano perpetua as características do europeu e o latino-americano preserva a dos "canibais".

É curioso notar que, ao se diferenciar do latino-americano e aproximar-se do europeu, o norte-americano assume a classificação de Lineu sobre os povos. Isto pode ser constatado no estudo de Roxane Lynn Doty sobre o discurso americano sobre as Filipinas nos anos 50, que se baseava na crença dos diferentes tipos de mentalidade. Os asiáticos seriam mais emocionais do que os norte-americanos. Uma das metáforas mais utilizadas pelos norte-americanos ao se referirem aos 
filipinos era a parental. Os filipinos eram vistos como crianças que ainda precisariam ser cuidadas pelos norte-americanos, o que justificaria a intervenção e a dominação. Uma outra distinção era aquela entre a "boa criança" e a "criança problema", dicotomia que se desdobra em "bom aluno, disciplinado" e "mau aluno". Um terceiro grupo de oposições associado aos dois anteriores ocorre entre caos e ordem. As Filipinas foram construídas como um lugar ameaçado pela desordem e que, por isso, necessitava da ordem trazida pela administração norte-americana.

A teoria dos tipos de mentalidade ressurge de tempos em tempos. Em 1962, o historiador francês Robert Aron chegou a sugerir "que os muçulmanos careciam do 'gosto por ordem e clareza' que herdamos de Descartes. (...) A verdadeira natureza do pensamento muçulmano reaparece - mais emocional e sentimental do que dialético e lógico" (apud Doty, 1996, p. 88) ${ }^{25}$.

Essas dicotomias - adulto/criança, professor/aluno, bom aluno/mau aluno, caos/ordem - têm semelhanças com outras utilizadas por europeus para se referir aos latino-americanos, como veremos a seguir.

Durante o século XIX, o romantismo europeu ${ }^{26}$ influenciou a forma como os europeus se referiam aos americanos do Sul. Os viajantes do século XIX, destaca Pratt, reinventaram a América como uma Natureza romântica e idealizada, como já haviam feito os escritores do século $\mathrm{XVI}^{27}$. No período pós"descobrimento", a América era representada como um paraíso, um mundo primordial, um espaço intemporal e vazio. Também não teria uma organização social e econômica e, por isso, seria um lugar sem história. Em suma, a América possuía um espaço e um tempo vazios que precisavam ser preenchidos pelos europeus.

No século XIX, tal como ocorria nos relatos do XVI e do XVIII, o discurso europeu sobre a paisagem e a natureza desterritorializava os povos indígenas. Eles eram separados "dos territórios que alguma vez dominaram e nos quais conduzem sua vida" (Pratt, 2001, p. 252). Em um de seus comentários, o naturalista alemão

\footnotetext{
${ }^{25}$ No século XXI, a crença sobre tipos de mentalidade continua firme. Recentemente, os Estados Unidos se declararam preocupados com seu sistema educacional, que estaria perdendo em qualidade para o da China. A causa do sucesso chinês estaria relacionada à cultura chinesa, que prezaria a disciplina e a racionalidade. Ainda sobre este aspecto, lembramos o comentário de Amarty Sen de que não há características essenciais que possam ser atribuídas a um grupo ou outro de pessoas.

${ }^{26} \mathrm{O}$ romantismo não é endógeno à Europa, pois foi construído a partir da experiência latinoamericana.

${ }^{27}$ No século XVI, a figuração e as alegorias podiam ocupar os espaços vazios nas cartas geográficas. O mito da ilha Brasil pressupunha também um espaço vazio, que poderia ser ocupado pelos colonizadores.
} 
Alexander von Humboldt dirá que os ameríndios são "restos de hordas indígenas" (Ibidem, p.250).

Se Humboldt e outros naturalistas deixavam o nativo "fora da paisagem", um outro tipo de relato da mesma época se encarregará de complementar esta descrição: o nativo faz parte da paisagem e, por isso, não a explora devidamente.

Diante da independência de vários países na América do Sul e da decorrente incerteza das empresas coloniais europeias, surge a chamada querelle d'Amérique, cujas dimensões ideológicas se concentravam na ideia de ligar a América à Europa numa relação de negatividade. Os debates tentavam mostrar como os dois continentes estavam intrínseca e naturalmente ligados.

Mas um outro discurso sobre a América do Sul e o latino-americano se consolida nesse contexto, favorecendo os interesses de uma vanguarda capitalista europeia ansiosa por retomar seu controle sobre o continente americano. A sociedade hispano-americana como um todo - criolos, nativos, mestiços - começa a ser descrita como atrasada, indolente e incapaz de explorar os recursos naturais.

A visão do abandono, que até então era aplicada à Natureza, "uma natureza exuberante e intocada", se estenderá à própria sociedade. Esta é tão negligente que não consegue melhorar a natureza. De acordo com o francês Gaspar Mollien, "Grande parte das terras estão sem cultivo; no entanto, poderiam produzir boas colheitas se os habitantes fossem menos indiferentes. Não há estímulo que os faça sair de seus indolentes hábitos e de sua rotina habitual” (Mollien apud Pratt, 2011, p. 280).

Esta descrição do latino-americano pelo europeu deve ser compreendida dentro do quadro de referência cultural da época, em que civilização era associada ao capitalismo. Nos discursos europeus sobre a América Latina, temos a presença da diferença colonial, subjacente da oposição hierárquica civilização/barbárie, em que o termo civilização virá associado a progresso, produtividade e capitalismo.

O modelo capitalista era o do empreendedor que pautava suas ações por conceitos como eficiência, produtividade e otimização do tempo. Sob o ponto de vista do desenvolvimento da sociedade, o paradigma maximizador e acumulativo do capitalismo era considerado superior ao modo de subsistência por ser mais racional. Ao contrário do americano, o europeu sabia como racionalizar e maximizar a produção. 
Retoma-se aqui a dicotomia razão/emoção que já havia estruturado o discurso europeu do século XVI. Os primeiros a descrevem a natureza exuberante do Novo continente também fizeram referência aos habitantes que pareciam não fazer questão de extrair algo da natureza. No século seguinte, a tese de John Locke sobre o valor do trabalho daria consistência lógica à expropriação territorial. No estado de natureza, explica Locke, tudo o que a natureza produz é de todos. No entanto, se um homem se dá ao trabalho de recolher a água de um rio, aquela água contida no pote passa a ser sua propriedade. É esta narrativa sobre trabalho e propriedade que embasará os capitalistas interessados no desenvolvimento latinoamericano.

Na lógica da vanguarda capitalista, inspirada por Locke, os latinoamericanos não maximizam a produtividade da terra porque são indolentes e preguiçosos. Logo, o desenvolvimento do continente latino-americano dependeria da contribuição dos europeus, que ensinariam os habitantes locais a se tornarem mais racionais e disciplinados, capazes de trabalharem a terra para, assim, dela se tornarem proprietários.

Em outras palavras, o latino-americano seria uma criança - espontâneo, sem controle sobre si, emocional - que teria de ser conduzida pelos europeus, povos já amadurecidos e experientes no contato com a civilização. Ao mesmo tempo, a produção agrícola baseada na subsistência era vista pelos capitalistas como um "caos", uma desorganização completa da produção. Somente os métodos racionais, o planejamento e a otimização do tempo, devidamente ensinados pelos europeus, poderia dar alguma “ordem” à atividade agrícola.

É o suposto atraso da América que legitima as intervenções da vanguarda capitalista. Ideologicamente, a tarefa da vanguarda consiste em reinventar a América como atrasada e descuidada, codificar suas paisagens e sociedades não capitalistas como evidentemente necessitadas da exploração racionalizada que chegava com os europeus (Pratt, 2011, p. 283).

A oposição assimétrica entre capitalismo e atraso pressupõe uma concepção de temporalidade linear que perpassa os diversos discursos que temos visto.

No discurso europeu dos séculos XVI e XVII, a América estava localizada num tempo a-histórico, ou seja, os indígenas ocupariam um lugar fora da História. No discurso dos séculos XVIII e XIX, o continente se encontrava num lugar pelo 
qual os europeus já teriam passado. Consequentemente, os americanos eram considerados atrasados em relação aos europeus. A diferença cultural era pensada ora como primitivismo ora como atraso, transformando-se também em uma diferença temporal.

A diferença temporal será um dos pontos fundamentais da teoria da modernização no século XX, que estabelecerá a oposição assimétrica entre desenvolvido e atrasado. Para Inayatullah e Blaney, a teoria da modernização silencia a diferença cultural ao transformá-la em diferença temporal. É como se os teóricos da modernização estivessem dizendo aos atrasados que sua diferença cultural é apenas uma questão de defasagem temporal, que logo será abolida pelo progresso e pela modernização. Classificá-la como atraso é uma maneira de torná-la provisória, uma "cultura com os dias contados". É também uma estratégia que clama pela intervenção e pela ajuda, pois, o "atrasado" não é, como o Calibán de Shakespeare ou o indígena de Sepúlveda, um caso sem solução.

O "atrasado" é aquele que pode aprender e ser curado. Era assim que o europeu do século XVI, pelo menos os seguidores de Bartolomeu de las Casas, justificava a colonização. Num outro contexto, os países desenvolvidos legitimavam suas ações no século XX com o argumento de que era seu dever ajudar os atrasados a alcançarem o mesmo nível de desenvolvimento dos ricos. Portanto, a teoria da modernização produzia uma concepção de história teleológica na qual o ponto de chegada já estava definido de uma vez por todas pelas sociedades capitalistas desenvolvidas.

O contexto em que surgiu a teoria da modernização começou a se desenhar após a Segunda Guerra Mundial. Em 1949, o presidente Truman declarou que mais de metade dos povos do mundo vivia em condições precárias e que "sua pobreza é um handicap" (apud Feres Jr., 2004, p. 93), ou seja, neste período a pobreza ocupa o lugar que antes era destinado aos doentes não-cristãos no século XVI. E a cura para a pobreza também seria proporcionada pelo Ocidente, da mesma forma que a cura para a doença do não-cristão era a civilização cristãocidental. Diz Truman: “Acredito que devemos tornar disponíveis a esses povos pacíficos os benefícios de nossa reserva de conhecimento técnico, para ajudá-los a realizar seus anseios por uma vida melhor" (loc. cit, grifo nosso). Note-se que os 
povos pacíficos, ou seja, os potenciais bons alunos, são os receptores naturais da ajuda oferecida pelos mais desenvolvidos ${ }^{28}$.

Retornamos aqui à questão mencionada na abertura da seção 4.3, qual seja, o fato de as declarações reproduzirem práticas discursivas semelhantes às usadas nas relações entre Europa e América Latina nos últimos séculos. As políticas de ajuda externa dos anos 60 criticadas por Doty foram elaboradas tendo a teoria da modernização como pano de fundo intelectual. As mesmas teses desta corrente intelectual aparecem no discurso sobre a ajuda externa, como, por exemplo, a crença de que a pobreza constitui um perigo.

Por outro lado, tanto a política de ajuda externa quanto a teoria da modernização pressupõem a oposição hierárquica professor/aluno, que vimos estar presente também nos discursos sobre o indígena, o bárbaro, o habitante do Novo Mundo, os hispano-americanos. Com exceção do selvagem ou canibal incapaz de aprender, todas as oposições hierárquicas que vimos acima partem do princípio de que o termo inferior da oposição possa - e deva - vencer a distância temporal e civilizacional que o separa do termo superior.

Nas declarações de cúpula, a pobreza volta a ser tratada como uma ameaça à coesão social e, portanto, à associação estratégica. $\mathrm{O}$ modelo professor/aluno também continua sendo apresentado como a solução para este problema. Nos textos das cúpulas, a Europa se refere à América Latina e ao Caribe como o "Outro" que precisa de uma ajuda e de uma solução. Esta oposição fica mais clara em outros discursos sobre o processo de integração europeu (ver capítulo 2), que o apresentam como um modelo para outras regiões, em particular para a América Latina e o Caribe. Para o ex-diretor-geral da Organização Mundial do Comércio (OMC) Pascal Lamy, o modelo europeu deveria ser exportado.

As práticas discursivas que construíram as identidades da Europa e da América Latina em diferentes épocas parecem se fixar no ponto nodal da América como um "outro". Os termos associados a esse "outro", no entanto, variaram ao longo do tempo. A análise das oposições hierárquicas nos mostrou como os Estados Unidos incorporaram o discurso europeu sobre um "outro" latino-americano,

\footnotetext{
${ }^{28} \mathrm{O}$ discurso do bom e do mau aluno continua presente em algumas avaliações sobre a África. Países desse continente que receberam ajuda externa e não conseguiram resultados satisfatórios são considerados "maus alunos", "inaptos na aplicação dos recursos" e "ineficientes".
} 
confirmando a tese de Doty sobre uma "ligação ocidental" (Western bond) que uniria os Estados Unidos e a Europa.

Os discursos sobre o "outro" são monológicos pois baseiam-se na concepção epistemológica de um sujeito observador que é o único a ter voz sobre o objeto. O monologismo tenta fixar uma essência para o "outro", um fundamento. Neste capítulo, vimos que o pronome "nós" provoca um efeito de monologização. Uma outra forma de criar monologismos é por meio das oposições hierárquicas, nas quais apenas o primeiro termo terá voz. O que ocorre nestes casos é um encobrimento da polifonia, mas não uma eliminação. De acordo com Bakhtin, todo discurso é polifônico, dialógico ou heteroglóssico. Ou seja, sempre há mais de uma voz em jogo.

Pratt chama a atenção para o fato de que mesmo a literatura de viagem, um dos discursos mais claramente monofônicos da historiografia, é perpassada pela polifonia:

Cada relato de viagens tem sua própria dimensão heteroglóssica: seu conhecimento não surge apenas da sensibilidade e do poder de observação de um viajante, mas de interações e experiências usualmente dirigidas e controladas pelos que recebem a visita do viajante" (Pratt, 2011, p.254).

A tradição da literatura de viagens, estreitamente conectada a uma epistemologia positivista, promove um sujeito europeu moderno que seria autosuficiente e monádico. Temos nestes relatos um sujeito capaz de proferir um discurso sobre o outro de forma autônoma, como se este outro não tivesse qualquer poder de influência sobre o sujeito observador. Segundo Pratt, neste tipo de texto, a interação (no caso de Bakhtin, o dialogismo) é transformada num mero traço.

Mas a heteroglossia pode ser verificada na análise de Pratt sobre os escritos de Humboldt. A versão tradicional defende que o romantismo alemão do século XIX teria influenciado a visão de Humboldt sobre a América. Ou seja, um sujeito europeu (Humboldt), influenciado por uma tradição europeia (o romantismo), teria se debruçado sobre o outro americano para produzir conhecimento. No entanto, esta interpretação se revela eurocêntrica quando constatamos que muitas das ideias românticas foram inspiradas pelo contato do europeu com o Novo Mundo. Portanto, não existiria um romantismo endógeno na Europa. 
A tese de Pratt confirma as teorias pós-colonialistas de Aníbal Quijano, Enrique Dussel e Walter Mignolo sobre a formação da Europa. Sem a América, a Europa não teria se formado. Nas palavras de Oswald, sem a América, a Europa não teria a sua declaração de direitos humanos.

Tanto a literatura de viagens quanto os textos das declarações de cúpula se caracterizam por uma monofonia ostensiva e uma polifonia implícita. Ambos supõem falar a partir de um lugar de enunciação neutro, que lhes permitiria fornecer a verdade sobre o mundo.

Como vimos ao longo deste capítulo, a literatura de viagem e as declarações de cúpula utilizam os recursos linguísticos geralmente encontrados em discursos científicos, como a voz passiva e os verbos de estado conjugados no indicativo. Esses expedientes linguísticos comunicam uma certeza sobre a realidade e promovem sua naturalização. Nos relatos de viagem, teríamos uma descrição fiel do Novo Mundo. Já nas declarações de cúpula, conheceríamos uma nova ordem mundial mais justa criada pela associação estratégica.

O cientificismo de alguns relatos de viagem se manifestava na ânsia de classificar e ordenar a natureza para nela interferir. As declarações de cúpula fazem algo semelhante. Dividem e classificam o mundo nos campos da ordem ou da desordem, permitindo que os representantes da ordem intervenham no âmbito da desordem. 


\section{As Migrações na Associação Estratégica}

De todos os temas tratados nas declarações de cúpula entre União Europeia e América Latina-Caribe, as migrações exemplificam de maneira contundente a contradição presente no discurso sobre a possibilidade de uma associação estratégica entre as duas regiões. É no discurso sobre a migração que podemos detectar com mais clareza o tratamento ambíguo conferido pela União Europeia à América Latina. Ora esta aparece como semelhante à Europa, ora como diferente, como o lugar dos rebentos e mutantes, dos "retardatários da civilização" (Santos, 2007, p.50).

A criação de um espaço birregional e uma "comunidade imaginada" entre União Europeia e América Latina-Caribe deveria supostamente garantir o fluxo de migrantes europeus e latino-americanos nesse âmbito. Vimos que a associação estratégica reproduz a dicotomia inside/outside do Estado moderno. O discurso da associação coloca União Europeia e América Latina-Caribe no espaço do inside, opondo-as ao outside, composto pelos "outros" do sistema internacional.

Ora, esta construção de um "nós" que uniria União Europeia e América Latina e Caribe em torno de um mesmo projeto é minada por práticas discursivas e não discursivas utilizadas pela União Europeia para controlar o fluxo de migrantes. Nesse processo, o migrante latino-americano não recebe nenhum tratamento privilegiado pelo fato de sua região fazer parte da associação estratégica. Portanto, ele deixa de constituir o "nós" e se transforma num "outro". Em suma, o latinoamericano, que num primeiro momento fazia parte da comunidade imaginada e encontrava-se no âmbito do "inside”, passa, num segundo momento, a ocupar o espaço do "outside", de onde costumam provir os bárbaros.

Nesse deslocamento do inside para o outside, o latino-americano não se juntaria a todos os outros bárbaros que supostamente ameaçam a Europa? Qual seria então sua especificidade? De fato, o migrante latino-americano não seria o único "bárbaro" com o qual a União Europeia teria de lidar no século XXI nem talvez o mais importante. Migrantes do leste europeu, do Oriente Médio, do Ma 
greb, da África subsaariana ou da Ásia continuam sendo representados, nas políticas de controle migratório da União Europeia, como “outros” indesejáveis.

O que torna a análise da posição do migrante latino-americano especialmente válida para nossa pesquisa é o fato de que ele, ao contrário dos outros migrantes, fazia parte de uma comunidade imaginada na qual era considerado como um semelhante. Ele é aquele que "já esteve dentro um dia” e depois foi repelido e tratado como bárbaro.

Sua identidade é cambiante e depende dos movimentos de aproximação ou afastamento verificados entre a União Europeia e a América Latina-Caribe. O migrante latino-americano será representado como um semelhante do europeu quando a relação entre União Europeia e a América Latina-Caribe ocorrer sob a lógica da equivalência. Ao contrário, o migrante latino-americano transforma-se num "bárbaro" quando a lógica da diferença prevalecer entre UE e ALC. Como vimos, neste momento, a lógica da equivalência se estabelece entre Estados Unidos e União Europeia, formando o Western Bond.

Como discutiremos ao longo deste capítulo, o migrante latino-americano, sobretudo o ilegal, atualiza no século XXI os significantes bárbaro, canibal, antropófago, que apareciam em cadeias de significantes dos séculos XVI e XVII como os termos inferiores de uma oposição hierárquica. Verificamos assim a permanência de oposições hierárquicas entre União Europeia e América Latina ao longo dos séculos.

Pode-se contestar que o migrante ilegal latino-americano não é o único a atualizar esses significantes. De fato, qualquer migrante ilegal poderia hoje ser pensado como a versão contemporânea da figura do bárbaro e do canibal. No entanto, não se trata aqui de analisar todos os “outros bárbaros” da União Europeia, mas aquele que, surgindo num determinado momento como bárbaro, questiona o discurso sobre a associação estratégica entre União Europeia e América LatinaCaribe.

Diante da presença do migrante latino-americano ilegal, criado pelos próprios controles migratórios europeus, a União Europeia não pode continuar sustentando um discurso sobre uma associação estratégica com a região-irmã América Latina e Caribe. A associação estratégica revela-se assim como um projeto europeu destinado tão-só a recuperar e propagar uma Ideia de Europa. Torna-se evidente que a América Latina e o Caribe ocupam uma posição secundária e su- 
plementar numa associação estratégica que é, de fato, a encarnação de um projeto europeu de reposicionamento no sistema internacional.

Como desenvolveremos em outra seção, o potencial contestador do migrante ilegal e, em particular, do migrante ilegal latino-americano para a associação estratégica, está relacionado à questão do fundamento contingente. A associação estratégica é uma comunidade imaginária e, como tal, não possui um fundamento último. Por esta razão, a associação estratégica precisa ser constantemente reafirmada nos documentos das cúpulas. Quando o discurso sobre a associação afirma a semelhança de valores latinos entre União Europeia e América LatinaCaribe, somos levados a crer que esses valores constituem um fundamento da associação. Porém, a presença do migrante ilegal latino-americano irá desestabilizar esse ponto nodal da "naturalidade dos valores latinos" como fundamento da associação. A partir de uma prática articulatória contra-hegemônica, ele mostrará que aquele fundamento é contingente. Nem sempre o europeu verá o latinoamericano como alguém com quem possa compartilhar os mesmos valores.

A presença do migrante ilegal latino-americano revela ainda a fragilidade do argumento sobre uma globalização alternativa conduzida pela Europa. Uma globalização europeia, com fechamento de fronteiras a migrantes, não significaria uma alternativa à globalização atualmente em curso, mas uma reprodução do modelo. Além de contestar a associação estratégica e o projeto de uma outra globalização, o migrante ilegal latino-americano traz em si um potencial de criação na medida em que se apresenta como híbrido. Em vez de uma globalização baseada num projeto eurocêntrico, a globalização sugerida pela figura do migrante latinoamericano é híbrida, sendo que o hidridismo é aqui considerado como indecidibilidade. O lado antropofágico desse migrante latino-americano aponta para a possibilidade de hibridismos, indecidibilidades e aberturas ao outro.

Se, nos séculos XVI e XVII, a Europa produzia um discurso monológico sobre a América, no século XXI vemos a possibilidade de discursos alternativos produzidos por vozes por muito tempo reprimidas. "O reprimido retorna sob outra forma" (Santiago, 2006, p.10). 


\section{1}

\section{As migrações nas declarações de cúpula}

O tema migrações aparecerá em três das seis declarações de cúpula: Guadalajara (2004), Viena (2006) e Lima (2008). O fato de ter ficado ausente do documento assinado em Madri em 2012 não significa, porém, que o assunto esteja fora da pauta. A declaração mais recente não revoga as anteriores, mas forma com estas um acervo sobre os propósitos da associação estratégica.

Como vimos no capítulo 4, a declaração de Guadalajara propõe "um enfoque integral sobre a migração" e "cooperação e conhecimento mútuo das realidades migratórias em ambas as regiões" $(2004$, p.6). Deve-se ter como meta o "respeito dos direitos humanos de todos os migrantes, independentemente de seu estatuto" (loc.cit), ou seja, nenhum migrante poderá ter seu direito violado com a justificativa de que é ilegal ou irregular. O respeito aos direitos humanos dos migrantes impediria qualquer discriminação entre migrantes legais e ilegais.

Aqui é possível perceber uma intertextualidade e polifonia implícitas. O documento de Guadalajara dialoga com textos sobre direitos humanos aprovados pelas Nações Unidas. Não há referência direta a esses documentos nem eles são citados, configurando assim uma polifonia implícita. O "outro" norte-americano também está ausente do documento, porém a declaração não deixa de dialogar indiretamente com as políticas dos Estados Unidos para o tema migratório. Como vimos, a associação estratégica se opõe aos Estados Unidos ao defender, junto com a América Latina e o Caribe, uma ordem internacional mais justa.

As boas intenções continuam a ser enumeradas na declaração, reforçando o discurso de uma associação estratégica promotora de virtudes num sistema internacional inóspito. A migração irregular e o tráfico de seres humanos devem ser combatidos. É necessário avaliar o impacto da fuga-de-cérebros nos países de origem. Reconhece-se a contribuição dos migrantes ao desenvolvimento econômico, social e cultural dos países receptores. E mais: condena-se a violência e a discriminação contra migrantes, sobretudo mulheres e menores. Em resumo, a associação birregional representaria um espaço acolhedor para o migrante.

O documento de Guadalajara apresenta também uma relação de intertextualidade com a "Convenção Internacional sobre a Proteção dos Direitos de Todos os Trabalhadores Migrantes e de suas Famílias”, de 2003. Neste caso, temos uma 
polifonia explícita, dado que a Convenção Internacional é claramente citada e tomada como referencial.

A declaração parece monofônica, produzida por um consenso entre União Europeia e América Latina-Caribe. No entanto, como vimos com Mikhail Bakhtin, mesmo a declaração mais monofônica contém algum grau de polifonia. Existe uma "voz" da América Latina e Caribe que sugere à União Europeia a consideração da Convenção Internacional para Proteção dos trabalhadores migrantes. A polifonia do discurso das cúpulas se manifesta na seguinte passagem:

Os Estados da América Latina e do Caribe signatários da 'Convenção Internacional sobre a Proteção dos Direitos de Todos os Trabalhadores Migrantes e de suas Famílias' enfatizam a importância que atribuem a esta Convenção no âmbito do sistema internacional de proteção dos direitos humanos (Convenção Internacional, 2003).

Antes de continuarmos, um breve histórico sobre a Convenção se faz necessário. O documento foi adotado pela resolução 45/158, de 18 de dezembro de 1990, da Assembleia Geral da Organização Internacional do Trabalho (OIT) e entrou em vigor em $1^{\circ}$ de julho de 2003. A convenção é o documento internacional mais avançado no tema migratório, pois defende a dignidade do migrante independentemente de sua condição migratória. Nesse sentido, ela privilegia o interesse do migrante em detrimento do dos Estados nacionais. Como vimos acima, esta mesma formulação aparecerá na Declaração de Guadalajara: "Respeito dos direitos humanos de todos os migrantes, independentemente de seu estatuto" (loc. cit.).

A Convenção Internacional não conseguiu aprovação unânime. A tendência é que países emissores de trabalhadores migrantes aprovem e ratifiquem a Convenção e países industrializados receptores a rejeitem. Na América Latina e Caribe, 14 países ratificaram o documento: Argentina, Bolívia, Chile, Colômbia, Equador, El Salvador, Guatemala, Guiana, Honduras, México, Paraguai, Peru, Nicarágua e Uruguai. Dos 27 países da União Europeia, nenhum ratificou a Convenção da OIT. Na Convenção Internacional para Trabalhadores Migrantes, a polifonia se explicita no momento da assinatura e da ratificação. Nota-se a discrepância de pontos de vista entre os países desenvolvidos e os em desenvolvimento. 
A declaração de Guadalajara visa a combater a migração irregular e o tráfico de seres humanos. No entanto, esquece-se que estes dois fenômenos são criados pelo fato de o mundo estar dividido em Estados nações. Ou seja, só podemos falar em migração irregular porque o Estado decide entre o legal e o ilegal, o regular e o irregular. Sem Estado e a instituição de uma ordem jurídica, não é possível distinguir entre o regular e o irregular. Da mesma forma, o tráfico só existe porque a mobilidade é vedada pelo Estado. A distinção entre legal e ilegal realizada pelo Estado cria o contingente de migrantes ilegais que será alvo dos traficantes.

Devemos lembrar que toda migração no "estado de natureza" tinha um caráter legítimo, já que "originariamente ninguém tem o direito mais do que o outro de estar em um determinado lugar da Terra" (Kant, 2004, p.51). No entanto, a divisão do mundo em Estados impôs a distinção entre o cidadão nacional e o estrangeiro.

De acordo com esta narrativa contratualista sobre a formação do Estado moderno, o migrante é o selvagem ou bárbaro que age como se ainda estivesse no estado de natureza e considerasse qualquer lugar da terra passível de ocupação.

$\mathrm{Na}$ prática, a tentativa de combater a migração irregular significa maior controle do fluxo migratório, mais restrições aos migrantes, mais exigências de vistos, comprovação de renda ou grau de instrução.

A distinção entre migração regular e irregular acaba por gerar uma classificação dos migrantes em bons (os regulares, com visto, com renda, com instrução) e maus (os ilegais, sem documentos, sem recursos). Os bons seriam os turistas, civilizados o suficiente para respeitar a ordem internacional de Estados nacionais e se munir de um visto antes de entrar no território alheio. São aqueles, como veremos mais adiante com Kant, que estão dispostos apenas a visitar o território alheio, sem tentar nele residir. Os maus migrantes seriam os vagabundos e bárbaros, que insistem em ignorar o Estado civil e uma ordem internacional nele baseada.

O combate ao tráfico de seres humanos também se reveste de um aspecto nobre. Porém, a discussão se limita à solução de um problema imediato (problemsolving) e não aborda as condições de possibilidade que permitiram que viéssemos a falar em tráfico de migrantes. O discurso humanitário dos Estados e organizações internacionais sobre a necessidade de combater o tráfico de pessoas silen- 
cia sobre o fato de que esse tráfico foi criado justamente por conta das regras restritivas da circulação prevalecentes hoje no sistema internacional.

No discurso oficial das cúpulas, a migração ilegal é a "causa" das medidas de segurança na fronteira. Contudo, é a vigilância e o fechamento das fronteiras que "causam" a migração ilegal. Nota-se aqui uma inversão da oposição hierárquica entre causa e efeito. Supomos que as causas têm uma prioridade lógica e temporal em relação aos efeitos, ou seja, as causas produzem efeitos. Porém, a desconstrução mostra que o efeito é o termo originário, pois, se não houvesse o efeito, não indagaríamos sobre as causas. Assim, o efeito pode ser apontado como a causa da causa. A desconstrução do discurso sobre migrações mostra como este discurso mina a própria base que o sustenta.

A declaração de Viena reforça o discurso de Guadalajara sobre o combate à migração irregular e ao tráfico de seres humanos. Neste aspecto, os textos dessas duas cúpulas estão numa relação de intertextualidade com documentos da ONU sobre o assunto. As políticas da associação estratégica para migração irregular e tráfico de migrantes também dialogam com políticas norte-americanas para o tema. Portanto, no tema migração irregular e tráfico de migrantes, a associação estratégica se aproxima dos Estados Unidos, contrariando seu propósito inicial de diferenciar-se das políticas norte-americanas para criar uma ordem internacional alternativa.

No início do século XX, ainda se discutia a possibilidade da migração livre, com base na experiência do século XIX. Norman Angell descreveu sua migração para os Estados Unidos em 1890 nos seguintes termos: "Eu não tinha passaporte, permissão de saída, visto, número de cota, e nada me pediram quando cheguei aos Estados Unidos" (Angell apud Postrel, 1993, p.1). O controle de fronteiras começou a ser praticado durante a Primeira Guerra Mundial por motivos de segurança e, passado o conflito, foi incorporado à práticas dos Estados. A Liga das Nações realizou uma conferência em 1920 sobre passaportes, seguida de outras duas, em 1926 e 1927. Além dos passaportes, os países começaram a exigir vistos de entrada, com especificação do tempo de permanência no país.

Jonathon Moses lembra que a nova ordem internacional instituída após a Segunda Guerra previa o livre comércio de mercadorias, serviços e investimentos, mas não havia "nenhum Código de Conduta Internacional sobre a natureza e o escopo das restrições migratórias; restrições migratórias eram consideradas assun- 
to de soberania nacional (mas não a taxa de câmbio)" (2006, p. 53). Esta tendência perdura na contemporaneidade, quando vemos a defesa da circulação de mercadorias por parte dos liberais ser acompanhada por um silêncio em relação à livre circulação de pessoas. Nos Estados Unidos, por exemplo, o Tea Party é contra qualquer liberalização da fronteira.

A expressão "migração livre" não faz mais parte do nosso quadro de inteligibilidade. Na formação discursiva contemporânea, o significante "migração" agora aparece numa cadeia ao lado de "irregular", "controle", "fronteira", "vigilância", "ameaça", "tráfico", "segurança", “crime”. O ponto nodal formado nessa prática articulatória hegemônica parece difícil de ser desestabilizado. No discurso hegemônico, a migração surge como um problema que deve ser resolvido por medidas de segurança adotadas pelo Estado. Entretanto, vimos (capítulo 3) que a fixação do ponto nodal jamais é definitiva ou completa. A dimensão do vazio permite a desestabilização do ponto nodal e a abertura.

Em 2008, a Declaração de Lima volta a tratar de migrações, mas introduz um elemento ausente dos textos de Guadalajara e Viena: a importância dos "laços históricos e culturais que sempre existiram entre os países latino-americanos e caribenhos e as nações da União Europeia, baseados no impacto positivo dos fluxos de migração em ambas as direções" (2008, p.9). No item destinado às migrações, a declaração de Lima enfatiza a presença de um "nós", que, como vimos, produz um efeito monológico, como se União Europeia e América Latina estivessem representadas por uma única "voz". O texto baseia-se numa suposta comunhão de ideias entre e sobre as duas regiões. O trecho destacado, "laços históricos e culturais que sempre existiram", tem um efeito "naturalizador" das relações entre União Europeia e América Latina-Caribe. Dizer que os laços históricos e culturais sempre existiram significa eliminar um passado de conflitos e colonização entre as regiões. Significa ignorar a exploração material e a colonialidade do saber que marcaram o "encontro" entre Europa e América. Significa ainda esquecer que os laços históricos e culturais foram construídos por meio de oposições hierárquicas que estiveram presentes em diversos momentos da relação.

Note-se que a afirmação "sempre existiram" tem um caráter impositivo, como costuma acontecer em declarações e manifestos. Como vimos no capítulo 4 , tal construção de frase reforça o monologismo do discurso e desestimula o questionamento. A declaração de Lima inventa e tenta impor uma memória das relações 
entre UE e América Latina, uma memória que seria a mesma em todos os tempos (laços que "sempre existiram").

O documento elaborado em Lima nos remete a uma experiência semelhante ocorrida no século XIX: a querelle d'Amérique. Como vimos no capítulo 4, a querelle representou uma tentativa europeia de se vincular à América do Sul no contexto da independência dos países sul-americanos, que então poderiam se voltar para os Estados Unidos. O discurso da querelle enfatizava que os dois continentes estavam naturalmente ligados. Naquele momento, o "nós" englobava a União Europeia e a América Latina e o Caribe enquanto o "outro" era representado pelos Estados Unidos. A ingerência dos EUA na América Latina e Caribe era vista como uma excrescência pelos europeus. Qualquer interferência dos EUA na América Latina poderia ameaçar o vínculo natural entre Europa e América Latina e Caribe. Em suma, o documento da cúpula de Lima reproduz uma prática discursiva sobre a naturalidade da relação UE-América Latina-Caribe.

Contudo, esse monologismo criado pelo "sempre existiram" e pela querelle d'Amérique não está imune à contestação. Embora o monologismo desestimule o questionamento, ele não tem como evitá-lo, pois, o ponto nodal criado pelo discurso monológico é desafiado por outras vozes. No caso dos "laços históricos sempre existiram" e da querelle d'Amérique, a desestabilização do ponto nodal vem justamente dos grupos não ligados à latinidade.

Outro ponto a ser destacado é o "impacto positivo dos fluxos migratórios em ambas as direções" (loc. cit). Como vimos destacando, os países não têm essa visão otimista sobre o potencial da migração. Os controles de fronteiras têm se tornado cada vez mais comuns. No mesmo ano da declaração de Lima, o Parlamento Europeu aprovou a Diretiva do Retorno (que veremos na próxima seção), uma lei imigratória extremamente restritiva e que prevê prisão e deportação de migrantes ilegais. Portanto, o discurso de Lima é confrontado pela Diretiva do Retorno. Em Lima, a União Europeia e a América Latina e o Caribe - o "nós" monofônico - reconhecem o impacto positivo da migração, mas esta unidade de propósitos entre as duas regiões é interrompida pela Diretiva do Retorno, que as colocará em lados opostos. A diretiva revela que a UE adota uma posição muito mais restritiva à migração do que aquela esposada por América Latina e Caribe.

A “administração ordenada dos fluxos migratórios" (loc. cit) parece um eufemismo para um dispositivo biopolítico que visa a controlar o fluxo populaci- 
onal. Em outros termos, a tentativa de ordenar o fluxo migratório supõe que este seja sinônimo de caos, desordem, ameaça. A migração é vista como potencialmente perigosa quando não controlada.

É interessante notar que o texto nega exatamente aquilo que pretendia afirmar. O objetivo inicial seria a criação de uma associação estratégica como o espaço da ordem, da prosperidade, do progresso. Contudo, o propósito de regular a migração entre as duas regiões pressupõe que exista aí, no próprio seio da associação estratégica, um fluxo potencialmente perigoso. Os laços históricos evocados não são suficientes para liberalizar a migração entre a União Europeia e a América Latina e o Caribe. Ao contrário, a cooperação e o diálogo na questão migratória visam tão-só a limitar o fluxo.

Deparamo-nos então com outro paradoxo da declaração de Lima. O "nós" aparece exaustivamente no texto, criando a ilusão de uma comunidade UEAmérica Latina-Caribe e de um vínculo natural que remete à querelle d'Amérique. Entretanto, o controle migratório coloca o latino-americano na posição de um "outro" bárbaro, não ocidental, não civilizado. Como lembrou Wanderley Guilherme dos Santos, a América Latina ainda é um lugar "habitado por mutantes, rebentos da transplantação de estoques europeus a regiões inóspitas à civilidade, retardatários da civilização" (2007, p. 50).

Se o latino-americano passa de "semelhante" (por conta dos laços históricos) a "mutante", paralelamente os Estados Unidos deixam de ser o "outro" para se tornarem o "companheiro transatlântico". As lógicas de aproximação e afastamento entre a União Europeia e a América Latina manifestam-se concomitantemente no mesmo texto. Podemos assim dizer que a aproximação e o afastamento entre as duas regiões não é um resultado de causas externas e econômicas, mas de contradições presentes nas práticas articulatórias. O discurso sobre as migrações nas reuniões de cúpula possui duas vertentes. Por um lado, há o acolhimento, a defesa dos direitos humanos e a visão do latino-americano como um semelhante que compartilha os mesmos valores. Por outro lado, o migrante latino-americano ainda é o bárbaro, o mutante, o canibal e sua entrada no bloco europeu precisa ser monitorada e vigiada. 


\section{2 \\ O Western Bond e a migração latino-americana}

Embora o nosso objetivo neste capítulo seja entender as implicações do fluxo migratório entre Europa e América Latina-Caribe para a associação estratégica, não podemos deixar de notar que a migração de latino-americanos para os Estados Unidos supera a migração de latino-americanos para a Europa. No entanto, o ponto que pretendemos destacar não é quantitativo, pois está relacionado ao Western Bond, a ligação ocidental que surge entre Europa e Estados Unidos quando estes se opõem à América Latina e ao Caribe. No tema migratório, as práticas discursivas dos Estados Unidos e da América Latina sobre o migrante latinoamericano são semelhantes, pois o latino-americano se transforma no "outro" bárbaro, com características muito diferentes daquelas consideradas naturais no europeu e no norte-americano.

Estas duas correntes migratórias - da América Latina para os Estados Unidos e da América Latina para a Europa - são tradicionalmente explicadas em termos de diferença de desenvolvimento entre o país receptor e o país de origem do migrante. De uma certa forma, a abordagem do "gap de desenvolvimento" pressupõe uma história linear e sequencial na qual as nações seguiriam o caminho para o desenvolvimento. Como este desenvolvimento é travado, em alguns países, por crises econômicas, políticas ou por atavismos culturais, os que se encontram nestes países migram para os países ditos avançados. Nesta concepção, o migrante latino-americano que chega à Europa ou aos Estados Unidos é considerado um ser racional e autônomo que migra após realizar um cálculo de custo e benefício. $\mathrm{Ou}$ seja, verdadeiros parasitas que apenas se servem do país de acolhida sem oferecerem nenhuma contrapartida.

Paradoxalmente, nem todos nestas regiões receptoras de imigrantes latinoamericanos os percebem como racionais. Ao contrário, nos discursos norteamericanos e europeus mais radicais, os imigrantes latino-americanos costumam ser representados como "emocionais", "preguiçosos" e "indisciplinados".

Este discurso reproduz a tese sobre uma "subjetividade subsdesenvolvida" (Mohanty apud Escobar, 1995, p.9), presente em trabalhos da segunda metade do século XX dedicados ao desenvolvimento. Escobar lembra que a teoria sobre o 
desenvolvimento pressupunha que a subjetividade racional moderna dos europeus seria capaz de transformar a subjetividade subdesenvolvida da América Latina.

Nos Estados Unidos, o latino-americano é associado a uma série de personagens em filmes e livros: o mecânico, o mexicano preguiçoso, o amante latino, a empregada doméstica, o drogado, o mafioso ... Nos anos 40, os mexicanosamericanos foram representados como criminosos em romances policiais e jornais. No entanto, como lembra Octavio Paz em "Labirinto da Solidão", o mexicano-americano, também chamado de pachuco, soube associar sua imagem à de malandro, dândi e conquistador. Os ternos do pachuco ficaram conhecidos como zoot suits e se tornaram moda na América. Em "Greasers and Gringos", Steven W. Bender mostra como o termo "greaser" (oleoso, graxeiro, engraxate) era frequentemente atribuído aos latinos em vários filmes. No romance "Tortilla Flat", John Steibeck também representa os latinos como preguiçosos e bêbados.

Reproduzimos abaixo o quadro que analisamos no capítulo anterior e que mostra a distinção que começou a ser feita no século XIX entre norte-americanos e latino-americanos.

\section{Latino-americano/século XIX}

\section{Norte-americano/século XIX}

Orgulhoso

Passional

Impetuoso

Exibido

\section{racional}

disciplinado

correto

com caráter

Ora, os termos utilizados no século XX pelos norte-americanos para se referirem aos latino-americanos - emocionais, preguiçosos, indisciplinados, latin lover - poderiam estar perfeitamente na primeira coluna, que trata das características do latino-americano no século XIX. No capítulo 4, podemos ver que a coluna "latino-americano/século XIX" é também alimentada pela coluna "Americano/século XVI". Nesta, o americano (tanto o do norte quanto o do sul) era representado como irracional, passional, canibal e sensual, entre outros adjetivos. Em 
suma, os adjetivos atribuídos no século XVI aos canibais reaparecem no século XX na caracterização dos migrantes latino-americanos.

Como lembra Fernando Coronil, a América Latina tem sido descrita como "inferior em diferentes períodos históricos, de acordo com a tipologia dominante" (2011, p. 246). Consequentemente, poderíamos dizer, o latino-americano também é submetido ao mesmo processo de inferiorização.

Esses estereótipos permanecem em alguns discursos norte-americanos contemporâneos, como o do Tea Party e o de Samuel Huntington, para quem a imigração de latinos enfraqueceria os valores norte-americanos, como o trabalho duro, a disciplina, a racionalidade e a responsabilidade. Subjacente a estes discursos, encontra-se uma outra característica comumente atribuída aos latinos: o fatalismo. Como o latino-americano seria "naturalmente" fatalista, entendendo a sua realidade como imutável, ele teria consequentemente poucos incentivos para dedicar-se ao trabalho com disciplina e racionalidade. Também estaria desprovido da capacidade de planejamento; não veria o futuro como uma possibilidade de progresso em relação ao presente, mas como mera continuidade.

O fatalismo também pode ser associado a uma concepção de tempo não linear. Afinal, se o futuro será igual ao presente (presenteísmo), não existe a possibilidade de progresso em direção a um mundo melhor. A única coisa que se pode esperar é repetição do mesmo, dentro de uma concepção temporal circular. Retoma-se aqui o famoso tema da literatura latino-americana sobre a repetição da estagnação latino-americana. É a temporalidade de Cem anos de solidão, de Gabriel García Marques: repetitiva e circular.

Na verdade, a associação entre a América Latina e uma temporalidade circular está em sintonia com uma narrativa eurocêntrica que, desde Hegel, reserva à América Latina um lugar fora da história. De acordo com o discurso eurocêntrico, quando se tenta trazer a América Latina para a modernidade, isto é, para uma trajetória linear de progresso, encontramos resistências que só podem ser explicadas por um atavismo de repetição. A América Latina ainda estaria ligada à Natureza (e à repetição a ela inerente), enquanto a Europa se movimentaria numa sequência histórica.

Alguns estudos empíricos realizados no século XX tentaram demonstrar esse traço de caráter latino-americano. Rogelio Diaz-Guerrero (1993) chegou a afirmar que, ao contrário dos anglo-saxões, os mexicanos tendem a reforçar pa- 
drões de adaptação a um caráter passivo e conformista. Os mexicanos seriam passivos e obedientes. Outro estudo, de José Miguel Salazar, aponta que os venezuelanos costumam se referir a si mesmos como preguiçosos, passivos, irresponsáveis, pessimistas e sem sentido histórico (apud Martin-Baró, 1996). Tais formulações aparecerão também como explicação para o subdesenvolvimento latinoamericano em relatórios do Centro para o Desenvolvimento Econômico e Social da América Latina (DESAL).

A abordagem da DESAL é bem representada pelas teorias de Fernando Duran. Martin-Baró cita Duran como exemplo de autor que associa a população latino-americana a traços de caráter como "confiança num líder autoritário", "indivíduo inserido num microcosmo de relações sociais", "conformismo" e "presenteísmo". Estas características dariam origem a cinco tipos de caráter social latinoamericanos: a) o capitalista de mentalidade moderna; b) o provinciano ligado a tradições e rituais; c) o camponês resignado; d) o caribenho irracional e irresponsável; e e) a índia isolada, passiva, fatalista, inclinada à magia. Na teoria de Duran, os cinco tipos coexistiriam em todas as nações latino-americanas.

A classificação de Duran restringe-se aos latino-americanos, mas, em sua estrutura e formato, lembra as classificações do século XVIII que vimos no capítulo 4. Lineu classificou o homo sapiens em variedades, associando cada tipo a um traço de caráter específico. Os europeus seriam engenhosos e os americanos (do norte e do sul), coléricos e amantes da liberdade. A teoria de Duran e de outros autores latino-americanos que tentaram detectar o fatalismo na região são exemplos de "colonialidade do saber", ou seja, de reprodução na América Latina de esquemas classificatórios e orientações epistemológicas surgidas na Europa e utilizadas ao longo dos séculos para criar uma oposição hierárquica entre europeus e não-europeus. Em suma, Duran absorve o discurso eurocêntrico sobre o fatalismo latino-americano e se dedica a pesquisar suas variantes.

Este tipo de análise foi criticado por Martín-Baró (1998), que rejeitou o fatalismo como um traço de caráter do latino-americano. Afirmar que o fatalismo faz parte da psique latino-americana seria tentar criar uma identidade fixa e fundamentalista para os latinos. Ao contrário, Martín-Baró mostra que o fatalismo é um esquema ideológico que se origina nas estruturas sociopolíticas e, posteriormente, acaba por se enraizar psiquicamente nas populações exploradas. Em outras palavras, o psiquismo fatalista seria produto de estruturas sociopolíticas e econô- 
micas que mantêm a América Latina como periferia do sistema financeiro internacional.

A reprodução destes discursos sobre o fatalismo não se dá apenas nos Estados Unidos, mas se estende a discursos contemporâneos na Europa. Como já discutido em outro capítulo desta tese, pode-se dizer que a lógica de equivalência prevalece na relação entre Estados Unidos e União Europeia, configurando o que Lynn Doty chamou de uma "Ligação Ocidental" (Western Bond). Neste momento, possíveis semelhanças entre europeus e latino-americanos são suspensas. Os valores em comum e os laços históricos, que tanto aparecem nas declarações de cúpula, são deslocados do eixo União Europeia-América Latina (o eixo da associação estratégica) para o eixo Estados Unidos-União Europeia (o eixo do Western Bond).

Em estudo realizado por Enescoa et al. , em 1995, constatou-se que as crianças espanholas tendiam a reproduzir determinados estereótipos sobre latinoamericanos. Estes foram retratados como pobres, traficantes de drogas, preguiçosos e bêbados. Ou seja, espanhois se referem aos latinos com termos e adjetivos similares aos outrora empregados pelos norte-americanos para se referir aos imigrantes mexicanos, aos pachucos. Estabelece-se assim uma cadeia de significantes em que o termo "migrante latino-americano" é associado a preguiçoso, indisciplinado, amante das festas e latin lover. Ele seria pouco racional, porém afetuoso, desinibido e musical. O discurso do eixo "Western Bond" sobre a migração latino-americana acaba por afirmar o que pretendia negar. $\mathrm{O}$ migrante se torna um parasita por fazer um cálculo racional sobre custos e benefícios, mas, ao mesmo tempo, este migrante não pode ser tão racional quanto o europeu e o norteamericano. A sua diferença está na sua irracionalidade, no seu envolvimento afetivo, na sua barbárie.

No entanto, temos de lembrar que existe uma discriminação entre o migrante legal e o ilegal nos documentos das cúpulas UE-ALC. O migrante latinoamericano que apresenta semelhanças com o europeu civilizado é aquele que pode se adaptar à Europa, aprender com os europeus e legalizar-se. Teríamos aqui uma situação semelhante à apontada por Escobar nos estudos sobre desenvolvimento. A "subjetividade subdesenvolvida" do latino-americano poderia ser melhorada com a ajuda dos europeus. Portanto, a capacidade de aprendizado do latinoamericano não estaria comprometida. 
Ao contrário, o migrante latino-americano que não apresenta raízes latinas estaria fadado a permanecer como um "outro bárbaro", um Caliban incapaz de falar a língua da sociedade receptora. Para este tipo de migrante, não haveria possibilidade de adaptação ou aprendizado.

Nos exemplos acima, podemos verificar o que Todorov chamou de duplo movimento em relação à diferença. Ou assimilamos o diferente, tornando-o um semelhante, ou inferiorizamos o diferente, transformando-o num bárbaro.

Retomando o nosso argumento, o discurso sobre uma associação estratégica baseada numa parceria entre iguais não se sustenta quando constatamos que, no tema migratório, permanece uma oposição hierárquica entre europeus e latinoamericanos. Estes não são poupados dos controles migratórios por fazerem parte de uma associação estratégica com a Europa.

\section{3 \\ O Fluxo Migratório entre Europa e América Latina-Caribe}

De meados do século XIX até o início do século XX, a América Latina foi considerada "uma 'terra de oportunidades', principalmente por emigrantes europeus" (Solimano, 2010, p. 117). Esta é a narrativa tradicional encontrada 'em grande parte dos textos que tratam das migrações entre a União Europeia e a América Latina. O recorte temporal de Solimano não está incorreto, mas nos parece modesto. Basta lembrar o projeto de Dom Manuel de transformar o Brasil num "imenso Portugal" (Cabral de Mello, 2002) que acolheria o excedente populacional do Reino. O Brasil, assim como toda a América Latina, seria uma "terra de oportunidades" desde a época do "descobrimento". A exaltação da natureza, das possíveis riquezas e do suposto "espaço vazio" eram temas constantes na literatura de viagens. Por outro lado, esta mesma literatura de viagens apontava o habitante dessas "terras de oportunidade" como um ser ainda em estado de natureza, um canibal, bárbaro e não-cristão. A terra seria “de oportunidades" para os de fora, os europeus empreendedores, mas não para o canibal ou bárbaro que não saberia o que fazer com tanta terra... 
Portanto, o fluxo migratório entre Europa e América Latina-Caribe não é um fenômeno que se estabelece em meados do século XIX, como apontam Solimano e outros. Este fluxo migratório faz parte da própria formação e da identidade destas duas regiões. Em outras palavras, é a relação, expressa pelo fluxo migratório, que constitui as entidades Europa e América Latina-Caribe. Ao se referir ao Brasil como um “imenso Portugal”, Dom Manuel estava criando uma identidade para o Brasil como um espaço semelhante a Portugal, uma extensão de Portugal ou, ainda, um Portugal ampliado. Aqui, portanto, o Brasil é o "mesmo" que Portugal.

Começa a se estabelecer, portanto, no século XVI a interpretação sobre o Brasil como um "outro Portugal" e da América do Sul como "outro Ocidente" (Merquior) ou um "extremo ocidente" (Rouquié). A América passa a ser uma extensão da Europa porque passa por um processo de assimilação cultural que a torna semelhante à Europa. Em suma, o "outro Portugal” e o "outro Ocidente" são uma cópia da Europa.

Como vimos com os autores pós-colonialistas no capítulo 3, Europa e América foram constituídas mutuamente como as primeiras identidades geoculturais do mundo moderno que se formava no século XVI. A esta formulação, acrescentaríamos que essa constituição mútua tem na migração o seu elemento central.

Os europeus migram para a América, trazendo seus costumes, mas o índio americano também marca sua presença em Paris. Em 1562, conforme relata Montaigne, o rei Carlos IX recebeu, em Rouen, três índios tupinambás que causaram alvoroço na Corte. Como apontado por Nocentelli-Truet (ver capítulo 4), os tupinambás, conhecidos por seu canibalismo, apareciam no debate entre católicos e protestantes como um "outro interno". Católicos e protestantes acusavam-se mutuamente de práticas canibais. É a partir do ensaio de Montaigne que o índio tupinambá canibal se transformará no "outro externo" em contraste com o qual o europeu estava começando a constituir a sua identidade. Em suma, o tupinambá participa da formação da identidade do europeu, seja quando este se coloca contra outros internos, seja quando se opõe a outros externos.

A formação do sujeito europeu como autônomo, racional e capaz de um conhecimento preciso sobre o mundo decorre não tanto do encontro com os americanos, mas da forma como esse encontro foi representado nos discursos europeus do período. O europeu surgia como o polo superior da oposição hierárquica 
europeu-americano ou europeu-canibal/tupinambá. A racionalidade do sujeito europeu opõe-se ao irracionalismo daqueles que comem carne humana.

Essa dicotomia constituirá o modelo por meio do qual a Europa lidará com outras alteridades. Segundo Quijano, é a partir da conexão do circuito Atlântico que os árabes se transformam no outro da Europa. Para Dussel, a invasão da América permite que a Europa adquira uma vantagem comparativa em relação a vizinhos do Oriente. A oposição hieráquica entre europeu e americano/canibal sofrerá um deslocamento no momento em que o europeu se relacionar com africanos, árabes ou asiáticos. Estes também ocuparão a posição inferior da oposição hierárquica e, se não são propriamente chamados de canibais, incorporam por outro lado aquelas características comumente associadas aos canibais. Eles serão os atrasados, preguiçosos, irracionais, pouco disciplinados.

Nos séculos XX e XXI, estes traços de caráter serão utilizados para se referir aos migrantes ou outros excluídos de forma geral. No entanto, é o migrante latino-americano que apresenta em sua genealogia a marca mais evidente do canibal americano do século XVI. Quando o europeu se refere ao migrante latinoamericano na contemporaneidade, ele retoma, de certa forma, a oposição hierárquica europeu/canibal do século XVI, agora atualizada como europeu/migrante latino-americano.

Por mais que os discursos das cúpulas UE-América Latina-Caribe exaltem o fluxo migratório baseado em valores comuns, o migrante latino-americano é representado pelas políticas migratórias europeias como um "outro bárbaro". $\mathrm{Pa}$ radoxalmente, é esta condição de "bárbaro" que permite ao migrante latinoamericano questionar o discurso sobre a associação estratégica como comunidade imaginada entre parceiros iguais.

\subsection{1}

\section{Os padrões migratórios e as inversões de fluxo}

Ao tratarmos das migrações entre Europa e América Latina-Caribe, não podemos deixar de considerar o papel da Ibéria. Como disse Buarque de Holanda, Portugal e Espanha funcionam como territórios-ponte entre a Europa e a América Latina e o Caribe. 
Na era dos "descobrimentos" e nos séculos XVII e XVIII, a migração de europeus para a América Latina e o Caribe provinha, sobretudo, da península Ibérica, mas também incluía franceses, holandeses e ingleses. Esse processo intensificou-se no final do século XIX e início do XX, com a migração em massa de europeus para a América do Norte e do Sul. De acordo com a International Organization for Migration (IOM), essa tendência foi estancada a partir das décadas de 1950 e 1960, quando a Europa viveu seus "Anos Dourados" de crescimento econômico e construção do Welfare State. A partir dos anos 80, o fluxo migratório se inverteu, ou seja, os latino americanos começaram a emigrar para a Europa, sobretudo para países do Sul do continente, como Itália, Portugal e Espanha. Com a entrada desses últimos dois países na Comunidade Econômica Europeia em 1985, as perspectivas de investimentos europeus, crescimento e geração de emprego aumentaram, atraindo um fluxo de latino-americanos que procurava fugir da estagnação da América Latina, às voltas com a crise da dívida dos anos 80. Segundo relatório de 2004 da OIM, o número de imigrantes latino-americanos em países como Espanha e Itália tem aumentado de forma dramática. Entre 1995 e 2003, “a população latino-americana na Espanha aumentou de 92.642 para 514.485” (OIM, 2004,p.7).

Alguns fatores teriam influenciado este fluxo recente, como as crises econômicas da América Latina (anos 90 e início do século XXI) e o maior controle migratório nos Estados Unidos após o 11 de setembro de 2001. Ainda de acordo com a OIM, os migrantes latino-americanos na Europa são formados por uma população jovem que se caracteriza por participar do mercado de trabalho e remeter grande quantidade de recursos para seus países de origem. Em 2004, os dados mostravam que US\$ 1 bilhão era remetido anualmente da Espanha e US\$ 1 bilhão de outras partes da Europa. De forma geral, "as afinidades culturais e linguísticas entre a UE e os países latino-americanos parecem facilitar a integração dos migrantes latino-americanos" (Idem).

A migração legal de latino-americanos para o sul da Europa foi favorecida por políticas que permitiam a dupla cidadania e a cidadania baseada na ancestralidade (jus sanguinis). No entanto, estas facilidades não contemplam todos os migrantes. Aqueles que não têm vínculos sanguíneos com portugueses, espanhois ou italianos não são beneficiados por estas políticas e encontram as mesmas restrições para entrar na UE que migrantes de outras regiões. 
Aqui já começa a se delinear uma distinção entre o migrante legal latinoamericano e o migrante ilegal latino-americano. O primeiro aparece nos discursos como um semelhante com direito a entrar na União Europeia; os laços de parentesco com europeus garantiriam essa semelhança. Ao contrário, o segundo é representado com um "outro" bárbaro, destituído da habilidade linguística necessária para sua adaptação ao país de destino. Na cadeia de significantes então mobilizada para se referir ao migrante ilegal latino-americano, reaparecem termos como preguiçoso, pouco instruído, parasita e indisciplinado.

O critério do jus sanguinis funciona como uma máquina de diferenciação entre tipos de migrantes. Aquele que apresenta algum grau de parentesco com o europeu seria legal e aquele sem qualquer parentesco europeu seria classificado como ilegal. Retoma-se, portanto, a distinção entre europeu/latino-americano, agora atualizada na oposição hierárquica latino-americano com raízes europeias e latino-americano sem raízes europeias. O latino-americano com raízes europeias poderia se adaptar e aprender com os europeus, enquanto o latino-americano sem aquelas raízes permaneceria como um "bárbaro".

Os números sobre a migração de latino-americanos para a Europa estão disponíveis em bases de dados como o Eurostat (Agência de Estatísticas Europeia) e a OCDE (Organização para a Cooperação e o Desenvolvimento Econômico). Embora essas instituições façam levantamentos estatísticos no âmbito de cada Estado nacional, não é possível comparar os dados fornecidos por cada uma delas devido à diferença de fontes e de conceitos.

No entanto, em análise de 2007, Beatriz Padilla e João Peixoto mostram que as migrações de latino-americanos para a Europa tem como destino mais comum os países do Sul da Europa. Na tabela abaixo, podemos ver que a Espanha é o país que recebe o maior número de migrantes latino-americanos, seguido pela Itália. A migração de latino-americanos para Portugal é bem inferior à da Espanha. Há mais migrantes latino-americanos no Reino Unido e na Alemanha do que em Portugal.

Abaixo apresentamos a tabela da análise realizada por Padilla e Peixoto em 2007:

Table 1. Latin American and Caribbean Foreign Population in Selected Eu- 


\begin{tabular}{|c|c|c|c|c|c|c|}
\hline \multicolumn{7}{|c|}{ ropean Countries, 2005* } \\
\hline \multirow[b]{2}{*}{ Countries } & \multicolumn{4}{|c|}{ Latin America and the Caribbean } & \multirow[b]{2}{*}{$\begin{array}{l}\text { Other na- } \\
\text { tionalities }\end{array}$} & \multirow[b]{2}{*}{ Total } \\
\hline & $\begin{array}{l}\text { South } \\
\text { Ameri- } \\
\text { ca }\end{array}$ & $\begin{array}{l}\text { Central } \\
\text { Ameri- } \\
\text { ca } \\
\text { and } \\
\text { Mexico }\end{array}$ & $\begin{array}{l}\text { Caribbe- } \\
\text { an }\end{array}$ & Total & & \\
\hline & \multicolumn{6}{|l|}{ Number } \\
\hline Austria & 4,174 & 759 & 1,909 & 6,842 & 758,461 & 765,303 \\
\hline Belgium (b) & 7,972 & 1,102 & 1,499 & 10,573 & 837,823 & 848,396 \\
\hline Denmark & 3,095 & 613 & 452 & 4,160 & 253,192 & 257,352 \\
\hline Finland & 971 & 277 & 221 & 1,469 & 106,877 & 108,346 \\
\hline France (d) & 25,357 & 3,950 & 17,355 & 46,662 & $3,216,524$ & $\begin{array}{l}3,263,18 \\
6\end{array}$ \\
\hline Germany & 66,459 & 10,270 & 17,031 & 93,760 & $6,107,491$ & $\begin{array}{l}6,201,25 \\
1\end{array}$ \\
\hline Greece (a) & 494 & 75 & 217 & 786 & 585,258 & 586,044 \\
\hline Italy (e) & 167,197 & 11,599 & 26,030 & 204,826 & $2,022,741$ & $\begin{array}{l}2,227,56 \\
7\end{array}$ \\
\hline $\begin{array}{l}\text { Luxem- } \\
\text { bourg (c) }\end{array}$ & 601 & 45 & 187 & 833 & 161,452 & 162,285 \\
\hline Netherlands & 19,714 & 1,638 & 2,280 & 23,632 & 675,719 & 699,351 \\
\hline Norway & 4,450 & 535 & 721 & 5,706 & 207,597 & 213,303 \\
\hline Portugal (f) & 55,366 & 386 & 690 & 56,442 & 312,855 & 369,297 \\
\hline Spain (g) & 946,116 & 20,461 & 98,339 & $\begin{array}{l}1,064,91 \\
6\end{array}$ & $1,956,892$ & $\begin{array}{l}3,021,80 \\
8\end{array}$ \\
\hline Sweden & 15,778 & 1,815 & 1,388 & 18,981 & 462,160 & 481,141 \\
\hline Switzerland & 28,239 & 2,792 & 7,948 & 38,979 & $1,485,684$ & $\begin{array}{l}1,524,66 \\
3\end{array}$ \\
\hline \multirow[t]{2}{*}{$\begin{array}{l}\text { United } \\
\text { Kingdom } \\
\text { (a) }\end{array}$} & 42,204 & 5,147 & 65,430 & 112,781 & $2,628,607$ & $\begin{array}{l}2,741,38 \\
8\end{array}$ \\
\hline & \multicolumn{6}{|l|}{ Percent } \\
\hline Austria & 0.5 & 0.1 & 0.2 & 0.9 & 99.1 & 100 \\
\hline Belgium (b) & 0.9 & 0.1 & 0.2 & 1.2 & 98.8 & 100 \\
\hline Denmark & 1.2 & 0.2 & 0.2 & 1.6 & 98.4 & 100 \\
\hline Finland & 0.9 & 0.3 & 0.2 & 1.4 & 98.6 & 100 \\
\hline
\end{tabular}




\begin{tabular}{|c|c|c|c|c|c|c|}
\hline France (d) & 0.8 & 0.1 & 0.5 & 1.4 & 98.6 & 100 \\
\hline Germany & 1.1 & 0.2 & 0.3 & 1.5 & 98.5 & 100 \\
\hline Greece (a) & 0.1 & 0.0 & 0.0 & 0.1 & 99.9 & 100 \\
\hline Italy (e) & 7.5 & 0.5 & 1.2 & 9.2 & 90.8 & 100 \\
\hline $\begin{array}{l}\text { Luxem- } \\
\text { bourg (c) }\end{array}$ & 0.4 & 0.0 & 0.1 & 0.5 & 99.5 & 100 \\
\hline Netherlands & 2.8 & 0.2 & 0.3 & 3.4 & 96.6 & 100 \\
\hline Norway & 2.1 & 0.3 & 0.3 & 2.7 & 97.3 & 100 \\
\hline Portugal (f) & 15.0 & 0.1 & 0.2 & 15.3 & 84.7 & 100 \\
\hline Spain (g) & 31.3 & 0.7 & 3.3 & 35.2 & 64.8 & 100 \\
\hline Sweden & 3.3 & 0.4 & 0.3 & 3.9 & 96.1 & 100 \\
\hline Switzerland & 1.9 & 0.2 & 0.5 & 2.6 & 97.4 & 100 \\
\hline $\begin{array}{l}\text { United } \\
\text { Kingdom } \\
\text { (a) }\end{array}$ & 1.5 & 0.2 & 2.4 & 4.1 & 95.9 & 100 \\
\hline
\end{tabular}

Notes: *Most data correspond to January 1, 2005, except when indicated:
(a) January 1, 2004.
(b) January 1, 2003.
(c) January 1, 2001.
(d) March 8, 1999.
(e) Residence permits/permits of stay as of January 1, 2004.
(f) Residence permits and permits of stay as of December 31, 2005.
(g) Residence permits as of December 31, 2006. The Caribbean includes Cuba, Dominican Republic, and "other countries" in Latin America.
Source: Authors' calculations based on Council of Europe, 2004 and 2005, ex- cept Italy (Istat and Ministero dell'Interno, Italy), Portugal (INE and SEF, Portu- gal), and Spain (INE and Ministerio de Trabajo y Asuntos Sociales, Spain).

Tabela 1: População Estrangeira latino-americana e caribenha em países europeus selecionados (2005).

O relatório mais recente sobre fluxos migratórios foi publicado pela OCDE em 27 de junho de 2012 e mostra que migrantes da América Latina e do Caribe na Europa têm taxas de desemprego de desemprego de $22 \%$, contra $25 \%$ dos imigrantes do Norte da África. "Não há surpresa dado que esses grupos de migrantes estão sobrerepresentados em setores (construção) e países (Espanha, Itália, Grécia) fortemente afetados pela crise econômica" (OCDE, 2012, p.69).

Desde 2008, com o início da crise financeira na Europa, o fluxo migratório entre União Europeia e América Latina tem dado sinais de inversão. Principalmente Espanha e Portugal começam a registrar aumento no número de imigrantes 
para a América Latina. Segundo Roderick Parkes, analista do Instituto Alemão de Relações Internacionais e de Segurança, "os europeus nunca pensaram que poderiam ter uma fuga de cérebros, sempre se preocuparam mais com a imigração" (Parkes, 2012, p.1).

Thomas Liebig, especialista em migração da Organização para a Cooperação e o Desenvolvimento Econômico (OCDE), declarou que os levantamentos da organização já apontam para uma diminuição da imigração e aumento da emigração no continente. Em 2011, a Espanha registrou pela primeira vez em dez anos uma migração líquida negativa de 50 mil cidadãos (LIEBIG, 2012, p.1).

No entanto, o relatório da OCDE de 2012 mostra que, até o momento, o aumento da emigração nos países afetados pela crise do euro (Grécia, Irlanda, Itália, Portugal e Espanha) tem sido menor do que o esperado. Em relação à emigração europeia provocada pela crise do euro, os dados e as conclusões ainda parecem muito prematuros.

\section{4}

\section{A Diretiva do Retorno e a associação estratégica}

A Política Comum de Asilo europeia foi criada em outubro de 1999, ou seja, quatro meses depois da primeira reunião de cúpula entre União Europeia e América Latina, realizada em junho de 1999, no Rio. Em sua primeira versão, a política de asilo proclamou o seu vínculo com a Convenção para os Refugiados de 1957 e com o respeito aos direitos humanos. Apesar disso, ela vem apresentando um caráter anti-imigração desde sua gestação.

Os acontecimentos do 11 de setembro apenas exacerbaram uma tendência de securitização que já vinha se manifestando na União Europeia nos anos anteriores. A culminância desse processo de securitização ocorreu com a aprovação da Diretiva do Retorno em 18 de junho de 2008, considerada uma das legislações migratórias mais restritivas do mundo. Como já comentado, a Diretiva foi aprovada no mesmo ano da Declaração de Lima entre União Europeia e América Latina e Caribe.

Também chamada de "Diretiva da Vergonha" por organizações de Direitos Humanos, a lei permite prender imigrantes ilegais por até 18 meses antes de serem expulsos ou repatriados para seus países de origem. Durante a detenção, os imi- 
grantes podem ter acesso à assessoria jurídica gratuita. Além disso, ficam proibidos de entrarem na União Europeia por cinco anos. Em outro artigo, a diretiva prevê a detenção de menores desacompanhados (num caso inédito de prisão de crianças) e sua expulsão.

Se confrontarmos as Declarações de Cúpula entre a União Europeia e a América Latina e o Caribe e a Diretiva do Retorno, perceberemos que os discursos de ambas são antagônicos. As declarações que fundam a associação estratégica garantem um espaço birregional comum para europeus e latino-americanos. No entanto, a Diretiva do Retorno, por não poupar migrantes latino-americanos e caribenhos, acaba invalidando o discurso das cúpulas sobre uma comunidade imaginada formada por europeus e latino-americanos-caribenhos. Em outras palavras, a Diretiva do Retorno não faz distinção entre migrantes latino-americanos, provenientes da associação estratégica, e migrantes não-latino-americanos. A associação estratégica não provê nenhuma proteção aos migrantes latino-americanos diante da Diretiva do Retorno. Ela não é capaz de blindá-los em relação à Diretiva.

O "nós" monofônico criado pelo discurso da associação estratégica é rompido pela Diretiva do Retorno. Em vez do monologismo criado pelo "nós" da associação estratégica, temos uma explicitação da polifonia. De um lado, a União Europeia defende a Diretiva; de outro, a América Latina e o Caribe a condenam.

Ao adotar a Diretiva, a União Europeia compromete sua própria imagem como promotora dos direitos humanos. Como discutido no primeiro capítulo da tese, a União Europeia tenta projetar-se no cenário internacional como defensora dos direitos humanos. Urfan Khaliq destaca que a UE preocupa-se em apresentar uma dimensão ética em sua política externa. O Alto Representante da UE para a Política Externa e de Segurança Comum, Javier Solana, declarou que:

Nossa União está preparada para desempenhar um papel internacional proeminente no próximo século. Os direitos humanos permanecerão no coração deste papel porque os direitos humanos estão no centro da integração europeia. Temos uma União de valores" (Solana apud Khaliq, 2008, p.8).

Haveria, portanto, uma contradição entre os objetivos de política externa da União Europeia (difusora de direitos humanos) e a adoção da "Diretiva do Retorno" (2008). Nesse sentido, podemos dizer que houve uma aproximação entre a União Europeia e os Estados Unidos em termos de política migratória, reforçando 
a tese do "Western Bond" (ligação ocidental). Ao securitizarem a migração, Estados Unidos e União Europeia mantêm-se unidos em torno dos mesmos valores, reforçando a "comunidade atlântica" (ver capítulo 2).

Consequentemente, há um enfraquecimento da associação estratégica com a América Latina e o Caribe. De fato, a diretiva do retorno provocou protestos de vários governos da América Latina/Caribe. O secretário-geral Ibero-americano, Enrique Iglesias, afirmou que a nova lei contraria a tendência de encontrar soluções equitativas, tanto para países emissores quanto para receptores, em relação ao tema. "As novas medidas poderão produzir grandes injustiças. Elas acabam com o clima de confiança, de harmonia e de respeito que é indispensável para uma cooperação internacional efetiva e justa em matéria de política migratória" (Iglesias, 2008, p.1).

A diretiva também foi criticada por presidentes de diversos países latinoamericanos, como Luiz Inácio Lula da Silva, Hugo Chávez, Rafael Correa e Evo Morales. Os últimos três ameaçaram retaliar com medidas como a suspensão do envio de petróleo para a Europa e uma lei de retorno de capitais. Para alguns países da América Latina e do Caribe, a diretiva pode representar perda de recursos fundamentais para o desenvolvimento. As remessas de lucros são responsáveis por $10 \%$ do PIB da Bolívia e por 7,1\% do do Equador.

O presidente boliviano, Evo Morales, apresentou à União Europeia uma carta de protesto contra a Diretiva do Retorno no dia 10 de junho, ou seja, oito dias antes de sua aprovação pelo Parlamento. No texto, ele exortava a União Europeia a refletir sobre a política migratória prestes a ser adotada:

Até o fim da Segunda Guerra Mundial, a Europa foi um continente de emigrantes. Milhões de europeus vieram para as Américas para colonizar, escapar da fome, da crise financeira, das guerras, dos totalitarismos europeus e da perseguição de minorias étnicas. (...) Os europeus entraram nos países latino-americanos e na América do Norte sem vistos ou condições impostas por autoridades. Eles foram bem-vindos e continuam a sê-lo em nosso continente, que absorveu naquela época a crise política e a miséria europeia. Vieram para o nosso continente para explorar recursos naturais e transferi-los para a Europa. (Morales, 2008, p.1)

Morales retoma um discurso que aparece na cúpula de Lima. Naquele documento, proclamava-se o impacto positivo dos fluxos de migração em ambas as direções. É como se ele tivesse de lembrar o Parlamento europeu sobre o que foi 
acordado em Lima. Mas, ao contrário da Declaração de 2008 - que tenta produzir um consenso, uma unidade entre UE e América Latina no tema migratório, silenciando sobre a colonização -, o discurso de Morales reintroduz a exploração na narrativa histórica. Ou seja, critica-se a presença de uma única voz temporal na concepção de história e tenta-se criar uma memória a partir de um outro lugar de enunciação.

Na narrativa histórica tradicional, o discurso da chegada dos europeus à América os apresenta como viajantes dispostos a conhecer o Novo Mundo. Como mostrou Pratt (capítulo 4), os relatos de viagem eram uma forma de apresentar o lado benévolo da colonização. O migrante europeu é representado como turista, viajante, curioso, cientista, civilizado. O discurso dos "descobrimentos" e da colonização que se seguiu não trata de migrações. Este termo não faz parte da cadeia de significantes que instituirá um ponto nodal do discurso hegemônico sobre o “descobrimento". Ao contrário, o discurso hegemônico dos séculos XVI, XVII e XVIII apresentará as viagens ao Novo Mundo como um ato estimulado por um espírito de aventura, pela curiosidade e a vontade de construir algo novo.

Como vimos no capítulo 4, o discurso europeu deste período é preponderantemente monológico. Dizemos preponderantemente porque todo texto monológico traz, pelo menos, uma polifonia implícita. Aqui, o monologismo é representado pelo europeu, que justificará a conquista com base na oposição hierárquica entre a civilização e a Natureza do Novo Mundo. O sujeito europeu, autônomo, racional e civilizado deve levar a cristandade e a ordem humana para os bárbaros e canibais da América.

A construção do europeu como turista se assemelha a uma estratégia para encobrir o fato da colonização. O europeu vem à América como um turista, um cientista, um mero curioso por novos aprendizados, jamais como alguém interessado na exploração do outro. O relato de viagem é o texto de um europeu "turista" que decidiu contar suas experiências aos contemporâneos.

O discurso contra-hegemônico de Morales subverte esta narrativa, rompendo com os pontos nodais estabelecidos, como "europeu/turista/civilizado" e "latino-americano/migrante/ilegal", e invertendo a dicotomia. O europeu veio para as Américas para "explorar recursos naturais e transferi-los para a Europa"(loc. cit). Esta caracterização aproxima o significante europeu do significante bárbaro. Como os bárbaros do Império Romano, os europeus teriam invadido o sul e pilha- 
do nossas riquezas. Em contraste, a migração de latino-americanos e caribenhos para a União Europeia no século XXI é interpretada como uma contribuição dos latinos à prosperidade da Europa. "O migrante oferece uma solução para os problemas demográficos e financeiros da União Europeia" (loc. cit.).

Entretanto, o discurso de Morales realiza apenas o primeiro passo da desconstrução, pois se limita a inverter a dicotomia. Depreende-se de seu pronunciamento que os europeus são bárbaros gananciosos e egoístas enquanto os latinoamericanos são civilizados e solidários. Não temos aqui o deslocamento que constitui o segundo movimento da desconstrução. Se este fosse realizado, o significante bárbaro perderia o significado de atrasado, rude, sem educação e cultura.

A Diretiva do Retorno reforça a lógica do inside/outside para o espaço regional, criando a ideia de uma Fortaleza Europa. Obviamente, esta reafirmação das fronteiras da UE não afeta apenas imigrantes latino-americanos. O processo de securitização e a associação da migração com o crime e o terrorismo também produz efeitos sobre os fluxos de imigrantes africanos, árabes e mesmo asiáticos. Porém, aqui retormamos nosso ponto sobre a especificidade do "outro latinoamericano", em contraste com os possíveis outros orientais e africanos. Enquanto estes representam no imaginário europeu um "outro absoluto", completamente distante dos valores europeus, o "outro latino-americano" não é um "outro absoluto". Ele participa de uma prática discursiva na qual sua posição oscila entre ser "o mesmo do europeu", uma "extensão do europeu” e ser "o outro bárbaro, canibal, pouco civilizado".

Por este motivo, embora a Diretiva de Retorno atinja igualmente todos os migrantes ilegais, independentemente de sua origem, seu impacto sobre a migração ilegal latino-americana coloca em evidência a fragilidade da associação estratégica. O discurso das cúpulas entre União Europeia e América Latina sobre laços históricos entre as duas regiões não resiste ao confronto com uma Diretiva do Retorno que não faz concessões a migrantes latino-americanos por conta de sua semelhança com os europeus.

Um outro ponto a ser destacado diz respeito ao choque entre a "proposta" de fronteira da associação estratégica e a "proposta" de fronteira da Diretiva do Retorno. A associação estratégica propõe a criação de um espaço birregional sustentado pelos mesmos valores, ou seja, a fronteira UE-América Latina-Caribe tenderia a ser relativizada. O inside é representado por toda a área da associação 
estratégica. No entanto, esta fronteira é restabelecida pela Diretiva do Retorno, que reforça a separação entre o espaço europeu (inside) e o mundo exterior (outside).

Ao ser localizado no outside, o migrante latino-americano é alvo das mesmas técnicas de securitização destinadas a outros migrantes. Um exemplo de transformação do latino-americano em "outro bárbaro" pode ser encontrado na área de espera do aeroporto de Barajas, em Madri. Os brasileiros são colocados numa zona de espera antes de serem deportados. Segundo relatos de brasileiros detidos em Barajas, os policiais impediram os passageiros de tomarem banho e mudar de roupa. Muitos também não sabiam falar espanhol e, por isso, tinham mais dificuldades para apresentarem suas solicitações. Estas descrições nos remetem às oposições hierárquicas entre civilizado/bárbaro, europeu/canibal ou europeu/latino-americano. O migrante ilegal latino-americano é tratado como um bárbaro que não consegue falar corretamente a língua local e que pode passar uma semana sem tomar banho e trocar de roupa.

Ao enfatizarem sua diferença em relação ao latino-americano, as autoridades espanholas acabam por minar o próprio discurso do governo espanhol sobre o iberoamericanismo. Durante as comemorações sobre o Bicentenário da Independência da América Espanhola, a afirmação de uma latinidade a ligar Europa e América Latina e Caribe serviu para reforçar a versão espanhola sobre os benefícios da colonização do continente. Se o "outro" foi transformado num semelhante pelo processo de colonização, então por que este semelhante não poderia agora entrar em território espanhol?

Consequentemente, a associação estratégica também resulta enfraquecida pelas práticas realizadas no aeroporto de Barajas, uma vez que um de seus pilares era justamente a latinidade, agora entendida como algo inferior. Se, na associação estratégica, a latinidade era o que unia europeus e latino-americanos, nas práticas discursivas de construção do outro latino-americano, a latinidade será justamente o critério de diferenciação. O espanhol é antes de tudo um europeu, não um latino.

A Diretiva do Retorno também foi criticada por intelectuais europeus, como o sociólogo Sami Nair, que considerou a diretiva "um capítulo sombrio da nossa história" (2008, p.1). Destacou ainda que "a União Europeia trai seus princípios ao aprovar esta lei" (loc. cit) e que a nova legislação "não tem nada a ver com os valores autoproclamados da UE" (loc. cit). O discurso de Nair retoma um 
tropo comum na Europa contemporânea, como vimos no capítulo 1 desta tese: o do "velho e virtuoso continente". O estranhamento e o repúdio de Nair ocorre por conta de sua crença de que a União Europeia é essencialmente uma defensora dos direitos humanos e dos valores civilizados. A Diretiva do Retorno é algo que confronta o "discurso sobre a grandeza europeia" (Milovic, 2007, p. 47). Vale recordar que a cultura europeia foi descrita por Riemen (capítulo 2) como "essencialmente cosmopolita” (2004, p. 12). A crítica de Nair à Diretiva parte do mesmo pressuposto. A nova legislação migratória contraria os princípios da UE porque estes seriam essencialmente cosmopolitas.

Destituída de suas “virtudes”, a União Europeia não poderia mais apresentar o discurso sobre uma nova ordem internacional destinada a preservar os direitos humanos e tampouco considerar a América Latina e o Caribe como parceiros nesse projeto. $\mathrm{O}$ tratamento dado a migrantes ilegais latino-americanos invialibiza um discurso sobre direitos humanos na ordem internacional que contaria justamente com latino-americanos como parceiros (ver capítulo 2).

Mas seria a Diretiva do Retorno algo tão inédito na história europeia? Como mostrou Amartya Sen, os direitos políticos e civis fazem parte da cultura ocidental recente. Na história europeia, temos períodos de democracia e autoritarismo, de acolhimento e rejeição do outro, de liberdade e de repressão. Entendemos que o discurso sobre a "grandeza da Europa" só pode se constituir com base numa seletividade da memória que rechaça os períodos sombrios do continente e elege os luminosos como os verdadeiros representantes da tradição europeia.

Embora qualquer crítica à Diretiva do Retorno seja bem-vinda, notamos que o discurso de Nair parte do pressuposto de uma essência, de um fundamento europeu. Mas o fundamento, ainda que exista, é contingente e histórico, sujeito a uma modificação a partir do momento em que um grupo social não hegemônico contesta o ponto nodal estabelecido e tenta atribuir um outro significado ao significante vazio. A Europa não é, em seu Ser, fundamentalmente civilizada ou bárbara. Isto só é decidido contingencialmente na luta política.

Da mesma forma, a interpretação de Morales sobre o processo migratório entre a Europa e a América Latina seleciona determinados elementos do passado para construir uma narrativa favorável à América Latina e desfavorável aos europeus. Os europeus seriam vistos como essencialmente agressivos e exploradores do trabalho alheio, enquanto os latino-americanos são associados, contrariando 
uma longa tradição do discurso eurocêntrico, a pessoas trabalhadoras e bem intencionadas.

Tanto num caso como no outro, estamos diante de tentativas de essencializar o "ser europeu" e o "ser latino-americano". Características positivas ou negativas são atribuídas a um ou outro conforme os interesses de quem as enuncia.

A aprovação da Diretiva do Retorno mostra a fragilidade do discurso sobre a "civilização europeia" e sobre uma ordem mundial que poderia ser construída a partir do modelo europeu de respeito aos Direitos Humanos, à lei internacional e à solução pacífica de controvérsias. Com a nova lei, percebemos que os supostos "fundamentos" ou "princípios" da União Europeia não estão ligados a uma essência europeia, mas são apenas contingentes.

\section{5 .}

\section{Desconstruindo a oposição hierárquica migrante legal/migrante ile- gal latino-americano: a hospitalidade incondicional}

Nesta seção, pretendemos examinar como a oposição hierárquica entre migrante legal latino-americano e migrante ilegal latino-americano reproduz oposições hierárquicas que vimos no capítulo 4, como entre cristão e não-cristão, europeu e bárbaro, civilizado e bárbaro, razão e emoção. Veremos também como o conceito de hospitalidade incondicional, desenvolvido por Derrida em $\mathrm{Da} H o s p i$ talidade, pode ser utilizado para desconstruir essas oposições. É verdade que o texto de Derrida não se refere especificamente aos migrantes latino-americanos. No entanto, sua abordagem nos permite perceber as dicotomias envolvidas na questão da migração e nas classificações dos migrantes. Por isso, sua leitura sobre a migração nos servirá de base - ainda que não a única - para pensar a posição do migrante latino-americano na associação estratégica. A sensação de não estar de todo é permanente nestes migrantes, que se adaptam à sociedade receptora europeia por meio de um bilinguajamento (Mignolo, 2002).

Em Da Hospitalidade, Derrida se refere àqueles que estão em movimento perpétuo: imigrantes ilegais, deslocados, trabalhadores migrantes, refugiados, exilados... A pergunta que Derrida coloca neste texto é: como podemos lidar com esta realidade? Qual a concepção de hospitalidade que costumamos empregar com 
o estrangeiro? Para o autor, esta situação exige mais do que "uma mutação do espaço social e geopolítico, uma mutação política e jurídica, mas acima de tudo uma conversão ética" (1997, p. 131). Segundo Derrida, é a política de fronteiras contemporânea que faz emergir a questão do estrangeiro ao perguntar "quem é você?”, “qual o seu nome?”, “qual seu lugar de origem?”. Até então, aquele que chegava não se considerava como estrangeiro. É a pergunta feita na fronteira que instituirá a diferença.

No caso da migração de latino-americanos para a União Europeia, a pergunta seria feita na fronteira da Fortaleza Europa. Supostamente, a associação estratégica deveria suspender a pergunta sobre a origem, já que pressuporia uma origem comum latina. Estaríamos diante de uma situação em que a "semelhança de valores", exaltada como um dos pilares da comunidade imaginária União Europeia-América Latina-Caribe, evitaria a pergunta sobre a origem. A semelhança cultural entre europeus e latino-americanos estimularia, se não uma "conversão ética", pelo menos uma abordagem ética e uma maior tolerância no acolhimento do latino-americano na Europa. Por outro lado, como discutiremos mais à frente, pode-se argumentar que a semelhança cultural não equivale a uma conversão ética. Ser ético com o que é semelhante não coloca à prova nossa capacidade de ser ético.

Como vimos, a associação estratégica será cindida pela Diretiva do Retorno, que recoloca a pergunta sobre a origem. Sob as regras da Diretiva, o migrante latino-americano passa a ser submetido às mesmas perguntas destinadas a qualquer outro migrante. Aqui, o discurso sobre a semelhança de valores entre europeus e latino-americanos se esvai.

\section{5 .1}

\section{O estrangeiro, o bárbaro e o fantasma}

Para Derrida, o estrangeiro, por sua simples presença, questiona a suposta homogeneidade da sociedade de destino ao apontar as falhas do modo de vida e da lei local. Provoca, desta forma, uma desnaturalização daquilo que era tido como um dado, uma verdade absoluta. Mais do que isto: ele questiona a própria ordem internacional dividida em Estados soberanos que conferem cidadania aos que estão dentro e excluem os de fora. 
É justamente nesse questionamento do modo de vida local que o estrangeiro critica a noção de justiça como direito, ou seja, é justo o que está na lei. O estrangeiro questiona o fundamento da lei e o fundamento de uma determinada sociedade, revelando seu caráter histórico e contingente. Entre as leis locais, está a da hospitalidade condicional, tomada como um dado natural da realidade.

Derrida mostra ainda a distinção que se fazia entre o estrangeiro e o bárbaro/fantasma na pólis grega. No Sofista de Platão, o estrangeiro desafia a autoridade de Parmênides, questionando o seu discurso e a sua forma de falar. $\mathrm{O}$ estrangeiro fala uma língua estranha. Retoma-se aqui um tema que já tratamos em outras partes desta tese: a importância da língua na determinação do outro (ver capítulo 4). Apesar de não falar a língua local, o estrangeiro é recebido na polis grega, pois, considera-se que ele seja capaz de aprender o grego. Por já cidadão em outro local, ele está acostumado a obedecer a leis. Existiria assim um mínimo de entendimento entre o grego e o estrangeiro, o que permitiria a constituição de um pacto segundo o qual aquele que está fora da sua pólis tem de se apresentar quando chega à fronteira de uma outra pólis.

O oposto desta atitude caracterizaria o que hoje chamamos de migração ilegal. O pacto grego, portanto, visava a evitar uma "migração" não consentida ou uma migração ilegal. É interessante notar que o estrangeiro, embora continue sendo um "outro", merece o respeito dos gregos.

Diferente será o tratamento concedido ao bárbaro ou fantasma, com o qual não é possível relacionar-se. Como vimos no capítulo 4, o bárbaro não é capaz de usar a linguagem; só consegue grunhir, balbuciar. Portanto, não há qualquer possibilidade dele vir a aprender a língua grega e decodificar as regras da polis. Supõe-se ainda que o bárbaro não venha de uma polis com uma ordem jurídica estabelecida. Ele encontra-se num estado de natureza, anterior à instituição da lei e da ordem. O bárbaro ou fantasma encontra-se, assim, numa situação mais desvantajosa do que o estrangeiro ou o xenos. Enquanto estes são acolhidos como visitantes da pólis, o fantasma é visto como fora-da-lei e da ordem.

\section{5 .2}

\section{O migrante latino-americano na UE: estrangeiro ou bárbaro?}


$\mathrm{Na}$ associação estratégica, a oposição hierárquica entre o estrangeiro e o bárbaro/fantasma pode ser pensada em termos de migrante legal latino-americano e migrante ilegal latino-americano. Como vimos, na dicotomia estrangeiro/bárbaro, o primeiro termo é hieraquicamente superior ao segundo. Da mesma forma, o migrante legal latino-americano está numa posição mais vantajosa do que o migrante ilegal latino-americano. Assim como acontecia com o "estrangeiro" na pólis grega, o migrante legal latino-americano é bem recebido quando chega à União Europeia. Ele provém de uma outra "pólis" e, por isso, pode apresentar suas credenciais na fronteira europeia. Este tipo de migrante latino-americano aparecerá como um semelhante do europeu, seja por laços de consanguineidade seja por compartilhar uma cultura comum. O discurso da associação estratégica sobre uma semelhança de valores entre europeus e latino-americanos é aqui mobilizado para legitimar a migração de latino-americanos. O estrangeiro da pólis grega teria capacidade para aprender a língua e as leis do país receptor. Em relação ao migrante legal latino-americano, espera-se que este migrante já saiba a língua do país receptor - no caso de um migrante hispânico na Espanha - ou, pelo menos, tenha capacidade de aprendê-la.

Ao contrário, o migrante ilegal latino-americano é visto como um bárbaro ou fantasma pelas autoridades de fronteira da UE. Este tipo de migrante acaba atualizando vários dos adjetivos outrora usados para se referir ao "outro bárbaro latino-americano", como, por exemplo, preguiçoso e indisciplinado. Sua capacidade de aprender a língua do país receptor é considerada limitada pois ele carece da racionalidade e da disciplina para aprendê-la.

Se retomarmos os deslocamentos na cadeia de significantes, veremos que o lugar ocupado pelo bárbaro e pelo fantasma na pólis grega foi substituído no século XVI pelo neologismo canibal. O bárbaro passou a ser o canibal/antropófago incapaz de pronunciar palavras inteligíveis. O Caliban de Shakespeare (anagrama de canibal) só conseguia balbuciar. Existe, portanto, uma proximidade entre o bárbaro e o fantasma da pólis grega, descritos por Derrida, e o Calibán ou canibal do período do "descobrimento" da América. O canibal ocupará o lugar do bárbaro.

Em relação à linguagem, Calibán será um bárbaro, segundo a definição grega. Porém, essa não adequação de Calibán contém uma dimensão contestadora. 
Assim como o bárbaro e o fantasma, Calibán acusa as leis que o definem como não-humano. Em outras palavras, Calibán denuncia a opressão colonizadora. Sua presença, assim como a do migrante ilegal latino-americano no século XXI, incomoda porque revela o lado obscuro da modernidade, a colonialidade do poder e do saber. Calibán é mantido numa caverna, escondido, distante da luminosidade. A ele estão reservadas somente as trevas. Não há qualquer possibilidade de que ele venha a aprender a língua e a respeitar as leis do conquistador.

Ainda que o espanhol e o português sejam, ao mesmo tempo, a língua do migrante latino-americano e a língua oficial do país receptor, isto não elimina a discriminação. O espanhol e o português do "outro bárbaro latino-americano" são por vezes considerados degenerações da língua matriz, derivações ou cópias do modelo linguístico.

Como vimos no capítulo teórico (p. 127), Mignolo destaca o espaço fraturado do bilinguismo e do bilinguajamento. Existe uma geopolítica da língua. "Projetos globais traçam mapas linguísticos, cartografias literárias e epistemológicas" (Ibidem, 2003, p. 346) e, neste processo, impõem o que seria a língua adequada. O desvio do padrão linguístico monológico resulta numa "língua subalterna". Pode-se dizer que há também uma tentativa de "colonização do gênero discursivo" (Ibidem, 2003, p. 352), com a desconsideração de narrativas que não obedecem à gramática da língua mãe.

Para entendermos o hibridismo linguístico do migrante latino-americano, devemos relembrar as considerações de Mignolo sobre a posição do espanhol e do português na constituição da modernidade. $\mathrm{O}$ autor lembra que, em conferência sobre a história universal, Hegel apontou o alemão, o francês e o inglês como as línguas do coração da Europa. Nesta época, o português e o espanhol, como línguas de Impérios em decadência, estavam se tornando subalternas. Este teria sido o "primeiro rebaixamento da língua espanhola na construção da modernidade europeia" (Ibidem, 2003, p. 353). O segundo rebaixamento teria ocorrido quando, após a Segunda Guerra Mundial, o espanhol tornou-se uma das línguas do Terceiro Mundo. Deve-se notar que este segundo rebaixamento é, em parte, devido às variações do espanhol na América Latina, consideradas versões degradadas do espanhol metropolitano. O terceiro rebaixamento envolve transformações e hibridismos linguísticos ocorridos em comunidades de imigrantes mexicanos nos Estados Unidos. Para os puristas, o espanhol chicano era considerado uma língua er- 
rada criada por migrantes mexicanos que não falam nem o espanhol padrão nem o inglês padrão.

Oswald de Andrade também critica essa subserviência à língua do conquistador. No exemplo abaixo, a incorreção gramatical passa a ser uma forma de autoafirmação e resistência à colonização.

\section{Vício de Fala}

Para dizerem milho dizem mio

Para melhor dizem mio

Para pior pio

Para telha dizem teia

Para telhado dizem teiado

E vão fazendo telhados

(Andrade, 1974, p.89).

O poema de Oswald mostra um hibridismo na língua portuguesa. O título Vício de fala chama ironicamente a atenção para o desvio do padrão culto da norma como um defeito, um vício, algo degradante. $\mathrm{O}$ vício não deixa de ser também uma doença no corpo da língua mãe. A estratégica do escritor será a de mostrar como a deformação do português é uma criação válida para os que a falam. A não imitação do português da elite significa abertura para o dialogismo, em que registros diferentes aparecerão lado a lado. O enxerto realizado por Oswald tem um caráter crítico e, ao mesmo tempo, revela nossa identidade como oscilação entre dois registros, o culto e o inculto.

Este processo é também uma forma de descolonização do saber. Ao recorrer a enxertos e ao dialogismo, Oswald produz um texto entre-línguas (Khatibi) ou, pelo menos, entre dois registros. Em outras palavras, produz um pensamento liminar, a partir da fronteira. Instaura um lócus de enunciação a partir da América Latina.

Uma das formas de construção do latino-americano como um "outro bárbaro" passa, portanto, pela depreciação de sua língua. Recorrendo a Bakhtin, podemos dizer que essa construção se dá por meio de um sufocamento da polifonia 
do discurso pelo monologismo da língua padrão. Cria-se uma oposição hierárquica entre a língua matriz e as línguas derivadas ou dialetos, reafirmando a superioridade da primeira. De acordo com a narrativa monológica, as línguas derivadas e necessariamente degeneradas - são um suplemento da língua principal.

Até aqui, consideramos as variações dentro de uma mesma língua. Porém, o migrante ilegal latino-americano também pode ser aquele que fala quéchua ou que mistura o espanhol com sua língua americana nativa. Neste segundo exemplo, podemos ter um espanhol "gramaticalmente incorreto", que, segundo Bakhtin, representaria uma polifonia, com duas vozes separadas uma da outra pelo tempo ou por diferenciação social.

O desafio que este migrante ilegal coloca para o modo de vida local é ainda mais radical do que o do migrante legal. Ele pode provocar um incômodo por trazer uma diferença ou uma polifonia em relação à própria ideia de latinidade. Como discutido em outro capítulo, a latinidade faz parte de um discurso monológico que exclui outras tradições da América do Sul, como as indígenas e as africanas. Para os que esperavam um migrante latino-americano apenas com características latinas, pode ser desprazeroso constatar que ele traz consigo tradições ameríndias ou africanas.

A contestação à língua e ao modo de vida local ocorre muitas vezes por meio do bilinguajamento, um estar entre-lugares, num hibridismo entre a língua mãe e a da sociedade receptora. Porém, esse hibridismo, como vimos discutindo, não é uma mistura, mas uma "indecidibilidade entre línguas". Permanece-se entre a atitude do Xenos, que aprende a língua do outro, e a do bárbaro, que se recusa a tal. O resultado é um discurso explicitamente dialógico, com referências a uma língua e outra. Esta atitude de indecidibilidade linguística é interpretada pelo discurso monológico da língua dominante como degeneração linguística.

No entanto, o bilinguajamento não se restringe à questão da língua. O migrante latino-americano atua na fronteira entre dois modos de vida diferentes, o que faz com que a "sensação de não estar de todo" esteja sempre presente durante sua estadia na Europa.

A hospitalidade dentro da associação estratégica é condicional e depende, sobretudo, do domínio da língua local. Acolhe-se aquele que saiba falar a língua local ou que tenha habilidade para aprendê-la. A exigência da língua representa, segundo Derrida, a primeira violência contra o estrangeiro. A hospitalidade que 
impõe condições é uma forma de violência. A pergunta que Derrida coloca é se devemos pedir ao estrangeiro para aprender nossa língua para podermos acolhê-lo em nossa casa. Ora, se ele já falasse nossa língua, estaríamos praticando a hospitalidade incondicional ao aceitá-lo? Em outras palavras, se ele já fosse nosso semelhante, que hospitalidade ou conversão ética haveria no ato de aceitá-lo?

A associação estratégica entre União Europeia e América Latina-Caribe e a criação de uma comunidade imaginária supostamente garantiriam uma hospitalidade incondicional. Na declaração de Guadalaja, proclama-se a existência de um espaço acolhedor para o migrante, onde seus direitos humanos seriam respeitados independentemente de seu estatuto. O conceito de hospitalidade incondicional desconstroi a oposição hierárquica migrante legal/ilegal. No caso específico do migrante latino-americano, a desconstrução da dicotomia legal/ilegal passa também por uma desconstrução de várias outras oposições hierárquicas, como europeu/latino-americano, civilizado/bárbaro e Razão/Emoção. O migrante legal latino-americano é aquele que apresenta raízes europeias e modos civilizados. Um sinal de "civilização" e "racionalidade" seria a apresentação de documentos na fronteira, respeitando assim a lei do Estado receptor. Outro sinal seria sua capacidade de utilizar corretamente a língua do país receptor. Estas atitudes o definiriam como adulto, disciplinado, responsável e, portanto, confiável.

Ao contrário, o migrante ilegal latino-americano não tem vínculos de parentesco com europeus e seu comportamento é bárbaro, irracional, sem logos. Não se apresentar na fronteira, com passaporte e declaração de origem, é considerado um comportamento pueril, emotivo e impulsivo. Este tipo de migrante seria um ser que se guia pela paixão e pela emoção.

Pode-se argumentar que qualquer migrante ilegal - e não só o latinoamericano - apresenta-se hoje numa cadeia de significantes em que também surgem os termos da coluna da direita (ver abaixo). Porém, a associação do migrante ilegal latino-americano com os termos "mutante", "bárbaro", "emoção" e "canibal" tem uma dimensão simbólica significativa, pois o latino tem sido vinculado, como temos visto ao longo desta tese, exatamente com aqueles adjetivos que agora aparecem como características do migrante ilegal na contemporaneidade. Em outras palavras, aqueles termos hoje associados ao migrante ilegal foram historicamente utilizados para se referir aos latino-americanos. 


\section{Oposição Hieráquica da migração:}

$\begin{array}{ll}\text { Ordem } & \begin{array}{l}\text { latino-americano } \\ \text { “outro" bárbaro }\end{array} \\ \text { Migrante legal } & \begin{array}{l}\text { Migrante ilegal } \\ \text { Domina a linguagem }\end{array} \\ \text { Lemelhante } & \text { Fantasma } \\ \text { Razão } & \text { Emoção } \\ & \text { Canibal } \\ & \text { Fora-da-lei } \\ & \text { Doença } \\ & \text { Antropófago } \\ & \text { Mutante }\end{array}$

Podemos notar regularidades e dispersões entre o discurso das cúpulas sobre migrações e as práticas discursivas entre Europa e América Latina e Caribe nos séculos XVI, XVII, XVIII e XIX. A oposição hierárquica entre migrante legal e migrante ilegal latino-americano seria uma dispersão de outras hierarquizações. Essa "variedade na repetição", como vimos em Foucault, é dada pelas condições histórico-empíricas de uma determinada época. Nos primeiros séculos após o descobrimento, prevalecia uma visão religiosa do mundo, o que resultava numa classificação dos homens em cristãos e não-cristãos. Na contemporaneidade, a hierarquia não é mais produzida por uma visão religiosa do mundo, mas pela mobilidade.

em vez de homogeneizar a condição humana, a anulação tecnológica das distâncias temporais/espaciais tende a polarizá-la. Ela emancipa certos seres humanos das restrições territoriais (...) ao mesmo tempo que desnuda o território, no qual outras pessoas continuam sendo confinadas (Bauman, 1998, p. 25).

Assim, a distinção entre o migrante legal (aquele que pode se mover) e o migrante ilegal (o que está condenado à imobilidade) é a oposição hierárquica primordial da globalização do século XXI. No caso da associação estratégica, essa oposição hierárquica deve ser pensada no contexto da migração de latinoamericanos. A repetição de outras práticas discursivas aparecerá no tipo de rela- 
ção (hierárquica) que se estabelece entre o migrante legal latino-americano e o migrante ilegal latino-americano.

O indígena não-cristão era representado de formas diferentes por Las Casas e Sepúlveda. Para o primeiro, o indígena era "capaz de aprender", uma característica que vimos ser atribuída aos "estrangeiros" pela pólis grega. Para o segundo, o indígena era um canibal inveterado sem nenhuma chance de ser recuperado pelos ensinamentos cristãos, ou seja, ele era um "bárbaro" incapaz de aprender. As interpretações de Las Casas e Sepúlveda serão retomadas, respectivamente, na oposição migrante legal latino-americano/migrante ilegal latino-americano.

Uma outra prática discursiva do século XVI que reaparece no XX é a da associação do termo inferior da oposição hierárquica com a ideia de doença incurável. Na representação cristã, o paganismo do indígena era visto como uma doença. Para os que acreditavam na possibilidade de aprendizado do indígena, essa doença poderia ser curada por ensinamentos cristãos. Ao contrário, para os que desconfiavam da capacidade de aprendizado do indígena, como Sepúlveda, não haveria cura possível e, portanto, seria melhor exterminar os nativos do Novo Mundo.

No caso da oposição migrante legal/migrante ilegal, considera-se que o primeiro possa aprender e se adaptar às leis locais, enquanto o segundo teria dificuldades para fazê-lo. A língua e as leis da pólis substituem os ensinamentos cristãos. É o conhecimento sobre elas que poderá curar o "doente". A preguiça e a indisciplina típidas da latinidade poderiam ser "curadas" pelo aprendizado de novas regras no caso do migrante legal latino-americano, bem instruído, com alto nível de formação e disciplinado. Já o migrante ilegal latino-americano deve ser rejeitado, uma vez que sua possibilidade de "cura" ou "adaptação" é ínfima ou inexistente.

\section{6}

\section{O migrante ilegal latino-americano e o canibal: a dimensão contesta- dora}


$\mathrm{Na}$ associação estratégica, o migrante ilegal latino-americano exerceria uma função semelhante à do antropófago, do canibal e do fantasma. Ele emerge como um possível lócus de enunciação do discurso descolonizador. Sua simples presença significa uma contestação à lei e à ordem internacional baseada em Estados soberanos e em cidadanias excludentes. Sua fala traz elementos do bilinguajamento a que se refere Kathibi, ou seja, ela contempla duas linguagens e culturas distintas, trabalhando na interseção entre a cultura europeia e a cultura latinoamericana. Assim como Calibán, o migrante ilegal latino-americano é capaz de pensar a partir da fronteira, sendo esta entendida não como uma linha divisória entre dentro e fora, mas como espaço em constante reformulação. Em suma, o migrante ilegal latino-americano, considerado como um “outro bárbaro", produz a partir de um lócus de enunciação situado na fronteira.

Como vimos no capítulo 3, há semelhanças entre a desconstrução e a antropofagia em relação à ruptura de dicotomias estabelecidas, como a da divisão entre o eu e o outro. Por definição, o antropófago é um sujeito descentrado que oferece uma abertura constante ao outro, além de um acolhimento do outro.

$\mathrm{Na}$ formulação de Vera Follain de Figueiredo, o ritual antropofágico indígena é recuperado como metáfora de uma visão de mundo não excludente; a devoração implicaria o reconhecimento dos valores do outro" (Figueiredo, 2011, p. 394). Como vimos com Viveiros de Castro, o "cogito canibal” é uma topologia do devir-outro. Há aqui uma abnegação absoluta, uma abertura ao outro.

Portanto, ser antropófago é ser incondicionalmente hospitaleiro, diluindo a separação entre dentro e fora. A antropofagia apresenta-se assim como uma estratégia contra-hegemônica que se opõe a uma ordem baseada em Estados que instituem a separação dentro/fora. Ou seja, os termos antropofagia e canibalismo, que historicamente carregaram uma conotação negativa, funcionam, nesta interpretação, como operadores conceituais contra-hegemônicos.

Porém, se a antropofagia, assim como a desconstrução, dilui a fronteira entre o eu e o outro. Isto quer dizer que a antropofagia e a desconstrução permitem pensar o migrante como alguém aberto ao outro, à influência cultural da sociedade de destino. Ao mesmo tempo, ele contesta a sociedade receptora, sua abertura ao outro não significa uma aceitação acrítica do outro.

Não queremos dizer com isto que, na prática, o migrante esteja sempre aberto ao outro. Em comunidades de imigrantes muitas vezes se percebe um com- 
portamento de fechamento em relação à sociedade receptora. A vida comunitária do imigrante passa a reproduzir o modo de vida de seu país de origem. Para este migrante, a separação entre eu e outro permanece. O imigrante que se isola em sua comunidade pratica o monolinguismo da preservação de uma identidade fixa que não pode sofrer qualquer "contaminação" da sociedade receptora. Esta constatação não nos impede de considerar o potencial da desconstrução e da antropofagia para outros processos de integração do migrante.

A metáfora antropofágica de comer o outro simbolicamente merece alguns considerações pois, a princípio, pode ser interpretada de duas formas: uma antropofagia monológica ou uma antropofagia dialógica.

Se a antropofagia é definida como absorção do outro, não está claro ainda como se dá esta absorção. O acolhimento do outro significaria transformar o outro em alguém semelhante a si? Assimilar o outro de acordo com seus próprios padrões culturais? Ou a absorção do outro significa transformar-se no outro, como apontou Viveiros de Castro?

No primeiro caso, a antropofagia poderia ser caracterizada como monológica porque, apesar da deglutição do outro, há um esforço especular de transformar o outro num igual. Este processo, como anunciamos na discussão do capítulo teórico, teria embasado a exploração colonialista europeia no século XIX, a partir do discurso de uma ligação natural entre Europea e América Latina e Caribe.

A antropofagia que chamamos de monológica também está presente em discursos desenvolvimentistas, progressistas e iluministas como o da associação estratégica entre a Europeia e a América Latina e o Caribe. O discurso das cúpulas pressupõe uma semelhança de valores entre União Europeia e América Latina e Caribe. Porém, esta similaridade é resultado de um processo colonizador que caracterizamos como uma antropofagia monológica. A América Latina e o Caribe foram subsumidos sob a cultura europeia e os valores latinos, transformados em extensões da Europa. A alteridade latino-americana é completamente anulada em nome de uma narrativa monológica hegemônica.

No século XXI, este tipo de antropofagia surge, por exemplo, em políticas assimilacionistas de imigrantes. Tais políticas são baseadas numa hospitalidade condicional, ou seja, os imigrantes devem aprender e adotar a cultura do país de destino. Aceita-se e integra-se o imigrante desde que ele esteja disposto, como o estrangeiro da pólis, a aprender a língua do país receptor. 
A ideia de uma antropofagia monológica surge igualmente em algumas leituras do Manifesto antropofágico que atribuem a Oswald uma tentativa de afirmar uma identidade brasileira. Este tipo de interpretação, assim como os discursos sobre uma superioridade ibérica ou latino-americana, continuam baseados em uma estrutura discursiva monológica. Invertem a dicotomia europeu/latino, mas apenas para reproduzir um outro monologismo.

Ao contrário, numa antropofagia dialógica, temos a possibilidade de confrontação de duas ou mais vozes, de enxertos e hibridismos que se mantém no campo da indecidibilidade. Não se é isto ou aquilo, mas algo entre, situado na fronteira. Quando sugerimos que o migrante atual tem potencial para o pensamento liminar, isto se dá justamente por sua capacidade de atuar na indecidibilidade, questionando identidades fixas. No estudo de Viveiros de Castro, o "cogito canibal" caracteriza-se pela abertura ao outro. O outro é um destino, algo que se quer ser no futuro.

Porém, o migrante ilegal latino-americano, como o Calibán, é também aquele que pode, como Oswald, fazer uso de "enxertos", juntando elementos contraditórios provenientes de experiências diferentes. Os enxertos são intervenções dialógicas numa ordem instituída monologicamente. Em outras palavras, os enxertos significam uma tentativa de afrouxar o ponto nodal da narrativa hegemônica que hoje associa o migrante ilegal latino-americano à degeneração da língua ou a uma cópia do europeu. $\mathrm{O}$ enxerto busca uma ruptura da cadeia de significantes vigente e a instauração da disputa pelo significante flutuante. No caso, trata-se de decidir o significado do significante flutuante migrante latino-americano.

Vimos que o significante canibal tornou-se um significante central para entender o encontro entre a União Europeia e a América Latina. Ao longo dos séculos, ele teria deslizado no espaço não linear da différance colonial. Como explicou Jáuregui (ver capítulo 3), o canibal era o ciclope, depois um soldado de Khan, em seguida um índio bravo...O canibal não encontra "sossego semântico" (Jáuregui, 2008, p.14).

Suspeitamos que o termo canibal tenha continuado a deslizar pelos significantes fora-da-lei, não-cristão, não-humano...Deslizou pelo Calibán de Shakespeare, pelo fantasma e o bárbaro da pólis grega no texto de Derrida, pelo antropófago de Oswald de Andrade. O canibal desliza ainda para o migrante ilegal latinoamericano. Este carrega em si a dimensão desafiadora de seus predecessores. É 
ele que ocupa hoje o lugar outrora destinado ao canibal no imaginário europeu. Assim como o canibal, cujo balbucio podemos considerar como uma espécie de enxerto na linguagem do conquistador, o migrante introduz o que Kathibi chama de plurilinguajamento num mundo transnacional. Somos confrontados por outros que se mantêm na fronteira do plurilinguajamento, sem terem de escolher entre a adesão à cultura de origem ou à cultura de destino.

Ao contrário, o "migrante-antropófago-dialógico" não nutre uma veneração por sua própria cultura. Esta pode ser profanada e carnavalizada, deformada e transformada. Apesar de seu conhecido europeísmo, Jorge Luís Borges chamou a atenção para o fato de que os latino-americanos poderiam lançar mão de todos os temas europeus, utilizá-los sem superstições, com uma irreverência que não é permitida aos europeus. Ou seja, o latino-americano pode deformar o que absorve do outro.

Assim, o pensamento liminar produzido pelo imigrante ilegal latinoamericano não afirma nem um latino-americanismo completamente desvinculado da Europa nem tampouco um universalismo europeu. Defender o latinoamericanismo seria apostar numa diferenciação extrema em relação à Europa, o que nos levaria a pensar no estritamente latino-americano. Amartya Sen (ver capítulo 2) nos alerta para os riscos de se assumir tal especificidade. Por outro lado, adotar o universalismo europeu - e, consequentemente, a crença de que somos uma extensão da Europa - seria ignorar a diferença colonial que nos coloca num lócus de enunciação de discurso e de conhecimento não-eurocêntricos.

No entanto, precisamos fazer aqui uma distinção entre potencial epistemológico e capacidade de agência. Quando dizemos que o migrante ilegal latinoamericano coloca uma provocação para a Fortaleza Europa, isto não significa que esta contestação seja suficiente para conferir capacidade de agência a esse migrante. Suas condições materiais e a posição inferior que ele ocupa na oposição hierárquica da migração tornam sua voz inaudível e pouco eficaz.

A capacidade de o migrante realizar uma antropofagia dialógica provém de sua própria constituição como um sujeito descentrado. O dialogismo é possível porque, como mostrou Bakhtin, o discurso não é produto de um sujeito centrado e autônomo. Estamos subordinados a restrições que controlam nosso discurso, como, por exemplo, o "gênero de discurso". No caso do migrante, o gênero de discurso é marcado pelo enxerto, pelo improviso e pela desconstrução da fala do ou- 
tro. O suposto grunhido introduz o dialogismo no discurso monológico. Por outro lado, ele também não pode evitar falar algo na língua do outro, uma vez que não se trata de opor uma língua à outra, mas de buscar o que Khatibi chamou de plurilinguajamento. Em suma, o "gênero de discurso" do migrante seria o plurilinguajamento, um híbrido entre duas línguas.

Porém, a ideia de estar entre-línguas ou numa indecidibilidade entre línguas não deve ser interpretada, segundo Mignolo, como um bilinguismo ou plurilinguismo. O pensamento liminar demanda algo mais. É preciso levar em conta que "o linguajamento é o momento no qual uma "língua viva" (como diz Anzaldúa) se descreve como um estilo de vida (un modo de vivir) na interseção de duas (ou mais) línguas” (Mignolo, 2003, p. 358). Ou seja, o bilinguajamento não é sinônimo de bilinguismo (a habilidade de falar duas línguas). O bilinguajamento é um estilo de vida.

O bilinguajamento é possível nas fraturas da língua hegemônica; é ali que ele introduz seus enxertos, seus comentários, suas críticas... Ele permite que aqueles que não dominam a língua hegemônica num dado território possam vencer o medo e expressar-se hibridamente. Um estilo de vida antropófago ou canibal seria justamente aquele que acolhe o outro ou a língua do outro sem veneração excessiva. A língua do outro pode ser deformada, modificada, enxertada. Em outras palavras, ela pode ser profanada, o que na definição de Giorgio Agamben significa ser reconduzida ao debate público.

O migrante ilegal latino-americano, ao adotar um estilo de vida antropófago, é capaz de profanar não apenas a língua padrão, mas a história oficial e as próprias leis do lugar que o recebe. A abordagem crítica da história é frequentemente uma prática de sobrevivência intuitiva do migrante. A partir do conceito de história em Walter Benjamin, Stéphane Mosès afirma que a história dos vencedores deve ser confrontada pela memória dos "sem nome" ou pela tradição dos vencidos. Ao chegar "sem se anunciar" ou "sem apresentar seu nome na fronteira", o imigrante questiona a história do país de destino ou seu "arquivo".

A presença dos migrantes na União Europeia e seu enquadramento na Diretiva do Retorno põe em xeque uma narrativa histórica que apresenta a UE como promotora de direitos humanos e de uma ordem internacional virtuosa. No caso específico dos migrantes latino-americanos, a crítica à história oficial se torna ainda mais contundente, pois, revela uma cisão numa suposta “comunidade ima- 
ginária" que seria erigida por uma associação estratégica entre a União Europeia e a América Latina.

A “comunidade imaginária" UE-América Latina, supostamente baseada nos mesmos valores e laços históricos, representa uma formação discursiva na qual os significantes latino e europeu aparecem associados a "valores semelhantes", "atuação virtuosa no sistema internacional", "modelo a ser seguido pelos outros". A partir de um lócus de enunciação situado na fronteira, o imigrante latino-americano desestabilizará o ponto nodal daquela cadeia de significantes que une o europeu e o latino em torno dos mesmos valores. Esta cadeia de significantes hegemônica desconsidera, por exemplo, a existência de uma diferença colonial entre europeus e latino-americanos. O imigrante latino-americano provoca, portanto, uma ruptura da cadeia hegemônica ao introduzir a "diferença colonial".

Como vimos no capítulo 3, a antropofagia aproxima-se da desconstrução de Derrida e a ela acrescenta a "diferença colonial", possibilitando assim uma descolonização da desconstrução. De acordo com Walter Mignolo, a "desconstrução torna-se descolonização no espaço fraturado do bilinguismo e do bilinguajamento" (2003, p. 361). Poderíamos então dizer que desconstrução e descolonização convergem no bilinguajamento antropofágico. A contestação trazida pelo migrante une desconstrução e descolonização na crítica à narrativa hegemônica.

No entanto, devemos lembrar que a contestação trazida pelo migrante não é produto da intencionalidade de um indivíduo. Em Bakhtin, Foucault e Derrida, o sujeito não é centrado e autônomo, com controle completo sobre o discurso que profere. O bilinguajamento, como o dialogismo, também não é um processo individual. Os hidridismos linguísticos e o estilo de vida do bilinguajamento são moldados por práticas discursivas que não dependem de um único sujeito enunciador.

O descentramento do sujeito moderno na América Latina foi contestado por Eduardo Subirats a partir de uma análise do romance "Eu, o supremo", de Augusto Roa Bastos. Ao contrário dos relatos da literatura europeia do século XX sobre a desconstrução do sujeito moderno, na literatura latino-americana o sujeito está marcado, desde o início, pelo fracasso. "O protagonista dos romances de Beckett, numa obra como Molloy, conserva, apesar de sua patética autodissolução espiritual, a consistência discursiva de um ex-sujeito cartesiano ou transcendental" (Subirats, 2006, p. 93). Na interpretação de Subirats, o protagonista de "Eu, o 
supremo" nunca teria passado pela experiência do sujeito cartesiano a não ser como ficção.

Esta leitura sobre a impossibilidade de um sujeito moderno descentrado na América Latina pode nos fazer recair na tese de uma especificidade latinoamericana que nos tornaria distante de qualquer influência ou experiência europeia. Entendemos que o descentramento do sujeito moderno também é uma experiência da América Latina, porém acrescida de um reconhecimento da diferença colonial. Eduardo Viveiros de Castro mostra essa duplicidade em sua teoria sobre o perspectivismo ameríndio. Os indígenas não são destituídos de raciocínio lógico, como acreditavam antropólogos do século XIX; porém, possuem um cogito canibal e uma Metafísica canibal. A différance derridiana está presente, porém ela se transforma em "diferonça".

O migrante latino-americano, portanto, é um sujeito moderno descentrado, mas com um algo a mais: a diferença colonial. Isto é, ele permanece num entrelugar ou numa indecidibilidade entre o ser europeu e o ser latino-americano. Como apontou Sérgio Buarque de Hollanda, "somos uns desterrados em nossa terra", o que nos leva à sensação de "não estar de todo" (Süssekind). Mas o migrante latino-americano na Europa será um “desterrado pela segunda vez” (Santiago, 2006, p. 22), sendo que este segundo desterramento abrirá também a possibilidade de um bilinguajamento. Segundo Mignolo, o pensamento moderno sempre esteve atrelado a um território particular e a uma epistemologia territorial. Ao contrário, o migrante latino-americano, "desterrado", “desterritorializado" pela segunda vez, pode se constituir como um lócus de enunciação para um pensamento liminar que conteste a associação estratégica.

O descentramento e o desterramento do migrante latino-americano podem ser mais bem compreendidos se estendermos nossa análise à questão da temporalidade. O deslocamento no espaço também acarreta, para o migrante, uma ruptura temporal com o local de origem. Aquele que migra e retorna acredita poder encontrar intacto o que deixou para trás. No entanto, ao voltar para o país de origem, descobre que os outros "cresceram sob outros sóis" (Süssekind, 1990). A experiência temporal do migrante não obedece, portanto, a uma sequência linear unidirecional, pois os tempos são entrecortados pelos deslocamentos espaciais.

A narrativa moderna sobre a América Latina localizava a região num tempo circular e repetitivo. Na concepção hegeliana, ela estaria fora da História e seus 
habitantes seriam povos atrasados. Entendemos que a experiência do migrante latino-americano com o tempo se afasta tanto da temporalidade circular quanto da temporalidade linear. $\mathrm{O}$ que vemos é uma temporalidade fragmentada, com idas e vindas, rupturas, retornos, recuperações e reapropriações. No "Manifesto Antropófago" de Oswald, vimos uma temporalidade em frangalhos, anacrônica, desorganizada e que, justamente por sua desestruturação, era capaz de profanar a história oficial.

Assim, o migrante latino-americano apresenta-nos um questionamento sobre a não-contemporaneidade entre a Europa e a América Latina e o Caribe. O contemporâneo é aquele que não coincide completamente com o nosso tempo, uma vez que traz e faz referências a outros tempos e locais. Na definição de contemporaneidade de Agamben, inspirada em Nietzsche, o contemporâneo neutraliza as luzes de sua época e, por isso, consegue enxergar o lado obscuro do presente.

Em outras palavras, a presença do migrante latino-americano na União Europeia revela o lado oculto da modernidade: a colonialidade. Em vez de um processo localizado no passado, a colonialidade é recolocada como uma questão contemporânea. Consequentemente, esta interpretação sobre modernidade e colonialidade nos obriga a rever a concepção de história unilinear eurocêntrica que localiza a colonialidade no passado e a modernidade no presente. Assim como o bárbaro e o fantasma questionavam, por sua simples presença, a língua e as leis da pólis de destino, o migrante ilegal latino-americano denuncia o discurso histórico hegemônico que encerra a colonialidade no passado, como se esta tivesse sido superada pela modernidade.

A teoria da modernização também é, de certa forma, contestada pela existência do migrante latino-americano, pois este se desloca em busca de melhores condições de vida justamente por não acreditar que seu país de origem se tornará desenvolvido a curto prazo. Aqui, a temporalidade linear subjacente à teoria da modernização não mais convence: seu país de origem não fará o catch up. Esta interpretação poderia levar à conclusão de um fatalismo do migrante latinoamericano, voltando a associá-lo com a indolência que sempre aparecia nas narrativas sobre o latino-americano. Seu fatalismo e indolência o levariam a migrar. Estabelece-se assim um discurso que representa a migração como um produto do fatalismo e da falta de vontade do imigrante em construir algo em seu país de ori- 
gem. Enquanto a migração europeia era representada no século do "descobrimento" como uma aventura, um ato de empreendedorismo e busca do novo, a migração de latino-americanos para a Europa, sobretudo dos ilegais, é interpretada como uma decisão desesperada e fatalista. Todavia, o "fatalismo" que faz o migrante deixar seu país de origem não é um fundamentalismo, uma essência de sua personalidade, mas um "fatalismo provisório" que lhe permitirá o deslocamento. Uma vez estabelecido no país de acolhimento, a perspectiva fatalista sobre suas condições de vida é abandonada pelo migrante.

Podemos dizer que a teoria da modernização promove uma progressão no tempo e um congelamento no espaço. Todas as sociedades poderiam se movimentar em direção a um mesmo ideal de progresso, aquele alcançado pelos países desenvolvidos. Em contrapartida, esse deslocamento temporal, do estágio mais atrasado para o estágio mais avançado, é justamente aquilo que desautoriza a migração. Cada um deve aguardar o desenvolvimento de seu país de origem e não emigrar. A imigração dos mais atrasados para os países mais desenvolvidos representaria um fardo para estes últimos e poderia inclusive retardar o seu desenvolvimento. Neste aspecto, a chamada teoria da modernização é tradicionalista e conservadora; o ideal seria manter o status quo. O fato de a teoria da modernização ser refratária à migração está relacionado à sua própria inscrição na ordem internacional formada por Estados-nação e cidadanias nacionais.

Temos uma teoria moldada a partir dos mesmos pressupostos que definem a soberania como resolução moderna da dicotomia entre o particular e o universal. Só se pode alcançar o desenvolvimento universal - que levaria todos os países a um mesmo patamar modernizante - caso este desenvolvimento seja pensado no âmbito nacional e dirigido a cidadãos nacionais. A chegada de um cidadão de outro Estado seria, portanto, um desvio de uma ordem pensada com base na exclusividade territorial.

A relação entre a União Europeia e a América Latina e o Caribe é perpassada por oposições hierárquicas, entre elas aquele imposta pela teoria da modernização. Nesta teoria, a Europa ocupa o fim da linha de desenvolvimento e progresso e o destino da América Latina e do Caribe seria copiar o modelo instituído pela Europa. O migrante latino-americano apresenta uma provocação epistemológica a este modelo. Como vimos, ao utilizar a língua matriz, ele a recria, afirmando assim a originalidade da cópia. Além disso, por se basear numa temporalidade fra- 
gmentada, ele revela a arbitrariedade e o etnocentrismo de uma sequência temporal linear que transforma a diferença em desvio e atraso.

O discurso sobre a associação estratégica entre União Europeia e América Latina e Caribe estabelece um espaço birregional supostamente acolhedor para as populações de ambas as regiões. Ao tratar de migrações, o discurso das cúpulas reconhece o impacto positivo dos fluxos migratórios entre ambas as regiões, consideradas como irmãs. O migrante latino-americano é aquele que "testa" tais afirmações. Ao migrar para a União Europeia, o latino-americano tem a expectativa de ser recebido como um semelhante, tal como proclamava o discurso das cúpulas. No entanto, ele recebe o mesmo tratamento dispensado a qualquer outro migrante que não faça parte de uma associação estratégica com a União Europeia.

\section{6 \\ Conclusão}

A associação estratégica entre a União Europeia e a América Latina é apresentada pelos textos das Declarações de Cúpula como um projeto benigno, 
virtuoso e destinado a introduzir uma nova abordagem nas relações internacionais. A promessa seria a de estender os valores europeus e a visão europeia sobre o internacional para outras regiões, contribuindo para a criação de um mundo póscanibalismo hobbesiano.

Esta proposta só pode ser compreendida quando recorremos à já clássica discussão sobre a Ideia de Europa e sobre o papel da União Europeia na manutenção e difusão dessa ideia. A ideia de Europa, construída a partir de uma memória seletiva de fatos do passado europeu, baseia-se na defesa dos direitos humanos, do multilateralismo e da resolução de desavenças por meio da diplomacia. Os europeus seriam capazes de superar o mundo histórico hobbesiano da luta pelo poder e promover princípios cosmopolitas. A promoção desses valores por meio da política externa tornaria a UE um ator diferenciado no cenário internacional, capaz de contribuir para uma ordem mais justa do que a estabelecida pelos Estados Unidos no período pós-Guerra Fria.

Na década de 90 do século passado, a União Europeia deparou-se com a possibilidade de recuperar sua "grandeza", como apontou Miroslav, e voltar a exportar seu modo de vida. A União precisava definir seu papel internacional, mas, para isto, deveria recorrer a um aliado que, naquele momento, lhe permitisse se contrapor ao único hegemon do sistema internacional: os Estados Unidos. O discurso sobre a associação estratégica baseou-se, portanto, na semelhança de valores entre a União Europeia e a América Latina e o Caribe. As duas regiões compartilhariam um passado e uma cultura em comum. Vimos como o pronome "nós" ajudava a criar nos textos um efeito monológico, apresentando a "comunidade imaginada" UE-ALC com uma única voz consensual. Nesta leitura, a América Latina e o Caribe são o "outro do mesmo", não passam de uma extensão da Eurpa

do Ocidente, e nossos interesses na ordem internacional só poderiam ser complementares, nunca opostos.

No entanto, a América Latina e o Caribe não são propriamente aliados ou parceiros em igualdade de condições com a União Europeia. No discurso da associação estratégica, a sua posição é antes a de uma região que teria potencial para ser o primeiro receptor do modelo europeu. Em outras palavras, a América Latina e o Caribe seriam os bons alunos capazes de aprender, mais rapidamente do que os demais atores internacionais, os valores e princípios representados pela "Ideia 
de Europa". Como os indígenas de Las Casas, os latino-americanos ainda poderiam ser civilizados.

Desta forma, a América Latina e o Caribe passam de protagonistas da associação estratégica a meros coadjuvantes. Somos território dos valores europeus, mas, ao mesmo tempo, "ainda" não somos europeus. Por isso, um pouco de aprendizado daqueles valores ainda se faz necessário. Esta ambivalência da posição da América Latina e do Caribe na associação estratégica mostra uma permanência de nossa "sensação de não estar de todo". Não estamos de todo na associação estratégica.

Longe de ser um acordo entre iguais, a associação estratégica caracterizase como um projeto eurocêntrico que visa a resgatar a centralidade ocupada pela Europa até a Segunda Guerra Mundial. A proposta pressupõe uma temporalidade linear na qual o modelo europeu figuraria como o patamar mais avançado. Frases como "a Europa precisa dar o exemplo" revelam uma pretensão de voltar a ser o maior exportador líquido de ideias para o mundo. Pode-se argumentar, como fizeram Habermas e Derrida no manifesto de 2003, que, diante de um poder avassalador como o dos Estados Unidos na última década do século XX, a ideia de uma excepcionalidade internacional europeia poderia ser bem-vinda. Adotar uma "posição" contrária à invasão do Iraque era fundamental. Porém, estaríamos assim justificando um mal menor em nome da necessidade de combater uma ameaça imediata.

O programa da associação estratégica está perpassado por uma visão iluminista e modernizante do sistema internacional, o qual caminharia para um mundo kantiano indicado e antecipado pela União Europeia. Os "bens regionais" propiciados pela associação (ver lista no capítulo 4) prometem um aperfeiçoamento da ordem internacional. Este cardápio de bens seria entregue primeiro à América Latina e ao Caribe, os bons alunos, e depois estendidos aos demais.

No entanto, este projeto iluminista silencia sobre o lado obscuro da modernidade: a colonialidade. Apesar do discurso sobre a semelhança de valores, a América Latina e o Caribe ainda são um "outro" não totalmente civilizado que pode receber a ajuda proporcionada pela UE. A associação estratégica resgata desta forma pressupostos contidos na teoria da modernização, como, por exemplo, o de que as sociedades se encontram em estágios diferentes de desenvolvimento, mas caminham para um ponto no qual os países avançados já se encontram. 
Ao deixar as sombras e ganhar o primeiro plano, a colonialidade evidencia uma cisão na comunidade até então tida como harmoniosa. Não se pode continuar a falar de uma associação estratégica quando a relação União Europeia-América Latina é uma relação de oposição hierárquica. Esta cisão torna-se mais pronunciada na questão migratória pois o latino-americano deixa de ser semelhante ao europeu para tornar-se o "outro" bárbaro, o canibal que outrora representava uma ameaça aos valores da civilização. O medo do bárbaro ou canibal transformou-se no medo do migrante latino-americano. Revela-se assim a oposição hierárquica europeu/latino-americano que havia sido camuflada pelo pronome nós e seu efeito monológico.

É justamente aí, na fratura da associação estratégica, que encontramos a possibilidade de um pensamento liminar ou de uma gnose liminar produzidos a partir da fronteira e a partir da América Latina. A desconstrução antropofágica ou a desconstrução descolonizadora - vai inverter, num primeiro momento, a oposição hierárquica entre civilizado europeu e bárbaro-canibal-latino-americanoantropófago-migrante ilegal latino-americano. Mas o movimento da desconstrução não se detém aí e completa-se com o deslocamento do significado e a dissolução da barra divisória da dicotomia. Isto significa que não convém mais se reportar a uma identidade fixa canibal ou latino-americana, muito menos a uma identidade europeia imutável. O canibal não é o que se torna superior ao europeu, mas o que "engole" o europeu, diluindo a divisão entre o eu e o outro.

Não se trata aqui de afirmar uma indistinção entre europeus e latinoamericanos ou uma dissolução permanente das oposições hierárquicas. Estas continuarão se formando mesmo após o trabalho da desconstrução e serão seguidas por outras desconstruções. Dito de outra forma, às vezes, veremos uma separação entre essas duas identidades - a europeia e a latino-americana - e, em outros momentos, perceberemos uma indistinção entre ambas.

No primeiro caso, estamos diante de uma oposição hierárquica em que o termo europeu se apresenta como superior ao latino-americano. $\mathrm{Na}$ inversão da oposição hierárquica, o termo latino-americano será o detentor de qualidades superiores às dos europeus. O risco deste tipo de inversão reside numa espécie de romantismo em relação a uma especificidade latino-americanidade, que tenderia a privilegiar a emoção, o saber literário, os mitos e formas populares de conhecimento. A hipervalorização do latino-americano mantém a oposição hierárquica - 
agora invertida - e, portanto, uma separação rígida em relação a uma identidade europeia. Nesse discurso da hipervalorização, somos radicalmente diferentes dos europeus e nossas formas de conhecimento também o são. Amartya Sen ressalta a inconveniência desta tentativa de criar uma especificidade identitária. Podemos facilmente atribuir ao Ocidente o monopólio da razão e aos demais o talento para outras formas de vida.

No segundo caso, o deslocamento operado pela desconstrução dissolve a barreira de separação entre europeu e latino-americano, levando a uma indistinção entre essas identidades. Consequentemente, somos semelhantes aos europeus e nossas formas de conhecimento são um reflexo daquelas que se desenvolveram na epistemologia hegemônica. Não poderíamos então fazer referência a uma filosofia latino-americana, mas tão-só a uma filosofia feita na América Latina. O conhecimento filosófico é universal. Esta leitura também apresenta seus riscos. Não estaríamos considerando como universal o que não passa de um universalismo europeu? A indistinção entre europeu e latino-americano não silencia o papel da "diferença colonial" e da "colonialidade do saber"?

As contribuições de Dussel, Mignolo e Khatibi, entre outros, para o que seria um "outro pensamento" nos afastam dos dois polos acima discutidos. Um outro pensamento não é aquele que se relaciona aos mitos, emoções e cultura popular, mas tampouco é um pensamento moldado dentro da epistemologia hegemônica europeia. Um outro pensamento não é produzido de um lado ou outro da fronteira: na especificidade latino-americana ou no universalismo europeu. Este outro pensamento é pensamento liminar, produzido a partir da fronteira. Como a antropofagia oswaldiana, ele não imita a razão universal europeia, o que não significa desprezar a lógica. Fizemos nossa própria lógica. "Fizemos Cristo nascer na Bahia" (Andrade, 1928) e "Fizemos foi Carnaval. O índio vestido de senador do Império (...) figurando nas óperas de Alencar cheio de bons sentimentos portugueses" (loc. cit.). A lógica do pensamento liminar antropofágico é carnavalizada, híbrida, dialógica... Quando Oswald afirma que "nunca admitimos o nascimento da lógica entre nós" (loc. cit.), parece associar a "lógica" a uma epistemologia hegemônica e não negar por completo uma "lógica entre nós". Da mesma forma, a referência à "mentalidade pré-lógica para o Sr. Lévy-Bruhl estudar" (loc. cit.) soa como uma crítica a uma epistemologia moderna que considerava a mentalidade 
indígena pré-lógica. Como mostrou Viveiros de Castro, existe um cogito canibal e uma metafísica canibal.

Por conta de sua posição ambígua na associação estratégica, de seu posicionamento na fronteira, de seu descentramento, de seu bilinguajamento e "vício de fala", o migrante latino-americano teria o potencial para produzir pensamento liminar. Ele traz em si, como o estrangeiro que chega à pólis, um potencial crítico para se pensar o lugar da América Latina e do Caribe na associação estratégica. Mais: ele revela a historicidade e a contingência dessa comunidade imaginária chamada associação estratégica. Aceitar a interpretação oficial sobre a associação estratégica - a de uma "comunidade imaginária baseada nos mesmos valores" seria uma forma de perpetuar a colonialidade do saber, tomando como nosso um projeto que, a partir de uma epistemologia positivista, nos coloca na condição de objetos de uma intervenção modernizante. 


\section{Referências Bibliográficas}

AGAMBEN, Giorgio. O que é o contemporáneo? e outros ensaios. Chapecó, SC: Argos, 2009.

Profanações. São Paulo: Boitempo, 2007.

ALMINO, João. Por um Universalismo Descentrado. In: ROCHA, João Cezar de Castro; RUFFINELLI, Jorge. Antropofagia hoje? São Paulo: Realizações Editora, 2011.

AMSELLE, Jean-Loup. L'Occident Décroché. Enquête sur les postcolonialismes. Paris: Éditions Stock, 2008.

ANDERSON, Benedict. Comunidades Imaginadas. Reflexões sobre a origen e a difusão do nacionalismo. Tradução: Denise Bottman. São Paulo: Companhia das Letras, 2008.

ANDRADE, Oswald. Manifesto da Poesia Pau-Brasil. In: ROCHA, João Cezar; RUFFINELLI, Jorge (Org.) Antropofagia hoje? São Paulo: Realizações Editora, 2011.

- Manifesto Antropófago. In: ROCHA, João Cezar; RUFFINELLI, Jorge (Org.) Antropofagia hoje? São Paulo: Realizações Editora, 2011.

ALENCASTRO, Luiz Felipe. O Trato dos Viventes. Formação do Brasil no Atlântico Sul. Séculos XVI e XVII. São Paulo: Companhia das Letras, 2000.

ANTELO, Raúl. Canibalismo e Diferença. In: ROCHA, João Cezar de Castro; RUFFINELLI, Jorge (Org.) Antropofagia hoje? São Paulo: Realizações Editora, 2011.

ARAÚJO, Inês Lacerda. Formação discursiva como conceito chave para a arqueogenealogia de Foucault. Revista Aulas. Dossiê Foucault. Margareth Rago e Adilton Martins (orgs.) N. 3. Dezembro 2006/março 2007. Disponível em: http://www.unicamp.br/ aulas/pdf3/14.pdf Acesso: 12 jan. 2011.

ARAVENA, Francisco Rojas. Integración en América Latina y las relaciones con la EU. Procesos complejos con importantes oportunidades. Disponível em: http://www.camericalatina.pt/xFiles/scContentDeployer_pt/docs/articleFile190.pd f Acesso em: 20 jan. 2010. 
RENAL, Celestino del. Foro Euro Latino Americano de Centros de Análisis. Diálogo EU-ALC. Debate y conclusiones. Instituto Cervantes. Madrid, 13 de abril de 2010. Fundación Carolina. Disponível em: http://www.fundacioncarolina.es/esES/publicaciones/cuadernoscealci/Documents/ForoUE-ALC.pdf Acesso em: 15 abr. 2011.

ARMITAGE, David. Declaração de Independência. Uma história global. São Paulo: Companhia das Letras, 2011.

ASH, Timothy Garton. Não foi a maior história da nossa era. O Globo. Rio de Janeiro, 12 set. 2011. P. 26. Entrevista.

ASHLEY, Richard K. Untying the Sovereign State: a Double Reading of the Anarchy Problematique. Millennium: Journal of International Studies, 1988. ISSN 0305-8298. Vol. 17, no. 2, pp. 227-262.

BAKHTIN, M. The dialogic imagination. Four essays. Michael Holquist (Ed). Translated by Caryl Emerson and Michael Holquist. Austin: University of Texas Press, 1981.

. The problem of Speech Genres. In: EMERSON, Caryl; HOLQUIST, Michael (Ed). Speech Genres \& Other Late Essays. Texas: University of Texas, 2007.

A cultura popular na Idade Média e no Renascimento

- o contexto de François Rabelais. São Paulo: Hucitec, 1987.

BARBOZA FILHO, Rubem. Tradição e Artifício: iberismo e barroco na formação americana. Belo Horizonte: UFMG, 2000.

BARROS, Diana Luz Pessoa de. Contribuições de Bakhtin às Teorias do Discurso. In: BRAIT, Beth (Org.) Bakhtin. Dialogismo e construção do sentido. Campinas, SP: Editora da Unicamp, 2005.

BAUMAN, Zygmunt. Europa. Rio de Janeiro: Jorge Zahar Editor, 2004.

Jorge Zahar Editor, 1999.

Globalização. As consequências humanas. Rio de Janeiro:

BECK, Ulrich. Democracia de baixo para cima. O Globo, Caderno Prova \& Verso, 5 mai 2012. P.3.

BENDER, Steve. Greasers and Gringos: Latinos, Law, and the American Imagination. Nova York: New York University Press, 2003.

BHABHA, Homi. The Other Question: Difference, Discrimination and the Discourse of Colonialism. In: FERGUSON, Russell (Ed.). Out There: Marginalization and Contemporary Cultures. Nova York: New Museum of Contemporary Art, 1990. 
BIGNOTO, Newton. Tolerância e Diferença. In: NOVAIS, Adauto (org.). Civilização e Barbárie. São Paulo: Companhia das Letras, 2004.

BIGO, Didier. Frontier Controls in the European Union: Who is in Control? In:

BIGO, Didier; GUILD, Elspeth. (Ed.) Controlling Frontiers: Free Movement into and within Europe. Aldershot: Ashgate, 2005.

BLEJER, Mario. Greece must not follow Argentine example. Financial Times, Londres, maio. 2012. Disponível em: http://www.ft.com/cms/s/0/d1b420d6-a32e11e1-8f34-00144feabdc0.html\#axzz1z0QrqnKN. Acesso em: 22 mai 2012.

BODEMER, Klaus. Foro Euro Latino Americano de Centros de Análisis. Diálogo EU-ALC. Debate y conclusiones. Instituto Cervantes. Madrid, 13 de abril de 2010. Fundación Carolina. Disponível em: http://www.fundacioncarolina.es/esES/publicaciones/cuadernoscealci/Documents/ForoUE-ALC.pdf Acesso em: 15 abr. 2011.

BOLAÑO, Roberto. El Gaucho Insufrible. Espanha: Anagrama, 2004.

BONNICI, Thomas. Resistência e intervenção nas literaturas pós-coloniais. Maringá: Eduem, 2009.

BORGES, Jorge Luis. La Memoria de Shakespeare. Buenos Aires: Emecé, 2004.

Leopoldo Lugones. Buenos Aires: Emecé, 1998.

1986). Buenos Aires: Emecé Editores, 1997.

América Latina. In: STORTINI, C.R. (Org.) Dicionário de

Borges: o Borges oral, o Borges das declarações e das polêmicas. Rio de Janeiro: Bertrand Brasil, 1990.

BRAIT, Beth (Org.). Bakhtin. Dialogismo e construção do sentido. Campinas: Editora da Unicamp, 2005.

BRASILEIROS detidos em aeroporto espanhol relatam maus-tratos. 27 jan. 2009. Disponível em: http://www.abril.com.br/noticias/mundo/brasileiros-detidosaeroporto-espanhol-relatam-maus-tratos-251622.shtml Acesso em: 30 abr. 2010.

BUARQUE DE HOLANDA, Sérgio. Raízes do Brasil. São Paulo: Companhia das Letras, 1995.

CABRAL DE MELlo, Evaldo. Um imenso Portugal. São Paulo: Editora 34, 2002.

CAMPBELL, David. National Deconstruction: Violence, Identity and Justice in Bósnia. Minneapolis: University of Minnesota Press, 1998. 
Writing Security. United States Foreign Policy and the

Politics of Identity. Minneapolis: University of Minnesota Press, 1992.

CAMPBELL, Mary Baine. Travel Writing and Ethnographic Pleasure. In:

. Wonder and Science. Imagining Worlds in Early Modern Europe.

Ithaca: Cornell University Press, 1999. p. 25-67.

CAMPOS, Augusto de. Da razão antropofágica: diálogo e diferença na cultura brasileira. In: Metalinguagem e outras metas. São Paulo: Perspectiva, 1992.

CANDIDO, Antonio. Vários escritos. São Paulo: Livraria Duas Cidades, 1977.

CARDOSO, Fernando Henrique. Originalidade da cópia: A CEPAL e a ideia de desenvolvimento. In: As Idéias e seu Lugar. Ensaios sobre as Teorias do Desenvolvimento. Cadernos Cebrap no 33. Petrópolis: Editora Vozes Ltda em coedição com CEBRAP, 1980.

CASANUEVA, Héctor. Integración y Competitividad regional. Llenar de contenido la Asociación Estratégica. CELARE. Dezembro de 2006.

CIESLIK, Thomas. The Enchancement of Regional Latin American Integration in the Frame of the Strategic Association between the European Union and Latin America and the Caribbean. ISA, San Diego, 2006.

COCCO, Giuseppe. MundoBraz. O devir-mundo do Brasil e o Devir-Brasil do Mundo. São Paulo: Editora Record, 2009.

CORONIL, Fernando. The Future in Question: History and Utopia in Latin America (1989-2010). 2011. Disponível em: http://www.ssrc.org/calhoun/wpcontent/uploads/2011/08/Business-As-Usual_Chapter-9_Coronil.pdf Acesso em: 25 mar. 2012.

COVEY, Cyclone. Adventures in the Unknown Interior of America. 1542.

Disponível em: http://www.ibiblio.org/eldritch/cdv/rel.htm. Acesso em: 14 jan. 2011.

CULLER, Jonathan. Sobre a desconstrução. Teoria e crítica do pósestruturalismo. Rio de Janeiro: Record, Editora Rosa dos Tempos, 1997.

CUNHA, Eneida Leal (Org.). Leituras críticas sobre Silviano Santiago. Belo Horizonte: Editora UFMG, 2008.

CUNLIFFE, Robert. Bakhtin and Derrida: Drama and the Phoneyness of the Phonè, in Face to Face: Bakhtin in Russia and the West. Sheffield: Sheffield Academic Press, 1997.

CURTIS, James M. Michael Bakhtin, Nietzsche and Russian PréRevolucionary Thought, in Nietzsche in Rússia. Bernice Glatzer Rosenthal (Ed). Princeton, NJ: Princeton University Press, 1986. 
DE CASTRO, Juan E. Mario Vargas Llosa versus barbarism. Latin American Reserch Review. 2010. Volume 45, number 2.

DELANTY, Gerard. Inventing Europe. Idea, Identity, Reality. London: MacMillan Press, 1995.

DERRIDA, Jacques. Força de Lei. Biblioteca do Pensamento Moderno. São Paulo: Martins Fontes, 2010.

Lévy, 1997. , DUFOURMANTELlE, Anne. De l'hospitalité. Paris: Calmann-

A Farmácia de Platão. São Paulo: Editora Iluminuras, 2005.

de Janeiro: Zahar, 2004.

ROUDINESCO, Elizabeth. De que amanhã: diálogo. Rio

Mal de Arquivo: uma impressão freudiana. Trad. Claudia de Moraes Rego. Rio de Janeiro: RelumeDumará, 2001.

AutênticaEditora, 2001.

Campinas, SP: Papirus, 1991.

Limited Inc.. Trad. Constança Marcondes Cesar. . "Différance". In: Margins of Philosophy, trans. Alan Bass. Chicago: University of Chicago Press, 1982.

Press, 1976.

Of Grammatology. Maryland: Johns Hopkins University

Uma Europa da esperança. Le Monde Diplomatique.

Disponível em: diplomatique.uol.com.br/acervo.php?id=1056\&tipo. Acesso em: 15 jun. 2010.

. Declarations of Independence. Disponível em: http://blog.lib.umn.edu/cole0384/academics/files/Derrida.PDF Acesso em: 30 jun. 2011 .

DÍAZ-GUERRERO, Rogelio.; SZALAY, L.B. El mundo subjetivo de mexicanos y norteamericanos. México: Trillas, 1993.

DOTY, Roxanne Lynn. Foreign Policy as Social Construction: a post-positivist analysis of U.S. Counterinsurgency Policy in the Philippines. International Studies Quarterly. (1993) 37, 297-320. In: Imperial Encounters. Coleção Borderlines. Minneapolis: University of Minnesota Press, 1996.

DREYFUS, RABINOW. Michel Foucault: Beyond Structuralism and Hermeneutics (Paperback). Chicago: University of Chicago Press, 1983. 
$\overline{\text { Universitária, } 1995 .}$

Michel Foucault, uma Trajetória Filosófica. Forense

DUQUE-ESTRADA, Paulo Cesar (org.) Às margens. A propósito de Derrida. Rio de Janeiro: Editora PUC-Rio; São Paulo: Loyola, 2002.

DUSSEL, Enrique. Europe, Modernity and Eurocentrism. Position Papers. 2000. Duke University Press. Disponível em: http://www.unc.edu/ aescobar/wan/wandussel.pdf Acesso em: 30 jan. 2012.

ECO, Umberto. An Uncertain Europe between rebirth and decline. In: Old Europe, New Europe, Core Europe. New York: Verso, 2005.

ELBE, Stefan. We Good Europeans: Genealogical Reflections on the Idea of Europe. Millenium Journal of International Studies, 2001, ISSN 0305-8298. Vol. 30, No. 2, pp. 259-28. Disponível em: http://www.stefanelbe.com/resources/wegoodeuropeans.pdf Acesso em: $20 \mathrm{dez}$. 2011.

ELIAS, Norbert. O Processo Civilizador: uma história dos costumes. Rio de Janeiro: Jorge Zahar, 1994.

ELLIOTT, Larry. Greece should follow Argentina's lead. As Argentina's experience after 2002 shows, when an economic crisis hits it is often best to go it alone. The Observer, Londres, maio. 2012. Disponível em: http://www.guardian.co.uk/business/2012/may/13/greece-argentina-economiccrisis-comparison Acesso em: 15 mai. 2012.

ENESCOA, Ileana; PARADELAA, Isabel; GUERREROA, Silvia. Stereotypes and Beliefs about Different Ethnic Groups in Spain: A Study with Spanish and Latin American Children Living in Madrid. 13 de set. de 2005. Departamento de Psicologia Evolutiva y de la Educación, Universidad Complutense de Madrid. Disponível em: http://www.eric.ed.gov/ERICWebPortal/search/detailmini.jsp? nfpb=true\&_\&ER ICExtSearch_SearchValue_0=EJ724227\&ERICExtSearch_SearchType_0=no\&ac cno=EJ724227. Acesso em: 10 mai 2012.

ESCOBAR, Arturo. Encoutering Development. The Making and unmaking of the Third World. Princeton: Princeton University Press, 1995.

Power and Visibility: Development and the Invention and Management of the Third World. Cultural Anthropology, Vol. 3, No. 4 (Nov., 1988), pp. 428-443.

EUROPEUS querem controlar fronteiras. Ministros fazem acordo para reforma que restringe livre circulação entre países do Tratado de Schengen. O Globo. Rio de Janeiro 8 jun. 2012. P. 32.

EVANS, Fred. Genealogy and the problem of affirmation in Nietzsche, Foucault and Bakhtin. Philosophy \& Social Cristicism. Disponível em: http://psc.sagepub.com/cgi/content/abstract/27/3/41. Acesso em: 8 jul. 2010.

FERES JÚNIOR, João. A História do conceito de "Latin America" nos Estados Unidos. Bauru: USC, 2005. 
FERNÁNDEZ RETAMAR, Roberto. Algunos usos de civilización y barbarie. Casa de las Americas 102 (may-june), 1977, pp. 29-52.

FIGUEIREDO, Vera Follain. Antropofagia: uma releitura do paradigma da razão moderna. IN: RUFFINELLI, Jorge, ROCHA, João Cesar de Castro (Org.) Antropofagia hoje? São Paulo: Realizações Editora, 2011.

FOUCAULT, Michel. História da Loucura. Tradução de José Teixeira Coelho. São Paulo: Perspectiva, 2003.

FOUCAULT, Michel. A ordem do discurso. São Paulo: Edições Loyola, 1996.

1971.

A Arqueologia do Saber. Petrópolis: Editora Vozes,

Poder e Saber. In: MOTTA, Manoel Barros (Org.). Estratégia, Poder-Saber. $2^{a}$ edição. Tradução Vera Lucia Avellar Ribeiro. Rio de Janeiro: Forense Universitária, 2010.

Poder. Rio de Janeiro: Graal, 1979.

FRERES, Christian, SANAHUJA, José Antonio. Hacia una nueva estrategia en las relaciones Unión Europea-America Latina. Instituto Complutense de Estudios Internacionales. Disponível em: Disponível em: http://eprints.ucm.es/11850/1/PP01-06.pdf Acesso em: 1 abr. 2011.

FUENTES, Carlos. A América Latina e a Europa. Le monde diplomatique. Novembro de 2003. Disponível em: http://diplo/uol.com.br/2003-11,a790. Acesso em: 20 ago. 2007.

GARDINER, Michael. O carnaval de Bakhtin: a utopia como crítica. In: RIBEIRO, Ana Paula Goulart; SACRAMENTO, Igor (Org.) Mikhail Bakhtin. Linguagem, cultura e mídia. São Paulo: Pedro \& João Editores, 2010.

GLYNOS, Jason et al. Discourse Analysis: Varieties and Methods. Centre for Theoretical Studies in the Humanities and Social Sciences. University of Essex. August 2009. National Centre for Research Methods. Disponível em: http://eprints.ncrm.ac.uk/796/1/discourse_analysis_NCRM_014.pdf Acesso em: 20 jun. 2011.

GLYNOS, Jason, HOWARTH, David. Critical Explanation in Social Science: a Logics Approach. In: Swiss Journal of Sociology, 34, p.5-35.

GOWAN, Peter, ANDERSON, Perry (Eds.) The question of Europe. London: Verso, 1997.

GRATIUS, Susanne, SANAHUJA, José Antonio. Entre el olvido y la renovación: la UE y América Latina. Vol. 24, № 135, 2010, págs. 122-134. 
Disponível em: http://www.politicaexterior.com/2010/04/entre-el-olvido-y-larenovacion-la-ue-y-america-latina/ Acesso em: 15 abri. 2011.

GREER, Margaret. Imperialism and Anthropophagy in Early Modern Spanish Tragedy: The Unthought Known. In: CASTILHO, David; LOLLINI, Massimo (Eds). Reason and its others. Italy, Spain and the New World. Tennessee: Vanderbilt University Press, 2006.

GREVI, Giovanni. The rise of strategic partnerships: between interdependence and power politics. In: Partnerships for effective multilateralism: EU relations with Brazil, China, India and Russia. Chaillot Paper 109, May 2008.

GRILLO, Sheila Vieira de Camargo. A noção de campo nas obras de Bourdieu e do círculo de Bakhtin: suas implicações para a teorização dos gêneros do discurso. Revista Anpoll. São Paulo: v.19, 2005, pp.151-184.

GUILD, Elspeth, “The Europeanisation of Europe's Asylum Policy," International Journal of Refugee Law, 18 (2006): 630-651.

GUMBRECHT, Hans Ulrich. Mordendo você suavemente. Um comentário sobre o Manifesto Antropófago. In: RUFFINELLI, Jorge, ROCHA, João Cesar de Castro (Org.) Antropofagia hoje? São Paulo: Realizações Editora, 2011.

GURRIARÁN, José Antonio. Relações diante de nova ordem mundial. Disponível em: http://www.mwglobal.org/ipsbrasil.net/nota.php?idnews=5879. Acesso em: 30 jan. 2011.

HABERMAS, Jürgen, DERRIDA, Jacques. February 15, or, What Binds Europeans Together: Plea for a Common Foreign Policy, Beginning in Core Europe. In: Old Europe, New Europe,Core Europe. New York: Verso, 2005.

HADDOCK LOBO, Rafael. Derrida e Foucault: Éticas sem virada. Disponível em: http://revistacult.uol.com.br/home/2010/04/derrida-e-foucault-eticas-semvirada/ Acesso em: 15 fev. 2011.

HANKE, Lewis. History of Latin American Civilization: sources and interpretations. Boston: Little Brown, 1973.

HARBSMEIR, Michael. Early Travels to Europe: Some Remarks on the Magic of Writing. In: Francis Barker et al (Eds). Europe and its others. Colchester: University of Essex, 1985.

HATTRELL, Felicity. Redefining the Limits of Refugee Protection? The Securitised Asylum Policies of the Common European Asylum System. Thesis, University of Canterburry, 2010. Disponível em: http://ir.canterbury.ac.nz/handle/10092/5311 Acesso em: 10 mai. 2012.

HERÓDOTO. História. São Paulo: Ediouro, 2001.

HIRSCHMAN, Albert. Auto-subversão. São Paulo: Companhia das Letras, 1996.

HOBSBAWN, E., RANGER, T. (orgs.). A invenção das tradições. Rio de Janeiro: Paz e Terra, 1984.

HOFFMAN, Stanley. Europe's Identity Crisis Revisited. Daedalus 123, no. 2 (1994): 1, pp. 15 e 18. 
HOLQUIST, Michael. Dialogism: Bakhtin and His World. London: Routledge, 1990. The Surd Heard: Bakhtin and Derrida. In: MORISON, Gary Saul (Ed.) Literature and History: Theoretical Problems and Russian Case Studies. Stanford: Stanford University Press, 1986.

HUNTINGTON, Samuel. Who Are We? The Challenges to America's National Identity. New York: Simon \& Schuster, 2004.

IGLESIAS, Enrique. A Europa trai a si mesma, 20 jun. 2008. Disponível em: http://www.rnw.nl/portugues/article/europa-trai-si-mesma. Acesso em: 20 mar. 2012.

INAYATULLAH, Naeem, BLANEY, David. International Relations and the problem of difference. New York and London: Routledge, 2004.

JAMES, Henry. Daisy Miller. UK: Penguin Books, 1995.

The Europeans. UK: Penguin Books, 1995.

The Americans. UK: Penguin Books, 1995.

JÁUREGUI, Carlos. Canibalia: canibalismo, calibanismo, antropofagia cultural y consumo en América Latina. Madrid: Iberoamericana, 2008.

JOHNSTONE, Barbara. Discourse Analysis. Oxford: Blackwell Publishing, 2008.

JUDT, Tony. Postwar. A History of Europe since 1945. Nova York: Penguin Books, 2005.

KAGAN, Robert. Do paraíso e do poder. A América e a Europa na Nova

Ordem Mundial. Rio de Janeiro: Rocco, 2003.

KANT, Immanuel. A Paz Perpétua. São Paulo: Perspectiva, 2004.

KHALIQ, Urfan. Ethical Dimensions of the Foreign Policy of the European Union. A Legal Appraisal. Cambridge: Cambridge University Press, 2008.

KIAROSTAMI, Abbas. Cópia Fiel. Diretor: Abbas Kiarostami. Roteiro: Abbas Kiarostami

Produção: Angel Barbagallo, Charles Gillibert, Marin Karmitz, Nathanaël Karmitz, Abbas Kiarostami. Ano de lançamento: 2010 106min.

KOHN, Margaret, MCBRIDE, Keally. Political Theories of decolonization. Postcolonialism and the Problem of Foundations. Oxford: Oxford University Press, 2011.

KRAEMER, Celso. Ética e Liberdade em Michel Foucault. Uma leitura de Kant. São Paulo: Fapesp, Educ, 2011.

KRISTEVA, Julia. Word, Discourse and Novel. In: MOI, Toril (Ed.). The Kristeva Reader. Oxford: Backwell, 1986. 
LA CAPRA, Dominick. History in Transit.Experience, Identity, Critical Theory. Cornell University Press, 2004.

. History and Reading. Tocqueville, Foucault, French Studies.

Toronto: University of Toronto Press, 2000.

LACLAU, Ernesto. Debates y Combates: por un nuevo horizonte de la politica. México: Fondo de Cultura Economica de España, 2008.

2006, 11:2,103-114.

Ideology and post-marxism. In: Journal of Political Ideologies,

LACLAU, Ernesto, MOUFFE, Chantal. Hegemony and Socialist Strategy: Towards a Radical Democratic Politics. London: Verso, 1985.

LAIGLESIA, Juan Pablo. Relaciones de la UE y América Latina - La Presidencia española impulsa dar una nueva dimensión a las relaciones UE-ALC. Jornal Nación. 11 fev. $2010 . \quad$ Disponível em: http://wvw.nacion.com/ln_ee/2010/febrero/11/opinion2260415.html Acesso em: 17 mai 2010.

LATINOAMERICANOS en tránsito. Migración, Mitos y fronteras. NUEVA SOCIEDAD 233 Mayo - Junio 2011. Disponível em: http://www.nuso.org/revista.php?n=233

Acesso em: 20.set.2012.

LEONARD, Mark. What Does China Think? London: Fourth Estate, 2008.

Fourth Estate, 2005.

LIEBIG, Thomas. Migration in the Post-Crisis World. Documento elaborado pela OCDE. International Migration Outlook, 2011. Disponível em: http://www.oecd.org/dataoecd/37/40/48367613.pdf Acesso em: 20 mai 2012.

LISZCZYK, Dorota. Strategic Partnership as an Instrument of the European Union's Foreign Policy. Bulletin n. 127. October 22, 2010. The Polish Institute of International Affairs (PISM). Disponível em: http://www.pism.pl/bulletin/a2032010.pdf. Acesso em: 30 nov. 2011.

LOCK, Charles. Double Voicing, Shaking Words: Bakhtin's Dialogism and the History of the Theory of Free Indirect Discourse. In: BRUHN, Jorge; LUNQUIST, Jan (Eds). The novelness of Bakhtin. Perspectives and Possibilities. Copenhagen: Museum Tusculanum Press, University of Copenhagen, 2001.

LOCKE, John. O Contrato Social. São Paulo: Nova Cultural, 1991.

MACCANNELL, Juliet Flower. The Temporality of Textuality: Bakhtin and Derrida. MLN Vol. 100. Comparative Literature, dec. 1985, Pp. 968-988. The 
John Hopkins University Press. Disponível em: http://www.jstor.org/stable/2905440. Acesso: 02 jun. 2010.

MADUREIRA, Luís. Intenção Carnavalesca de ser canibal ou: como (não ler) o manifesto antropófago. In: RUFFINELLI, Jorge, ROCHA, João Cesar de Castro. (Org.). Antropofagia hoje? São Paulo: Realizações Editora, 2011.

MAIHOLD, Günther. Relations between Europe and Latin America: in search of New Agendas and Formats. Working Paper, 43/2007. Real Instituto Elcano. Disponível em: http://www.realinstitutoelcano.org/documentos/WP2007/WP432007_Maihold_Europe_Latin_America_Agenda.pdf Acesso em: 15 abr. 2011.

MALAMUD, Carlos. As relações entre a União Europeia e a América Latina no século XXI: entre o voluntarismo e a realidade. Plataforma Democrática. 2010. Disponível em: http://www.plataformademocratica.org/Arquivos/As\%20relacoes\%20entre\%20a\% 20Uniao\%20Europeia\%20e\%20a\%20America\%20Latina\%20no\%20seculo\%20X XI.pdf Acesso em: 15 abr. 2011.

MANZINI, Gabriela. "Ri ao ouvir embaixador dizer que Barajas não é prisão", diz brasileiro. Folha de São Paulo, 10 mar. 2008. Disponível em: http://www1.folha.uol.com.br/folha/cotidiano/ult95u380425.shtml Acesso em: 28 mar. 2008.

MARCHART, Olivier. El pensamiento politico posfundacional. La diferencia política en Nancy, Lefort, Badiou y Laclau. Traducción de Marta Delfina Alvarez. Buenos Aires: Fondo de Cultura Econômica, 2009.

MARQUAND, David. The end of the West. The once and future Europe. Princeton, Princeton University Press, 2011.

MARQUEZ, Gabriel Garcia. Cem Anos de Solidão. São Paulo: Folha de S. Paulo, 2003.

MARTIN-BARÓ, Ignacio. The lazy latino: The ideological nature of Latin American fatalism. In: ARON, A. \& CORNE, S. (Eds.), Writings for a liberation psychology. Cambridge, USA: Harvard University Press, 1996.

MERQUIOR, José Guilherme. El Otro Occidente. In: AROCENA, Felipe; DE LEON, Eduardo (Org.) El Complejo de Propero - Ensayos sobre Cultura, Modernidad y Modernización em America Latina. Montevideo: Vintén Editora, 1993.

MILOVIC, Miroslav. A condição humana na modernidade. Revista Cult, 2007, pag. 47.

MIGNOLO, Walter D. Histórias Locais/Projetos Globais. Colonialidade, saberes subalternos e pensamento liminar. Belo Horizonte: Editora UFMG, 2003. 
A Idea de América Latina. La herida colonial y la opción decolonial. Barcelona: Gedisa Editorial, 2007.

MOMPEL, Mariona Vivar. Immigration : 1'UE blindée contre les 'invasions barbares'. Disponível em : http://www.cafebabel.fr/article/18498/immigration-lueblindee-contre-les-invasions-barba.html Acesso em: 20 mai 2012.

MONTAIGNE, Michel de. Dos canibais. In: Ensaios. São Paulo: Abril Cultural, 1978 .

MONTEIRO, Joyce Anne Rodrigues. Dupla cidadania em uma Europa globalizada: Portugal e os desafios dos novos fluxos migratórios. 2006. Tese (Doutorado em Doutorado em Relacoes Internacionais) - Instituto de Relacoes Internacionais da PUC/Rio.

MORAlES, Evo. Letter from the President of Bolivia, Evo Morales, on the EU immigration policy. 10 Jun. 2008. Disponível em: http://www.gopetition.com/petitions/evo-morales-eu-immigration-policy.html Acesso em: 15 abr. 2012.

MORO, Alfonso. La Unión Europea a la deriva. Relaciones EU-América Latina: para acabar com el mito del "buen vecino". http://www.vientosur.info/articulosabiertos/VS110_UE-America_Moro.pdf

Acesso em: 20 dez. 2011.

MORRIS, Ian. Here comes the East. The New York Times, 21 dez. 2010. Disponível em: http://www.nytimes.com/2010/12/22/opinion/22ihtedmorris22.html Acesso em: 26 set. 2011.

MOSES, Jonathon. International Migration: Globalization's Last Frontier. Nova York: Zed Books, 2006.

MOSÈS, Stéphane. L'ange de l’histoire: Rosenzweig, Benjamin, Scholem. Paris: Seuil, 1992.

MUSCHG, Adolf. Core Europe: Thoughts about the European Identity. In: Old Europe, New Europe,Core Europe. New York: Verso, 2005.

NAIR, Sami. A Europa trai a si mesma, 20 Jun. 2008. Disponível em: http://www.rnw.nl/portugues/article/europa-trai-si-mesma. Acesso em: 20 nov. 2011.

NEUMANN, Iver. Uses of the Other. "The East" in European Identity Formation. Minneapolis: University of Minnesota Press, 1999.

NEWMAN, Abraham. Austerity and the End of the European Model. How Neoliberals Captured the Continent. Foreign Affairs, Nova York, maio. 2012. Disponível em: http://www.foreignaffairs.com/articles/137611/abraham-newman/austerity-andthe-end-of-the-european-model Acesso em: 5 mai. 2012. 
NOCENTELLI-TRUET, Carmen. Canibais Devorados: Lévy, Montaigne e Identidades Coletivas na França do Século XVI. In: RUFFINELLI, Jorge; ROCHA, João Cezar de Castro (Org.) Antropofagia hoje? São Paulo: Realizações Editora, 2011.

NOVAES, Adauto (org.). Oito visões da América Latina. São Paulo: Editora Senac São Paulo, 2006.

OBEYESEKERE, Gananath. Cannibal talk: the man-eating myth and human sacrifice in the South Seas, Berkeley/Los Angeles, University of California Press, 2005 .

PADILLA, Beatriz, PEIXOTO, João. Latin American Immigration to Southern Europe. Migration Information Source, Jun. 2007. Disponível em: http://www.migrationinformation.org/Feature/display.cfm?id=609 Acesso em: 30 ago. 2011.

PAGDEN, Anthony. The Fall of Natural Man: the american Indian and the Origins. Cambridge: Cambridge University Press, 1986.

PALACIO, Vicente. Spain's Contribution to a European Vision for the Americas: a Review. In: ROY, Joaquín; LORCA-SUSINO, Maria (eds). Spain in the European Union: the First Twenty-Five Years (1986-2011). Miami: ThomsonShore, 2011.

PAPAHELAS, Alexis. The task appears Sisyphean. But don't write Greece off. The Guardian, $\quad 6 \quad$ mai 2010. http://www.guardian.co.uk/commentisfree/2010/may/06/greece-debt-crisis-nationbuilding. Acesso em: 10 mar. 2012.

PÉREZ, Claudí, MORA, Miguel. "Merkozy" contra Schengen. Alemanha e França pedem reforma em tratado europeu para retomarem controle fronteiriço. El País, publicado por $\mathbf{O}$ Globo, 20 abr. 2012, p. 30.

PERRONE-MOISÉS, Leyla. Paradoxos do nacionalismo literário na América Latina. Estudos Avançados. vol.11 n.30 São Paulo Mai/Ago. 1997 Disponível em: $\quad$ http://www.scielo.br/scielo.php?script=sci_arttext\&pid=S010340141997000200015 Acesso em: 20 mar. 2012.

PESCHANSKI, Catherine. "Os bárbaros em confronto com o tempo". In: CASSIN, Bárbara ET AL. Gregos, bárbaros, estrangeiros: a cidade e seus outros. São Paulo: Editora 34, 1993.

POSTREL, Virginia. Border War- citizenship of ilegal immigrant's children. Outubro de $1993 . \quad$ Disponível em: http://findarticles.com/p/articles/mi_m1568/is_n5_v25/ai_14536855/. Acesso em: 10 fev. 2012.

PRATT, Mary Louise. Ojos Imperiales. Literatura de viajes y transculturación. Buenos Aires: Fondo de Cultura Económica, 2011. 
QUIJANO, Aníbal. Colonialidade do poder, eurocentrismo e América Latina. In: LANDER, E. (Coord.). A colonialidade do saber: eurocentrismo e ciências sociais - perspectivas latino-americanas. Buenos Aires: Clacso, 2005.

; WALLERSTEIN, Immanuel. Americanity as a concept, or the

Americas in the modern world-system. Disponível em: http://www.jhfc.duke.edu/icuss/pdfs/QuijanoWallerstein.pdf Acesso em: 15 jun. 2011.

RENARD, Thomas. Strategy Wanted: The European Union and Strategic Partnerships. Security Policy Brief. N. 13, september 2010. Disponível em: http://www.egmontinstitute.be/papers/10/sec-gov/SPB13-EU-Strategic-

Partnerships.pdf Acesso em: 11 jan. 2011.

RETAMAR, Roberto Fernández. Calibán. Apuntes sobre la cultura de nuestra América. Disponível em: http://www.literatura.us/roberto/caliban2.html Acesso em: 14 nov. 2001.

ROCHA, João Cezar de Castro. Os canibais de Montaigne eram franceses. Disponível em: http://canibalismoeantropofagia.blogspot.com/p/os-canibais-demontaigne-eram-franceses.html. Acesso em: 10 ago. 2011.

ROLNIK, Suely. Esquizoanálise e Antropofagia. In: Gilles Deleuze. Uma vida filosófica. São Paulo: Editora 34, 2000.

ROUANET, Sergio Paulo. Manifesto Antropófago II. Oswald de Andrade. In: RUFFINELLI, Jorge; ROCHA, João Cezar de Castro (Org.) Antropofagia hoje? São Paulo: Realizações Editora, 2011.

ROUANET, Maria Helena. Quando os bárbaros somos nós. In: RUFFINELLI, Jorge; ROCHA, João Cezar de Castro (Org.) Antropofagia hoje? São Paulo: Realizações Editora, 2011.

ROUQUIÉ, Alain. América Latina. Introducción al Extremo Occidente. Madrid: Editorial Siglo XXI, 2000.

SAID. Edward W. Orientalismo. O Oriente como invenção do Ocidente. São Paulo: Companhia das Letras, 2007.

SAMUELSON, Robert. The Real China Threat. The Washington Post. 20 ago. 2008. Disponível em: http://www.washingtonpost.com/wp/19/AR2008081902256.html Acesso em: 26 set. 2011.

SANAHUJA, José Antonio. The European Union and Latin América: the common agenda after the Lima Summit. ICEI Paper. Instituto Complutense de Estudios Internacionales. Disponível em: http://aei.pitt.edu/11927/01/ICEIpaper07-_trad_English.pdf. Acesso em: 26 set. 2011.

SAntiago, Silviano. As raízes e o labirinto da América Latina. Rio de Janeiro: Rocco, 2006. 
O entre-lugar do discurso latino-americano. In: Uma

literatura nos trópicos: ensaios sobre dependência cultural. São Paulo: Perspectiva, 1978.

SANTIAGO, Silviano. (Org.) Glossário de Derrida. Rio de Janeiro: F. Alves, 1976.

SANTOS, Wanderley Guilherme. O Paradoxo de Rousseau. Uma interpretação democrática da Vontade Geral. Rio de Janeiro: Rocco, 2007.

SARAMAGO, José. Jangada de Pedra. São Paulo: Companhia das Letras, 2006.

SARMIENTO, Domingo F. Facundo: civilización y barbarie. Madrid: Alianza, 1970.

. Conflicto y armonías de las razas en América. (Tomo

XXXVIII) Obras Completas. Buenos Aires: Luz del día, 1953.

SEN, Amartya. Identity and Violence. The illusion of destiny. London, New York: W.W. Norton \& Company. 2006.

July 21, 1997.

Human Rights and Asian Values, The New Republic, July 14-

SCHWARZ, Roberto. Ao vencedor as batatas. Coleção Espírito Crítico, Duas cidades. São Paulo: Editora 34. 2003.

SLOTERDIJK, Peter. Se a Europa despertar. São Paulo: Estação Liberdade, 2002.

SOLIMANO, Andrés. International Migration in the Age of Crisis and Globalization. Cambridge: Cambridge University Press, 2010.

SOLODKOW, David. Racismo y Nación: Conflictos y (des)armonías identitarias en el proyecto nacional sarmientino. Revista Decimonónica. Revista de Producción Cultural Hispánica Decimonónica Volume II, número 1, 2005. Utah University State.

SOUZA, Nabil Araújo de. Jorge Luis Borges e o desarquivamento do saber ocidental.

Disponível

em: http://periodicos.letras.ufmg.br/index.php/caligrama/article/view/229/182 Acesso em: 20 abr. 2012.

SOUZA SANTOS, Boaventura de. Do pós moderno ao pós colonial. Disponível em: http://www.ebah.com.br/content/ABAAAASIMAC/pos-moderno-ao-poscolonial\# Acesso em: 4 mar. 2012.

STAROBINSKI, Jean. Le mot civilisation. In: Le temps de la réflexion. Paris: Gallimard, 1983. 
SUBIRATS, Eduardo. Viagem ao Fim do Paraíso. In: NOVAES, A (Org.) Oito visões sobre a América Latina. São Paulo: Editora Senac São Paulo, 2006.

SÜSSEKIND, Flora. O Brasil não é longe daqui. São Paulo: Companhia das Letras, 1990.

STEINER, George. A Ideia de Europa. Lisboa: Gradiva, 2004.

TOCCI, Nathalie (Ed.). Who is a Normative Foreign Policy Actor? The European Union and its Global Partners. Bruxelas: Centre for European Policy Studies (CEPS), 2008.

TODOROV, Tzvetan. A Conquista da América. São Paulo: Martins Fontes, 2003.

TORRENT, Ramón. La utilidad de las cumbres UE-ALC. BBC Mundo, 11 mai. $2006 . \quad$ Disponível em: http://news.bbc.co.uk/hi/spanish/international/newsid_4762000/4762547.stm Acesso em: 30 abr. 2010.

TRAVERSO, Enzo. L'Histoire comme champ de Bataille. Interpréter les violences du XX siècle. Paris: La Découverte, 2011.

ÚBEDA, José Escribano Português. Veinte Años de Relaciones entre Espana e Iberoamérica en el marco de la Unión Europea. (1986-2006). Espanha: Vision Libros, 2007.

VELASCO, Suzana de Souza Lima. A imigração na União Europeia. Uma leitura crítica a partir do nexo entre securitização, cidadania e identidade transnacional. Dissertação de Mestrado apresentado ao programa do Instituto de Relações Internacionais da PUC-Rio. Agosto de 2011.

VIVEIROS DE CASTRO, Eduardo. O mármore e a murta: sobre a inconstância da alma selvagem. In: A inconstância da alma selvagem. São Paulo: Cosacnaify, 2011.

Zahar, 1986.

Araweté: Os Deuses Canibais. Rio de Janeiro: Jorge

WALKER, R. After the Globe/Before the World. London: Routledge, 2010.

Inside/Outside: International Relations as Political Theory.

Cambridge: Cambridge Studies in International Relations, 1993.

WALLERSTEIN, Immanuel. O universalismo europeu. A retórica do poder. São Paulo: Boitempo Editorial, 2007.

WILLIAMS, Raymond. Palavras-chave [um vocabulário de cultura e sociedade]. São Paulo: Boitempo Editorial, 2007. 
WOLF, Francis. Quem é bárbaro? In: NOVAES, Adauto (Org.) Civilização e Barbárie. São Paulo: Companhia das Letras, 2004.

YOUNG, Iris. Europe and the global south: towards a circle of equality.

OpenDemocracy, ago. 2003. Disponível em: http://www.opendemocracy.net/debates/article-3-51-1438.jsp Acesso em: 20 nov. 2010.

ZIZEK, Slavoj. Política anti-imigração: Barbarismo com aparência humana. Disponível em: http://boitempoeditorial.wordpress.com/2011/08/01/politica-antiimigracao-barbarismo-com-aparencia-humana/ Acesso em: 25 dez. 2010.

\section{Documentos:}

EU-LATIN AMERICA: Global players in Partnership, 2009

Disponível em: http://www.eeas.europa.eu/la/docs/com09_495_en.pdf Acesso em: 10 jan. 2011.

STRONGER PARTNERSHIP BETWEEN THE EUROPEAN UNION AND LATIN AMERICA, 2005

Disponível em: http://eeas.europa.eu/la/docs/com05_636_en.pdf Acesso em: 10 jan. 2011.

EUROPEAN SECURITY STRATEGY (ESS), de 2003. Disponível em: http://www.consilium.europa.eu/uedocs/cmsUpload/78367.pdf Acesso em: 5 abr. 2011.

DECLARAÇÃO DO RIO DE JANEIRO Disponível em: http://ec.europa.eu/external_relations/lac/rio/rio_1999_en.pdf Acesso em: 10 jan. 2008.

DECLARAÇÃO DE MADRI. Disponível em: http://ec.europa.eu/external_relations/lac/madrid/dec_02_en.pdf Acesso em: 10 jan. 2008.

DECLARAÇÃO DE GUADALAJARA. Disponível em: http://ec.europa.eu/external_relations/lac/guadalajara/decl_polit_final_en.pdf Acesso em: 10 jan. 2008.

DECLARAÇÃO DE VIENA. Disponível em: http://ec.europa.eu/external_relations/lac/vienna/declaration_en.pdf Acesso em: 10 jan. 2008.

DECLARAÇÃO DE LIMA. Disponível em: http://ec.europa.eu/external_relations/lac/docs/declaration_en.pdf Acesso em: 10 ago. 2008.

DECLARAÇÃO DE MADRI. Disponível em: http://www.urgeotraeuropa.org/mm/file/Declaracao\%20Madrid\%20Final_PT.pdf Acesso em: 4 jun. 2010. 
CONGRESSIONAL RESEARCH SERVICE. Is China a Threat to the US Economy ? Disponível em: http://www.fas.org/sgp/crs/row/RL33604.pdf. Acesso em: 20 nov. 2011.

CONVENÇÃO INTERNACIONAL SOBRE A PROTEÇÃO DOS DIREITOS DOS TRABALHADORES MIGRANTES E SUAS FAMÍLIAS. Disponível em: http://www.oas.org Acesso em: 10 nov. 2010.

\section{Sites:}

International Organization for Migration (IOM).

http://www.oas.org/atip/migration/iom\%20report\%20migration\%20lac\%20to\%20 eu.pdf

Eurostat.

http://epp.eurostat.ec.europa.eu/statistics_explained/index.php/Migration_and_mi grant_population_statistics

http://epp.eurostat.ec.europa.eu/cache/ITY_OFFPUB/KS-SF-11-001/EN/KS-SF11-001-EN.PDF

OECD (2012), International Migration Outlook 2012, OECD Publishing. http://dx.doi.org/10.1787/migr_outlook-2012-en 


\section{Anexos}

\section{CIMEIRA UNIÃO EUROPEIA - AMÉRICA LATINA E CARAÍBAS INTRODUÇÃO}

A primeira Cimeira entre os Chefes de Estado e de Governo da América Latina e Caraíbas e da União Europeia, com a participação do Presidente da Comissão Europeia, realizou-se na cidade do Rio de Janeiro, Brasil, em 28 e 29 de Junho de 1999, sob a co-Presidência do Presidente da República Federativa do Brasil, do Presidente dos Estados Unidos do México e do Chanceler da República Federal da Alemanha na sua qualidade de Presidente do Conselho da União Europeia. Com base nesta primeira Cimeira e na realização das suas decisões, poderá ser oportunamente organizada uma segunda Cimeira .

Esta Cimeira histórica responde a uma vontade política de reforçar as já excelentes relações bi-regionais baseadas em valores partilhados, herdados de uma História comum. Esta Cimeira tem por objectivo reforçar os laços de compreensão política, económica e cultural entre as duas regiões, a fím de desenvolver uma parceria estratégica.

A reunião dos Ministros dos Negócios Estrangeiros realizada no início da Cimeira reforçou também esta frutífera cooperação pelo substancial contributo que deu ao diálogo bi-regional.

Para fazer avançar este processo, os Chefes de Estado e de Governo decidiram implementar os compromissos expressos na presente declaração através das "Prioridades Conjuntas de Acção" anexas, o que será concretizado por intermédio das instâncias bem implantadas de diálogo político e cooperação e de outros esforços a nível bi-regional.

Como resultado das deliberações efectuadas na Cimeira, os Chefes de Estado e de Governo da América Latina e Caraíbas e da União Europeia decidiram adoptar o seguinte texto:

\section{DECLARAÇÃO DO RIO DE JANEIRO}

1. Nós, Chefes de Estado e de Governo da União Europeia, da América Latina e das Caraíbas, decidimos promover e desenvolver as nossas relações no sentido de uma parceria estratégia bi-regional, baseada na profunda herança cultural que nos une, e na riqueza e diversidade das nossas expressões culturais respectivas. Estas conferem-nos fortes e múltiplas identidades, bem como a vontade de criar um enquadramento internacional que nos permita elevar o nível de bem-estar das nossas sociedades e aplicar o princípio do desenvolvimento sustentável, tirando partido das oportunidades oferecidas por um mundo 
cada vez mais globalizado, num espírito de igualdade, respeito, aliança e cooperação entre as nossas regiões.

2. A parceria estratégica reúne dois importantes actores na actual cena internacional. A América Latina e as Caraíbas estão a caminho de ser uma das regiões mais florescentes no século XXI, devido aos progressos significativos registados nos últimos anos nas esferas política e económica e social. Assim, esta região está determinada a perseverar no avanço dos processos democráticos e da igualdade social, nos esforços de modernização, liberalização do comércio e nas reformas estruturais com ampla base de apoio. A União Europeia, por sua parte, progrediu no sentido de uma integração histórica com múltiplas implicações a nível mundial, em matéria política, económica, social, financeira e comercial, o que tem permitido melhorias constantes dos padrões de vida das suas sociedades.

3. Esta parceria estratégica baseia-se no pleno respeito do direito internacional, constituindo os objectivos e princípios consignados na Carta das Nações Unidas, a não-intervenção, o respeito da soberania, a igualdade entre os Estados e a autodeterminação dos povos, as bases das relações entre as nossas regiões.

4. Esta parceria contribuirá para a promoção de objectivos comuns, nos quais se baseia, nomeadamente o reforço da democracia representativa e participativa e da liberdade individual, o Estado de direito, a boa governação, o pluralismo, a paz e a segurança internacionais, a estabilidade política e o fomento da confiança entre as nações.

5. Sublinhamos a universalidade de todos os direitos humanos; a necessidade de contrariar a degradação do ambiente e de fomentar o desenvolvimento sustentável através da conservação e da utilização sustentáveis dos recursos naturais; a cooperação para a recuperação, preservação, difusão e expansão do património cultural; a incorporação eficiente de conhecimentos científicos e de progressos tecnológicos nos sistemas educativos a todos os níveis, e a luta contra a pobreza e contra as desigualdades sociais e baseadas no sexo.

6. Congratulamo-nos com os progressos realizados em matéria de integração na Europa e na América Latina e Caraíbas nos domínios político e económico, segundo o princípio de um regionalismo aberto.

7. Neste processo, tencionamos criar novas oportunidades e dar igual atenção às três seguintes dimensões estratégicas: um diálogo político frutífero que respeite o Direito internacional; sólidas relações económicas e financeiras, baseadas numa liberalização abrangente e equilibrada do comércio e dos fluxos de capitais, e uma cooperação dinâmica e criativa nos domínios educativo, científico, tecnológico, cultural, humano e social.

8. As prioridades de acção adoptadas pela Cimeira serão promovidas e implementadas por meio dos actuais debates ministeriais 
entre a União Europeia e os países e grupos da América Latina, bem como entre a União Europeia e os países das Caraíbas, no âmbito da Convenção de Lomé. Esses debates manterão o seu formato e periodicidade actuais. Poderão também ser realizadas reuniões ministeriais sobre certas matérias de interesse comum, como educação, investigação e ciência.

9. Decidimos também criar um Grupo Bi-Regional que funcionará a nível de Altos Funcionários. Esse grupo efectuará reuniões regulares, acompanhará e estimulará a obtenção das prioridades de acção, de um ponto de vista político e com o objectivo de contribuir, a partir dos mecanismos existentes, para um diálogo global com vista a reforçar a parceria estratégica bi-regional nas suas dimensões política, económica, social, ambiental, educativa, cultural, técnica e científica.

Neste contexto, comprometemo-nos a:

\section{Nodomíniopolítico:}

10. Reforçar os diálogos institucionais existentes entre ambas as regiões e promover a comunicação directa entre governos em matérias de integração regional, em especial na sua dimensão política, bem como a cooperação internacional baseada numa troca de experiências e informações.

11. Preservar a democracia e o pleno e total funcionamento das instituições democráticas, o pluralismo e o Estado de direito, garantindo a realização de processos eleitorais livres, justos e abertos baseados no sufrágio universal, enquanto elementos fundamentais do desenvolvimento económico e social e do reforço da paz e da estabilidade.

12 Promover e salvaguardar todos os direitos humanos e liberdades fundamentais, incluindo o direito ao desenvolvimento, tendo em conta o seu carácter universal, interdependente e indivisível, reconhecendo que a sua promoção e salvaguarda são da responsabilidade dos Estados e de todos os seus cidadãos; sublinhamos que a comunidade internacional tem um interesse legítimo nesta tarefa, nos termos da Carta das Nações Unidas, que destaca a aplicação prática dos instrumentos e normas universais e regionais sobre direitos humanos.

13. Intensificar a educação para a paz e rejeitar todas as formas de intolerância, incluindo o racismo e a xenofobia, em benefício da segurança internacional e regional e do desenvolvimento nacional, bem como promover e salvaguardar os direitos dos grupos sociais mais vulneráveis, em especial as crianças, os jovens, as pessoas deficientes e deslocadas e os trabalhadores migrantes e suas famílias.

14. Defender os princípios de um sistema judiciário independente e imparcial, promover, aplicar e manter o direito internacional e o direito humanitário internacional. Reconhecer a importância do desenvolvimento progressivo das normas referentes à responsabilidade penal do indivíduo que comete crimes de repercussão internacional. 
Assim, registamos com interesse o Estatuto Constitutivo do Tribunal Penal Internacional.

15. Reafirmar a igualdade total entre os sexos, como parte inalienável, integrante e indivisível de todos os direitos humanos e liberdades fundamentais, comprometendo-nos assim a incorporar uma perspectiva de igualdade entre os sexos nas políticas conduzidas pelos nossos governos.

16. Promover e salvaguardar os direitos das populações indígenas, nomeadamente o seu direito a participarem em pé de igualdade e a desfrutarem das oportunidades e benefícios do desenvolvimento político, económico e social, respeitando plenamente as suas identidades, culturas e tradições.

17. Intensificar os esforços para preencher as necessidades das gerações actuais e futuras, através da adopção e implementação de estratégias de desenvolvimento sustentável, que tornem compatíveis o crescimento económico, a protecção do ambiente e o progresso social.

18. Dar prioridade a vencer a pobreza, a marginalização e a exclusão social, no âmbito da promoção do desenvolvimento sustentável, alterar os padrões de produção e consumo, promover a conservação da diversidade biológica e do ecossistema mundial, bem como a utilização sustentável dos recursos naturais, e prevenir e contrariar a degradação ambiental, em especial a destruição das florestas e a erosão dos solos, bem como o empobrecimento da camada de ozono e o crescente efeito de estufa, que ameaçam o clima mundial.

19. Desenvolver esforços aos níveis nacional e regional nestes domínios, combinados com a cooperação internacional, a fim de promover o direito dos indivíduos a uma melhor qualidade de vida e integrar o conjunto da população nos processos de desenvolvimento económico e social.

20. Reconhecer que a maioria dos países carece de recursos internos para pôr em prática o leque de acções internacionalmente proposto para promover o desenvolvimento sustentável. Por isso mesmo, sublinhamos a necessidade de promover níveis adequados de investimento e de transferência de tecnologias.

21. Sublinhar a importância da contribuição de novos intervenientes, parceiros e recursos da sociedade civil, com o objectivo de consolidar a democracia e o desenvolvimento económico, e de aprofundar o respeito dos direitos humanos. A cooperação internacional, envolvendo recursos públicos, requer um diálogo do qual participem os Governos e a sociedade civil. Os parceiros na cooperação para o desenvolvimento acatarão as leis dos países envolvidos, bem como a transparência e a imputabilidade. Incentivaremos o intercâmbio e a cooperação da sociedade civil entre a América Latina, as Caraíbas e a UE.

22. Trabalhar em conjunto para enfrentar as ameaças à paz e segurança internacionais e intensificar esforços para prosseguir o 
processo de desarmamento sob controlo internacional estrito e eficaz, com destaque para a eliminação das armas de destruição maciça, nomeadamente armas nucleares, químicas e biológicas. No âmbito do calendário do desarmamento, consideramos que, após a entrada em vigor da Convenção sobre as Armas Químicas, um dos principais objectivos é a conclusão e adopção da Protocolo de Verificação da Convenção sobre as Armas Biológicas, tendo em vista a erradicação dessa categoria de armas de destruição maciça.

23. Atribuir especial importância a conseguir a adesão universal ao Tratado de Não Proliferação de Armas Nucleares, bem como à luta contra a acumulação excessiva e desestabilizadora de armas de pequeno calibre e armas ligeiras, e a sua disseminação incontrolada, e apelar a todos os Estados para que reúnam esforços no sentido de eliminar totalmente as minas terrestres antipessoal.

24. Combater o problema mundial da droga, segundo o princípio da responsabilidade comum e partilhada, com base numa abordagem global, abrangente e equilibrada, no pleno respeito dos objectivos e princípios da Carta das Nações Unidas e do Direito Internacional. O plano de acção abrangente do Panamá em matéria de drogas baseia-se nestes princípios e conferirá uma nova dimensão à cooperação neste domínio. Deveríamos utilizar os mecanismos de coordenação e cooperação entre a União Europeia e a América Latina e Caraíbas para desenvolver esta cooperação.

25. Exprimir também a nossa vontade de cumprir e dar seguimento aos acordos concluídos na XX Sessão Especial da Assembleia das Nações Unidas dedicada à acção comum para combater o problema da Toxicodependência.

26. Reunir esforços para combater todas as formas de criminalidade transnacional organizada e actividades conexas, tais como branqueamento de capitais, tráfico de mulheres, crianças e migrantes, bem como o fabrico e comércio ilegais de armas de fogo, munições e outros materiais afins.

27. Reforçar as acções individuais e conjuntas contra o terrorismo em todas as suas formas e manifestações, dado que estas últimas minam a paz, o Estado de direito e a democracia.

28. Reforçar acções individuais e conjuntas e aumentar a colaboração entre os nossos governos na luta contra a corrupção em todas as suas formas, tendo em conta os importantes instrumentos recentemente adoptados em ambas as regiões, dado que este grave problema mina a legitimidade e o funcionamento das instituições e representa uma ameaça grave para a democracia, a sociedade, o Estado de direito e o desenvolvimento.

29. Desenvolver esforços conjuntos para aumentar o diálogo, a cooperação internacional e o intercâmbio de conhecimentos na prevenção de catástrofes naturais, aproveitando ao mesmo tempo a experiência adquirida com a Década Internacional para a Redução das 
Catástrofes Naturais organizada pela ONU. Além disso, as iniciativas neste domínio devem considerar as relações entre a ajuda de emergência imediata e a recuperação e reconstrução, respeitando ao mesmo tempo critérios de desenvolvimento sustentável a longo prazo.

30. Neste contexto, reconhecer os esforços empreendidos pelos Governos e pelo povo da América Central para a reconstrução e transformação dos seus países após a tragédia do furacão "Mitch". Conferimos também grande significado à cooperação internacional para a assistência e reconstrução da América Central, em especial os contributos da América Latina e dos países das Caraíbas, e à implementação do plano da União Europeia para a reconstrução da América Central, bem como dos esforços dos Estados-Membros da União Europeia, que se elevam, na totalidade, a mais de mil milhões de euros.

31. Reforçar as instituições multilaterais, em especial como instâncias de resolução de conflitos internacionais e promoção do desenvolvimento. Neste contexto, apoiamos conjuntamente a intensificação de relações multilaterais, incluindo os progressos registados no processo de reformas do sistema das Nações Unidas, na procura de um novo equilíbrio entre os seus órgãos principais, de forma a melhorar a sua eficácia.

\section{Nodomínioeconómico:}

32. Reforçar a cooperação económica internacional, promover uma liberalização do comércio abrangente e reciprocamente benéfica, tendo em vista evitar as consequências desestabilizadoras da volatilidade dos fluxos financeiros. Serão tidas em conta, neste contexto, as assimetrias de desenvolvimento.

33. Reafirmar a nossa convicção de que a integração regional desempenha um importante papel na promoção do crescimento, na liberalização do comércio,

no desenvolvimento económico e social, na estabilidade democrática e numa inclusão mais simétrica no processo de globalização. Sublinhamos em especial a nossa vontade de reforçar o sistema de comércio multilateral e o regionalismo aberto, bem como de intensificar as relações económicas entre as nossas regiões.

34. Reconhecer a nossa responsabilidade partilhada por uma contribuição eficaz e orientada para a obtenção de resultados concretos em todos estes aspectos.

Através da nossa nova parceria inter-regional, estamos decididos, em especial, a:

35. Congregar os nossos esforços para garantir que os compromissos assumidos no Uruguay Round entrem em vigor de forma completa e a tempo e sejam efectivamente aplicados.

36. Sublinhar a importância da Organização Mundial do Comércio como principal instância de promoção da liberalização do comércio e de 
fixação de regras e orientações básicas para o sistema internacional de comércio.

37. Propor conjuntamente, na próxima sessão ministerial da OMC, o lançamento de uma nova ronda de negociações abrangentes no domínio do comércio, sem excluir nenhum domínio, tendo em vista a redução de barreiras pautais e não pautais ao comércio de bens e serviços.

38. Reiterar a nossa firme rejeição de todas as medidas de carácter unilateral e de efeito extraterritorial que sejam contrários ao Direito Internacional e às regras de livre comércio usualmente aceites. Concordamos que esse tipo de práticas representa séria ameaça ao multilateralismo.

39. Promover um maior desenvolvimento e diversificação do comércio, tendo em conta as actuais e futuras negociações multilaterais e bilaterais para a liberalização do comércio, tal como no caso da União Europeia com o México, o Mercosul e o Chile assim como a futura evolução das nossas regiões.

40. Promover o diálogo neste domínio e incentivar a criação de um clima favorável aos fluxos financeiros e ao investimento produtivo entre a América Latina, as Caraíbas e a União Europeia, em especial encorajando a criação de empresas mistas, através do Banco Europeu de Investimento (BEI), bem como outros instrumentos de cooperação, tais como os investimentos bilaterais e os acordos de protecção recíproca.

41. Dar especial atenção e apoio a países com economias mais pequenas, nomeadamente através de incentivos ao investimento produtivo. Deveríamos analisar e implementar condições e medidas financeiras favoráveis, que permitam tratar justa e adequadamente, nas instâncias competentes e específicas, os países pobres altamente endividados. Nesse sentido, congratulamo-nos com o acordo entre os Chefes de Estado e de Governo do G7 sobre um novo pacote de iniciativas de redução da dívida dos países pobres altamente endividados.

42. Promover um maior contacto entre agentes económicos e incentivar um diálogo alargado entre os membros da comunidade empresarial e das instâncias sectoriais de ambas as partes, que são de grande importância para as

relações entre as nossas regiões, e em especial para o desenvolvimento económico e social.

43. Promover a cooperação científica e tecnológica tendo em vista reforçar as capacidades nacionais nestes domínios e contribuir para os esforços de resolução dos problemas globais; incentivar o investimento e as parcerias empresariais que impliquem transferências de tecnologias e de conhecimentos específicos do saber fazer.

44. Apoiar o reforço e a aplicação dos direitos de propriedade intelectual em todos os domínios como condição importante para a intensificação dos 
fluxos comerciais e de investimentos.

45. Promover, no contexto da globalização e do avanço da sociedade da informação, o comércio de serviços, bem como apoiar novas formas de cooperação neste domínio como importantes factores de estreitamento dos laços económicos entre ambas as regiões.

46. Incentivar a transferência de tecnologias tendo em vista uma melhoria dos processos e padrões dos laços económicos entre a União Europeia e a América Latina e Caraíbas nos domínios da produção de bens, do comércio externo, das infra-estruturas portuárias e das telecomunicações e transportes.

47. Promover um clima favorável às pequenas e médias empresas - que desempenham um importante papel no contexto do desenvolvimento de economias de mercado estáveis -, ao reforço das trocas económicas e à criação de "joint ventures" entre as duas regiões.

48. Salientar o papel decisivo que a eficiência das infra-estruturas, incluindo as infra-estruturas de transportes, e dos procedimentos administrativos assume para a liberalização do comércio e a intensificação da cooperação económica.

49. Reforçar a nossa parceria na cooperação para o desenvolvimento, que oferece uma importante oportunidade para pôr em prática, com proveitos recíprocos, os valores e ideais comuns.

50. Participar activamente, dada a gravidade e recorrência das crises financeiras e o severo impacto das mesmas aos níveis nacional e internacional, na concepção de uma nova arquitectura financeira internacional, que permita a ambas as regiões desfrutar de todas as vantagens da integração dos mercados de capitais e reduzir os riscos decorrentes da sua volatilidade.

51. Continuar a reforçar os sistemas financeiros dos nossos países e a elaborar regulamentações e mecanismos de controlo, a fim de aplicar as melhores normas e práticas internacionais, o que contribuirá para estabelecer um sistema económico e financeiro dinâmico e estável a nível internacional. Esse sistema permitirá prevenir futuras crises ou, no caso de estas se verificarem, permitirá identificá-las precocemente e resolvê-las de forma rápida e eficaz, por forma a impedir a sua generalização.

52. Reconhecer que a introdução do euro contribui de facto para reforçar os nossos laços económicos e financeiros bi-regionais, bem como o sistema financeiro e monetário internacional, conferindo-lhe estabilidade e dinamismo. 
53. Promover a participação activa dos nossos governos nas consultas realizadas nas Nações Unidas sobre as tendências actuais dos fluxos financeiros a nível mundial. Conjugar esforços para operar uma reforma do sistema financeiro internacional, bem como para definir e implementar um programa destinado a garantir a estabilidade financeira internacional, que inclua o acompanhamento do sistema monetário mundial com o objectivo de prevenir as crises.

\section{Nosdomínioscultural,educativo,científico,tecnológico,socialehumano:}

54. Reiterar o nosso empenho no estabelecimento de uma parceria sólida entre a União Europeia e a América Latina e as Caraíbas nos domínios educativo, cultural e humano, baseada em valores partilhados e no reconhecimento da importância que a educação assume para atingir a igualdade social e obter progressos científicos e tecnológicos. Comprometemo-nos igualmente a basear as nossas relações em princípios de igualdade e respeito pelo pluralismo e pela diversidade, sem distinção de raça, religião ou sexo, preceitos estes que constituem os meios ideais para criar uma sociedade aberta, tolerante e abrangente, em que o direito individual à liberdade e ao respeito mútuo seja reforçado pelo acesso equitativo à capacidade de produção, à saúde, à educação e à protecção civil.

55. Concordar que não há melhor investimento do que o desenvolvimento dos recursos humanos, que constitui simultaneamente um penhor de justiça social e uma exigência de crescimento económico a longo prazo.

56. Disponibilizar mais recursos para responder a necessidades sociais justas e urgentes e para melhorar o âmbito e a qualidade dos nossos programas sociais.

57. Tencionar partilhar experiências entre as nossas duas regiões sobre as diferentes políticas sociais que aplicamos, de modo a reforçar a cooperação neste domínio, em especial nas áreas da saúde, da alimentação, da educação e do emprego.

58. Sublinhar ainda que é importante criar nos nossos países postos de trabalho em número suficiente, produtivos e bem remunerados. Para o efeito, são essenciais a educação e a formação profissional dos trabalhadores de todas as idades.

Acordámos, nomeadamente, em:

59. Promover a recuperação, a preservação e um melhor conhecimento das nossas vastas heranças culturais, incluindo o património, e da nossa diversidade enquanto laço fundamental entre a América Latina e as Caraíbas, por um lado, e a União Europeia, por outro, permitindo a instituição de relações mais estreitas e duradouras entre os nossos povos e promovendo a criatividade cultural como um diálogo para a paz e a tolerância. 
60. Promover, tanto nas regiões como nas instâncias multilaterais, acções destinadas a fomentar a diversidade cultural e o pluralismo no mundo.

61. Incentivar os intercâmbios inter-regionais entre agentes educativos e culturais como um dos meios mais eficazes de promoção da compreensão recíproca, do conhecimento e da produção cultural. A promoção de contactos estreitos entre artistas e organizações em todos os sectores culturais fomentará o respeito da diversidade cultural e linguística, garantindo a dignidade humana e o desenvolvimento social.

62. Incentivar o reforço da cooperação e do intercâmbio entre indústrias culturais e no sector do audiovisual, como pilares fundamentais da cooperação cultural e económica, indo ao encontro de um interesse acrescido pelas produções de alta qualidade.

63. Considerar o reforço da cooperação no domínio da educação como um desafio específico, destacando em especial o ensino básico, a formação profissional e a cooperação entre instituições de ensino superior, nomeadamente universidades, e o ensino à distância, e ter em conta as necessidades específicas das nossas sociedades. Neste contexto, recordamos o êxito dos programas de cooperação já existentes.

64. Promover o acesso universal à educação e à formação profissional, como factores determinantes para reduzir as desigualdades sociais e a pobreza, e para conseguir empregos mais bem remunerados, assegurando um ensino básico pleno a todas as pessoas em idade escolar e o direito dos povos a conservar a sua identidade cultural e linguística. Sublinhamos o direito em si à educação, assente na responsabilidade nacional específica de cada país de dar a todos os cidadãos uma educação adequada.

65. Promover a investigação científica e o desenvolvimento tecnológico, como elementos fundamentais das nossas relações e como condição essencial para que os países se insiram com êxito num mundo globalizado, que exige progressos do conhecimento científico, o seu domínio e a adaptação a uma tecnologia em constante evolução.

66. Incentivar a inovação e a transferência de tecnologias, a fim de estabelecer uma maior ligação a nível científico e económico entre as duas regiões, nomeadamente nos domínios da produção de bens e de serviços, do comércio externo, das infra-estruturas, das telecomunicações e dos transportes.

67. Saudar os vários acontecimentos promovidos antes e durante a Cimeira em que participaram diferentes sectores da sociedade civil.

68. O nosso diálogo actual e a nossa cooperação nas instâncias interregionais e internacionais pautam-se por estes compromissos solenes, que, ao mesmo tempo, contribuem para firmar com êxito a nossa parceria estratégica.

69. Os participantes exprimiram a sua profunda gratidão ao povo e ao 
Governo do Brasil pela cortesia e pelo apoio dispensado, que contribuíram para o êxito dos trabalhos da Cimeira.

\title{
CIMEIRA UNIÃO EUROPEIA- AMÉRICA LATINA E CARAÍBAS
}

\author{
Madrid, 17 de Maio de 2002
}

\section{DECLARAÇÃO POLÍTICA COMPROMISSO DE MADRI}

Nós, os Chefes de Estado e de Governo da União Europeia, da América Latina e das Caraíbas, reunidos em Madrid, comprometemo-nos a impulsionar a nossa parceria estratégica bi-regional, baseada na Declaração e no Plano de Acção aprovados na Primeira Cimeira, realizada no Rio de Janeiro, em Junho de 1999. A nossa história e cultura, bem como os valores e os princípios que nos são comuns, constituem a base desta relação privilegiada e da abordagem comum das principais questões internacionais.

Juntos, devemos enfrentar os grandes desafios e aproveitar as oportunidades do século XXI. Com um espírito de respeito mútuo, igualdade e solidariedade, reforçaremos as nossas instituições democráticas e estimularemos os processos de modernização das nossas sociedades, tendo em conta a importância do desenvolvimento sustentável, da erradicação da pobreza, da diversidade cultural, da justiça e da equidade social. Acreditamos que o estímulo dos nossos processos de integração e o aumento do comércio e do investimento constituem meios importantes para um melhor acesso aos benefícios da globalização.

Neste sentido, a fim de desenvolver uma sólida parceria estratégica bi-regional e na sequência dos nossos debates de hoje, assumimos os seguintes compromissos:

\section{No domínio político}

1. Reforçar o sistema multilateral com base nos objectivos e nos princípios da Carta das Nações Unidas e do direito internacional.

2. Fortalecer as nossas instituições democráticas e o Estado de Direito e reforçar os sistemas judiciais, garantindo a igualdade de tratamento perante a lei e promovendo e protegendo os direitos humanos.

3. Saudar o eminente estabelecimento e eficaz funcionamento do Tribunal Penal Internacional e promover a adesão universal ao Estatuto de Roma.

3. Combater o terrorismo, em todas as suas formas e manifestações, o qual constitui uma ameaça aos nossos sistemas democráticos, às nossas liberdades e ao nosso desenvolvimento, bem como à paz e à segurança 
internacionais, de acordo com a Carta da ONU e no pleno respeito pelo direito internacional, incluindo os direitos humanos e as normas do direito humanitário. Comprometemo-nos a reforçar os nossos mecanismos de cooperação política, judiciária e operacional e a promover a celebração de todas as convenções internacionais sobre terrorismo, assim como a adesão às mesmas, e a implementação das resoluções da ONU nessa matéria.

5. Reforçar a nossa cooperação na luta contra o flagelo das drogas ilícitas e crimes conexos, da corrupção e da criminalidade organizada, melhorando os mecanismos de coordenação, combatendo as fontes de financiamento da produção e do tráfico de drogas e bem assim impedindo o seu uso para o financiamento do terrorismo e das actividades criminosas em todo o mundo.

6. Erradicar o racismo, a discriminação racial, a xenofobia e a intolerância que lhes está associada e, neste contexto, trabalhar conjuntamente na implementação dos compromissos assumidos na Declaração de Durban e no Programa de Acção adoptado na Conferência Mundial de 2001.

7. Promover a igualdade entre os homens e as mulheres e o reforço do papel das mulheres, não só como um princípio de política geral, mas também como meio eficaz de combater a pobreza e alcançar um desenvolvimento sustentável e equitativo.

8. Promover e proteger o bem-estar de todas as crianças em conformidade com o documento "Um mundo adequado às crianças" aprovado na sessão extraordinária das Nações Unidas sobre a Criança (Nova Iorque, 8-10 de Maio de 2002).

9. Reforçar o diálogo bi-regional nos fóruns internacionais e as consultas no âmbito do sistema da ONU, bem como nas grandes Conferências das Nações Unidas consagradas às principais questões da agenda internacional.

10. Repudiamos as repetidas violações dos direitos humanos e do direito humanitário internacional por grupos armados na Colômbia, e condenamos os atentados e sequestros terroristas, incluindo os perpetrados recentemente. Apoiamos ainda uma solução negociada para o conflito na Colômbia.

11. Incentivamos todos os esforços desenvolvidos pela Guatemala e Belize na procura de uma solução pacífica, honrosa e definitiva do seu conflito territorial através do processo de mediação patrocinado pela OEA.

12. Exortamos todas as partes implicadas na crise política no Haiti a intensificarem esforços para fortalecer a democracia e criar condições susceptíveis de conduzir a um rápido e completo reatamento da cooperação entre o Haiti e a comunidade internacional, tendo por objectivo pôr fim à deterioração dos padrões de vida do povo haitiano.

\section{No domínioeconómico}

13. Redobrar esforços no âmbito da nossa cooperação bi-regional e promover o crescimento económico, a fim de combater a pobreza 
através, inter alia, do fortalecimento das nossas instituições democráticas, da estabilidade macroeconómica, da redução do fosso tecnológico, de um maior acesso à educação, aos cuidados de saúde e à protecção social, assim como da melhor qualidade dos mesmos. Neste contexto, cooperaremos em domínios como o aumento da eficácia das instituições públicas, o aprofundamento dos processos de integração regional, o estimulo ao dinamismo das pequenas e médias empresas; e o fomento do desenvolvimento de infra-estruturas. Encorajamos a Comissão Europeia, o Banco Europeu de Investimento e o Banco Interamericano de Desenvolvimento a apresentarem iniciativas e manterem informados os mecanismos de cooperação bi-regional.

14. Enfrentar os desafios que se colocam às pequenas economias, em especial dos pequenos Estados insulares em desenvolvimento.

15. Promover os fluxos comerciais e de investimento que favoreçam um crescimento económico sustentável e a distribuição equitativa dos seus benefícios, mediante um contexto jurídico e empresarial mais aberto, seguro, não discriminatório e transparente.

16. Manifestamos a nossa satisfação pela conclusão das negociações de um Acordo de Associação entre a União Europeia e o Chile. Este novo acordo vem somar-se ao primeiro Acordo de Associação entre as nossas duas regiões, o qual proporcionou um claro impulso às relações políticas, comerciais, de investimento e de cooperação entre a União Europeia e o México.

Salientamos a importância de que para nós se revestem as negociações em curso entre a UE e o MERCOSUL e registamos, neste contexto, que os capítulos consagrados aos domínios político, institucional e da cooperação se encontram virtualmente concluídos. Congratulamo--nos com os progressos até agora alcançados no capítulo comercial e com a aprovação do pacote de medidas de facilitação de negócios e estamos confiantes de que continuaremos a registar um progresso substancial por forma a concluir com êxito o processo de negociação logo que possível.

17. Saudamos o facto de os Estados das Caraíbas, associando-se aos demais Estados membros do Grupo dos Estados de África, das Caraíbas e do Pacífico, terem decidido lançar formalmente, em Setembro de 2002, negociações com a União Europeia para a celebração de um Acordo de Parceria Económica no quadro do Acordo de Cotonou. Congratulamo-nos com as novas iniciativas para a negociação de um acordos políticos e de cooperação entre a UE e a América Central e entre a UE e a Comunidade Andina, bem como com a decisão de reforçar a cooperação comercial, os investimentos e as relações económicas. A concretização dos objectivos desses acordos e o reforço da cooperação deverão criar condições que, com base nos resultados do programa de trabalho de Doha que nos comprometemos a concluir até ao final de 2004, permitirão negociar um acordos de associação exequíveis e mutuamente benéficos, incluindo uma ZCL, entre a UE e a América Central e entre a UE e a Comunidade Andina.

18. Acolhemos com satisfação e apoiamos os presentes esforços das autoridades argentinas para ultimar um programa económico sólido e abrangente que permita levar a bom termo negociações com o Fundo Monetário Internacional e outros organismos financeiros. As autoridades 
argentinas contam com o nosso apoio para atingirem esse objectivo, por forma a superar a situação em que a nação se encontra.

19. Trabalhar com celeridade no Programa de trabalho de Doha, a fim de alcançar uma maior liberalização do comércio e a clarificação, melhoria e reforço das regras multilaterais quando aplicáveis, bem como de garantir que a V Conferência Ministerial, a realizar no México, prepare o caminho para que as negociações previstas na Declaração de Doha sejam concluídas com êxito até ao final de 2004. Sublinhamos, neste contexto, a importância das disposições sobre desenvolvimento constantes da Declaração de Doha, incluindo a implementação do programa de trabalho sobre o tratamento especial e diferenciado, a fim de apoiar a integração dos países em desenvolvimento na economia mundial.

20. Trabalhar em conjunto no sentido de contribuir para o êxito da Cimeira Mundial sobre o Desenvolvimento Sustentável, a realizar em Joanesburgo em Agosto de 2002. Esperamos um resultado que se traduza em acções concretas, que envolva tanto compromissos globais em termos de desenvolvimento sustentável, como parcerias entre os governos, a sociedade civil e o sector privado e que reafirme os compromissos assumidos na Conferência do Rio de 1992 e a implementação da Agenda 21.

21. Colaborar na protecção do meio-ambiente, com especial ênfase na mudança de padrões insustentáveis de produção e consumo, na preservação da biodiversidade e do ecossistema mundial e na utilização sustentável dos recursos naturais. Actuaremos no sentido de atingir, o mais cedo possível, a ratificação universal e a entrada em vigor do Protocolo de Quioto.

22. Actuar de acordo com os compromissos acordados na Conferência de Monterrey sobre o Financiamento do Desenvolvimento, em especial mobilizando os recursos internacionais e internos, criando contextos nacionais e internacionais que permitam a redução da pobreza, intensificando substancialmente a cooperação para o desenvolvimento e pondo em prática medidas de alívio destinadas a lidar com o problema da dívida externa insustentável dos países em desenvolvimento. Instar à plena implementação do consenso de Monterrey.

23. Melhorar o funcionamento do sistema financeiro internacional, tendo em conta as preocupações dos países em desenvolvimento, e participar activamente nos esforços actualmente desenvolvidos a nível internacional no sentido de proceder à reforma do sistema financeiro internacional.

24. Promover a rápida e efectiva implementação da iniciativa reforçada "Paí ses Pobres Altamente Endividados", assinalando que alguns países em desenvolvimento são também credores.

25. Saudar a introdução do euro, cujo contributo para a maior transparência das nossas relações económicas é plenamente reconhecido; reconhecer o contributo potencial do euro para estimular o crescimento do comércio e do investimento entre as nossas regiões. 
26. Rejeitar firmemente todas as medidas de carácter unilateral com efeitos extraterritoriais que sejam contrárias ao Direito internacional e às regras do comércio livre por todos aceites. Concordámos que este tipo de prática representa uma séria ameaça ao multilateralismo.

27. Trabalhar em conjunto para desenvolver a Sociedade da Informação, através de um maior acesso às tecnologias da informação e comunicação e aproveitar as oportunidades oferecidas por tais tecnologias em domínios prioritários como o da sua aplicação nos serviços públicos.

\section{Cooperacãonosdomínioscultural,educativo,científico,tecnológico,sociale humano}

28. Preservar as nossas capacidades de desenvolver, fomentar e respeitar a diversidade cultural.

29. Criar mais oportunidades nas nossas regiões nas áreas da educação, cultura e acesso ao conhecimento, fundamentais para o sucesso no século XXI. Incentivamos o fortalecimento do actual Programa Alfa para a cooperação institucional no domínio da educação superior. Saudamos igualmente o Programa @LIS para o desenvolvimento da Sociedade da Informação, bem como um novo programa similar interligado para as Caraíbas, e o novo programa de bolsas de estudo da UE para a América Latina.

30. Recomendar o desenvolvimento, aprovação e promoção do Plano de Acção 2002-2004 para a criação de um Espaço Comum União EuropeiaAmérica Latina e Caraíbas para a Educação Superior.

31. Efectuar uma análise integrada das diferentes questões referentes às migrações entre as nossas duas regiões, que tem sido e continua a ser extremamente benéfica para ambas as partes, no sentido de implementar soluções que garantam o pleno respeito pelos direitos fundamentais dos trabalhadores migrantes e das suas famílias em conformidade com o Direito Internacional e as legislações nacionais.

32. Combater o HIV/SIDA através de programas de prevenção, tratamento e apoio, em especial nos países mais afectados, tendo presente o direito a níveis de cuidados de saúde adequados e a necessidade de promover um maior acesso aos medicamentos.

33. Cooperar na promoção da capacidade dos países em antecipar e reagir a catástrofes naturais e na atenuação das suas consequências. Congratulamo-nos com os resultados e as propostas satisfatórias das reuniões ministeriais UE-ALC sobre Ensino Superior (Paris, 3-4 de Novembro de 2000), Ciência e Tecnologia (Brasília, 21--22 de Março de 2002), Sociedade da Informação (Sevilha, 26-27 de Abril de 2002) e Protecção Social (Valência, 14-15 de Maio de 2002), que representam um contributo significativo para a construção da parceria estratégica bi-regional. 
Aprovamos o Relatório de Avaliação e adoptamos o documento sobre Valores e Posições Comuns. Mandatamos os mecanismos bi-regionais para que continuem a acompanhar o seguimento das

Cimeiras, com o apoio, quando oportuno, das instituições financeiras internacionais envolvidas em programas de cooperação bi-regional. Nesse contexto, será realizada uma reunião de Altos Funcionários durante o segundo semestre de 2002 para analisar o seguimento da Cimeira de Madrid. A reunião deverá debater, inter alia, os objectivos e resultados esperados da reunião bi-regional sobre cooperação, a realizar na Costa Rica até ao final de 2002.

Agradecemos e aceitamos o convite para a realização da Terceira Cimeira UE-ALC, no México, em 2004.

Exprimimos uma profunda gratidão ao Governo e ao povo da Espanha por toda a cortesia e apoio que permitiram concluir com êxito a Cimeira de Madri 


\section{DECLARAÇÃO DE GUADALAJARA}

do

1. Nós, os Chefes de Estado e de Governo da América Latina e

Caribe e da União Européia, reunidos em Guadalajara, México, em 28 e 29 de maio de 2004, reiteramos nosso compromisso com a consolidação da parceria estratégica bi-regional aprovada no Rio de Janeiro em 1999.

2. Damos as boas-vindas aos Chefes de Estado e de Governo dos dez novos Estados Membros da União Européia, importante contribuição ao fortalecimento de nossa parceria, que agora inclui mais de um quarto das nações do mundo.

3. Nossa parceria está fundada em profundos vínculos históricos e culturais, princípios compartilhados do Direito Internacional e valores dos nossos povos. Enfatizamos nosso respeito por e a plena observância do Direito Internacional e pelos propósitos e princípios estabelecidos na Carta das Nações Unidas, inclusive os princípios de não intervenção e autodeterminação, respeito à soberania, à integridade territorial e à igualdade entre os estados, os quais, junto com o respeito aos Direitos Humanos, a promoção da democracia e a cooperação para o desenvolvimento econômico e social, são as bases das relações entre nossas regiões. Esforçar-nos-emos por fortalecer o respeito a estes princípios e por enfrentar os desafios e aproveitar as oportunidades de um mundo cada vez mais globalizado, num espírito de igualdade, respeito, associação e cooperação.

4. Acreditamos que a democracia, o Estado de Direito e o desenvolvimento econômico e social são fundamentais para a paz e a estabilidade em nossas regiões. Continuaremos a fortalecer a democracia e a aperfeiçoar e consolidar as instituições democráticas em todos nossos países.

5. Reiteramos nosso compromisso com a promoção e a proteção de todos os direitos humanos - civis, políticos, econômicos, sociais e culturais, inclusive o direito ao desenvolvimento - e das liberdades fundamentais; reafirmamos nossa convicção de que os direitos humanos são universais, interdependentes e indivisíveis. Reconhecemos que a promoção e a proteção desses direitos, inerentes a todos os seres humanos, são de responsabilidade dos Estados.

6. Apoiamos plenamente o fortalecimento do sistema internacional para a promoção e proteção dos direitos humanos. Estamos decididos a combater todas as ameaças ao pleno usufruto de todos os direitos humanos e a tomar as medidas necessárias para promover sociedades democráticas, participativas, eqüitativas, tolerantes e inclusivas.

7. Estamos plenamente comprometidos com o apoio coerente e efetivo aos indivíduos, organizações ou instituições, inclusive os defensores dos direitos humanos, que trabalhem em prol da promoção e proteção dos direitos humanos, em conformidade com o Direito Internacional e com a Resolução LIII/144 da Assembléia Geral das Nações Unidas sobre o Direito e o Dever dos 
Indivíduos, Grupos e Instituições de Promover e Proteger os Direitos Humanos e as Liberdades Fundamentais Universalmente Reconhecidos.

\section{Declaramos que: Multilateralismo}

8. Reiteramos que um sistema multilateral eficaz, baseado no Direito Internacional, apoiado em instituições internacionais fortes, com a Organização das Nações Unidas como centro, é essencial para alcançar a paz e a segurança internacional, o desenvolvimento sustentável e o progresso social.

9. Reafirmamos o papel central das Nações Unidas na promoção do desenvolvimento econômico e social e na erradicação da pobreza e da fome.

10. Compartilhamos uma confiança fundamental no sistema multilateral de segurança coletiva consubstanciado na Carta das Nações Unidas. Enfatizamos nosso firme apoio aos órgãos das Nações Unidas no exercício de suas plenas responsabilidades, funções e poderes, de acordo com a Carta das Nações Unidas.

11. Comprometemo-nos a cooperar nas Nações Unidas para a prevenção de conflitos, a solução pacífica de controvérsias, a gestão de crises, as operações de manutenção da paz e de consolidação da paz pósconflito, em conformidade com a Carta das Nações Unidas e os princípios do Direito Internacional.

12. Reconhecemos a necessidade de tornar mais ágil e efetivo o sistema multilateral a fim de enfrentar as ameaças e os desafios globais. Nesse sentido, comprometemo-nos com a reforma e a revitalização das Nações Unidas, inclusive do Conselho de Segurança e da Assembléia Geral.

13. Enfatizamos nosso apoio à atuação do Grupo de Trabalho Aberto estabelecido pela Assembléia Geral e à iniciativa do Secretário Geral das Nações Unidas de estabelecer um Painel de Alto Nível sobre Ameaças, Desafios e Mudança.

14. Reconhecemos que o fortalecimento das organizações regionais é um meio essencial para aperfeiçoar o multilateralismo.

15. Reafirmamos o compromisso de continuar nossos esforços para manter e melhorar o diálogo e a consulta, conforme o caso, a fim de definir posições comuns e ações conjuntas das duas regiões nos diversos órgãos e nas principais Conferências das Nações Unidas.

16. Estamos convencidos de que um enfoque multilateral da segurança oferece os melhores meios para manter a ordem internacional. Daremos prioridade à promoção de avanços concretos no desarmamento, em especial de armas nucleares, químicas e biológicas, no controle de armas e na nãoproliferação, assim como à busca da universalização, respeito e cumprimento dos acordos multilaterais na matéria, através do fortalecimento do papel das Nações Unidas. Reconhecemos como pedra angular do regime de não- 
proliferação o Tratado de Não-Proliferação das Armas Nucleares, e reiteramos nosso apoio à implementação desse instrumento em todos seus aspectos. Do mesmo modo, promoveremos a efetiva implementação do Programa de Ação das Nações Unidas para a Prevenção, o Combate e a Erradicação do Comércio Ilícito de Armas Leves e de Pequeno Porte. Apoiaremos os projetos bi-regionais para prevenir a produção e o tráfico ilegais de tais armas e promoveremos medidas para seu recolhimento e destruição.

17. Expressamos nossa mais profunda solidariedade com as vítimas do terrorismo e com suas famílias, inclusive com as que sofreram os ataques terroristas em Madri, em 11 de março de 2004. Reiteramos nossa firme condenação a todos os atos de terrorismo e a seu financiamento e nos comprometemos a, por meio da cooperação mútua, prevenir, combater, sancionar e eliminar o terrorismo em todas suas formas e manifestações, onde quer e por quem quer que o cometa, em estrita observância do Direito Internacional, e em especial ao dos direitos humanos, e do Direito Internacional Humanitário. A este respeito, declaramos nosso pleno apoio à implementação de todos os compromissos da Resolução

1373 do Conselho de Segurança das Nações Unidas e da Resolução XLIX/60 da Assembléia Geral, bem como das Convenções pertinentes das Nações Unidas.

18. Expressamos nosso pleno apoio ao Tribunal Penal Internacional como um meio eficaz de se combater a impunidade dos mais hediondos crimes que afligem a comunidade internacional. Os Estados Partes no Estatuto de Roma fazem um apelo aos países que ainda não o ratificaram ou a ele se aderiram a que o façam, conforme o caso.

19. Condenamos firmemente todas as formas de abusos, torturas e outros tratamentos cruéis, desumanos e degradantes contra pessoas, inclusive prisioneiros de guerra, onde quer que ocorram. Declaramo-nos horrorizados diante das recentes evidências de maltrato de prisioneiros nas prisões iraquianas. Tais abusos são contrários ao Direito Internacional, inclusive às Convenções de Genebra. Acolhemos com satisfação o compromisso dos Governos em questão de levar aos tribunais todos os indivíduos responsáveis por tais atos, de maltrato dos prisioneiros iraquianos, e seu compromisso de corrigir qualquer falha no respeito ao Direito Internacional Humanitário. Apelamos a todos os Governos a que façam cumprir plenamente a proibição da tortura e de outros tratamentos cruéis, desumanos e degradantes, em conformidade com a Convenção das Nações Unidas contra a Tortura e as Convenções de Genebra, e de levar aos tribunais os que violarem tais obrigações.

20. Os Estados Partes na Convenção sobre a Proibição do Uso, Produção, Armazenamento e Transferência de Minas Terrestres Antipessoal e sua Destruição cumprirão integralmente seus compromissos e promoverão sua universalização. Os Estados Partes reconhecem que a Primeira Conferência de Revisão da Convenção, a ser celebrada em Nairobi, Quênia, de 29 de novembro a 3 de dezembro de 2004, representa um marco importante para avaliar os progressos na implementação, até então, da Convenção. Condenamos o uso e a produção de minas terrestres antipessoal por parte de todos os atores não estatais. Continuaremos a unir esforços para eliminar o sofrimento causado pelas minas antipessoal e apoiaremos os 
programas para sua desativação e para reabilitação.

21. Enfatizamos a importância da assinatura, ratificação ou adesão à Convenção das Nações Unidas contra a Delinquiência Organizada Transnacional e a seus protocolos adicionais.

22. Reconhecemos o papel essencial da cooperação internacional para enfrentar o problema global do tráfico de drogas ilícitas e de suas consequiências para a saúde, assim como os crimes relacionados com sua produção e tráfico. Adotaremos um enfoque equilibrado, multilateral, abrangente e não seletivo diante deste problema, baseado nos princípios de responsabilidade comum e compartilhada, e conforme a legislação de cada país.

23. Reconhecemos a necessidade de compreender plenamente as causas deste problema a fim de reduzir o consumo e a dependência de drogas em nossas sociedades.

24. A União Européia está analisando maneiras compatíveis com a OMC para assegurar acesso, sob o esquema do Sistema Geral de Preferências, ao mercado da União Européia por parte dos países da América Latina e do Caribe particularmente afetados pela produção e tráfico ilícito de drogas.

25. Reconhecemos a especificidade do desafio enfrentado pelas sociedades do Caribe perante o tráfico e abuso de drogas ilícitas e outras atividades criminosas relacionadas. Conseqüentemente, recebemos com satisfação a aprovação pelo CARICOM de uma Estratégia Regional para a Redução da Demanda de Drogas, assim como o trabalho e as recomendações da Força Tarefa Regional sobre Crime e Segurança. Diante do reconhecimento específico, no Plano de Ação Global do Panamá, da necessidade de uma cooperação marítima mais estreita, recebemos igualmente com satisfação a conclusão de acordos regionais e bilaterais em matéria de cooperação marítima, como o Acordo Relativo à Cooperação para Suprimir o Tráfico Ilícito Marítimo e Aeronáutico de Drogas Estupefacientes e Substâncias Psicotrópicas na Região do Caribe, aberto à assinatura em São José da Costa Rica, em 10 de abril de 2003.

26. Reiteramos nosso compromisso com o fortalecimento da cooperação para enfrentar os problemas causados pelas drogas ilícitas e com o pleno aproveitamento dos esquemas existentes de diálogo e de cooperação entre as duas regiões, principalmente através do Diálogo de Alto Nível entre a União

Européia e a Comunidade Andina sobre Drogas, e do Mecanismo de Cooperação e Coordenação da UE e ALC sobre Drogas.

27. Acolhemos com satisfação e apoiamos, portanto, a Declaração de Dublim, adotada em 19 de maio de 2004, ao final da VI Reunião de Alto Nível do Mecanismo de Coordenação e Cooperação sobre Drogas entre a União Européia e a América Latina e o Caribe. Nesse sentido, esforçar-nos-emos por continuar a desenvolver esse Mecanismo como um forum onde buscar novos enfoques e intercâmbio de propostas, idéias e experiências. 
28. Acolhemos com satisfação a coordenação de nossas posições em fora internacionais, em especial na XLVII Sessão da Comissão das Nações Unidas sobre Drogas Estupefacientes, e manifestamos nosso desejo de continuar com esta experiência positiva.

29. Fazemos um apelo a todos os Estados a que assinem e ratifiquem a Convenção das Nações Unidas contra a Corrupção, a fim de assegurar sua pronta entrada em vigor. Reforçaremos a cooperação internacional nesta área, promovendo uma cultura da democracia mediante uma efetiva reforma administrativa e a transparência governamental em todos os níveis. Continuaremos a fortalecer a governabilidade e as instituições democráticas e a encorajar maior participação por parte da sociedade civil organizada e dos partidos políticos, de acordo com a legislação nacional pertinente. Fortaleceremos os mecanismos de intercâmbio de experiências em matéria judicial e de cooperação entre os Estados a fim de contribuir com a atuação eficiente do poder judiciário.

30. Tomaremos medidas para erradicar a corrupção e para promover a ética e a transparência nas atividades governamentais e do setor privado. Nesse sentido, expressamos nossa preocupação com as práticas corruptas, ilegais e fraudulentas de alguns servidores públicos e executivos de certas empresas nacionais e transnacionais que acarretam conseqüências econômicas negativas, especialmente para os países em desenvolvimento, e em particular para seus produtores e consumidores.

31. Reiteramos nosso compromisso com a Convenção Quadro das Nações Unidas sobre Mudança do Clima e exortamos os países que ainda não ratificaram o Protocolo de Quioto para que o façam sem demora. Salientamos, além das medidas de mitigação essenciais para enfrentar a mudança do clima, a importância de se atribuir prioridade às atividades e projetos relacionados com a vulnerabilidade e a adaptação à mudança do clima.

32. Reconhecemos o particular desafio que a mudança do clima mundial representa para a sustentabilidade do desenvolvimento das áreas mais afetadas, assim como seu impacto negativo nos ecossistemas frágeis. Nesse sentido, reconhecemos a especial vulnerabilidade da região do Caribe, em conseqüência da maior intensidade e freqüência de furacões e enchentes, assim como os danos por eles causados. Acolhemos com satisfação a recente criação, no âmbito do Banco do Desenvolvimento do Caribe, do Fundo de Recuperação dos Furacões.

33. Tomamos nota das sérias preocupações expressas pelo Caribe e por outros países da América Latina sobre os potenciais riscos para a segurança ambiental, maritima e humana incorridos no transporte através do Mar do Caribe de resíduos nucleares e radioativos não processados. Uniremos esforços para assegurar que tais potenciais riscos sejam geridos adequadamente e apoiaremos a intensificação da cooperação nesta matéria nos foros internacionais pertinentes, inclusive por meio do intercâmbio de informação, de acordo com nossas obrigações internacionais. Comprometemo- 
nos também a cumprir integralmente todas nossas obrigações assumidas nas convenções internacionais existentes sobre a matéria, em particular as da Organização Marítima Internacional. Tomamos nota ademais dos esforços dos países do Caribe, por meio da Resolução LIV/225 da Assembléia Geral das Nações Unidas, para elaborar e buscar-lhe o reconhecimento adicional para o conceito de Zona de Importância Especial para o Mar do Caribe no contexto do desenvolvimento sustentável.

34. Acolhemos com especial satisfação os resultados da VII Sessão da Conferência das Partes da Convenção sobre Diversidade Biológica e intensificaremos nossa cooperação com vista a pô-los em prática e dar-lhes seguimento.

35. Acolhemos com satisfação a realização da Reunião Bi-regional sobre Migração, celebrada em Quito, em 4 e 5 de março de 2004. Em consonância com seus resultados, continuaremos a promover um enfoque integral sobre a migração e tomaremos medidas adicionais para melhorar a cooperação e o conhecimento mútuo das realidades migratórias em ambas as regiões.

36. Visaremos enfrentar problemas importantes, tais como o pleno respeito dos direitos humanos de todos os migrantes, independentemente de seu estatuto; a necessidade de continuar a fortalecer a prevenção da migração irregular e o combate ao tráfico de seres humanos; a fuga-de-cérebros e seu impacto no desenvolvimento dos países de origem; o reconhecimento da contribuição dos migrantes ao desenvolvimento econômico e à vida social e cultural dos países de acolhimento; e a prevenção da violência e da discriminação contra migrantes, especialmente contra mulheres e menores, em conformidade com os compromissos internacionais pertinentes.

37. Os Estados da América Latina e do Caribe signatários da Convenção Internacional sobre a Proteção dos Direitos de Todos os Trabalhadores Migrantes e de suas Famílias enfatizam a importância que atribuem a esta Convenção no âmbito do sistema internacional de proteção dos direitos humanos.

38. Destacamos que as remessas dos migrantes são uma importante fonte de receita em muitos países. Cooperaremos, portanto, para facilitar a transferência dessas remessas e para reduzir seu custo, de acordo com a legislação nacional pertinente.

\section{Coesão Social}

39. Ressaltamos que a pobreza, a exclusão e a desigualdade além de serem afrontas à dignidade humana, debilitam a democracia e ameaçam a paz e a estabilidade. Reiteramos nosso compromisso de atingir as Metas de Desenvolvimento do Milênio até 2015 e destacamos nossa determinação de construir sociedades mais justas por meio do fortalecimento da coesão social, especialmente levando-se em conta os princípios da responsabilidade global comum. 
40. Reiteramos a responsabilidade primordial de nossos Governos, junto com suas sociedades civis, de liderar processos e reformas voltadas a aumentar a coesão social, por meio do combate à pobreza, à desigualdade, e à exclusão social. Ressaltamos a necessidade de se tomar medidas para combater a xenofobia e a discriminação, especialmente a em razão de gênero, raça, crença ou etnia, e, ao mesmo tempo, para garantir o respeito à diversidade cultural. Ressaltamos, ademais, a importância de se combater todo tipo de violência, em especial a contra as mulheres e a doméstica.

41. Ressaltamos nossa determinação de construir sociedades mais justas por meio da promoção do investimento social dirigido à educação em todos os níveis, nutrição, saúde, habitação, abastecimento d'água potável e saneamento, assim como a projetos de desenvolvimento de infra-estrutura com uso intensivo de mão-de-obra, a fim de reduzir a pobreza. Mecanismos financeiros inovadores de caráter multilateral são instrumentos essenciais para alcançar estes fins.

42. Destacamos a necessidade de dedicar uma proporção adequada dos gastos públicos aos setores sociais, à infra-estrutura básica e aos fundos nacionais de solidariedade, e de melhorar o acesso aos serviços sociais além de outras ações que beneficiem os grupos pobres e marginalizados, evitando-se dependência excessiva de financiamentos externos para estas políticas.

43. Promoveremos políticas econômicas que estimulem o investimento e a melhor distribuição de renda a fim de reduzir a desigualdade e a injustiça atuais, de tal forma que as conquistas macroeconômicas beneficiem os grupos populacionais em situação de desigualdade, pobreza e exclusão, fortalecendo assim a governabilidade democrática.

44. Reconhecemos que as políticas sociais e os regimes de proteção social deveriam estar apoiados em políticas públicas adequadas e justas, especialmente em políticas fiscais que permitam melhor distribuição da riqueza e que garantam níveis adequados de gasto social. Nesse sentido, reconhecemos a importância de se integrar a dimensão da coesão social às estratégias nacionais e aos processos de desenvolvimento.

45. Destacamos a importância de cumprir plenamente, e em todos seus aspectos, os compromissos assumidos na Conferência de Monterrey sobre o Financiamento do Desenvolvimento. Fazemos um apelo à comunidade internacional para que apoie nossos esforços nacionais para melhorar a coesão social. Promoveremos a cooperação nos campos das políticas sociais, migração, acesso efetivo aos mercados baseado em regras estáveis, assim como no do melhor acesso ao financiamento externo. As Instituições Financeiras Internacionais, o Sistema das Nações Unidas, os parceiros econômicos bilaterais e os doadores devem levar em consideração essas prioridades em seus programas.

46. Acreditamos que a Declaração e as Metas de Desenvolvimento do Milênio deveriam ser usadas como um marco abrangente para o diálogo político entre ambas as regiões, pois servem de base para a formulação de objetivos mensuráveis. 
47. Encorajamos os países da mesma região ou sub-região a continuar desenvolvendo seu diálogo regional ou sub-regional por meio do qual possam prosseguir, voluntariamente, o intercâmbio de informação sobre aspectos de coesão social de seus planos nacionais, assim como considerar metas comuns de coesão social e compartilhar experiências sobre êxitos e fracassos.

48. Promoveremos o intercâmbio de experiências entre países e regiões, com o apoio das instituições internacionais, sobre a formulação e implementação de políticas de coesão social. Articularemos as políticas sociais de nossos Estados e as orientaremos ao desenvolvimento de capacidades por intermédio de programas de educação, saúde, nutrição, saneamento, habitação, justiça e segurança, assim como à promoção do emprego digno e a criação de oportunidades econômicas para os mais pobres e ao estabelecimento de redes de proteção e solidariedade social para pessoas e famílias vulneráveis, no contexto do cumprimento das Metas de Desenvolvimento do Milênio.

49. Damos prioridade à coesão social como um dos principais elementos de nossa parceria estratégica bi-regional e nos comprometemos a cooperar para erradicar a pobreza, a desigualdade e a exclusão social. Fazemos um apelo à Comissão Européia, ao Banco Interamericano de Desenvolvimento, à Comissão Econômica para a América Latina e o Caribe, ao Programa das Nações Unidas para o Desenvolvimento, ao Fundo Monetário Internacional, ao Banco Europeu de Investimentos e ao Banco Mundial para que contribuam para se atingir este objetivo.

50. Resolvemos dar às questões sociais maior proeminência entre as prioridades de nossa cooperação bi-regional. Nesse contexto, acolhemos com satisfação a adoção do programa EUROsociAL, cujo objetivo é o de promover intercâmbio, entre ambas as regiões, de experiências, conhecimento especializado e boas práticas no campo social, especialmente nos setores educativo e de saúde, fundamentais para aumentar a coesão social.

\section{Relacionamento Bilateral}

51. Enfatizamos a importância dos acordos projetados entre a União Européia e as sub-regiões da América Latina e o Caribe, os quais, junto com os acordos já existentes e os que estão em negociação, permitir-nos-ão continuar a construir nossa parceria estratégica bi-regional.

52. Acolhemos com satisfação a assinatura dos Acordos de Diálogo Político e de Cooperação entre a União Européia e as regiões da América Central e da Comunidade Andina, em 15 de dezembro de 2003, em Roma. Em vista do progresso alcançado, reconfirmamos o sinal positivo dado na Declaração de Madri em relação às negociações de Acordos de Associação, inclusive os acordos de livre comércio. Tais Acordos de Associação são nosso objetivo estratégico comum. As partes reconhecem que a perspectiva de Acordos de Associação deverá dar novo ímpeto ao fortalecimento e melhoria dos processos de integração econômica regional.

53. Acolhemos com satisfação a decisão das partes interessadas de dar 
início de imediato ao processo conducente a tais Acordos. Esse processo começará, nesta fase, com uma apreciação conjunta com a América Central e a Comunidade Andina de seus respectivos processos de integração. A fase de apreciação conduzirá, no seu devido tempo, às negociações. Não pouparemos esforços para assegurarmo-nos de que a Rodada de Doha avance o máximo possível em 2004 para a sua rápida conclusão. Qualquer futuro Acordo de Livre Comércio será baseado no resultado do Programa de Trabalho de Doha, assim como também na realização de um nível suficiente de integração econômica regional.

54. Acolhemos com satisfação o progresso alcançado na negociação do Acordo de Associação Inter-regional entre o Mercosul e a União Européia. Cremos ser possível alcançar um resultado equilibrado e ambicioso com base nos esclarecimentos e nas atuais ofertas. Instruimos nossos negociadores a intensificarem seu trabalho para que este resultado possa ser alcançado até a data prevista de outubro de 2004.

55. Reconhecemos a importância da negociação do Acordo de Parceria Econômica entre os países do Caribe e a União Européia e acolhemos com satisfação o lançamento dessas negociações, no âmbito do Acordo de Cotonou. Esperamos que tais negociações sejam concluídas exitosamente e enfatizamos que esse Acordo deve ser um efetivo instrumento para o desenvolvimento sustentável.

56. Acolhemos com satisfação a iniciativa do Grupo do Rio para o estabelecimento de mecanismos financeiros inovadores cuja intenção é fortalecer a governabilidade democrática e enfrentar a pobreza, como uma resposta adicional da comunidade internacional para atender as demandas sociais básicas, os investimentos produtivos e a geração de emprego. Observamos com interesse os avanços para assegurar que as metas fiscais e práticas contábeis levem em consideração a capacidade de criação de ativos dos investimentos para a geração de capital social e ao financiamento de projetos de infra-estrutura.

57. Ressaltamos a importância do papel do Banco Europeu de Investimento, Banco Interamericano de Desenvolvimento, Banco de Desenvolvimento do Caribe, Corporação Andina de Fomento, Banco Centroamericano de Integração Econômica e outros bancos regionais em apoiar o investimento produtivo, sobretudo para a promoção do desenvolvimento sustentável e da

integração de infra-estruturas regionais. Nesse sentido, reconhecemos igualmente a relevância do Banco Mundial.

58. Acolhemos com satisfação as iniciativas em curso relativas a fontes de financiamento inovadoras como meio para combater a fome e a pobreza, para fortalecer a governabilidade democrática e apoiar o desenvolvimento sustentável. Tomamos nota do progresso realizado no estabelecimento de diversos fundos para dirigir recursos a estes fins. Acolhemos com satisfação a Declaração de Genebra sobre Ações contra a Fome e a Pobreza, e a reunião de líderes mundiais convocada pelo Brasil, à véspera da sessão inaugural da LIX Assembléia Geral das Nações Unidas. Tomamos nota, 
igualmente, da iniciativa da Venezuela de estabelecer um Fundo Humanitário Internacional e da proposta do Reino Unido de estabelecer um Fundo Financeiro Internacional.

59. Comprometemo-nos a combater o HIV/AIDS por meio de medidas preventivas combinadas com a adequada atenção médica e o acesso aos medicamentos para todos os afetados. Reafirmamos nosso apoio à Declaração de Compromisso na Luta Contra o HIV/AIDS adotada pela Sessão Especial da Assembléia Geral das Nações Unidas sobre HIV/AIDS, de 27 de junho de

2001.

60. Estamos comprometidos com os princípios do trabalho decente proclamados pela Organização Internacional do Trabalho, convictos de que o respeito pelos direitos e pela dignidade dos trabalhadores é vital para conseguir a redução da pobreza e o desenvolvimento social e econômico sustentável de nossos povos.

61. Comprometemo-nos a fortalecer os mecanismos de cooperação dirigidos a grupos vulneráveis e excluídos dentro de nossas sociedades, atribuindo especial atenção ao combate à discriminação e à promoção da participação ativa de minorias e de povos indígenas nas políticas e programas públicos que os afetem. Atribuiremos também prioridade à promoção da igualdade de gêneros. Com este fim, reconhecemos a necessidade de se eliminar os obstáculos estruturais e de se promover o papel da mulher na sociedade.

62. Enfatizamos a necessidade de se proteger os direitos das pessoas com deficiências. Nesse sentido, trabalharemos ativa e construtivamente para concluir, o mais cedo possível, a Convenção das Nações Unidas sobre este tema, no âmbito do Comité Ad Hoc das Nações Unidas sobre uma Convenção Internacional Abrangente e Integral para a Proteção e Promoção dos Direitos e da Dignidade das Pessoas com Deficiências.

63. Reiteramos nosso compromisso com a promoção e proteção dos direitos da criança, que deverão ser uma prioridade das políticas e programas sociais de nossos Governos, a fim de garantir o efetivo exercício de seus direitos. Nesse sentido, o interesse superior das crianças deverá ser prioritariamente considerado em todas as ações referentes à infância. Fazemos um apelo à ratificação universal da Convenção sobre os Direitos da Criança.

64. Comprometemo-nos a manter a Conferência das Nações Unidas sobre o

Comércio e o Desenvolvimento (UNCTAD) como o ponto focal do Sistema das Nações Unidas para se lidar com o tratamento integrado do comércio e desenvolvimento. Acreditamos que a XI UNCTAD, a ser realizada de 13 a 18 de junho de 2004, em São Paulo, Brasil, será o momento oportuno para se debater a importância do comércio para o crescimento econômico, o desenvolvimento sustentável e a redução da pobreza, de tal maneira que apóie a integração dos países em desenvolvimento na economia mundial e no Sistema Multilateral de Comércio, assim como a redução da diferença de 
renda-per-capita dentro dos países e entre o Norte e o Sul.

65. Nos comprometemos a unir esforços para que os resultados da XI UNCTAD fortaleçam a implementação das conclusões da Cúpula do Milênio, o Consenso de Monterrey e a Cúpula de Joanesburgo e apóiem as negociações do Programa de Trabalho de Doha.

66. Enfatizamos o potencial do comércio exterior como catalizador do crescimento econômico. Em nosso ponto de vista, podemos e devemos exercer um papel proeminente na construção de uma Organização Mundial de Comércio abrangente e inclusiva, que promova o progresso por meio da implementação dos objetivos de desenvolvimento contidos na Declaração Política e no Programa de Trabalho adotados na IV Reunião Ministerial da OMC, e que leve em consideração o tratamento especial e diferenciado, a fim de auxiliar na integração de países em desenvolvimento à economia mundial.

67. Afirmamos que o Programa de Trabalho de Doha oferece uma importante oportunidade para liberalizar ainda mais o comércio, mediante o maior acesso ao mercado e o fortalecimento das normas e disciplinas da OMC.

68. Reconhecemos a necessidade de assegurar benefícios a todos os países, em particular aos países em desenvolvimento, e reiteramos nosso forte compromisso de alcançar progresso significativo nas negociações em 2004.

69. Promoveremos medidas para melhorar o processo decisório e o funcionamento dos organismos financeiros internacionais, assim como para reformar a arquitetura financeira internacional, com vista a adotar medidas orientadas a prevenir e resolver satisfatoriamente as crises financeiras e a melhorar as condições financeiras dos títulos internacionais de endividamento, tendo em conta a situação dos países em desenvolvimento, especialmente dos mais vulneráveis, assim como a recorrência de crises e a severidade de seu impacto nos âmbitos nacional e internacional.

70. Empenhar-nos-emos para encontrar uma solução eficaz, justa e duradoura para o problema da dívida que afeta os países da América Latina e do Caribe, que leve em conta as metas prioritárias de desenvolvimento econômico e social dos países envolvidos, ao mesmo tempo em que essa solução deve ser congruente com os princípios de eqüidade e justiça social e apóie a erradicação da pobreza, da fome, do desemprego e da exclusão social.

71. Reconhecemos os benefícios do aperfeiçoamento da Iniciativa para a Redução da Dívida dos Países Pobres Altamente Endividados (HPICs) para os países elegíveis para esta forma de alívio de dívida e apoiamos sua total

implementação. Tomamos nota da aprovação, pelo Clube de Paris, do enfoque de Evian, que trata da dívida de países não elegíveis para a iniciativa HPIC, e reiteramos a necessidade de nos esforçarmos por manter e promover seu acesso aos mercados financeiros internacionais.

72. Reafirmamos nosso apoio aos compromissos adotados no Consenso 
de

Monterrey.

73. Intensificaremos os esforços para promover o desenvolvimento econômico sustentável e combater a pobreza, a fome e a exclusão. Recordamos o compromisso da comunidade internacional de trabalhar em prol de que os países desenvolvidos alcancem a meta de dedicar $0,7 \%$ de seus produtos internos brutos à ajuda oficial ao desenvolvimento.

74. Reconhecemos os desafios enfrentados pelas pequenas economias do Caribe em seus esforços para promover o desenvolvimento sustentável, erradicar a pobreza e melhor integrar-se à economia mundial.

75. Concordamos que atenção especial deve ser dada à situação dos países mais pobres em seus esforços para reduzir a pobreza.

76. Reconhecemos as características especiais dos Países em Desenvolvimento sem Litoral e dos Pequenos Estados Insulares, que merecem um enfoque adequado para atender suas necessidades e problemas específicos. Nesse sentido, destacamos a importância de se assegurar a implementação plena e efetiva do Programa de Ação de Almati, adotado em agosto de 2003, especialmente em relação ao transporte de trânsito.

77. Esperamos um resultado exitoso da Reunião Internacional para a Revisão Decenal do Programa de Ação de Barbados para os Pequenos Estados Insulares em Desenvolvimento, que será celebrada em Maurício no primeiro trimestre de 2005.

78. Ressaltamos também a importância de se apoiar os países de renda média, inclusive mediante a cooperação internacional, em seus esforços para erradicar a pobreza, aumentar a coesão social, assim como para promover o desenvolvimento econômico sustentável e o desenvolvimento institucional.

79. Reconhecemos a importância da integração regional e apoiamos os projetos concebidos para promover o desenvolvimento econômico, social, cultural e humano sustentável no âmbito regional. Continuaremos a cooperar de forma bi-regional no desenvolvimento e na institucionalização dos processos de integração na América Latina e no Caribe.

80. Enfatizamos a importância dos projetos de infra-estrutura física, como o Plano Puebla-Panamá, e a Iniciativa para a Integração da Infra-Estrutura Regional da América do Sul, pelo que encorajamos a participação de organizações financeiras multilaterais e de investidores particulares em tais projetos.

81. Comprometemo-nos a contribuir com o êxito do Quarto Fórum Mundial da Água, que se realizará em março de 2006, no México. Acolhemos com satisfação a "Iniciativa da União Européia sobre Água Componente Latino- Americano" e apoiamos seu futuro desenvolvimento. Reconhecemos a importância de se organizar uma conferência específica de seguimento acerca desse tema para facilitar sua implementação e futuros 
progressos. Apoiamos também o estabelecimento de um Mecanismo de Abastecimento da Água para países da África, do Caribe e do Pacífico e, neste contexto, continuaremos a explorar as oportunidades para enfrentar os desafios em matéria de água potável, saneamento e gerenciamento da água na região do Caribe, entre outras.

82. Ressaltamos nosso compromisso de promover a eficiência energética e de incrementar o uso de energias renováveis como um elemento importante no caminho do desenvolvimento sustentável. Os países participantes na Coligação para a Energia Renovável de Joanesburgo acolhem com satisfação as Parcerias de Energia Renovável e Eficiência Energética e encorajam os países que a ela ainda não se aderiram a que considerem fazê-lo. Este processo será avaliado na Conferência de Energia Renovável e Eficiência Energética em Bonn, Alemanha, de 1 a 4 de junho de 2004.

83. Exploraremos novas formas de produzir energia, como as que utilizam hidrogênio e células de combustível, assim como formas de empreender esforços de pesquisa conjunta nesta área.

84. Reiteramos a importância da cooperação entre a América Latina e o Caribe e a União Européia na luta contra a pobreza e no cumprimento das metas de desenvolvimento e coesão social e reiteramos nosso compromisso, adotado na Cimeira de Madri, de se intensificar a cooperação entre nossas duas regiões, que desempenha papel crucial na consolidação de nossa parceria estratégica.

85. Ressaltamos o progresso alcançado na definição de uma estratégia de cooperação bi-regional. Acolhemos com satisfação a criação do mecanismo para a apresentação e difusão de projetos bi-regionais, apresentado na Costa Rica, em março de 2004, e manifestamos nosso compromisso com sua plena implementação, que deverá permitir melhor participação de ambas as regiões na formulação, planejamento, execução e avaliação de iniciativas e projetos bi- regionais. Solicitamos uma avaliação, antes da próxima Cimeira, dos resultados até então alcançados.

86. Promoveremos a alocação de recursos para a cooperação bi-regional, a fim de fortalecer o processo de associação entre a América Latina e Caribe e a União Européia.

87. Manifestamos nosso profundo interesse em seguir apoiando os programas e projetos de cooperação - como AL-Invest, @Lis; URB-AL, ALFA, AlBan -, e também nossa vontade de reforçar o enfoque descentralizado em que se baseiam estes programas, a fim de aumentar sua futura cobertura, em termos de participantes e beneficiários, de ambas as regiões, em programas similares. 
88. Comprometemo-nos a explorar formas de estender aos países do Caribe os benefícios destes ou de outros programas similares.

89. Concordamos em prolongar até 2008 o Plano de Ação 20022004 para Construir um Espaço Comum de Educação Superior entre a América Latina e o Caribe e a União Européia. Os países participantes fazem um apelo aos outros países em ambas as regiões para que se unam a fim de assim contribuirem para a melhoria da qualidade do ensino superior. Convidamos os ministros correspondentes a que se reunam em 2004 para conceber programas, projetos e ações para o Plano de Ação 2004-2008. Pedimos-lhes que considerem, conforme o caso, as propostas feitas pelas instituições de nível superior e pelas associações e redes universitárias.

90. Também encorajamos a participação de instituições de nível superior e de pesquisa das duas regiões no Programa Erasmus Mundus.

91. Reforçaremos o vínculo entre desenvolvimento e cultura. Reconhecemos o vínculo indissolúvel entre o desenvolvimento, cultura e ciência te cnologia. Concordamos em promover um diálogo cultural biregional em setores que reflitam a identidade cultural, assim como a diversidade cultural e lingüística, e que beneficiem o desenvolvimento humano como uma contribuição ao desenvolvimento sustentável, à estabilidade e à paz. Nesse sentido, apoiamos as negociações em curso sobre uma Convenção sobre a Diversidade Cultural na UNESCO.

92. Reafirmamos nossa convicção de que as indústrias culturais contribuem de maneira fundamental a promover a identidade cultural e a diversidade lingüística e cultural. Reconhecemos também a importante contribuição das indústrias culturais para a promoção do desenvolvimento sustentável. Examinaremos os meios para melhorar a cooperação e a interação da América Latina e Caribe - União Européia neste âmbito.

93. Consideramos que a futura área de conhecimento da América Latina e o Caribe - União Européia deve ser baseada nos resultados de um bemsucedido diálogo bi-regional sobre ciência e tecnologia, e inclua o fortalecimento da cooperação em ciência e tecnologia, educação superior, inovação e tecnologias de informação e comunicação. Considerando a importância da Ciência e da Tecnologia para o desenvolvimento econômico e social de nossos países, e guiados pelo resultado das reuniões ministeriais e dos grupos de trabalho bi-regionais que trabalham em cooperação científica e tecnológica, concordamos em lançar uma Parceria em Ciência e Tecnologia com a finalidade de incluir a América Latina e o Caribe como uma região alvo para os Programas-Quadro da União Européia nestes setores, contribuindo-se assim para aprofundar e desenvolver os vínculos bi-regionais e incentivar a participação mútua em programas de pesquisa.

94. Concordamos em que deverão ser objetivos essenciais das políticas que têm como meta a criação de uma Sociedade da Informação o acesso universal e a redução do lapso digital. Desenvolveremos os marcos reguladores e melhoraremos o desenvolvimento da infra-estrutura e das aplicações 
necessárias para oferecer amplo acesso à Sociedade da Informação, de acordo com os compromissos expressos na Declaração de Princípios e no Plano de Ação da Cúpula Mundial sobre a Sociedade da Informação. Em vista do impacto social das tecnologias de informação e comunicação, solicitamos aos Ministros de ambas as regiões que levem em consideração os aspectos de coesão social na agenda do próximo Fórum da Sociedade da Informação da América Latina e Caribe - União Européia.

95. Consideramos que a navegação por satélite tem o potencial de trazer diversos benefícios aos usuários em todo o mundo. Comprometemo-nos a avaliar a possibilidade de se cooperar estreitamente nesta área.

96. Reafirmamos o compromisso de fortalecer nossa cooperação com vista a facilitar uma gestão eficiente em todas as fases dos desastres naturais ou os provocados pelo homem, com particular ênfase na prevenção e na mitigação. Acolhemos com satisfação as iniciativas já em curso para estudar a viabilidade de se estabelecerem iniciativas bi-rregionais voltadas a reduzir a vulnerabilidade dos países da América Latina nesse campo.

97. Reconhecemos que a Associação dos Estados do Caribe (AEC) é uma importante entidade regional por intermédio da qual as relações entre a União Européia e a Área do Grande Caribe podem ser aprofundadas e consolidadas. Acolhemos com satisfação o progresso realizado pelos 28 membros da AEC na consolidação de uma Zona de Cooperação da Área do Grande Caribe, por meio do diálogo político, da cooperação, das consultas e ações coordenadas nos campos do comércio, turismo sustentável, transporte e desastres naturais.

98. Reiteramos a importância crucial de se melhorar a capacidade da comunidade internacional de prevenir e responder de forma abrangente e coletiva, mediante a cooperação internacional, às graves crises humanitárias resultantes de desastres naturais ou causadas pelo homem, de acordo com o Direito Internacional e com a Carta das Nações Unidas, e levando-se também em conta a Resolução XLVI/182 da Assembléia Geral.

99. Expressamos nossas mais sinceras condolências aos familiares das vítimas das recentes inundações no Haiti e na República Dominicana. Fazemos um apelo à comunidade internacional para que preste ajuda humanitária de emergência. Reconhecendo a gravidade da situação, a União Européia está trabalhando, em estreita cooperação com as autoridades nacionais e com os parceiros da América Latina e do Caribe, entre outros, com vista a reagir com urgência e eficácia para ajudar na recuperação e melhorar sua capacidade de prevenção e atenção a desastres.

100. Continuaremos a promover o diálogo e a consulta com a sociedade civil e o acesso oportuno dos cidadãos às informações, no contexto dos processos de parceria e associação bi-regional.

101. Acolhemos com satisfação o relato do resultado das diversas reuniões celebradas nos últimos meses no âmbito bi-regiona

102. Acolhemos com satisfação o diálogo regular entre os parlamentares, autoridades locais e regionais, comunidades empresariais, assim como a 
sociedade civil organizada, com o fim de fortalecer nossa Parceria Estratégica.

103. Aceitamos de bom grado o convite da Áustria para celebrar a IV Cimeira da América Latina e Caribe - União Européia, em 12 e 13 de maio de 2006.

104. Manifestamos nossa profunda gratidão ao povo e ao Governo do México por toda sua cortesia e apoio, pois assim garantiram o exitoso resultado da Cimeira de Guadalajara. 


\title{
QUARTA CIMEIRA UE-ALC Viena, Áustria, 12 de Maio de 2006
}

\author{
DECLARAÇÃO DE VIENA
}

\section{REFORÇAR A ASSOCIAÇÃO ESTRATÉGICA BIREGIONAL}

1. Nós, Chefes de Estado e de Governo da União Europeia e da América Latina e Caraíbas, reunidos em Viena, a 12 de Maio de 2006, reiteramos o nosso compromisso em continuar a promover e reforçar a nossa parceria estratégica a nível bi-regional, tal como acordado nas cimeiras anteriormente realizadas no Rio de Janeiro, em Junho de 1999, em Madrid, em Maio de 2002, e em Guadalajara, em Maio de 2004.

2. Congratulamo-nos com os resultados positivos alcançados na Quarta Cimeira UE-ALC, que contribuirão para o fortalecimento da nossa relação, já de si sólida, abrangente e mutuamente benéfica. Alargaremos e aprofundaremos a cooperação UEALC em todos os domínios, num espírito de respeito mútuo, igualdade e solidariedade. Tirando partido dos especiais laços históricos e culturais que nos unem, estamos determinados a maximizar as potencialidades de actuação conjunta das nossas regiões.

3. Recordando as declarações das anteriores cimeiras do Rio de Janeiro, de Madrid e de Guadalajara, continuamos empenhados em honrar os compromissos nelas assumidos. Reiteramos, em especial, o nosso compromisso nos princípios e valores fundamentais comuns em que se baseia a nossa relação bi-regional e que estão consagrados na Carta das Nações Unidas.

É nossa firme convicção que a democracia, o Estado de direito, o respeito, a promoção e a protecção dos direitos humanos, a erradicação da pobreza, o desenvolvimento social e económico e o respeito pelo direito internacional são essenciais para a paz e a segurança. Reiterando ainda o nosso compromisso comum num sistema multilateral sólido e eficaz, estamos determinados, nesse sentido, a fazer avançar a agenda multilateral enquanto tema transversal e prioritário nas nossas relações bi-regionais.

Intensificaremos os nossos esforços no sentido de definir posições comuns e acções conjuntas entre as duas regiões no âmbito dos vários órgãos das Nações Unidas e nas principais conferências desta Organização. 
4. Reafirmamos que a democracia é um valor universal, baseada na livre expressão da vontade dos povos de determinarem os seus próprios sistemas políticos, económicos, sociais e culturais e a sua plena participação em todos os aspectos das suas vidas. Reafirmamos igualmente que, embora os regimes democráticos se caracterizem por elementos comuns, a democracia não se pauta por um modelo único nem é exclusivo de nenhum país ou região, e reiteramos que é necessário respeitar devidamente a soberania, a integridade territorial e o direito à autodeterminação.

Salientamos que a democracia, o desenvolvimento e o respeito por todos os direitos humanos e liberdades fundamentais são interdependentes e se reforçam mutuamente, constituindo princípios fundamentais da nossa parceria estratégica a nível bi-regional.

Aplaudimos a decisão da Cimeira Mundial de 2005 de criar um Conselho dos Direitos Humanos, bem como o passo histórico dado pela Assembleia Geral ao decidir torná-lo operacional. Ambas as regiões atribuem grande importância a que o novo Conselho se reúna em 19 de Junho de 2006.

Manteremos uma estreita cooperação no sentido de reforçar as políticas, os mecanismos e os instrumentos das Nações Unidas com vista à promoção e protecção efectivas dos direitos humanos. Também intensificaremos a promoção e a protecção dos direitos humanos nas nossas políticas nacionais.

5. Empenhar-nos-emos no sentido de garantir a plena igualdade entre os sexos, zelando particularmente para que as mulheres usufruam integralmente de todos os direitos humanos e pelo seu ulterior desenvolvimento, reiterando a Declaração e a Plataforma de Acção de Pequim e os documentos resultantes da Conferência Pequim+5. Asseguraremos o respeito e a aplicação dos direitos da criança e garantiremos que seja prestada a devida atenção às necessidades das pessoas com deficiência e de outros grupos vulneráveis.

Continuaremos a avançar na via da promoção e da protecção dos direitos e liberdades fundamentais dos povos indígenas a nível local, nacional, regional e internacional. $\mathrm{O}$ pleno exercício de tais direitos constitui um factor essencial para a sua existência, bemestar e desenvolvimento integral, bem como para a sua plena participação na sociedade.

Continuaremos igualmente a promover, a todos os níveis, os direitos e as liberdades fundamentais das pessoas que pertencem a minorias.

6. Afirmamos que o racismo é incompatível com a democracia e não pouparemos esforços para o combater bem como todas as formas de discriminação, xenofobia e intolerância, garantindo a plena implementação da Declaração e do Programa de Acção de Durban. 
7. As pessoas, organizações ou instituições que actuam na promoção e protecção dos direitos humanos, incluindo os defensores dos direitos humanos, devem beneficiar de apoio e protecção em moldes coerentes e eficazes, em conformidade com o direito internacional e com a Resolução 53/144 da AGNU sobre o Direito e a Responsabilidade dos Indivíduos, Grupos ou Órgãos da Sociedade de Promover e Proteger os Direitos Humanos e Liberdades Fundamentais Universalmente Reconhecidos.

8. Registamos com interesse a proposta da XVII Conferência Interparlamentar UEALC de criar uma Assembleia Euro-Latino-Americana (Lima, Peru, 14 a 17 de Junho 2005).

9. Acolhemos com satisfação a realização do Terceiro Fórum da Sociedade Civil da Europa, da América Latina e das Caraíbas (Viena, 30 de Março - 1 de Abril de 2006).

10. Acolhemos com igual satisfação a realização da Quarta Reunião das Organizações da Sociedade Civil da Europa, da América Latina e das Caraíbas (Viena, 5-7 de Abril) e tomamos nota das respectivas conclusões.

\section{REFORÇO DA ABORDAGEM MULTILATERAL PARA A PROMOÇÃO DA PAZ, DA ESTABILIDADE E DO RESPEITO PELO DIREITO INTERNACIONAL}

11. Recordando a Cimeira Mundial de 2005, no âmbito das Nações Unidas, reafirmamos o nosso compromisso com um sistema multilateral forte e eficaz, baseado no direito internacional, apoiado por sólidas instituições internacionais e centrado nas Nações Unidas. Reiteramos o nosso compromisso com uma ampla reforma $\mathrm{e}$ revitalização das Nações Unidas de molde a reforçar o seu carácter democrático e a sua representatividade, transparência, responsabilização e eficiência.

Saudamos, em especial, a criação de uma Comissão de Consolidação da Paz, cuja missão consiste em prestar aconselhamento e apresentar propostas relativas a estratégias integradas e coerentes para a consolidação da paz e a recuperação pós-conflito, centrando a atenção nos esforços de reconstrução nacional e de desenvolvimento institucional necessários à recuperação pós-conflito e lançando as bases para a paz e o desenvolvimento sustentável.

Daremos a devida consideração à representação de todos os grupos regionais na composição geral do Comité de Organização.

Apoiamos plenamente o sistema de segurança colectiva consignado na Carta das Nações Unidas. Manifestamos o nosso apoio a todas as operações de manutenção da paz com mandato das Nações Unidas e salientamos a necessidade de garantir o pleno respeito pelos direitos humanos em todas as operações de paz. 
12. Manifestamos o nosso apoio à MINUSTAH (Missão das Nações Unidas para a Estabilização no Haiti) e ao Grupo de Amigos do Haiti. Saudamos os progressos efectuados no sentido de melhorar as condições políticas, económicas e sociais. Comprometemo-nos a manter o nosso apoio e instamos a comunidade internacional a reforçar e garantir a cooperação com o Haiti. A este respeito, acolhemos com satisfação a realização da Reunião Ministerial Internacional que terá lugar a 23 de Maio, em Brasília.

13. Reafirmamos o nosso compromisso com os objectivos e princípios consagrados na Carta das Nações Unidas, bem como reafirmamos a nossa decisão de apoiar todos os esforços para respeitar a igualdade soberana de todos os Estados, respeitar sua integridade territorial e independência politica, abster-se de ameaçar ou utilizar a força nas relações internacionais de toda a forma não consentânea com os objectivos e princípios das Nações Unidas, defender a resolução de conflitos pelos meios pacíficos e em conformidade com os princípios de justiça e do direito internacional.

Rejeitamos com firmeza todas as medidas coercivas de carácter unilateral com efeitos extra- territoriais que sejam contrárias ao direito internacional e às regras de livre comércio comummente aceites. Concordamos que esse tipo de prática constitui uma séria ameaça ao multilateralismo. Neste contexto, recordando a Resolução 60/12 da Assembleia Geral das Nações Unidas, reafirmamos as nossas bens conhecidas posições sobre a aplicação das disposições extra territoriais da Lei Helms Burton.

14. Continuaremos a promover a observância do direito internacional e a reforçar o compromisso numa ordem internacional baseado em regras. A adesão universal aos princípios do Estado de direito e a confiança na capacidade do sistema para prevenir ou punir violações das regras constituem, hoje mais do que nunca, condições indispensáveis para uma paz e segurança duradouras. Recordamos o dever de resolução de litígios por meios pacíficos e incentivamos todos os Estados a recorrerem com mais frequência às instituições internacionais existentes para o efeito, entre as quais o Tribunal Internacional de Justiça. Manifestamos, além disso, o nosso pleno apoio ao Tribunal Penal Internacional; os Estados Partes apelam aos países que ainda o não tenham feito para que ratifiquem o Estatuto de Roma do TPI ou a ele adiram, consoante o caso, e para que cooperem com o Tribunal.

15. Estamos comprometidos com uma abordagem multilateral para enfrentar os desafios do desarmamento, não-proliferação e controle de armas, em especial as armas nucleares, químicas e biológicas, nos dias de hoje. Assim, prosseguiremos a implementação, universalização e reforço dos mecanismos de desarmamento e nãoproliferação, fortalecendo o papel das Nações Unidas.

Salientamos que o Tratado de Não Proliferação de Armas Nucleares continua a ser o pilar do regime de não-proliferação e base essencial para alcançar o objectivo de desarmamento nuclear, nos termos do Artigo VI. Reconhecemos o direito a desenvolver a investigação, a produção e a utilização da energia nuclear para fins pacíficos sem discriminação, nos termos do Tratado. 
Continuaremos a trabalhar para a adesão universal ao TNP. Nesse sentido, também reafirmamos a importância do Tratado Abrangente de Proibição de Testes Nucleares (CTBT) como parte do regime de desarmamento e não-proliferação nuclear. A proliferação de armas de destruição em massa e seus vectores de lançamento constituem crescente ameaça à paz e segurança internacionais. A comunidade internacional compartilha a responsabilidade por activamente prevenir esse risco. Para esse fim, estamos determinados,

em conformidade com as autoridades e a legislação nacional e em consonância com o direito internacional, a colaborar para a prevenção do tráfico ilícito de armas nucleares, químicas e biológicas, os seus vectores de lançamento e materiais relacionados.

16. Registamos o estabelecimento da Secretaria-Geral Ibero-Americana (SEGIB), que poderá contribuir para o reforço da presença bi-regional na cena internacional.

17. Reconhecemos os progressos efectuados pela Associação de Estados das Caraíbas (AEC) através do diálogo político, da cooperação e da realização de consultas, bem como de acções coordenadas nos domínios do comércio, do turismo sustentável, dos transportes e da resposta a catástrofes naturais, graças aos quais poderão ser aprofundadas e consolidadas as relações entre a UE e a região das Grandes Caraíbas.

\section{TERRORISMO}

18. Condenamos firmemente todos os actos terroristas, bem como o financiamento e o apoio ao terrorismo e a instigação de tais actos. Comprometemo-nos, através de uma cooperação mútua, a prevenir, combater e eliminar o terrorismo sob todas as suas formas e manifestações, onde quer e por quem quer que sejam cometidos. Manifestamos a nossa solidariedade para com as vítimas e suas famílias. Os actos de terrorismo afectam negativamente o usufruto dos direitos humanos e das liberdades fundamentais, constituem uma ameaça directa para o Estado de direito e subvertem o desenvolvimento económico e social. É dever dos Estados proteger os seus cidadãos. Impõe-se todavia que, ao combatermos o terrorismo, não destruamos aquilo que defendemos. No combate ao terrorismo, é imperioso que sejam respeitados os direitos humanos, o direito internacional humanitário, as liberdades fundamentais e o Estado de direito. Declaramos o nosso pleno apoio ao cumprimento de todos os compromissos assumidos nos termos dos instrumentos jurídicos das Nações Unidas para a luta contra o terrorismo e das resoluções 1373, 1566 e 1624 adoptadas nesta matéria pelo Conselho de Segurança das Nações Unidas, e outras resoluções pertinentes.

19. Instamos todos os Estados a recusarem dar guarida a presumíveis terroristas, bem como a empreenderem a seu respeito as devidas averiguações e acções judiciais e a analisarem prontamente os pedidos de extradição de pessoas suspeitas de terem cometido actos terroristas, em conformidade com o direito nacional e o direito internacional aplicável, acordos bilaterais inclusive. 
Instamos todos os Estados a tornarem-se Partes nas treze convenções e protocolos internacionais relativos ao terrorismo e salientamos a importância de que se reveste a implementação de tais instrumentos.

Apoiamos os esforços para a entrada em vigor da Convenção Internacional para a Repressão dos Actos de Terrorismo Nuclear. Salientamos ainda que é necessário tudo fazer para que, por ocasião da 60. ${ }^{a}$ sessão da Assembleia Geral, se chegue a acordo sobre e se adopte uma convenção abrangente relativa ao terrorismo internacional bem como apoiaremos os trabalhos da Assembleia Geral das Nações Unidas para definir uma estratégia de luta contra o terrorismo, tendo em conta o relatório do Secretário-Geral das Nações Unidas.

\section{DROGA E CRIMINALIDADE ORGANIZADA}

20. Reiteramos o nosso compromisso, de acordo com o princípio da responsabilidade partilhada, e com base numa abordagem global e integrada do problema mundial das drogas ilícitas, em reforçar a cooperação e aproveitar plenamente os mecanismos de diálogo e cooperação entre ambas as regiões, principalmente através do Mecanismo de Coordenação e Cooperação

UE-ALC de Luta contra as Drogas e do Diálogo de Alto Nível UE-Comunidade Andina sobre as Drogas. Reiteramos, em particular, o nosso compromisso em promover iniciativas sobre a partilha de informações policiais relativas ao tráfico de drogas e no domínio do desenvolvimento alternativo, incluindo o desenvolvimento alternativo preventivo, em países interessados, como forma de operar mudanças estruturais economicamente eficientes e duradouras em zonas vulneráveis às culturas ilícitas.

21. Assim, congratulamo-nos com a Declaração de Viena emitida em 7 de Março de 2006, por ocasião da conclusão da VIII Reunião de Alto Nível do Mecanismo de Coordenação e Cooperação UE-ALC de Luta contra as Drogas. Neste contexto, e com o objectivo de desenvolver e reforçar este Mecanismo, apoiamos a proposta de levar a efeito, até finais de 2006, uma revisão completa do Plano de Acção do Panamá, acordado em 1999, e dos domínios de acção da agenda de Lisboa.

22. Saudamos a entrada em vigor da Convenção das Nações Unidas contra a Corrupção (Convenção de Mérida) e sublinhamos a necessidade dos Estados que ainda não o tenham feito a assinarem, ratificarem e implementarem efectivamente essa Convenção.

De igual modo, sublinhamos a importância dos Estados que ainda não o tenham feito a considerarem a assinatura, ratificação ou adesão à Convenção contra o Crime Organizado Transnacional (Convenção de Palermo) e aos respectivos protocolos adicionais.

23. Comprometemo-nos a continuar a apoiar o Programa de Acção das Nações Unidas para Prevenir, Combater e Erradicar o Comércio Ilícito de Armas Ligeiras e de 
Pequeno Calibre. Para tal, reforçaremos a cooperação bi-regional e participaremos activamente na Conferência das Nações Unidas para analisar os progressos alcançados na implementação do Programa de Acção para Prevenir, Combater e Erradicar o Comércio Ilícito de Armas Ligeiras e de Pequeno Calibre, que se deverá realizar em Nova Iorque, de 26 de Junho a 7 de Julho

de 2006.

\section{AMBIENTE (INCLUINDO A PREVENÇÃO DAS CATÁSTROFES, A ATENUAÇÃO DOS SEUS EFEITOS E O GRAU DE PREPARAÇÃO PARA AS ENFRENTAR)}

24. Reconhecemos que a prosperidade a longo prazo das nossas regiões depende, em larga medida, da gestão sustentável dos recursos naturais e da capacidade para garantir um desenvolvimento que abranja todos os aspectos da sustentabilidade. Para tal, a UE e a ALC estabelecerão um diálogo a nível político para a troca de pontos de vista sobre questões ambientais de interesse mútuo.

Será prestada especial atenção à cooperação em domínios como as alterações climáticas, a desertificação, a energia, os recursos hídricos, a biodiversidade, as florestas e a gestão das substâncias químicas.

Reconhecemos a necessidade de iniciativas mais eficientes no domínio do ambiente no sistema das Nações Unidas, acompanhadas de uma coordenação reforçada, de uma melhor orientação e aconselhamento sobre políticas públicas a seguir, do reforço do conhecimento científico, da avaliação e da cooperação, de uma melhor observância dos tratados, sem que deixe de ser respeitada a autonomia jurídica de cada um deles, e de uma melhor integração das actividades ambientais no quadro mais abrangente do desenvolvimento sustentável a nível operacional, nomeadamente através da criação de capacidades; acordamos igualmente em explorar a possibilidade de criar um quadro institucional mais coerente para fazer face a esta necessidade, incluindo uma estrutura mais integrada, com base nas instituições existentes e nos instrumentos internacionalmente acordados, bem como nos órgãos instituídos pelos tratados e nas agências especializadas.

25. Congratulamo-nos com a declaração conjunta sobre a implementação da parceria estratégica UE-AL para os Recursos Hídricos e o Saneamento, assinada durante o $4 .^{\circ}$ Fórum Mundial da Água (México, 16-22 de Março de 2006). Reconhecemos o contributo prestado por este Fórum para a implementação das políticas adoptadas pela Comissão das Nações Unidas para o Desenvolvimento Sustentável.

26. Reiteramos o nosso firme compromisso em fazer face às alterações climáticas. Saudamos a entrada em vigor do Protocolo de Quioto e instamos os Estados que ainda não são Partes a que a ele adiram sem demora. Congratulamo-nos também com os resultados da Conferência de Montreal sobre as Alterações Climáticas (Dezembro de 2005). Reforçaremos a nossa cooperação para implementar os seus resultados, inclusive mediante a consideração dos compromissos dos países desenvolvidos que são parte no 
Protocolo de Quioto para os períodos subsequentes, bem como através da promoção de um diálogo orientado para o futuro sobre acções para lidar com as alterações climáticas no contexto da Convenção-Quadro das Nações Unidas sobre Alterações Climáticas. Cooperaremos ainda para aprofundar os nossos conhecimentos sobre o impacto e as vulnerabilidades às alterações climáticas, para aumentar as capacidades de adaptação, facilitar a transferência de tecnologias de mitigação e adaptação às alterações climáticas, e fortaleceremos também a nossa cooperação no âmbito do Mecanismo de Desenvolvimento Limpo.

27. Um esforço sem precedentes é, igualmente, necessário para que se atinja uma significativa redução da taxa de perda de biodiversidade em todos os níveis, até 2010. Saudamos, portanto, os resultados da Conferência de Curitiba sobre Diversidade Biológica (Março de 2006) e comprometemo-nos a aumentar os esforços para reforçar a implementação da Convenção sobre Diversidade Biológica e do Protocolo de Biosegurança pelos seus Estados Partes. Neste contexto, estamos igualmente comprometidos, na linha das decisões adoptadas em Curitiba, a continuar a elaboração e negociação de um regime internacional sobre o acesso a recursos genéticos e à repartição de benefícios, a fim de implementar efectivamente os três objectivos da CBD, a saber: a conservação da biodiversidade, o uso sustentável de seus componentes, e a distribuição justa e equitativa dos benefícios derivados da utilização dos recursos genéticos, bem como a implementar o Programa de Trabalho da CDB sobre Zonas Protegidas.

28. Reconhecemos o elevado grau de vulnerabilidade de algumas regiões a catástrofes naturais, bem como a sua crescente ocorrência e gravidade. Cooperaremos para reforçar a prevenção das catástrofes naturais e o grau de preparação para as enfrentar mediante o intercâmbio de experiências e a rápida divulgação das melhores práticas emergentes, em particular no domínio do controlo e do alerta rápido, bem como da criação de capacidades de resposta a nível local. Deste modo se poderá reforçar, no contexto do desenvolvimento sustentável, qualquer acção no sentido de uma abordagem integrada da gestão das catástrofes naturais com vista à redução do risco de catástrofe na Bacia das Grandes Caraíbas.

\section{ENERGIA}

29. Perante a rápida transformação dos parâmetros mundiais das políticas energéticas, reconhecemos a necessidade de uma cooperação regional e internacional mais estreita no sector da energia. Confirmamos o nosso compromisso em promover a eficiência energética e em aumentar a utilização das fontes de energia renováveis como passo importante no sentido de um abastecimento energético seguro, estável e competitivo, assim como do desenvolvimento sustentável.

Continuaremos a reforçar o diálogo e a cooperação bi-regional, nomeadamente no campo da energia renovável.

Congratulamo-nos com os esforços desenvolvidos para promover iniciativas no domínio 
da integração energética na América Latina e nas Caraíbas.

Saudamos ainda a realização do primeiro encontro de peritos da União Europeia e dos países da América Latina e das Caraíbas em matéria de energia, que teve lugar em Bruxelas a 20 e 21 de Abril de 2006.

30. Reconhecendo embora o direito soberano que assiste a cada país de gerir e regulamentar os seus recursos naturais, continuaremos a reforçar a cooperação com o objectivo de criar um quadro comercial equilibrado e regimes regulamentares mais compatíveis entre si. Sublinhamos a importância de desenvolver e investir na infraestrutura energética necessária para garantir a disponibilidade e o acesso a sistemas energéticos fiáveis e financeiramente suportáveis. Serão mantidos os esforços e incrementada a cooperação no sentido de acelerar o desenvolvimento de tecnologias energéticas ambientalmente sustentáveis.

\section{ACORDOS DE ASSOCIAÇÃO; INTEGRAÇÃO REGIONAL; COMÉRCIO; CONECTIVIDADE (INVESTIMENTO, INFRA-ESTRUTURA, SOCIEDADE DA INFORMAÇÃO)}

31. Congratulamo-nos com o êxito da implementação dos Acordos de Associação UE-México e UE-Chile e salientamos a importância de seguir uma estratégia biregional na negociação de outros Acordos de Associação, incluindo zonas de comércio livre.

Tomamos nota do progresso nas negociações entre o Mercosul e a União Europeia para celebrar um Acordo de Associação Inter-regional, e atribuímos a máxima importância ao objectivo de alcançar um acordo que seja ambicioso e equilibrado. Esse acordo deve reforçar as relações politicas, económicas, comerciais e de cooperação entre as duas partes, considerando os diferentes níveis de desenvolvimento.

As Partes interessadas saúdam o resultado da Reunião Ministerial realizada em Setembro de 2005 e instruem os negociadores a intensificar esforços para fazer avançar o processo negocial. Recordando o objectivo estratégico comum da Declaração de Guadalajara e tendo em conta o resultado positivo da avaliação conjunta sobre a integração regional efectuada com a América Central, saudamos a decisão adoptada pela União Europeia e a América Central para lançar as negociações para um Acordo de Associação, incluindo o estabelecimento de uma Zona de Comércio Livre.A América Central confirma os seus compromissos de implementarem, tal como acordado, as decisões tomadas pelos Chefes de Estado da América Central em 9 de Março de 2006 no Panamá, bem como de procurarem ratificar o Tratado sobre Investimentos e Serviços da América Central e a desenvolverem um mecanismo jurisdicional que garanta o cumprimento da legislação económica regional em toda a região.

Saudamos o envolvimento do Panamá neste processo. As Partes reconhecem que a sua participação activa nas negociações dar-se-á após a decisão formal da sua adesão ao processo de integração económica na América Central, SIECA.

As Partes interessadas partilham o objectivo de concluírem um acordo de associação abrangente e desejam um processo rápido de negociação, bem como uma efectiva implementação do futuro acordo de associação. A este respeito, as Partes reconhecem o 
valor do trabalho preparatório efectuado para este efeito pela Avaliação Conjunta do processo de negociação.

Recordando o objectivo estratégico comum estabelecido na Declaração de Guadalajara, congratulamo-nos com a decisão adoptada pela União Europeia e a Comunidade Andina de encetar, durante o ano de 2006, um processo conducente à negociação de um acordo de associação que inclua um diálogo político, programas de cooperação e um acordo comercial.

Para o efeito, a CAN e a UE acordam em realizar todas as reuniões necessárias antes de 20 de Julho próximo, a fim de clarificar e definir as bases da negociação, que permitam uma participação plena e frutífera para todas as partes.

Congratulamo-nos igualmente com os progressos alcançados nas negociações entre a UE e os países do Fórum das Caraíbas dos Estados ACP (CARIFORUM) sobre um acordo de parceria económica.

32. A integração regional constitui um elemento fundamental para a estabilidade, o crescimento económico e o investimento, assim como para aumentar o peso de ambas as regiões a nível mundial. Reafirmamos que os princípios da cooperação e da solidariedade constituem a base dos nossos processos de integração. Neste contexto, incentivamos e apoiamos firmemente os países da América Latina e das Caraíbas a prosseguirem os seus processos de integração regional.

Saudamos novas iniciativas como a criação da Comunidade Sul-Americana de Nações e a entrada em vigor do Mercado Único da CARICOM no âmbito do programa para o estabelecimento da Economia e Mercado Únicos da CARICOM (CSME).

33. Reiteramos o nosso inteiro apoio ao sistema multilateral de comércio e reafirmamos o compromisso assumido na Conferência Ministerial da OMC, realizada em Hong Kong, no sentido de concluir com êxito em 2006 as negociações iniciadas em Doha. Salientamos a importância central de que se reveste a dimensão do desenvolvimento em todos os aspectos do Programa de Trabalho de Doha, tal como é reiterada na Declaração de Hong Kong. Reconhecemos que um resultado ambicioso e equilibrado em todos as áreas de negociação é decisivo na criação de oportunidades para todos os membros da OMC, em especial mediante o reforço da efectiva integração e plena participação dos países em desenvolvimento no sistema multilateral de comércio e a criação de um clima seguro, estável e equitativo para o

comércio e o investimento, tendo presente que as contribuições devem ser consistentes com o princípio do tratamento especial e diferenciado. Por esse motivo, nos próximos meses, teremos de abordar todos as questões e nos comprometer a prosseguir as negociações no quadro do Compromisso Único. Continuaremos a ter em conta as especiais preocupações das pequenas e vulneráveis economias e dos Países Menos Desenvolvidos.

34. Incentivamos as instituições financeiras europeias, da América Latina e das Caraíbas a apoiarem a integração física através da interconectividade e da criação de 
infra-estruturas de rede, nomeadamente nos domínios da energia, dos transportes, das telecomunicações e da investigação. A promoção da interconectividade é parte integral de uma efectiva integração regional.

Neste contexto, reconhecemos as características especiais dos Países em Desenvolvimento sem Litoral e dos Pequenos Estados Insulares em Desenvolvimento, que deverão ser objecto de uma abordagem específica.

Congratulamo-nos com o apoio prestado pelo Banco Europeu de Investimento aos países da

América Latina e das Caraíbas.

\section{CRESCIMENTO E EMPREGO}

35. Reafirmamos o nosso compromisso em promover um crescimento económico equitativo e sustentado, para criar mais e melhores empregos e combater a pobreza e a exclusão social. Reconhecemos também a necessidade de promover a adopção de políticas públicas responsáveis que conduzam a uma melhor distribuição da riqueza e dos benefícios do crescimento económico. Sublinhamos a importância de definir políticas adequadas nos domínios fiscal e da protecção social, a fimm não só de promover um crescimento económico equitativo, com justiça social, capaz de criar empregos produtivos e de qualidade, mas também de procurar inserir o sector informal na economia formal. Acreditamos que a criação de trabalho decente constitui um elementochave para sustentar o desenvolvimento económico e social, prestando especial atenção ao problema do emprego juvenil, nomeadamente através da criação de capacidade técnica pela via das políticas de educação e de formação profissional. Comprometemonos a promover e facilitar o diálogo no contexto das relações laborais nos níveis nacional, sub-regional e bi-regional.

\section{LUTA CONTRA A POBREZA, A DESIGUALDADE E A EXCLUSÃO}

36. Sublinhamos o nosso compromisso em erradicar a pobreza, a desigualdade, a exclusão social e toda e qualquer forma de discriminação, a fim de melhorar as condições de vida de todos os indivíduos e grupos, consolidar a governação democrática e alcançar maior justiça social e o desenvolvimento sustentável.

Reconhecemos a necessidade de que sejam adoptadas estratégias e políticas públicas abrangentes e integradas para garantir maior igualdade de oportunidades e melhores condições de vida e de trabalho para todos, assim como um maior acesso à educação, à saúde e ao emprego, facilitando a igualdade de género e conferindo prioridade às populações mais vulneráveis, incluindo os deficientes. Reconhecemos a necessidade de elaborar políticas públicas especificamente vocacionadas para proteger as crianças e os jovens e para romper o ciclo da pobreza. Estas estratégias deverão dar resposta às necessidades sociais e económicas e às prioridades de cada país. 
Saudamos os progressos realizados no sentido de aumentar o acesso à educação e à saúde e salientamos a necessidade de melhorar ainda mais a cobertura e a igualdade de acesso de todos a esses serviços, inclusive mediante um financiamento justo, eficiente e de qualidade. Reconhecemos a importância de promover a responsabilidade social das empresas, estimular o diálogo social e a participação de todos os interlocutores relevantes, incluindo a sociedade civil, e respeitar a diversidade étnica, a fim de construir sociedades mais coesas.

37. Sublinhamos que a coesão social, fundamento de sociedades mais inclusivas, continua a ser nosso objectivo comum e uma prioridade essencial da parceria estratégica bi-regional. A promoção da coesão social visa contribuir para a construção de sociedades mais inclusivas, dando a todos a oportunidade de usufruir dos direitos fundamentais e acesso ao emprego, de gozar dos benefícios do crescimento económico com equidade e justiça social e de assim desempenhar plenamente o seu papel na sociedade. Continuaremos a atribuir à coesão social um elevado grau de prioridade nos nossos programas bi-regionais de cooperação e assistência, como o EurosociAL, e também continuar a promover o intercâmbio de experiências entre os nossos países e regiões.

38. Saudamos e apoiamos os resultados da Conferência de alto nível consagrada à "Promoção da coesão social: as experiências da UE e da ALC", que teve lugar em Bruxelas em Março de 2006.

Saudamos igualmente a iniciativa de organizar periodicamente fóruns consagrados à coesão social a fim de estimular o diálogo e a cooperação entre a UE e a América Latina e as Caraíbas em matéria de igualdade, erradicação da pobreza e inclusão social.

\section{COOPERAÇÃO PARA O DESENVOLVIMENTO E FINANCIAMENTO INTERNACIONAL PARA O DESENVOLVIMENTO}

39. Reafirmamos a nossa determinação em assegurar a consecução integral e dentro dos prazos das metas e objectivos de desenvolvimento aprovados nas principais conferências e cimeiras das Nações Unidas, conforme acordado no âmbito da Cimeira do Milénio, do consenso de Monterrey e dos resultados da Cimeira Mundial de 2005, bem como no quadro da Agenda de Doha para o Desenvolvimento.

40. É necessário promover esforços especiais tanto nos planos nacional, internacional como

bi-regional com o objectivo de garantir a plena realização do direito ao desenvolvimento para todos os povos e pessoas, conforme estabelecido na Declaração das Nações Unidas sobre o Direito ao Desenvolvimento.

41. Congratulamo-nos com a declaração conjunta da UE "O Consenso Europeu sobre o Desenvolvimento", que coloca a eliminação da pobreza no cerne da cooperação da UE para o desenvolvimento, no contexto do desenvolvimento sustentável, o que inclui a prossecução dos Objectivos de Desenvolvimento do Milénio (ODM), e que se 
aplica a todos os países em desenvolvimento. Reconhecemos os novos e ambiciosos compromissos assumidos pela UE tendo em vista melhorar os aspectos de quantidade, qualidade e eficácia da sua ajuda ao desenvolvimento. Reconhecemos, em particular, os compromissos dos Estados-Membros da UE no sentido de atingirem colectivamente até 2010 uma percentagem de $0,56 \%$ do RNB para a APD, e de se esforçarem por atingir a meta de $0,7 \%$ do RNB para a APD até 2015; os Estados-Membros que aderiram à UE após 2002 esforçar-se-ão por, até 2015, aumentar a percentagem APD/RNB para 0,33\%. Apelamos a todos os parceiros no desenvolvimento para que adiram a esta iniciativa europeia e sigam esta orientação. Congratulamo-nos com o apoio que continua a ser dado aos países de rendimento médio através da cooperação económica e para o desenvolvimento, em que se inclui a concretização de estratégias de eliminação da pobreza, tendo em conta o papel que desempenham em domínios políticos, comerciais e de segurança.

Reconhecemos também os esforços dos países da ALC para atingirem os ODM mediante a execução de políticas públicas orientadas para a integração social e o desenvolvimento humano sustentável.

42. Reconhecemos que a concretização dos Objectivos de Desenvolvimento do Milénio depende de recursos adicionais. Acolhemos, nesse sentido, os desenvolvimentos recentes da Acção contra a Fome e a Pobreza e a disposição de vários países para explorar e começar a implementar, em base voluntária, mecanismos financeiros inovadores para o desenvolvimento, como a taxa solidária nas passagens aéreas, a Facilidade Financeira Internacional e o projecto-piloto Facilidade Financeira Internacional para a Imunização, todos os quais foram discutidos na Conferência sobre Fontes e Mecanismos Financeiros Inovadores realizada em Paris, em Março último.

43. Constatamos que o VIH/SIDA e outras pandemias continuam a representar uma enorme ameaça para o futuro das nossas nações e para o desenvolvimento humano sustentável, e comprometemo-nos a intensificar a nossa colaboração na resposta às mesmas.

44. Consideramos que a importância das relações entre a UE e a ALC se deve reflectir na afectação de recursos à região.

45. Conferimos grande importância ao problema da divida enfrentado por alguns países e que requer um compromisso contínuo da comunidade internacional, com vista a encontrar soluções duráveis e equitativas, enfatizando que credores e devedores devem compartilhar responsabilidade para prevenir e solucionar situações insustentáveis de dividas de forma oportuna e eficiente.

Valorizamos os benefícios da Iniciativa para os Países Pobres Altamente Endividados (HIPC) reforçada e apoiamos a sua plena implementação nos países elegíveis. Registamos a aprovação, pelo Clube de Paris, da abordagem de Evian que prevê o tratamento da divida de países não elegíveis à Iniciativa HIPC, e reiteramos a necessidade de trabalhar para manter e promover o seu acesso aos mercados financeiros internacionais. 
46. Reconhecemos as iniciativas de base voluntária para ajudar alguns países da ALC, nomeadamente sob a forma de conversão da dívida em financiamento para o desenvolvimento, incluindo para a educação e programas de conversão de empréstimos APD e de créditos comerciais.

47. Continuaremos a promover a adopção de medidas que visem a melhoria do processo decisório, da governação e do funcionamento dos organismos financeiros internacionais, e bem assim a fortalecer a participação dos países em desenvolvimento nas Instituições Financeiras Internacionais, a fim de melhor traduzir os interesses dos referidos países e de dispor de instrumentos mais eficazes para prevenir e resolver crises. Neste contexto, saudamos as iniciativas tomadas pelo Fundo Monetário Internacional, como o Mecanismo contra Choques Exógenos (Exogenous Shocks Facility), para prestar ajuda financeira a países de baixo rendimento que enfrentem esse tipo de choque.

4.8 Registamos as conclusões da III Reunião dos Parlamentos de Integração Regional, realizada de 24 a 25 de Abril de 2006 em Bregenz, Áustria.

\section{MIGRAÇÃO}

49. Reconhecemos a necessidade de intensificar os benefícios da migração para ambas as regiões e para os próprios migrantes. Comprometemo-nos, pois, a levar adiante o nosso diálogo global em matéria de migração, reforçando mais ainda a nossa cooperação e nossa compreensão mútua da migração em todas as suas dimensões em ambas as regiões, e salientamos o nosso compromisso de proteger eficazmente os direitos humanos de todos os migrantes.

Congratulamo-nos com a realização em Cartagena das Índias, a 1 e 2 de Março de 2006, da segunda reunião consagrada ao tema da migração, em que participaram peritos da União Europeia e de países da América Latina e das Caraíbas.

Saudamos as recomendações no sentido de que seja efectuado um acompanhamento conjunto da situação relativa ao tratamento, aos direitos e à integração dos migrantes; à facilitação da transferência das remessas dos migrantes, de carácter privado, e à redução dos custos correspondentes; a novas abordagens no que respeita às políticas de migração; aos esforços conjuntos para tratar da migração irregular; e ao reforço da luta contra o tráfico de seres humanos, tendo em conta os direitos e a particular vulnerabilidade das pessoas sujeitas a estes crimes.

50. O diálogo de alto nível em matéria de migração e desenvolvimento internacionais, que terá lugar em Nova Iorque a 14 e 15 de Setembro de 2006, será uma excelente oportunidade para debater esta importante questão, em todos os seus aspectos, à escala mundial. 
PARTILHA DE CONHECIMENTOS E DESENVOLVIMENTO DE CAPACIDADES HUMANAS: ENSINO SUPERIOR, INVESTIGAÇÃO, CIÊNCIA E TECNOLOGIA, CULTURA

51. Reconhecemos o papel das tecnologias da informação e da comunicação (TIC) no apoio à coesão social, à integração regional e à competitividade das nossas economias. Atribuímos grande importância em colaborar para um maior desenvolvimento das TIC nas nossas regiões, a fim de promover o acesso universal, equitativo e financeiramente comportável a essas tecnologias, nomeadamente através de estratégias abrangentes capazes de fazer frente aos novos desafios e oportunidades da convergência tecnológica.

Congratulamo-nos com os resultados e com a declaração aprovada no Quarto Fórum Ministerial UE-ALC consagrado à sociedade da informação, sob o tema "Uma aliança para a coesão social através da inclusão digital", que se realizou em Lisboa em Abril de 2006. Reconhecemos os resultados encorajantes das actividades bi-regionais em curso neste campo e consideramos ser importante manter o apoio financeiro e político a iniciativas que consolidem o espaço de colaboração cientifica baseado nas TICs.

52. Consideramos prioritária a criação de um Espaço Comum do Ensino Superior UE-ALC, orientado para a mobilidade e a cooperação. Neste contexto, saudamos e encorajamos as decisões adoptadas na Conferência Ministerial realizada no México em Abril de 2005 e as recomendações mais recentes do Comité de Acompanhamento ALCUE. Acolhemos também com agrado a iniciativa da Comissão Europeia no sentido de intensificar substancialmente o seu programa de intercâmbios.

53. Reconhecemos a importância da C\&T para o desenvolvimento económico e social sustentável dos nossos países, inclusive para a redução da pobreza e a inclusão social. Registamos a reunião havida em Salzburgo, de 1 a 3 de Fevereiro de 2006, entre altos funcionários da UE e da ALC, e subscrevemos as suas conclusões.

Congratulamo-nos com a consolidação das plataformas UE-ALC para a C\&T, que levem ao reforço da parceria EU-ALC, promovendo um espaço de conhecimento UEALC concebido como um espaço comum de ciência, tecnologia e inovação. Instruímos os nossos altos funcionários UE-ALC da área da C\&T para promoverem a concepção, a execução e o acompanhamento da pesquisa e desenvolvimento conjuntos, a mobilidade, a inovação e a sensibilização do público para as actividades científicas em domínios de interesse comum para ambas as regiões no seu entendimento, tendo em vista fomentar a participação conjunta em actividades de investigação tais como o Sétimo Programa-Quadro e outros programas bilaterais e multilaterais.

54. Reconhecemos a importância da diversidade cultural enquanto factor de desenvolvimento, crescimento e estabilidade, conforme exemplificado pela aprovação, em Outubro de 2005, da Convenção da UNESCO para a Protecção e Promoção da Diversidade das Expressões Culturais. Apoiamos a sua rápida ratificação e implementação. 
Reconhecemos que a cooperação cultural é essencial para fomentar o diálogo intercultural e a compreensão mútua. Reafirmamos, além disso, a nossa convicção de que as actividades e indústrias culturais desempenham um papel importante na defesa, desenvolvimento e promoção da diversidade cultural. Comprometemo-nos a procurar meios que permitam reforçar tanto a cooperação UE-ALC como a cooperação intra ALC e os intercâmbios de conhecimentos e boas práticas neste domínio, além de incrementar a cooperação entre a UE e a ALC no quadro da UNESCO.

55. Acordamos em comemorar os bicentenários de vários eventos históricos e culturais, com o objectivo de contribuir para a aproximação dos laços entre os nossos povos.

\section{CONCLUSÕES}

56. Acolhemos com o maior agrado o relatório das diversas reuniões e actividades realizadas no plano bi-regional entre as Cimeiras de Guadalajara e Viena, no qual se destaca a contínua consolidação da nossa associação estratégica

57. Congratulamo-nos com a realização da $1 .{ }^{a}$ Cimeira Empresarial UE-ALC (Viena, 12 de Maio de 2006), subordinada ao tema "Aproximar os dois mundos através dos Negócios e da Cultura". Nela estiveram presentes importantes figuras das comunidades empresariais de ambas as regiões, às quais foi proporcionada uma plataforma para debaterem as relações comerciais, os investimentos, os serviços e as perspectivas de negócio. As conclusões e recomendações da cimeira foram-nos apresentadas durante a sessão plenária de encerramento da Quarta Cimeira UE-ALC.

58. Aceitamos com o maior agrado o convite do Peru para realizar a Quinta Cimeira UE-ALC em 2008.

59. Expressamos a nossa gratidão ao Governo e ao povo da Áustria por toda a sua hospitalidade e apoio, que contribuíram para assegurar o êxito da Cimeira de Viena. 


\title{
QUINTA CUMBRE AMERICA LATINA Y CARIBE - UNION EUROPEA Lima, 16 de mayo de 2008
}

\author{
DECLARACION DE LIMA
}

\section{“RESPONDIENDO JUNTOS A LAS PRIORIDADES DE NUESTROS PUEBLOS”}

Los Jefes de Estado y de Gobierno de América Latina y el Caribe y de la Unión Europea nos hemos reunido en Lima para dar renovado impulso al proceso de construcción de la asociación estratégica birregional que iniciamos en Río de Janeiro y proseguimos con firme voluntad política y ambicioso horizonte en Madrid, Guadalajara y Viena. Próximos a completar un decenio desde nuestro primer encuentro,

1. Reafirmamos nuestro compromiso con los principios y valores en los que se sustenta la relación birregional, así como con los objetivos compartidos, los compromisos y las posiciones conjuntas que hemos asumido desde Río de Janeiro hasta Viena.

2. Proseguiremos activamente las negociaciones de Acuerdos de Asociación como objetivos comunes estratégicos de muy alta prioridad política. Nos congratulamos de la exitosa implementación de los Acuerdos de Asociación de México y de Chile con la UE. La Unión Europea y el Foro del Caribe (CARIFORUM), como parte del grupo de Estados de África, Caribe y Pacífico (ACP), saludan la exitosa conclusión de las negociaciones para un Acuerdo de Asociación Económica.

Constatamos con satisfacción el inicio, en 2007, de las negociaciones entre la UE y América Central y la Comunidad Andina para Acuerdos de Asociación Bi- regional ambiciosos y comprensivos, que tomen en cuenta las asimetrías entre y al interior de cada una de las regiones. Constatamos el progreso efectuado tras las primeras tres rondas de conversaciones y reconfirmamos nuestros objetivos comunes de efectuar un progreso sustantivo en las negociaciones con la finalidad de permitir su conclusión durante el 2009.

Acogemos los esfuerzos en curso para alcanzar un acuerdo entre la Unión Europea y América Central. En esta perspectiva, recordamos la importancia de la integración regional tal como fue reconocida en la Cumbre de Viena, y reconocemos con satisfacción los resultados positivos alcanzados hasta el momento. Acogemos la decisión de Panamá de incorporarse formalmente al proceso de integración económica regional y esperamos con interés la pronta ratificación del Protocolo de Guatemala, como un primer paso.

Damos igualmente la bienvenida a la determinación de la Comunidad Andina y la Unión Europea de hacer todos los esfuerzos para concluir un Acuerdo de Asociación que contribuya a un mayor desarrollo del proceso de integración Andino. Acordamos que se dará una particular atención a las necesidades de específicas de desarrollo de los Países Miembros de la Comunidad Andina, tomando en cuenta las asimetrías entre y al interior de las regiones y la necesidad de flexibilidad, según corresponda, por parte de la UE. 
Subrayamos la importancia de un ambicioso y balanceado Acuerdo de Asociación Mercosur-UE y reiteramos nuestro compromiso para llevar las negociaciones a un resultado exitoso tan pronto como las condiciones lo permitan, sobre la base del trabajo existente ya alcanzado.

3. Tenemos una visión nítida del potencial de nuestra asociación estratégica birregional, la cual estamos decididos a conseguir. Con ese fin nos proponemos:

Fomentar el bienestar de nuestros pueblos para alcanzar sociedades más inclusivas y cohesionadas, donde el respeto al estado de derecho, a los valores y principios de la democracia y a los derechos humanos, prevalezca en un marco de solidaridad e igualdad. Trabajaremos por la igualdad de oportunidades y un mayor sentido de pertenencia ciudadana y participación individual y colectiva en los beneficios del progreso, ambos componentes esenciales para el desarrollo armónico de nuestros pueblos.

Profundizar la integración regional y otras formas asociativas, así como los procesos birregionales de diálogo político, cooperación y comercio, tomando en cuenta las asimetrías entre los países y entre nuestras dos regiones, a fin de facilitar el desarrollo conjunto de nuestras capacidades y potencial. Fortalecer el sistema multilateral haciéndolo más efectivo y reforzando su naturaleza democrática, teniendo a las Naciones Unidas como centro, a través de una mayor coordinación y cooperación ALC-UE, especialmente en aquellos asuntos en los que hemos emprendido iniciativas específicas, así como en temas globales de interés común.

4. Reafirmamos nuestro compromiso con los propósitos y principios consagrados en la Carta de las Naciones Unidas, reafirmamos nuestra decisión de apoyar todos los esfuerzos para defender la igualdad soberana de todos los Estados, respetar su integridad territorial e independencia política, abstenernos en nuestras relaciones internacionales de la amenaza o uso de la fuerza de manera inconsistente con los propósitos y principios de las Naciones Unidas; y preservar la resolución de controversias por medios pacíficos y en conformidad con los principios de la justicia y el Derecho Internacional.

Rechazamos con firmeza todas las medidas coercitivas de carácter unilateral y efecto extraterritorial que sean contrarias al Derecho Internacional y a las normas generalmente aceptadas del libre comercio. Coincidimos en que este tipo de prácticas representa una amenaza grave para el multilateralismo. En este contexto, y en referencia a la resolución A/RES/62/3 de la AGNU, reafirmamos nuestras bien conocidas posiciones sobre la aplicación de las disposiciones extraterritoriales de la Ley Helms-Burton.

5. Reafirmamos nuestro compromiso con la oportuna y exitosa conclusión de la Ronda de Desarrollo de Doha de la OMC y reiteramos nuestra voluntad de alcanzar un resultado ambicioso, comprensivo y equilibrado. Al respecto, vemos la próxima Reunión Ministerial de la OMC como una oportunidad clave para avanzar rápidamente hacia la conclusión de la Agenda de Desarrollo de Doha. 
6. Cooperaremos, en el marco del Derecho Internacional, en asuntos de seguridad (entre otros, tráfico de drogas ilícitas y de armas; crimen organizado y terrorismo, incluyendo la toma de rehenes), reconociendo la necesidad de abordar su impacto sobre las sociedades democráticas y su desarrollo.

7. Profundizaremos nuestra cooperación, de conformidad con el principio de responsabilidad compartida, para enfrentar el problema mundial de las drogas. El Mecanismo ALC-UE de Coordinación y Cooperación en materia de Drogas debería ser fortalecido como marco para un diálogo birregional más eficiente.

8. Profundamente preocupados por el impacto del incremento de los precios de los alimentos, reiteramos el compromiso de nuestros países con políticas para la erradicación del hambre y la lucha contra la pobreza. Estamos de acuerdo en que se necesitan medidas inmediatas para ayudar a los países más vulnerables y a las poblaciones afectadas por los altos precios de los alimentos. También estamos convencidos que, en el mediano y largo plazo, una respuesta duradera a la crisis actual requiere acciones coordinadas de la comunidad internacional, con miras al fortalecimiento de las capacidades agrícolas y del desarrollo rural, para poder satisfacer la creciente demanda.

En este contexto, tomamos nota del anuncio del Secretario General de la Organización de las Naciones Unidas acerca de la preparción de un Plan de Acción y trabajaremos para lograr resultados concretos en la Conferencia de Alto Nivel sobre la Seguridad Alimentaria Mundial que se celebrará en Roma, entre el 3 y el 5 de junio de 2008. Además apoyamos el desarrollo de la iniciativa "América Latina y el Caribe sin hambre" de la FAO y esperamos con interés los resultados de la Sesión Especial del Consejo de Derechos Humanos sobre el derecho a la alimentación.

9. Acogemos con agrado los esfuerzos del Gobierno y el pueblo de Haití para revitalizar sus instituciones estatales y luchar contra la pobreza, la desigualdad y las injusticias sociales. En este contexto, expresamos nuestro apoyo a MINUSTAH y al Grupo de Amigos de Haití. Reconocemos la necesidad de una acción continuada urgente y efectiva por parte de la comunidad internacional en favor de la rehabilitación y del desarrollo de Haití.

Reafirmamos nuestro apoyo a Haití en sus esfuerzos para atender las necesidades urgentes y de largo plazo de seguridad alimentaria. En este sentido, acogemos la organización de una conferencia sobre esta materia en España, en julio de 2008, presidida por Francia y Argentina en su papel de co- Presidencias ALC-UE, la cual estará orientada hacia la elaboración de un programa de seguridad alimentaria y desarrollo rural, en línea con el propio plan de Haití y coherente con los esfuerzos en curso de la comunidad internacional.

10. Superar la pobreza, la desigualdad y la exclusión es crucial para el logro de la cohesión social, para el desarrollo sostenible y para la eficacia de nuestra asociación birregional. La degradación ambiental y el cambio climático afectan seriamente nuestro crecimiento económico, perjudicando más a los pobres y amenazando seriamente todas las perspectivas de futuro de nuestros pueblo

Reconocemos que las acciones para responder a estos desafíos están interrelacionadas 
y deberían beneficiarse, cuando corresponda, de las sinergias para así promover el desarrollo sostenible. En este esfuerzo, reconocemos el papel de las instituciones financieras de desarrollo y la comunidad internacional de donantes de apoyar activamente el desarrollo social sostenible de nuestras sociedades.

En esta V Cumbre, hemos decidido centrar nuestras deliberaciones en la promoción de acciones a nivel nacional, regional e internacional para abordar dos desafíos claves relacionados entre sí: la pobreza, la desigualdad y la necesidad de sociedades más inclusivas; y el desarrollo sostenible, el medio ambiente, el cambio climático y la energía. Necesitamos implementar políticas ambiciosas y oportunas para enfrentar estos desafíos. Como resultado de nuestros debates, adoptamos la siguiente

\section{AGENDA DE LIMA}

\section{ERRADICACIÓN DE LA POBREZA, LA DESIGUALDAD Y LA EXCLUSIÓN}

11. Confirmamos que la lucha contra la pobreza, la desigualdad y la exclusión a fin de alcanzar o aumentar la cohesión social es una prioridad política clave de la asociación estratégica entre nuestras regiones. Ella continúa siendo un tema central para nuestro diálogo y cooperación a nivel nacional, subregional y regional. Reiteramos la responsabilidad primordial de nuestros gobiernos, en cooperación con todos los actores relevantes, entre ellos la sociedad civil, para implementar políticas que conduzcan a dicho objetivo.

12. Reconocemos el progreso registrado para el cumplimiento de los Objetivos de Desarrollo del Milenio, otorgamos gran importancia al llamado a la acción del Secretario General de Naciones Unidas respecto a los ODM y renovamos nuestro compromiso de alcanzarlos antes de 2015, así como nuestro compromiso con el Consenso de Monterrey, en particular con relación a la movilización de recursos nacionales e internacionales adicionales para la Ayuda Oficial al Desarrollo, inclusive para los países de renta media. Hacemos un llamado para que mecanismos financieros innovadores adicionales contribuyan al cumplimiento de estos objetivos, alentando consecuentemente a promover sociedades más inclusivas.

13. No obstante, observamos con preocupación que, a pesar del progreso alcanzado, la pobreza, la desigualdad y la exclusión continúan obstaculizando el acceso de diversos sectores de la población a la igualdad de oportunidades para beneficiarse de una vida digna y productiva, dificultan el bienestar de los individuos y fomentan el desplazamiento de personas. Abordar de manera efectiva la erradicación de la pobreza, la desigualdad y la exclusión, con miras a promover la cohesión social, constituye un imperativo moral, político y econômico. 
En el marco de los Derechos Humanos universales, incluyendo los derechos civiles, culturales, económicos, políticos y sociales, y las libertades fundamentales para todos sin discriminación, y a través del carácter cooperativo de nuestra asociación birregional, nos comprometemos a mejorar significativamente la calidad de vida de todos nuestros pueblos. Nos proponemos alcanzar:

Niveles de desarrollo social equitativos e inclusivos, a través del diseño e implementación de políticas sociales más efectivas.

Tasas sostenidas de crecimiento que promuevan, entre otros, la creación de trabajo decente, digno y productivo, optimizando así la recaudación fiscal para mejorar el gasto social y su impacto redistributivo.

Pleno sentido de pertenencia y participación de nuestros pueblos a todo nivel en la lucha contra la pobreza, la desigualdad y la exclusión, fortaleciendo la confianza de los ciudadanos en la efectividad de las instituciones democráticas y en las políticas de desarrollo social.

15. Para el logro de los objetivos antes mencionados, y adicionalmente a los programas birregionales existentes, promoveremos la identificación de otras formas de cooperación birregional con el fin de promover:

\section{El diseño y la implementación de políticas sociales efectivas que:}

16. Fomenten un uso coherente tanto de los recursos públicos como privados, que complementen la cooperación birregional y otros mecanismos internacionales de financiamiento para generar, por medio de la buena y responsable gobernanza y de políticas fiscales adecuadas, programas sociales que conduzcan al logro de los Objetivos de Desarrollo del Milenio para el 2015 y, en el caso de las metas adicionales asumidas por los países ALC, para el año 2020:

Erradicar la desnutrición y prevenir la malnutrición infantil, en especial en los niños menores de 3 años, en el marco de los esfuerzos conjuntos y sostenidos para eliminar el hambre en nuestros países y prestando atención al derecho a la alimentación y garantizando la seguridad alimentaria de nuestras poblaciones.

Universalizar la atención a las madres gestantes y a los recién nacidos, y el acceso progresivo a servicios de salud.

Erradicar progresivamente el analfabetismo.

Universalizar la educación preescolar, mejorar la calidad de la educación básica y ampliar la cobertura y calidad de la educación secundaria y superior.

Promover la educación profesional y vocacional.

Universalizar el acceso a servicios de agua potable y saneamiento. 
laboral.

Incrementar las tasas de empleo y establecer programas de formación

Mejorar las condiciones de vivienda de los grupos más vulnerables de la población.

17. Destinen los medios necesarios para fortalecer o, cuando sea necesario, promover reformas de los sistemas de protección social, reforzando así la solidaridad para incrementar significativamente la tasa de cobertura, universalizando el sistema $\mathrm{y}$ brindando asistencia específica a las poblaciones más vulnerables.

18. Estimulen la participación de las autoridades competentes y de todos los actores relevantes, entre ellos la sociedad civil, en redes ALC-UE para la transferencia de conocimientos y el intercambio de información en materia de políticas sociales, y promover el intercambio de experiencias, incluyendo las experiencias exitosas y proyectos piloto, y la difusión de buenas prácticas. Para este fin, trabajaremos en estrecha vinculación con EUROsociAL.

19. A partir de nuestra cooperación existente, provean metodologías e indicadores para la formulación, evaluación y seguimiento de las políticas sociales y laborales, incluyendo la capacitación de profesionales.

20. Consideren los requerimientos específicos de grupos objetivo, promoviendo una mayor igualdad de género y los derechos de las personas con discapacidad, de los niños, de los pueblos indígenas o de otros grupos sociales que requieran atención especial, así como las asimetrías en materia de desarrollo económico existentes entre los países y otras condiciones o características adversas específicas, incluyendo a los países en desarrollo sin litoral.

21. Tomen en cuenta, para los fines de esta Agenda, la valiosa contribución de los respectivos organismos del Sistema de Naciones Unidas en ambas regiones, así como el rol de las organizaciones de voluntariado humanitario.

\section{Un crecimiento económico con impacto distributivo que:}

22. A partir de los niveles alcanzados y considerando las necesidades específicas de cada país, busque asegurar un crecimiento estable y sostenido, por medio de políticas comerciales y económicas, de inversiones y laborales, que incorporen explícitamente los objetivos de equidad e inclusión. Reiteramos que las políticas y los regímenes de protección social deberían estar sustentados por políticas públicas ordenadas y justas, en particular por políticas fiscales, que permitan una mejor redistribución de la riqueza y garanticen niveles adecuados de gasto social. Para que esto sea efectivo, subrayamos la necesidad de:

$\underline{\text { Fomentar el crecimiento: }}$

Preservar y promover políticas macroeconómicas ordenadas y un clima seguro para la inversión, en un marco internacional que permita a nuestros países desarrollar sus 
capacidades nacionales para la producción de bienes y servicios de valor agregado cada vez mayor, así como la transferencia de tecnología e inversiones.

Promover políticas que favorezcan las economías formales y los mercados de trabajo, para profundizar los avances en la eliminación de las principales causas de la economía informal.

\section{Ampliar la cooperación:}

Fortalecer las iniciativas nacionales y la cooperación internacional, incluyendo la modalidad de apoyo presupuestario directo, cuando corresponda, a fin de asegurar mayores recursos para la implementación de políticas sociales viables e inversión pública con impacto redistributivo.

Adoptar, entre otras, medidas tales como el canje de deuda por inversión social (en salud, acceso al agua potable, educación y vivienda, entre otras), la constitución de asociaciones público-privadas, el acceso a nuevas fuentes de financiamiento, la constitución de fondos para la reconversión y solidaridad social, y fondos contra-cíclicos para financiar políticas sociales.

Complementar las capacidades de los países de renta baja y media con la cooperación ágil, directa y oportuna y fondos para el desarrollo económico, que permitan asegurar sus logros macroeconómicos, apoyando con recursos adecuados el aumento de inversión en educación, salud y vivienda, y procurando al mismo tiempo reducir los costos administrativos de esta cooperación.

Usar el nuevo mandato externo del Banco Europeo de Inversiones como una oportunidad para aumentar la inversión para el máximo beneficio de la región ALC.

23. Promover la consolidación de la integración comercial entre nuestras dos regiones, apoyar los procesos de integración regional en marcha y proveer mayores oportunidades para un acceso ampliado y más efectivo a sus respectivos mercados, mediante arreglos coherentes con las disposiciones de la OMC, eliminando los obstáculos injustificados al comercio y reduciendo los factores de distorsión, asegurando al mismo tiempo el tratamiento especial apropiado y diferenciado para los países en desarrollo y tomando en consideración la situación particular de las economías pequeñas y vulnerables.

Coincidimos en que el comercio es un motor para el crecimiento, el desarrollo sostenible y la reducción de la pobreza, y que las políticas comerciales y las estrategias de desarrollo tienen que ser formuladas con con miras a minimizar el impacto social negativo de la globalización y a maximizar su impacto positivo, asegurando al mismo tiempo que todos los sectores de la población, y en particular los más pobres, se beneficien de ello.

24. Promover el desarrollo de los activos productivos y la mejora de la productividad, la competitividad y en el intercambio de conocimientos, particularmente en zonas rurales y urbanas afectadas por la pobreza y en sectores altamente intensivos en mano de obra. Se debería recurrir a incentivos para promover a las pequeñas y medianas empresas (PYMEs), buscando su articulación con las cadenas de suministro nacional, regional y birregional. Proponemos que se consideren iniciativas 
para promover el seguimiento y el intercambio de información sobre el desempeño de las pequeñas y medianas empresas, para enfocar mejor la cooperación para su desarrollo y así fortalecer el conocimiento existente y la información que permitirá mejorar las políticas públicas nacionales relacionadas.

25. Desarrollar políticas laborales y de empleo más efectivas, a través del dialogo social y la cooperación de los gobiernos, empleadores y trabajadores y la implementación de la responsabilidad social de las empresas y el respeto de los derechos de los trabajadores, incluyendo la negociación colectiva, con miras a generar trabajo decente, digno y productivo para todos. Dichas políticas deberían orientarse particularmente a los jóvenes y a ampliar la cobertura de los mecanismos de seguridad social. Por consiguiente, apoyaremos programas para:

Facilitar el empleo de calidad para los jóvenes y reducir sustancialmente la proporción de jóvenes que están fuera del sistema educativo o del mercado laboral.

Incrementar la capacitación y la formación laboral, dando especial énfasis al desarrollo de competencias transversales y a la formación continua que contribuyan a la adaptación a los cambios en el mercado laboral.

Incorporar a los trabajadores de la pequeña y mediana empresa (PYME) y a los trabajadores independientes en los sistemas de protección social.

Desarrollar mercados para la producción de bienes de consumo por sectores vulnerables, tales como pobladores rurales, comunidades nativas y pueblos indígenas, para mejorar sustancialmente sus condiciones de trabajo, así como aumentar su productividad e ingresos.

Promover los beneficios de los mercados laborales nacionales que proporcionan adaptabilidad y seguridad social, formación laboral y formación continua.

Promover el uso de la tecnología de la información y las comunicaciones para facilitar nuevas oportunidades de empleo, mejor educación y acceso a servicios de salud. En ese contexto, desarrollaremos la infraestructura de comunicaciones para reducir la brecha digital, al amparo de programas como @lis, y ampliaremos la interconexión entre las redes CLARA, GEANT y CKLN.

\section{Participación social y sentido de pertenencia que:}

26. Reconozca, sobre la base de un pleno respeto a la diversidad, que es esencial ampliar la participación de los ciudadanos en el proceso de diseño e implementación de políticas y programas sociales, a fin de fomentar la inclusión social y fortalecer la confianza de los ciudadanos en las instituciones democráticas, contribuyendo así a la buena gobernanza. Para tal efecto promoveremos:

El fortalecimiento de los mecanismos nacionales de diálogo para definir las prioridades de las políticas sociales y laborales. 
El reforzamiento de los mecanismos institucionales para garantizar el debido respeto de los derechos sociales.

El empoderamiento económico, político y social de la mujer.

Mayor transparencia y responsabilidad frente a los ciudadanos por parte de las instituciones públicas a todos los niveles e instituciones de control efectivas.

Cooperación entre las autoridades locales de ambas regiones en el ámbito de la inclusión social mediante redes de apoyo y desarrollo de capacidades; acogemos la organización de foros birregionales de gobiernos locales sobre una base bienal.

sociales.

El fortalecimiento de programas de capacitación para actores políticos y

27. Recuerde los sólidos lazos históricos y culturales que siempre han existido entre los países latinoamericanos y caribeños y las naciones de la Unión Europea, basados en el impacto positivo de los flujos de migración en ambas direcciones. Reconocemos que la pobreza es una de las causas básicas de la migración. Consideramos que es fundamental asegurar el goce y la protección efectivos de los derechos humanos para todos los migrantes. Sobre la base del principio de la responsabilidad compartida, desarrollaremos un enfoque comprensivo de la migración internacional, incluyendo la gestión ordenada de los flujos migratorios, concentrándonos en los beneficios mutuos para los países de origen y de destino, y promoviendo el reconocimiento y la toma de conciencia pública sobre la importante contribución económica, social y cultural de los migrantes a las sociedades receptoras. Subrayamos la importancia de luchar contra el racismo, la discriminación, la xenofobia y otras formas de intolerancia.

Hacemos un llamado a nuestras regiones para desarrollar aún más un diálogo comprensivo y estructurado sobre la migración, a fin de identificar nuestros desafíos comunes y áreas para la cooperación mutua. Este diálogo se beneficiará de las actividades de los Expertos ALC-UE en Migración y les brindará orientación adicional. Este marco debería permitir el intercambio de puntos de vista y la intensificación de nuestros esfuerzos hacia el incremento de la información mutua sobre los desarrollos en la política migratoria y las mejores prácticas en ambas regiones para incrementar la comprensión de las realidades de la migración. Este diálogo también abordará los temas de la migración regular e irregular, así como los vínculos entre migración y desarrollo, de conformidad con el marco legal de los países.

Intensificaremos nuestra cooperación para prevenir y combatir el tráfico ilícito de migrantes y la trata de personas, prestando apoyo a las víctimas, y promoviendo programas de retorno voluntario, digno y sostenible, facilitando a la vez el intercambio de información que contribuya a su mejor diseño y ejecución.

\section{Implementación de la Agenda de Lima sobre erradicación de la pobreza, la desigualdad y la exclusión}

28. Los diálogos políticos sectoriales de ALC-UE existentes deberán continuar y, de ser necesario, se establecerá nuevos diálogos que contribuyan a dar cumplimiento a esta Agenda, en colaboración con los organismos internacionales y de otros actores 
sociales pertinentes. En este marco, el Foro sobre Cohesión Social ha confirmado la necesidad de fortalecer aún más la asociación ALC-UE en la promoción del análisis y el intercambio de experiencias en áreas de interés común, y constituye un valioso espacio para complementar nuestras deliberaciones desde una perspectiva integral.

Antes de nuestra próxima Cumbre, estos diálogos políticos serán convocados y se preparará un informe sobre sus resultados y los avances de la Agenda de Lima.

29. Reconociendo que una parte importante de la cooperación europea actual hacia la región de ALC está concentrada en la lucha contra la pobreza, la desigualdad y en la promoción de la inclusión, garantizaremos el financiamiento adecuado para apoyar la implementación de los objetivos que surgen de las Cumbres ALC-UE

\section{DESARROLLO SOSTENIBLE: MEDIO AMBIENTE; CAMBIO CLIMATICO; ENERGIA}

30. Reiteramos la importancia de promover el desarrollo sostenible, integrando el desarrollo económico y social con la protección del medio ambiente en el marco de la democracia y el estado de derecho. Asimismo, reconocemos la erradicación de la pobreza, cambiando patrones insostenibles de producción y de consumo, y la protección y manejo de los recursos naturales, incluyendo los recursos hídricos, como objetivos centrales y requisitos esenciales para el desarrollo sostenible,

31. Estamos convencidos de que el logro del desarrollo sostenible, basado en la cooperación internacional reforzada, es una condición para el alivio de la pobreza. En este contexto, la mitigación del cambio climático y la adaptación a sus efectos, y la conservación y el uso sostenible de la biodiversidad, los recursos naturales y la energía son fundamentales para un futuro seguro para nuestros pueblos.

Para este propósito, reafirmamos el principio de las responsabilidades comunes pero diferenciadas y de las respectivas capacidades.

32. Con miras a promover el desarrollo sostenible, hacemos un llamado a una buena gobernanza medioambiental y más eficiente dentro del Sistema de las Naciones Unidas, incluyendo una estructura más integrada que se construya sobre la base de las instituciones existentes y los instrumentos internacionalmente acordados, así como el cuerpo de tratados y los organismos especializados. Nos comprometemos a participar plenamente en el proceso en curso para mejorar la Buena Gobernanza Ambiental Internacional en la Asamblea General de las Naciones Unidas. Apoyamos iniciativas para crear un consenso en las reformas.

33. Reafirmamos nuestro compromiso con los principios de Río 92 y con la plena implementación de la Agenda 21, con el Plan de Implementación de Johannesburgo, así como con los acuerdos ambientales internacionales, en particular la Convención Marco de las Naciones Unidas sobre el Cambio Climático, el Protocolo de Kioto, la Convención sobre Diversidad Biológica y la Convención de las Naciones Unidas de Lucha contra la Desertificación y Sequía. También reiteramos nuestro compromiso con la aplicación efectiva del Enfoque Estratégico para el Manejo de Sustancias 
Químicas a nivel internacional y los acuerdos ambientales multilaterales relevantes en esta materia. Creemos que existen fuertes vínculos y sinergias entre la biodiversidad y la mitigación del cambio climático, así como la adaptación.

34. Reafirmamos la importancia de nuestros esfuerzos para aumentar el apoyo mutuo entre el comercio y el medio ambiente, entre otros, mejorando el acceso al mercado para bienes medioambientales, servicios y tecnología, tomando en cuenta los impactos del comercio sobre el uso sostenible de recursos naturales, y asegurando, al mismo tiempo, que se evite las barreras innecesarias al comercio entre las dos regiones.

35. Promovemos la participación de las autoridades competentes y de todos los actores pertinentes, entre ellos la sociedad civil, en redes birregionales, regionales y subregionales para la gestión y la transferencia de conocimientos, yel intercambio de experiencias en la implementación de políticas medioambientales, el desarrollo sostenible y las mejores prácticas.

36.

Nos comprometemos a impulsar la cooperación birregional con una visión comprensiva de la temática medioambiental, centrándonos particularmente sobre el cambio climático, la desertificación, la energía, el agua, la biodiversidad, los bosques, los recursos pesqueros y el manejo de productos químicos. Estamos también comprometidos con el establecimiento y la implementación de políticas económicas que tomen en cuenta la necesidad de proteger el medio ambiente y fortalecer la inclusión social.

37. Alentaremos patrones de consumo y producción más sostenibles, procurando el uso sostenible de recursos naturales, entre otros por medio de la capacitación, la cooperación científica y tecnológica y la promoción de flujos de inversión y financiamiento, para que la protección del medio ambiente sea una realidad en ambas regiones. Para este propósito, tomaremos en cuenta las particularidades sociales, económicas, culturales y medioambientales de cada país.

Para el logro de los objetivos descritos, nos comprometemos a impulsar:

\section{La promoción de la Cooperación birregional sobre el Cambio Climático}

38. Estamos decididos a alcanzar un resultado comprensivo y globalmente acordado bajo el Plan de Acción de Bali, a más tardar en 2009, para permitir la implementación plena, efectiva y sostenida de la Convención Marco de Naciones Unidas sobre Cambio Climático (UNFCCC), a través de acciones de cooperación a largo plazo, desde ahora, hasta el 2012 y en adelante. Estamos igualmente decididos a concluir, en el mismo período, un acuerdo ambicioso y global para el Segundo Período de Cumplimiento del Protocolo de Kioto post-

2012. En este sentido, consolidaremos el diálogo ALC-UE sobre temas de cambio climático, sobre la base de las deliberaciones birregionales sostenidas en

Bali, con miras a profundizar la coordinación birregional, así como las acciones colectivas de cooperación conducentes a la COP 15 en Copenague. 
En este contexto, buscaremos facilitar iniciativas conjuntas en el área de la mitigación del cambio climático y la adaptación a sus efectos adversos, incluyendo el fortalecimiento de los mecanismos del mercado de carbono. Además nos propondremos apoyar la implementación de la Convención sobre Cambio Climático en nuestras regiones, inclusive a través de acciones apropiadas de mitigación en el contexto del desarrollo sostenible, apoyado y hecho posible por tecnología, financiamiento, y desarrollo de capacidades, de manera susceptible de ser medida, informada y verificada.

39. Estamos convencidos de que el Fondo Especial sobre Cambio Climático y el Fondo para los Países Menos Desarrollados bajo la Convención Marco de Naciones Unidas sobre Cambio Climático (UNFCCC), así como el Fondo de Adaptación del Protocolo de Kioto y la Alianza Global contra el Cambio Climático de la UE, pueden ser instrumentos para ayudar a los países en desarrollo, particularmente los Países Menos Desarrollados (PMD) y a los Pequeños Estados Insulares en Desarrollo (PEID), a incrementar su capacidad de adaptación al cambio climático, y llevar a cabo estrategias de desarrollo sostenible en apoyo al logro de los Objetivos de Desarrollo del Milenio.

40. Trabajaremos juntos para:

Promover iniciativas en nuestras regiones para prevenir, reducir y/o equilibrar las emisiones de gases de efecto invernadero, inclusive a través de mecanismos financieros de instituciones multilaterales, entre otras.

Intercambiar experiencias y profundizar el diálogo sobre políticas de desarrollo sostenible que tomen en cuenta la necesidad de crecimiento económico, protección ambiental y consolidación de la inclusión social, preparando el terreno para un crecimiento económico menos intensivo en carbono.

Reforzar las capacidades institucionales y las redes para crear sinergias entre las iniciativas regionales y nacionales existentes en el campo del cambio climático.

Proseguir los esfuerzos para fortalecer el Mecanismo de Desarrollo Limpio e incrementar la participación de ambas regiones en mecanismos de mercado flexibles, de acuerdo con las necesidades de cada país.

Promover políticas y programas, en colaboración con el sector privado y otros actores relevantes, para alentar la responsabilidad medioambiental de las empresas, junto con el desarrollo y la transferencia de tecnologías para la mitigación de y la adaptación al cambio climático, y el uso sostenible de nuestros recursos naturales existentes y de la diversidad.

Procuraremos fortalecer el régimen global del cambio climático, en el contexto de la Convención Marco de Naciones Unidas sobre Cambio Climático (UNFCCC) y el Protocolo de Kioto, para hacerlo más coherente y consistente, adoptando mecanismos apropiados e instituciones de acuerdo con sus fortalezas comparativas, asegurando mayor financiamiento y flujos de inversión para la mitigación y la adaptación, de una manera efectiva y justa.

Promover las inversiones en el campo de la producción respetuosa del medio 
ambiente y resistente al clima, e intensificar la cooperación y los esfuerzos de investigación conjunta en eco-tecnologías, entre la UE y América Latina y el Caribe, particularmente en tecnologías para la eficiencia y la energía renovable.

Incrementar la toma de conciencia acerca de las causas y los impactos potenciales del cambio climático en el crecimiento económico y la implementación exitosa de las estrategias de erradicación de la pobreza; y de las consecuencias de la inacción, a través del desarrollo de estudios de impacto económico, donde ellos aún no se estén realizando.

Mejorar el nivel de concientización, preparación, prevención y atención de los desastres naturales a través de la investigación y monitoreo climático, geológico e hidrológico, el intercambio de experiencias y la oportuna difusión de buenas prácticas, en particular en las áreas de la alerta temprana, intercambio de información, elaboración de mapas de amenazas y riesgos, y el desarrollo de capacidades locales.

Respaldar medidas orientadas a la promoción y apoyo a la adaptación de las poblaciones rurales, costeras y de montaña de América Latina y el Caribe a los impactos adversos del cambio climático sobre la biodiversidad y sus consecuencias para la economía y la seguridad alimentaria de dichas poblaciones, promoviendo el desarrollo de proyectos piloto relevantes en cada uno de estos campos tan pronto como sea posible. Promoveremos el intercambio de experiencias para mejorar el conocimiento y difundir las tecnologías de adaptación, con el propósito de lograr incrementar su efectividad.

Sobre la base de la actividad birregional existente, fortalecer la capacidad de los paìses de América Latina y el Caribe para la mitigación y adaptación a los efectos del cambio climático, incluyendo programas de cooperación en investigación sobre el impacto adverso del cambio climático; cooperación en la identificación de vulnerabilidades en los países de la región, con el propósito de reducirlas; la movilización de recursos financieros; la asistencia a las estrategias de capacitación y de respuesta; y el aporte de las experiencias locales. Se debería dar atención a los cambios en los patrones de las precipitaciones, el deshielo de los glaciares y sus consecuencias para los recursos hídricos, la mayor frecuencia e intensidad de los eventos climáticos extremos y el ascenso del nivel del mar. Todo esto, teniendo en cuenta que el calentamiento global tiene un impacto desproporcionadamente mayor en las poblaciones más pobres.

\section{Promoción de la cooperación energética birregional}

41. Somos concientes de que los desafíos del cambio climático y la cobertura de las necesidades energéticas están estrechamente vinculados al desarrollo sostenible. Es de interés común mejorar considerablemente la eficiencia energética y reducir la intensidad del uso de carbono de nuestras economías.

42. Reconocemos el principio del derecho soberano de los Estados para gestionar y regular sus recursos naturales. 
43. También reconocemos la importancia de reforzar un marco regulatorio propicio para generar y atraer la inversión.

44. En este contexto, nos comprometemos a desarrollar una cooperación energética birregional en las siguientes áreas:

Diversificación de fuentes de energía; mejor acceso a la producción y uso de energías limpias y menos intensivas en carbono; mejoramiento de los procesos de eficiencia energética; desarrollo de nuevas tecnologías; producción y uso de fuentes de energía medioambientalmente sostenibles; y mejora del uso de los servicios de energía, entre otros, en el transporte público de las grandes ciudades. También promoveremos la integración regional y las redes de interconexión como medios para reforzar la seguridad del suministro, basándose en complementariedades, y en un espíritu de solidaridad.

En el área de fuentes de energía no renovable, también cooperaremos para promover el desarrollo de nuevas tecnologías, así como la cooperación tecnológica, mejorando el acceso a servicios de energía, particularmente para los segmentos más pobres de la población.

45. Trabajaremos juntos para:

Aumentar la toma de conciencia sobre el impacto ambiental de los patrones no sostenibles del consumo de energía.

Promover mejor acceso a y el mayor uso de fuentes innovadoras de energía renovable e iniciar, para la próxima Cumbre, actividades de investigación conjunta en esta materia y sobre eficiencia energética.

Intercambiar experiencias sobre la tecnología, normas y reglamentos en materia de biocombustibles.

Promover y reforzar iniciativas orientadas a aumentar el acceso a energía menos intensiva en carbono, segura y asequible, así como la integración energética regional, a fin de mejorar las condiciones económicas, sociales y medioambientales en los países de ALC, aumentando la toma de conciencia sobre iniciativas tales como el Fondo Global para la Eficiencia Energética y las Energías Renovables (GEEREF) y otras iniciativas regionales.

Usar mecanismos existentes y alentar a las instituciones financieras multilaterales, incluyendo el GEF (Fondo Mundial para el Medio Ambiente), así como a los fondos privados, para que apoyen la investigación, innovación y desarrollo de capacidades en ambas regiones, complementando así los esfuerzos públicos. Se debería hacer esfuerzos adicionales para valerse de los proyectos de investigación de la UE relativos a la energía, financiados a través de los Programas Marco de Investigación de la UE y promover el área de conocimientos ALC-UE en este ámbito.

\section{Promoción de la sostenibilidad medioambiental}

46. Somos concientes del hecho que, junto con nuestros esfuerzos relacionados al cambio 
climático, también es importante cooperar en la respuesta, a todo nivel, a los retos de la preservación y el manejo sostenible de la biodiversidad, bosques, recursos pesqueros e hídricos, la lucha contra la desertificación y la gestión adecuada de productos químicos. Responder a estos desafíos es un componente esencial del desarrollo sostenible. Trabajaremos juntos para:

47. Fortalecer e implementar plenamente el Convenio sobre Diversidad Biológica, el cual es el instrumento primordial para la conservación de la diversidad biológica, el uso sostenible de sus componentes y el reparto justo y equitativo de los beneficios obtenidos de la utilización de los recursos genéticos. Nos esforzaremos por alcanzar un resultado ambicioso en la próxima Conferencia de las Partes (COP9 Bonn, mayo de 2008) a través de las siguientes acciones:

Trabajar para conseguir la meta sobre biodiversidad de 2010.

Colaborar para concluir antes de 2010 las negociaciones acerca de un régimen internacional sobre el acceso a los recursos genéticos y el reparto justo y equitativo de los beneficios procedentes del uso de dichos recursos.

Asegurar avances hacia el objetivo de establecer y mantener sistemas de áreas protegidas nacionales y regionales, comprensivas, eficazmente administradas y ecológicamente representativas, hacia el 2010, para las zonas terrestres, y hacia el 2012 para las zonas marítimas, de acuerdo con el Derecho Internacional.

Fortalecer los co-beneficios y sinergias entre biodiversidad y adaptación al cambio climático y medidas de mitigación.

Aumentar el apuntalamiento científico de la política de biodiversidad.

Adoptar una estrategia de movilización de recursos en la COP9.

48. Desplegar mayores esfuerzos para el manejo forestal sostenible y la adopción de políticas e incentivos para reducir la deforestación y la degradación de los bosques y la pérdida consiguiente de biodiversidad, incluyendo la movilización de recursos financieros, favoreciendo una aproximación progresiva a través de la puesta en marcha de proyectos piloto y esquemas de valoración de los servicios y productos medioambientales que proveen los bosques; tomando en cuenta las circunstancias de los países en desarrollo.

En este contexto, resaltamos la importancia de fortalecer las capacidades nacionales para mejorar el cumplimiento de la ley forestal y de promover la buena gobernanza a todos los niveles con el fin de apoyar el manejo forestal, y combatir y erradicar las prácticas ilegales, de conformidad con la legislación nacional, en materia forestal y otros sectores relacionados, así como el tráfico internacional ilícito de productos forestales, incluyendo la madera, la fauna silvestre $y$ otros recursos forestales biológicos.

49. Promover un diálogo político birregional sobre el agua y cooperar para el uso racional y sostenible de este recurso, a través de la transferencia de tecnología y el desarrollo de capacidades para una gestión eficiente de los recursos hídricos, 
incluyendo la sostenibilidad de las cuencas hidrográficas, junto con otras medidas que aseguren el acceso universal al agua potable y condiciones de saneamiento básico, tomando en cuenta nuestros compromisos con los Objetivos de Desarrollo del Milenio, el Principio 2 de la Declaración de Río sobre el Medio Ambiente y el Desarrollo, y la preservación de las zonas húmedas y sus ecosistemas. En este sentido, reconocemos la importancia de que el componente ALC de la Iniciativa de la UE para el Agua conduzca a resultados positivos.

Deberíamos intensificar el diálogo previsto por la Declaración Conjunta sobre la Implementación de la Asociación Estratégica AL-UE para los Recursos Hídricos y Saneamiento, suscrita durante el IV Foro Mundial del Agua.

50. La aplicación efectiva del Enfoque Estratégico para el Manejo de Sustancias Químicas a nivel Internacional y los instrumentos multilaterales pertinentes en la materia.

\section{Implementación de la Agenda de Lima para el Desarrollo Sostenible: Medio Ambiente; Cambio Climático; Energía.}

51. Procuraremos proseguir el diálogo ALC-UE sobre política medioambiental, con el fin de dar adecuado seguimiento a las acciones establecidas en esta Agenda, y establecer un calendario para su progresivo cumplimiento.

ALC y UE convocarán los diálogos previstos y coordinarán la preparación de un informe sobre el progreso en sus resultados, el cual se presentará a las sucesivas Cumbres.

52. Entre nuestros esfuerzos en curso para promover la cooperación birregional medioambiental con especial atención al cambio climático, sin perjuicio de las respectivas políticas nacionales, se establecerá un programa medioambiental conjunto AL-UE denominado "EUrocLIMA" en beneficio de los países de América Latina con los objetivos principales de compartir conocimiento, fomentar un diálogo estructurado y regular a todos los niveles y asegurar sinergias y coordinación de las acciones actuales y futuras en este campo.

Acogemos los estudios que se llevan a cabo en numerosos países de América Latina y el Caribe sobre el impcato económico del cambio climático, y los planes que están siendo diseñados por otros países de la región para llevar a cabo dichos estudios. Como parte de la iniciativa EUrocLIMA, consideraremos los estudios existentes y brindaremos apoyo, según sea requerido, a los países de la región que aún no lo hayan hecho para emprender nuevos estudios en esta área.

Al mismo tiempo, estamos comprometidos a:

iniciar la implementación de la recientemente emprendida Alianza Global contra el Cambio Climático de la UE, orientada a los Países Menos Desarrollados (PMD) y a los Pequeños Estados Insulares en Desarrollo (PEID), para beneficio de los países del CARIFORUM; 
asegurar que todas estas iniciativas iniciativas se apoyen entre sí y tomen en cuenta la necesidad de una transición energética, así como la complementariedad de las diversas fuentes de energía

53. Hemos decidido considerar la creación de una Fundación ALC-UE concebida como un estímulo para deliberar sobre estrategias comunes y acciones orientadas al fortalecimiento de nuestra asociación birregional, así como a aumentar su visibilidad.

Con este objetivo, se establecerá un Grupo de Trabajo birregional abierto para preparar los posibles términos de referencia de dicha Fundación. Un informe será presentado a la Reunión de Altos Funcionarios, para ser considerado en su primera reunión de 2009.

54. Acogemos con particular interés el Informe de las co-Presidencias sobre las reuniones y actividades que tuvieron lugar entre las Cumbres de Viena y de Lima sobre asuntos que forman parte de la Agenda birregional y agradecemos a los gobiernos e instituciones regionales por sus iniciativas para el seguimiento de nuestros compromisos.

55. Expresamos nuestra satisfacción por el rápido establecimiento de la Asamblea Parlamentaria Euro-Latinoamericana. Tomamos nota de las Resoluciones que ha adoptado e invitamos a las instituciones y mecanismos de integración en América Latina y Europa a colaborar estrechamente con dicha Asamblea.

56. Aceptamos con agrado la invitación de España para ser sede de la VI Cumbre ALC-UE en 2010.

57. Expresamos nuestra profunda gratitud al Gobierno y al pueblo del Perú por toda su hospitalidad y apoyo, que aseguraron la exitosa conclusión de la Cumbre de Lima 
$6^{\mathrm{a}}$ Cimeira UE ALC, Madrid, 18 de Maio de 2010

\section{DECLARAÇÃO DE MADRID}

"Para uma nova fase na parceria bi regional: a inovação e a tecnologia ao serviço do desenvolvimento sustentável e da inclusão social"

1. Nós, os Chefes de Estado e de Governo da União Europeia e da América Latina e Caraíbas, o Presidente do Conselho Europeu e o Presidente da Comissão, reunimo-nos em Madrid em 18 de Maio de 2010 a fim de reafirmarmos o nosso empenhamento em continuar a promover e a reforçar a nossa Parceria Estratégica bi-regional, baseada nos nossos princípios, valores e interesses comuns. Para o efeito, comprometemo-nos a reforçar o nosso diálogo e a nossa cooperação nos domínios prioritários que identificámos conjuntamente nas cinco cimeiras anteriores desde a Cimeira do Rio de Janeiro em 1999, atribuindo nesta Cimeira um lugar de destaque à inovação e à tecnologia para o desenvolvimento sustentável e a inclusão social.

\section{Parceirospara vencerconjuntamenteosreptosmundiais}

2. A fim de promover a paz e a segurança, a liberdade, a democracia, o Estado de direito, os direitos humanos e a prosperidade, reiteramos o nosso empenhamento no multilateralismo, principalmente no âmbito do sistema das Nações Unidas. Neste contexto, redobraremos esforços, a nível sub-regional e bi-regional, para identificar os interesses comuns e, sempre que possível, coordenar as nossas posições e acções nas organizações e instâncias multilaterais em que os nossos países são Partes. A fim de continuar a promover um sistema multilateral eficaz, continuamos dispostos a cooperar na reforma das Nações Unidas, com o objectivo de reforçar a capacidade desta organização para enfrentar os numerosos desafios colocados pelo novo milénio. Reconhecemos a necessidade de prosseguir a reforma global dos principais órgãos da ONU, nomeadamente a Assembleia Geral, o ECOSOC e o Conselho de Segurança, a fim de melhorar a representatividade, transparência e eficácia do sistema.

3. Reiteramos o nosso apoio ao desarmamento e à não-proliferação nucleares. Comprometemo-nos a prosseguir os nossos esforços conjuntos tendo em vista o êxito da

8. ${ }^{\text {a }}$ Conferência de Revisão do Tratado de Não-Proliferação das Armas Nucleares.

4. Estamos igualmente empenhados na Conferência das Nações Unidas relativa ao Tratado sobre o Comércio de Armas, que irá decorrer de forma aberta e transparente para se obter, por consenso, um tratado forte e sólido.

5. Confirmamos o nosso compromisso em relação à Declaração Universal dos Direitos do Homem, à declaração e programa de acção de Viena de 1993, bem como à promoção e protecção dos direitos humanos universais, e salientamos a nossa disponibilidade para cooperar com vista à realização do objectivo comum de atingir os mais elevados requisitos em matéria de direitos humanos. Além disso, salientamos 
o nosso desejo mútuo de alargar a nossa coordenação em instâncias como o Conselho dos Direitos do Homem em Genebra e a Terceira Comissão da AGNU em Nova Iorque.

Registamos os esforços relacionados com a moratória sobre a aplicação da pena de morte.

6. Reafirmamos o nosso empenhamento em combater a impunidade, em especial para os crimes mais graves nos termos do direito internacional, designadamente aqueles a que

se refere o Estatuto de Roma do Tribunal Penal Internacional (TPI). A sua efectiva repressão penal tem de ser assegurada através da adopção de medidas a nível nacional ou

ao nível adequado e do reforço da cooperação internacional. Convidamos os países que não são Partes no Estatuto de Roma a analisarem a possibilidade de o ratificarem ou a ele aderirem, consoante o caso. Congratulamo-nos com a próxima Conferência de Revisão do TPI, que terá lugar em Kampala, no Uganda, de 31 de Maio a 11 de Junho de 2010.

7. Reiteramos o nosso empenhamento nos objectivos e princípios consagrados na Carta das Nações Unidas. Reiteramos também a nossa decisão de apoiar todos os esforços desenvolvidos no sentido de defender a igualdade soberana de todos os Estados, de respeitar a sua integridade territorial e a sua independência política, de nos abstermos, nas nossas relações internacionais, de recorrer a ameaças ou ao uso da força, de qualquer modo que não seja coerente com os objectivos e princípios das Nações Unidas, e de apoiar a resolução de litígios por meios pacíficos e em conformidade com os princípios da justiça e do direito internacional.

Rejeitamos firmemente todas as medidas coercivas de carácter unilateral com efeito extraterritorial que sejam contrárias ao direito internacional e às regras de comércio livre geralmente aceites. Acordamos em que este tipo de prática constitui uma grave ameaça ao multilateralismo. Neste contexto, e recordando a Resolução A/RES/64/6 da AGNU, reafirmamos as nossas bem conhecidas posições sobre a aplicação das disposições extraterritoriais da Lei Helms-Burton.

8. $\quad$ Estamos determinados a intensificar a nossa cooperação para fazer face às consequências mundiais da crise económica e financeira e evitar que tais crises voltem a ocorrer, em consonância com os resultados da Conferência das Nações Unidas sobre a Crise Económica e Financeira e o seu Impacto sobre o Desenvolvimento (22-23 de Junho de 2009) e tendo também em conta os objectivos estabelecidos pelo G-20 e pelas instâncias regionais adequadas. Continuaremos a esforçar-nos por aplicar políticas macroeconômicas e financeiras destinadas a evitar futuras crises financeiras e as respectivas consequências económicas e sociais, promover um crescimento económico mundial equilibrado e sustentável, restabelecer a confiança e estabilizar os mercados financeiros mundiais. Destacamos a importância de prestar especial atenção ao impacto social e económico da crise, nomeadamente nos países em desenvolvimento, e salientamos a necessidade de reforçar o apoio às populações vulneráveis e pobres.

Neste contexto, reafirmamos o nosso empenhamento em trabalhar conjuntamente no 
sentido de uma nova arquitectura financeira internacional, nomeadamente a reforma das instituições financeiras internacionais, dando cada vez mais voz e poder de voto aos países em desenvolvimento e em transição, que estão sub-representados, sem deixar de contribuir para a introdução de reformas na governação extraquotas. Reafirmamos também o nosso empenhamento em introduzir reformas do quadro internacional de supervisão regulamentar e financeira, a fim de garantir a estabilidade e a solvabilidade dos nossos sistemas financeiros.

9. Recordamos o $30 .^{\circ}$ aniversário da adopção da Convenção sobre a Eliminação de Todas as Formas de Discriminação contra as Mulheres (CEDAW), bem como o $15 .^{\circ}$ aniversário da adopção da Declaração e da Plataforma de Acção de Pequim (Pequim + 15) e destacamos a importância da igualdade entre homens e mulheres e de reforçar o papel das mulheres, de aumentar a sua participação nas actividades políticas, sociais e económicas e de abordar o impacto negativo da crise financeira internacional no seu estatuto.

$\mathrm{Na}$ mesma linha, condenamos veementemente todos os tipos de violência de carácter sexista e reconhecemos a necessidade de tomar todas as medidas necessárias para a sua prevenção e erradicação. Reconhecemos que as questões de igualdade entre homens e mulheres têm de ser integradas em cada um dos aspectos da agenda internacional, incluindo as alterações climáticas. A este respeito, estamos empenhados em cooperar tendo em vista desenvolver um futuro diálogo.

10. Manifestamos a nossa intenção de aumentar a coerência e eficácia das nossas políticas de cooperação para o desenvolvimento, bem como de alcançar o objectivo de $0,56 \%$ em 2010 e de um rácio APD/RNB de $0,7 \%$ para a UE em 2015, tal como reflectido no Consenso de Monterrey e na Declaração da Cimeira de Viena. Os Estados--Membros que aderiram à UE depois de 2002 esforçar-se-ão por aumentar o seu rácio APD/RNB para 0,33\% até 2015. Além disso, reconhecemos a importância de trabalhar conjuntamente na reunião plenária de alto nível das Nações Unidas sobre os Objectivos de Desenvolvimento do Milénio (ODM), a realizar em Setembro de 2010, por forma a chegar a resultados orientados para a acção tendo em vista a consecução dos ODM até 2015. Reconhecemos também os progressos significativos realizados a nível regional para a consecução dos ODM.

11. Reiteramos o nosso empenhamento em conceder uma atenção especial aos países menos desenvolvidos, aos países em desenvolvimento sem litoral e aos pequenos Estados insulares em desenvolvimento.

12. Estamos empenhados em evitar o proteccionismo sob todas as suas formas. Continuamos decididos a favorecer um sistema de comércio multilateral aberto, não discriminatório e baseado em regras e a respeitar plenamente a sua disciplina, e reconhecemos o seu contributo para promover a recuperação da crise económica, bem como o crescimento e o desenvolvimento, em consonância com o princípio de um tratamento especial e diferenciado para os países em desenvolvimento, se adequado. No que respeita à agenda de negociações em curso no quadro da OMC, reiteramos o nosso compromisso de coordenar esforços para chegar a uma conclusão ambiciosa, abrangente, equilibrada e rápida da Ronda de Doha para o 
Desenvolvimento.

13. Reconhecemos o princípio do direito soberano dos Estados de gerirem e regulamentarem os seus recursos naturais. Os critérios de sustentabilidade deverão ser tidos em conta.

Consideramos que a diversificação e complementaridade da matriz energética, nomeadamente através da promoção das energias renováveis, bem como uma maior eficiência energética e uma maior poupança de energia em todos os sectores da economia, incluindo os transportes, a alteração dos actuais padrões de consumo e produção, o reforço da interconectividade regional da energia e do acesso das pessoas aos serviços de energia constituem contributos essenciais para a erradicação da pobreza e para a consecução dos Objectivos de Desenvolvimento do Milénio.

Trocaremos experiências sobre as tecnologias ligadas aos biocombustíveis, suas normas e regulamentos, bem como sobre a energia hidroeléctrica e outras formas de energia.

14. Reconhecemos o nosso interesse comum em melhorar a eficiência energética e em reduzir a intensidade das emissões de gases com efeito de estufa nas actividades de consumo e produção desenvolvidas nos nossos países, em conformidade com os compromissos internacionais existentes, por forma a enfrentar os desafios económicos, sociais, ambientais e outros colocados pelas alterações climáticas. Salientamos ainda a importância das estratégias de desenvolvimento sustentável com baixos níveis de emissão para a orientação e execução de medidas e acções de atenuação e adaptação tendo em vista o crescimento e o desenvolvimento. Em conformidade com os compromissos assumidos ao abrigo da Convenção-Quadro das Nações Unidas sobre as Alterações Climáticas (CQNUAC), reforçaremos a confiança entre as nossas regiões em matéria de alterações climáticas e intensificaremos a nossa cooperação, por forma a alcançarmos os objectivos estabelecidos.

15. Após a $15 .^{\text {a }}$ Conferência das Partes, realizada em Copenhaga, e trabalhando conjuntamente tendo em vista a 16. ${ }^{a}$ Conferência das Partes na Convenção-Quadro das Nações Unidas sobre as Alterações Climáticas (CdP 16), reconhecendo pareceres científicos sobre os limites do aumento da temperatura global e com base nos progressos até agora realizados no processo multilateral formal, através da CQNUAC e do Protocolo de Quioto, manifestamos o nosso apoio ao México para que, através de um processo de negociação transparente e inclusivo conducente a um resultado global, ambicioso, efectivo e juridicamente vinculativo destinado a reduzir e limitar as emissões de gases com efeito

de estufa, consiga a alcançar o objectivo último da CQNUAC, tendo em conta o princípio das responsabilidades comuns mas diferenciadas e das capacidades respectivas.

16. Tomamos nota de que foram organizados eventos destinados a estimular o debate sobre as alterações climáticas, como é o caso da Conferência sobre alterações climáticas realizada em Cochabamba, cujas conclusões foram transmitidas à CQNUAC, e o Diálogo para uma acção progressiva, realizado em Cartagena.

17. Estamos determinados a redobrar esforços no quadro da Convenção sobre a 
Diversidade Biológica (CDB) para a conservação e a utilização sustentável da biodiversidade e continuaremos a procurar reduzir significativamente a perda de biodiversidade, tendo presentes os ODM e o contributo da biodiversidade para a erradicação da pobreza. Estamos decididos a trabalhar para a adopção de um Plano Estratégico eficaz e orientado para o período pós-2010, que inclua objectivos mensuráveis, exequíveis e realistas, na 10. ${ }^{a}$ Conferência das Partes na CDB (CdP 10). Reiteramos também o nosso empenhamento em concluir com êxito as negociações sobre um regime jurídico internacional de acesso aos recursos genéticos e partilha dos benefícios (APB) na CdP 10. Aguardamos com expectativa a obtenção de um acordo quanto ao estabelecimento de uma Plataforma Intergovernamental sobre a Biodiversidade e os Serviços Ecossistémicos (IPBES) na terceira e última reunião ad hoc a realizar em Busan, na República da Coreia, em Junho de 2010.

18. Estamos determinados a contribuir positivamente para o lançamento do Comité de Negociação Intergovernamental do PNUA mandatado para desenvolver um instrumento juridicamente vinculativo sobre o mercúrio, cuja primeira sessão se realizará em Estocolmo, de 7 a 11 de Junho de 2010.

19. Reafirmamos que todas as culturas têm o direito de existir e de preservar o seu próprio património cultural. Neste contexto, o diálogo intercultural deverá fomentar o entendimento mútuo, salvaguardar a diversidade e a identidade cultural, promovendo simultaneamente o desenvolvimento de indústrias culturais.

20. Deveremos intensificar a nossa cooperação no que se refere aos desafios colocados pelo terrorismo, pela criminalidade transnacional organizada, pela corrupção, pelo tráfico de armas e munições, pelo problema mundial da droga, pelo tráfico de armas relacionado com a droga, pelo branqueamento de capitais, pelo tráfico de pessoas, especialmente mulheres e crianças, e pelo contrabando de migrantes.

Manifestamos a nossa preocupação com o aumento dos actos de violência relacionada, em certos casos, com organizações criminosas envolvidas no tráfico de drogas ilícitas, e apelamos a que sejam tomadas medidas que impeçam essas organizações de adquirir os meios que lhes permitem desenvolver actividades susceptíveis de afectar tanto a sociedade civil como as autoridades responsáveis pela aplicação da lei.

Rejeitamos firmemente o terrorismo, sob todas as suas formas e manifestações, e reafirmamos que, qualquer que seja a sua origem ou motivação, não tem qualquer justificação. Reiteramos também o nosso empenhamento em prevenir, combater e eliminar o terrorismo e o seu financiamento através da mais ampla cooperação.

A nossa cooperação na luta contra todos estes desafios será estabelecida no pleno respeito pelos direitos humanos e pelo Estado de direito e em conformidade com o direito internacional.

21. Apoiamos a cooperação em matéria de paz e segurança, tendo em vista reforçar o papel da ONU neste domínio, nomeadamente a prevenção de conflitos e a gestão de crises. Desenvolveremos o nosso diálogo bi-regional neste domínio. 


\section{ReforcaranossaParceriaEstratégicabi-regional}

22. Congratulamo-nos com os progressos realizados no âmbito da nossa Parceria Estratégica. Comprometemo-nos a reforçar mais ainda essa parceria, a fim de aprofundar o diálogo político e a integração regional, promover a inclusão e a coesão sociais e intensificar as relações bilaterais entre os países das duas regiões.

23. Em especial, manifestamos a nossa satisfação com os seguintes desenvolvimentos:

- UE-Colômbia e Peru: conclusão das negociações de um Acordo Comercial com Múltiplas Partes ${ }^{1}$.

- UE-América Central: conclusão das negociações de um Acordo de Associação.

- UE-CARIFORUM: diálogo político renovado a nível regional, lançado em 23 de Março de 2010, em Kingston, Jamaica, e os progressos para o estabelecimento de uma nova Estratégia Conjunta UE-Caraíbas.

- $\quad 3 .{ }^{a}$ Cimeira UE-Brasil no âmbito da Parceria Estratégica UE-Brasil

1 A Bolívia observou este acordo e apresentou uma queixa ao Tribunal de Justiça da Comunidade Andina

5. ${ }^{\mathrm{a}}$ Cimeira UE-México e adopção de um plano executivo conjunto, no âmbito da Parceria Estratégica UE-México

- $\quad$ 4. ${ }^{a}$ Cimeira UE-Chile e estabelecimento da Associação UE-Chile para o Desenvolvimento e a Inovação (ADI).

24. Negociações UE-MERCOSUR: recordamos a importância das negociações recentemente retomadas com vista a alcançar um Acordo de Associação ambicioso e equilibrado entre as duas regiões.

25. Manifestamos a nossa satisfação com a decisão tomada pelos Chefes de Estado e de Governo da América Latina e Caraíbas de criar a Comunidade de Estados da América Latina e Caraíbas, como primeiro mandato da Declaração Presidencial da "Cimeira da Unidade da América Latina e Caraíbas", realizada em Cancun a 23 de Fevereiro de 2010. Manifestamos também o nosso apoio à República Bolivariana da Venezuela e à República do Chile nas suas tarefas de, respectivamente, organizarem a Cimeira da Comunidade da América Latina e Caraíbas (CALC) e da Cimeira do Grupo do Rio, em 5 de Julho de 2011 na Venezuela e em 2012 no Chile, que têm como compromisso realizar verdadeiros passos rumo à consolidação da Comunidade de Estados da América Latina e Caraíbas.

26. Reiteramos o nosso compromisso de contribuir, a longo prazo e em toda a medida do possível, para os esforços conjuntos empreendidos a favor do povo do Haiti e para a recuperação e reconstrução do país e suas instituições, de acordo com as prioridades e as necessidades mais fundamentais da população e do governo do Haiti. Manifestamos a nossa convicção de que a recente catástrofe natural deve não 
só transformar-se em oportunidades de "reconstruir melhor", como impulsionar a realização de progressos económicos e sociais a nível global, em conformidade com o plano de acção interno para a recuperação e o desenvolvimento nacionais. Neste contexto, esperamos que a Conferência de São Domingos, que terá lugar a 2 de Junho de 2010, seja bem sucedida.

27. Manifestamos também a nossa intenção de reforçar a cooperação para a prevenção das catástrofes naturais e a gestão dos seus efeitos. Reconhecemos a importância das redes e infra-estruturas de TIC em situações de catástrofes naturais como instrumentos de prevenção e gestão dessas catástrofes.

28. Na sequência dos compromissos que assumimos em Lima em 2008, regozijamo-nos com o lançamento, em 30 de Junho de 2009, do Diálogo Estruturado e Exaustivo UE-ALC sobre as Migrações e apoiamos os princípios e a aplicação integral da sua agenda, tal como aprovada no documento intitulado "Bases para estruturar o diálogo UE-ALC sobre migrações", adoptado nessa ocasião. Através de uma abordagem multidimensional, esse Diálogo visa alcançar um melhor entendimento das realidades das migrações e promover a fruição e a protecção efectivas dos direitos humanos para todos os migrantes nas duas regiões, bem como identificar os desafios e os domínios de interesse mútuo que exigem soluções comuns e uma cooperação concreta orientada para os resultados sobre questões específicas, tais como as referidas no nosso Plano de Acção.

No contexto do nosso Diálogo, deveremos também abordar medidas para lutar contra o tráfico de seres humanos e o contrabando de migrantes, e para dar assistência às vítimas. Manifestamos igualmente a nossa preocupação com todas as práticas baseadas na intolerância e no preconceito racial.

29. A parceria estratégica UE-ALC deverá assumir um papel crucial nas futuras negociações sobre alterações climáticas e biodiversidade, e, neste contexto, iniciámos um Diálogo UE-ALC sobre as Alterações Climáticas e o Ambiente com base nos compromissos pertinentes da "Agenda de Lima para o Desenvolvimento Sustentável: Ambiente, Alterações Climáticas e Energia", bem como sobre a biodiversidade, que nos propomos cumprir. No quadro do Diálogo, foi salientada a importância de se avançar na execução da Agenda de Lima, pelo que manifestamos o nosso apoio político à exploração de iniciativas inovadoras a este respeito.

30. Estamos empenhados em promover estratégias integradas bem como políticas públicas - incluindo políticas orçamentais e de protecção social - que visem erradicar a pobreza e reduzir a desigualdade e a exclusão social. Encorajamos o acesso dos jovens a empregos decentes, dignos e produtivos e apelamos a que sejam assegurados sistemas de ensino e formação profissional que respondam às necessidades do mercado de trabalho e dos objectivos de desenvolvimento, e a que seja abordada a questão do desemprego de longa duração, e a sua prevenção.

31. Congratulamo-nos com o papel activo desempenhado pelo Comité Económico

e

Social Europeu (CESE) e pelos seus homólogos da América Latina e das Caraíbas. 
32. Intensificaremos a nossa actual cooperação bi-regional a fim de abordar o problema mundial da droga, em conformidade com o princípio da responsabilidade comum e partilhada. Neste contexto, congratulamo-nos com a Declaração de Madrid adoptada na

12. ${ }^{a}$ Reunião de Alto Nível do Mecanismo de Coordenação e Cooperação em matéria de

Droga ALC-UE, realizada em Madrid, em 26 e 27 de Abril de 2010.

33. Congratulamo-nos com a criação pela UE de uma nova Facilidade de Investimento para a América Latina (FIAL), cujo principal objectivo é exercer um efeito de alavanca a fim de mobilizar financiamentos suplementares para apoiar o investimento na América Latina, que deverão contribuir para o progresso nos domínios prioritários. Ao mesmo tempo, aguardamos com expectativa a criação do Fundo para as Infra-estruturas das Caraíbas. Estas iniciativas irão aumentar a capacidade para financiar projectos em sectores fundamentais na América Latina e nas Caraíbas.

34. Para além da iniciativa adoptada na Cimeira de Lima, decidimos criar uma Fundação UE-ALC, cujo mandato recebemos. Essa Fundação é concebida como um instrumento útil para reforçar a nossa parceria bi-regional e um meio de lançar o debate sobre estratégias e acções comuns e de aumentar a sua visibilidade. A decisão sobre a sede da Fundação será adoptada pelos altos funcionários.

35. Tomamos nota das resoluções da Assembleia Parlamentar Euro-LatinoAmericana (Eurolat) e convidamo-la a continuar a intensificar as suas acções em benefício de ambas as regiões.

36. Congratulamo-nos com as reuniões e actividades efectuadas entre as Cimeiras de Lima e de Madrid, bem como com as suas contribuições relativamente a questões que fazem parte da agenda bi-regional, e bem assim com todas as iniciativas destinadas a dar seguimento aos nossos compromissos. Agradecemos a todos os países da UE e da ALC que acolheram e apoiaram essas reuniões.

37. Procuramos obter resultados concretos e um maior valor acrescentado no nosso diálogo bi-regional, alargando-o a novos domínios de interesse comum, como previsto no Plano de Acção Comum que hoje adoptamos. Este Plano de Acção visa principalmente conceber programas e iniciativas de cooperação bi-regional, nomeadamente a cooperação sul-sul e a cooperação triangular. Nele se inclui a identificação de domínios prioritários para futuros trabalhos, nomeadamente sectores tais como a ciência, investigação, inovação e tecnologia, o desenvolvimento sustentável, o ambiente, as alterações climáticas, a biodiversidade, a energia, a integração regional e a interconectividade para promover a inclusão e coesão sociais, as migrações, a educação e o emprego para promover a inclusão e coesão sociais, bem como o problema mundial da droga.

III. Promoverainovacão e atecnologia à escalabi-regionaltendo emvistao desenvolvimento sustentável eainclusão social

38. Cientes do papel fundamental desempenhado pela ciência, tecnologia e 
inovação para a consecução do desenvolvimento sustentável e da inclusão social, através da apropriação do conhecimento pela sociedade, bem como dos benefícios mútuos proporcionados pela cooperação no reforço das capacidades, pelos programas de investigação e pelas actividades de transferência de tecnologias, graças à criação de redes temáticas de reforço da inovação, ao aumento da competitividade, ao fomento da independência da ciência e da tecnologia e à promoção de uma maior utilização destas na América Latina, nas Caraíbas e na UE, acordamos em dar prioridade à cooperação bi-regional e triangular, bem como às actividades nestes domínios, especialmente para permitir o acesso às oportunidades de cooperação por parte dos países com pouca ou nenhuma participação nos programas europeus.

39. Decidimos igualmente reforçar o diálogo sobre ciência, tecnologia e inovação a nível ministerial e de altos funcionários da UE e da ALC competentes em matéria de C\&T, a fim de assegurar a actualização e o acompanhamento das prioridades e instrumentos conjuntos, tendo em conta os interesses e as diferenças existentes entre as regiões e dentro de cada região, por forma a reforçar o ambiente propício à inovação social e tecnológica nas nossas sociedades.

40. Totalmente empenhados nas prioridades estabelecidas e nas decisões adoptadas nas anteriores Cimeiras UE-ALC para a realização de um "Espaço do Conhecimento UE-ALC", acordamos em desenvolver e implementar a Iniciativa Conjunta UE-ALC para a Investigação e a Inovação ("Iniciativa") adoptada no Fórum ministerial UE-ALC da Ciência e da Tecnologia, realizado em Madrid em 14 de Maio de 2010. A Iniciativa baseia--se numa série de acções, já existentes ou novas, que combinam diferentes tipos de instrumentos a nível nacional, regional e bi-regional, conforme adequado, de forma complementar e sinérgica, tendo em vista atingir os objectivos da Iniciativa. A Iniciativa prevê a cooperação científica e tecnológica em estreita coordenação com acções no domínio do ensino superior e da inovação. Prevêse que isso crie condições para o reforço da interface entre a investigação e a inovação e facilite a transferência e adaptação de tecnologias em formatos acessíveis às micro-empresas e às PME, nomeadamente através de uma rede de centros de conhecimento e inovação, da participação no Programa-Quadro Europeu de Investigação, da progressiva abertura dos programas nacionais de investigação, da interconectividade entre as infra-estruturas de investigação e da promoção da cooperação no reforço de capacidades humanas e institucionais.

41. Tendo em vista a prossecução destes objectivos, o referido Plano de Acção Conjunto relativo à investigação, tecnologia e inovação inclui a aplicação da Iniciativa Conjunta para a Investigação e a Inovação bem como outras actividades bi-regionais em matéria de Investigação e Desenvolvimento e de Inovação.

42. Congratulamo-nos vivamente com a realização da $7 .{ }^{a}$ Cimeira UE-ALC no Chile em 2012 e é com prazer que aceitamos o convite para nela participar.

43. Agradecemos a Espanha e à cidade de Madrid por terem acolhido a $6 .{ }^{\mathrm{a}}$ Cimeira UE-ALC. 